UNIVERSIDADE DE SÃO PAULO

FACULDADE DE FILOSOFIA, LETRAS E CIÊNCIAS HUMANAS

NÚCLEO DE ESTUDO DAS DIVERSIDADES, INTOLERÂNCIAS E CONFLITOS

PROGRAMA DE PÓS-GRADUAÇÃO EM HUMANIDADES, DIREITOS E

OUTRAS LEGITIMIDADES

\title{
A forma flutuante \\ Desejo e doutrina nos filmes do Terceiro Reich
}

Versão corrigida

HUGO NOGUEIRA NETO

Dissertação apresentada ao Programa Interdisciplinar de PósGraduação em Humanidades, Direitos e Outras Legitimidades do Núcleo de Estudos das Diversidades, Intolerâncias e Conflitos (DIVERSITAS) da Faculdade de Filosofia, Letras e Ciências Sociais para a obtenção o título de Mestre em Ciências.

Orientador: Prof. Dr. Maurício Cardoso

São Paulo 
Autorizo a reprodução e divulgação total ou parcial deste trabalho, por qualquer meio convencional ou eletrônico, para fins de estudo e pesquisa, desde que citada a fonte.

Catalogação na Publicação

Serviço de Biblioteca e Documentação

Faculdade de Filosofia, Letras e Ciências Humanas da Universidade de São Paulo

N778f Nogueira Neto, Hugo A forma flutuante: desejo e doutrina nos filmes do Terceiro Reich / Hugo

Nogueira Neto ; orientador Maurício Cardoso. - São Paulo, 2017.

$308 \mathrm{f}$.

Dissertação (Mestrado) - Programa de Pós-Graduação

Humanidades, Direitos e Outras Legitimidades da

Universidade de São Paulo. Área de concentração: Humanidades, Direitos e Outras Legitimidades.

1. CINEMA CLÁSSICO. 2. NAZISMO. 3. PSICANÁLISE.

4. ANTISSEMITISMO . 5. SEGUNDA GUERRA MUNDIAL (1939-

1945). I. Cardoso, Maurício, orient. II. Título. 
NOGUEIRA NETO, Hugo. A forma flutuante: desejo e doutrina nos filmes do

Terceiro Reich. Dissertação apresentada à Faculdade de Filosofia, Letras e Ciências

Humanas da Universidade de São Paulo para obtenção do título de Mestre em Ciências.

Aprovado em:

Banca Examinadora

Prof. Dr.

Instituição:

Julgamento:

Assinatura:

Prof. Dr.

Instituição:

Julgamento:

Assinatura:

Prof. Dr.

Instituição:

Julgamento:

Assinatura:

Prof. Dr.

Instituição:

Julgamento:

Assinatura: 

Do insight incial à forma realizada, este trabalho contou com os benefícios e os proventos da extraordinária e fecunda generosidade de Maria Cristina Sodatti, Mara Selaibe e Maurício Cardoso, aos quais dedico todos meus votos de gratidão e reconhecimento 

"Nada falta ao desejo, não lhe falta seu objeto" Gilles Deleuze, Felix Guattari 



\section{Resumo}

NOGUEIRA NETO, Hugo. A forma flutuante: desejo e doutrina nos filmes do

Terceiro Reich. 2017. 308 pgs. Dissertação (Mestrado). Faculdade de Filosofia, Letras e Ciências Humanas, Universidade de São Paulo. São Paulo, 2017.

Mediante o cotejo interdisciplinar entre a crítica historiográfica, a análise fílmica e a interpretação psicanalítica nas linhas freudiana e lacaniana, essa pesquisa investigou quatro obras cinematográficas comissionadas pelo governo nazista durante a Segunda Guerra Mundial com a finalidade de promoção de suas políticas raciais e de gênero: Jud Süß (1940), Die große Liebe (1942), Münchhausen (1943) e Titanic (1943). A partir dessas produções, o estudo perscrutou os sistemas de justaposição de fantasias socialmente partilhadas aos denominadores ideológicos do nacional-socialismo. Identificou, igualmente, os processos de negociação entre as instâncias da indústria cultural e as agências governamentais para alinhar o desejo e a doutrina na forma flutuante da fantasia cinematográfica.

Palavras Chaves: Cinema, Nazismo, Psicanálise, Antissemitismo, Segunda Guerra Mundial, Indústria Cultural. 


\begin{abstract}
NOGUEIRA NETO, Hugo. The Floating Form: Desire and Doctrine in the Films of the Third Reich. 2017. 308 pgs. Dissertação (Mestrado). Faculdade de Filosofia, Letras e Ciências Humanas, Universidade de São Paulo. São Paulo, 2017.

Making use of instruments pertaining to the domain of historical criticism, filmic analysis and psychoanalytic theory under Freudian and Lacanian guidelines, this research investigated four cinematographic works commissioned by the Nazi government during World War II aimed to promoting its racial and gender policies: Jud Süß (1940), Die große Liebe (1942), Münchhausen (1943) and Titanic (1943). Through these films, the analysis examined the systems of juxtaposition between socially shared fantasies and the ideological denominators of National Socialism. The research identified also the schemes of negotiation between instances of cultural industry and government agencies in order to align desire and doctrine in the floating form of film fantasy.
\end{abstract}

Keywords: Cinema, Nazism, Psychoanalysis, Antisemitism, World War II, Cultural Industry. 


\section{$\underline{\text { Lista de siglas e termos em alemão }}$}

BdK - Bund für deutsche Kirche: Liga para a Igreja alemã, organização unificada das denominações protestantes menores.

BdM - Bund deutscher Mädel: "Liga das Moças Alemãs"

Bekennende Kirche: Igreja Confessional, corrente que congregava os setores conservadores do protestantismo alemão.

Bergfilm - "Filme alpino": gênero cinematográfico especificamente alemão que tomava a escalada de uma montanha como assunto central das tramas.

Bildungsroman - "Romance de formação": modalidade literária, típica da segunda metade do século XVIII na qual se apresenta a formação do caráter de um personagem pelas suas experiências de vida, suas viagens e seu subsequente retorno ao lar.

Blitzkrieg: "Guerra relâmpago" - tática militar alemã de ataques rápidos que caracterizou a primeira fase da expansão do exército nazista sobre a Europa.

Blut und Boden - "Sangue e Solo" - os denominadores centrais da noção de identidade nacional cultivada durante o nazismo.

DFO -Deutscher Frauen Orden Rotes Haken Kreuz: "Ordem das Mulheres Alemãs da Vermelha Cruz Gamada"

Doppelgänger - "Sósia": um desdobramento da imagem de uma pessoa, pelo que o termo encontrou ressonância nos estudos das alucinações psicóticas e também em representações do cinema expressionista alemão.

Durchhaltliede - "canções de perseverança": modalidade de propaganda pela qual o nazismo propugnava o otimismo cego frente à desesperante conjuntura da guerra.

Filmliebling - "Favorito das telas".

Filmstern - "Estrela de cinema".

Freikorps - "Associação Livre": nomenclatura genérica dos grupos paramilitares que se opuseram ao Tratado de Versalhes e à instituição da República de Weimar pela prática sistemática de atentados e ações terroristas.

Führerprinzip - "princípio de liderança": o princípio de obediência incondicional a Hitler Geniusfilm - "Filme de gênio" - linha de filmes biográficos que retratavam as vidas e os feitos de grandes personalidades do passado, em especial o Rei da Prússia, Frederico II.

Gestalt - "Forma" - termo difusamente aplicado aos sistemas teóricos nas áreas da literatura e da psicanálise que abordam a relação de semelhança entre o conjunto e suas partes.

Heimat - "pátria", "lar". 

Heimatfilm - "Filme da patria" - gênero cinematográfico alemão relacionado aos aspectos da vida social e cultural nas regiões campestres e alpinas, que, na época nazista, passou também a incluir obras que tematizavam o retorno de emigrados à Alemanha.

HJ - Hitlerjugen: "Juventude Hitlerista".

Judenbann - "interdito aos judeus".

Judengasse - "rua de judeus".

Kampfzeitfilme - "filmes da época da luta": obras cinematográficas realizadas nos anos iniciais do regime fascista, ambientadas durante a República de Weimar, que retratavam o despertar da consciência de um protonazista e a fundação do Partido nos turbulentos anos de luta entre ultranacionalistas e comunistas.

Kultur - "Cultura": na teoria política alemã, domínio referente às práticas sociais nos campos da religião, da ciência, da filosofia e das artes.

Kulturprotestantismus - "Protestantismo cultural": corrente que abrangia os setores liberais do protestantismo alemão.

Luftwaffe - "Aeronáutica".

Maschinenmenschen - "máquinas humanas", androides.

Mutterkreuz - "Cruz de Mãe": condecoração conferida pelo Terceiro Reich às mulheres que houvessem partejado ao menos quatro filhos.

Muttertag - "Dia das mães": uma data comemorativa instituída pelo regime nazista para promover a maternidade como o mais importante papel social das mulheres.

Neue Sachlichket - "Nova Objetividade": movimento artístico alemão do final do período weimariano que se contrapunha ao Expressionismo pelo corte realista dos temas, o tratamento violento das formas e a preocupação com a perspectiva social.

NSDAP - Nationalsozialistische Deutsche Arbeiterpartei: Partido Nacional Socialista dos Trabalhadores Alemães.

NS-Frauenschaft - "Organização das Mulheres Nacional-socialistas".

OKW - Oberkommando der Wehrmacht: "Comando Superior das Forças Armadas".

Persönlichkeit - "personalidade": noção que, na doutrina nazista implicava nos atributos da excelência racial da qual emanavam as melhores qualidades da coletividade. O conceito de personalidade, oriundo do Romantismo alemão, imputava ao artista a tarefa de desvelar o real. Tratava-se de uma ideia que os críticos fascistas procuraram revivescer contra a falência do individualismo burguês.

PK - Propaganda Kompanien: "Companhias de Propaganda": unidades jornalísticas responsáveis pela cobertura audiovisual das ações militares indicadas pelo RMPV, mas sob comando do OKW. 

Prädikat - "Predicado": condecoração cinematográfica instituída pelo regime para fixar a relevância política de cada filme que, dependendo de seu ranking, dispunha das facilidades oferecidas pelo Estado na distribuição e de acesso privilegiado às salas de exibição.

Realpolitik - "Política realista": perspectiva das ciências políticas voltadas para a prevalência das hierarquias de poder sobre os propósitos idealistas nas relações entre os Estados.

Reichstag - "Parlamento".

RFK - Reichsfilmkammer: "Câmara de Filmes do Reich".

RM - Reichsmark: moeda oficial da Alemanha de 1924 até 1948.

RMVP - Reichsministerium für Volksaufklärung und Propaganda: "Ministério do Reich para Esclarecimento Popular e Propaganda".

SA - Sturmabteilung: "Divisão tempestade", ala paramilitar do Partido Nazista.

Schultze Polizei: Polícia de proteção.

SD -"Serviço de Segurança" - central de inteligência vinculada à SS.

SS - Schutzstaffe: "Tropa de Proteção".

Staatsauftragfilm - "Filme comissionada pelo Estado".

Staatswichtig - "relevante ao Estado".

Stukas: aeronaves de bombardeio da Luftwaffe.

Systemzeit- "Época do sistema": termo pejorativo pelo qual os nazistas se referiam ao período weimariano.

Überkonfessionalismus - "supraconfessionalismo": orientação religiosa preconizada pelo nazismo baseada em valores genéricos do cristianismo sem a segmentação da fé nos credos católico e protestante.

UFA - Universum Film Aktien Gesellschaft - rede de estúdios mais influente durante o período weimariano e o Terceiro Reich.

Unterhaltungsfilm: filme de entretenimento sem conteúdos políticos manifestos.

Untermensch: "sub-humano" - denominador aplicado aos sujeitos considerados como racialmente inferiores aos arianos, notadamente os judeus.

Volk: "Povo".

Volksturm: "Tempestade do povo": campanha derradeira de recrutamento de homens para a guerra que conscreveu enfermos, idosos e adolescentes.

Wehrmacht: "Forças Armadas".

Wochenschau: "Mostra Semanal" - título dos cinejornais exibidos semanalmente antes dos longas-metragens ficcionais nas salas de cinema do período nazista.

Wunderwaffe: "arma miraculosa", um dispositivo que, segundo a propaganda fascista fazia crer, vinha sendo testada laboratorialmente para reverter a guerra a favor dos alemães. 

Zeitgeist: "Espírito da época".

Zivilization: "Civilização - na teoria social alemã, o espaço das relações políticas e da diplomacia. 



\section{$\underline{\text { Lista de imagens }}$}

Página 49: figuras 1.1, 1.2, 1.3: Heinrich George, Eugen Klöpfer, Kristina Söderbaum, e Werner Krauß em fotogramas do filme Jud Süß (direção: Veit Harlan; direção de fotografia: Bruno Mondi/Terra Kunstfilm, 1940).

Página 64: figuras 1.4, 1.5, 1.6, 1.7 e 1.8: Malte Jäger em fotogramas do filme Jud Sü $\beta$ (direção: Veit Harlan; direção de fotografia: Bruno Mondi/Terra Filmkunst, 1940).

Página 75: figuras 1.9 e 1.10, 1.11, 1.12 e 1.13: Ferdinand Marian, Kristina Söderbaum e Malte Jäger em fotogramas do filme $J u d$ Süß (direção: Veit Harlan; direção de fotografia: Bruno Mondi) /Terra Filmkunst, 1940.

Página 103: figuras 1.14 e 1.15: Malte Jäger e Kristina Söderbaum em fotogramas do filme Jud Süß (direção: Veit Harlan; direção de fotografia: Bruno Mondi/Terra Filmkunst, 1940).

Página 135: figuras 2.1, 2.2 e 2.3: Zarah Leander em fotogramas do filme Die große Liebe (direção: Rolf Hansen; direção de fotografia: Hans Theyer/UFA, 1942).

Página 138: figuras 2.4 e 2.5: Viktor Staal e Zarah Leander em fotogramas do filme Die große Liebe (direção: Rolf Hansen; direção de fotografia: Hans Theyer/UFA, 1942).

Página 142: figuras 2.6, 2.7 e 2.8: fotogramas do filme Die große Liebe (direção: Rolf Hansen; direção de fotografia: Hans Theyer/UFA, 1942).

Página 150: figuras 2.9 e 2.10: fotogramas do filme Die große Liebe (direção: Rolf Hansen; direção de fotografia: Hans Theyer/UFA, 1942).

Página 166: figura 3.1: Hans Albers e Ferdinand Marian em fotograma do filme Münchhausen (direção: Josef von Baky; direção de fotografia: Konstantin Irmen-Tschet e Werner Krien/UFA, 1943).

Página 194: figuras 3.2 e 3.3: Michael Bohnen e Hans Albers em fotogramas do filme Münchhausen (direção: Josef von Baky; direção de fotografia: Konstantin Irmen-Tschet e Werner Krien/UFA, 1943).

Página 197: figuras 3.4 e 3.5: Ilse Werner e Marianne Simson em fotogramas do filme Münchhausen (direção: Josef von Baky; direção de fotografia: Konstantin Irmen-Tschet e Werner Krien/UFA 1943).

Página 205: figuras 3.6 e 3.7: Leo Slezak e Brigitte Horney em fotogramas do filme Münchhausen (direção: Josef von Baky; direção de fotografia: Konstantin Irmen-Tschet e Werner Krien/UFA,1943).

Página 206: figura 3.8: Hans Albers e Marianne Simson em fotograma do filme Münchhausen (direção: Josef von Báky; direção de fotografia: Konstantin Irmen-Tschet e Werner Krien/UFA, 1943). 

Página 229: figuras 4.1, 4.2 e 4.3: Sybille Schmitz, Ernst Fürbringer, Kirsten Heiberg e Jolly Bohnert em fotogramas do filme Titanic (direção: Herbert Selpin/Werner Klingler; direção de fotografia: Friedl Behn-Grund/Tobis Filmkunst, 1943).

Página 234: figuras 4.4, 4.5, 4.6 e 4.7: Kirsten Heiberg, Charlotte Thiele, Karl Schönböck e Ernst Fürbringer em fotogramas do filme Titanic (direção: Herbert Selpin/Werner Klingler; direção de fotografia: Friedl Behn-Grund/Tobis Filmkunst, 1943).

Página 245: figuras 4.8: Sybille Schmitz em fotograma do filme Titanic (direção: Herbert Selpin/Werner Klingler; direção de fotografia: Friedl Behn-Grund/Tobis Filmkunst, 1943).

Página 259: figuras 4.9 e 4.10: Hans Nielsen e Sybille Schmitz em fotogramas do filme Titanic (direção: Herbert Selpin/Werner Klingler; direção de fotografia: Friedl BehnGrund/Tobis Filmkunst, 1943).

Página 273: figura 5.1: fotograma do filme Kolberg (direção: Veit Harlan: direção de fotografia: Bruno Mondi/UFA, 1945). 



\section{$\underline{\text { Sumário }}$}

Introdução

Capítulo 1 - Judeu Süss 39

Capítulo 2 - O grande amor 105

Capítulo 3 - Münchhausen 159

Capítulo 4 - Titanic .211

Conclusão 269

Filmografia .289

Créditos de Imagens 292

Referências bibliográficas 293

Índice onomástico 303 



\section{Introdução}

O Terceiro Reich sobreviveu uma semana após o suicídio de seu mentor no último dia de abril de 1945. O almirante Karl Dönitz, nomeado por Hitler como seu sucessor, assinou a rendição em 7 de maio. Na madrugada entre os dias 8 e 9, a guerra se encerrou em todo território europeu. Até ali, ela havia consumido 5 anos, 8 meses e 7 dias, eliminou sessenta milhões de vidas e produziu uma invariável paisagem de cidades arrasadas, rescendendo à putrescência dos cadáveres dissolvendo sob os entulhos ao sol da primavera ${ }^{1}$. Em poucos meses, o Terceiro Reich desaparecera completamente, deixando para trás um impressionante espólio documental para atestar suas posições, ideias, gestos e expectativas. Entre esses despojos avultava um compêndio de 1350 filmes cinematográficos, um material incrivelmente diversificado de uma experiência política e social sem precedentes na História contemporânea.

Em meio a uma profusão de celebrações, paradas e comícios, o Estado nazista no seu apogeu constituiu o que Eric Rentschler qualificou como um "sustentado evento cinematográfico" 2 . Ao lado da política, o cinema viria a ser, por isso, uma das dimensões sociais que mais recebeu atenção dos historiadores do nazismo ${ }^{3}$. O retrato derivado das obras cinematográficas, contudo, ofereceu aos pesquisadores uma desconcertante imagem de seu ambiente social, cultural e político. De 1933 a 1945, os Unterhaltungsfilme (filmes de entretenimento, sem conteúdos políticos) dominaram ostensivamente a cena. Dos 1350 filmes

\footnotetext{
1 SHIRER, William L. The Rise and Fall of the Third Reich: a History of Nazi Germany. Nova York: Simon\&Schuster, 2011, 1139-1140.

${ }^{2}$ Desde seu advento, sugeriu Rentschler, o nazismo chegou ao seu público como um monumental espetáculo midiático. Seus grandes momentos - os discursos do Führer, os colossais comícios do Partido, os jogos de Berlim, as campanhas militares, a eclosão da guerra, os trabalhos do genocídio e a derrocada do regime foram cuidadosamente preservados em película. A paixão pelo registro audiovisual acompanhou integralmente o destino do regime. De Hitler e Goebbels, apontou Rentschler, pode-se afirmar que foram, portanto, os grandes meteurs en scène do século XX. Melhor do que qualquer outro ditador, ambos lançaram mão dos mais avançados meios tecnológicos para produzir um sistema de poder sustentado na dimensão imaginária da plataforma audiovisual. RENTSCHLER, Eric. The Ministry of Illusion: Nazi Cinema and its After Life. Cambridge: Harvard University Press, 2002, 1.

${ }^{3}$ SCHOEPS, Karl-Heinz. Literature and Film in the Third Reich. Tradução: Kathleen M. Dell'Oro. Rochester, Nova York: Camdem House, 2013, 205-6.
} 
oriundos da Alemanha nazista, 1200 destinaram-se ao entretenimento com variados níveis de esclarecimento político. Entre os 1094 longas-metragens ficcionais, 941 foram filmes de gênero: 295 constituíam melodramas e biopics (filmes biográficos romantizados, ambientados em meio a grandes acontecimentos históricos), 123 eram filmes de mistério e 423, comédias e musicais. Apenas 153 deles terminaram indexados pelos Aliados como obras de propaganda 4 .

$\mathrm{Na}$ Alemanha, mesmo antes do nazismo, o cinema havia realizado uma experiência social ímpar. Nivelando sua audiência numa sociedade igualitária de espectadores, a qual atravessava as diferenças sociais e as distâncias geográficas, ele constituiu um meio de congregação nacional. Foi um dos elementos que forjou a comunidade imaginária, a qual coexistia simultaneamente no espaço social das salas de exibição, apreciando ali as mesmas mensagens. Diferia dos demais sistemas de comunhão midiatizada como a radiodifusão e a mídia impressa porque se localizava além da esfera privada. Funcionava como um passatempo que implicava na socialização e, portanto, envolvia escolhas deliberadas e expectativas coletivamente partilhadas ${ }^{5}$.

Já no final dos anos 1920, os grandes cineteatros de Berlim - os Ufa-Paläste, o Capitol, o Marmorhaus, o Gloria-Palast - haviam se transformado, na definição de Siegfried Kracauer, em imensos templos da distração, locais de culto ao entretenimento, o qual passou a definir a qualidade sedante da cultura aplicada às massas ${ }^{6}$. Quando em 1933 o nazismo cooptou o Estado alemão, encontrou no cinema um meio em crescente demanda e um dos espaços de entretenimento preferidos da sociedade. Filmes haviam evolvido para uma paixão nacional em

\footnotetext{
${ }^{4}$ Os números e a indexação aos gêneros provêm dos dados enumerados por Eric Rentschler, sendo também adotados por Mary Elizabeth O'Brien. O'BRIEN, Mary Elizabeth. Nazi Cinema as Enchantment: the Politics of Entertainment in the Third Reich. Rochester, Nova York: Camden House, 2004, 9 e RENTSCHLER, Eric. Op. cit., 7.

5 KALLIS, Aristotle A. Nazi Propaganda and the Second World War. Hampshire: Palmgrave Macmillan, 2005, 186.

${ }^{6}$ KRACAUER, Siegfried. Culto à distração in KRACAUER, Siegfried. O ornamento da massa. Tradução: Carlos Eduardo Machado e Marlene Holzhausen. São Paulo: Cosacnaify, 2009, 343-4 e KRACAUER, Siegfried. Shelter for the homeless in KRACAUER, Siegfried. The Salaried Masses: Duty and Distraction in Weimar Germany. Tradução: Quintin Hoare. Nova York: Verso, 1998, 94.
} 
crescimento exponencial 7 .

Longe de se ressentirem com o choque ideológico nazista, os setores hegemônicos da indústria cinematográfica empenharam-se em garantir junto ao novo governo vantagens que assegurassem seu futuro econômico ${ }^{8}$. O que não impediu que, em 1939, as maiores companhias terminassem estatizadas, com o propósito de simplificar o financiamento dos filmes, de enrijecer o controle dos conteúdos e de eliminar a competição de mercado, alinhando as empresas num sistema de produção cooperativa ${ }^{9}$. Goebbels logrou assim cooptar esse meio de comunicação, preservando-o como um feudo privado, poupando-o das disputas internas que atomizaram o potencial publicitário das demais plataformas midiáticas ${ }^{10}$. Estabeleceu uma Filmpolitik, uma política especialmente voltada ao cinema para conformar os sistemas de produção aos propósitos do regime. Instituiu um aparelho estatal de supervisão de cada setor da atividade cinematográfica encabeçada pela RFK (Reichsfilmkammer; Câmara de Filmes do Reich), subordinada ao RMVP (Reichsministerium für Volksaufklärung und

\footnotetext{
${ }^{7} \mathrm{Na}$ época weimariana, as produções de primeira linha eram prestigiadas por uma média de 18 milhões de espectadores e algumas realizações ultrapassaram massivamente essa cifra. Daí, entre 1920 e 1929, a afluência às salas de exibição saltou de 250 para 350 milhões de pessoas, seguindo como uma tendência sustentável até a época nazista, mesmo nos períodos mais duros da guerra. Também em cidades pequenas, o gosto pelos filmes foi cultivado em salas de dimensões modestas ou com unidades móveis de projeção. Assim, em 1937, a Alemanha atingiu a marca de 400 milhões de espectadores nativos. Na medida em que o Reich posteriormente incorporou novos territórios, essa audiência tornou-se mais massiva. Incluiu 623 milhões de espectadores após a anexação da Áustria e chegou a mais de um bilhão de pessoas em 1942, mantendo essa cifra entre 1943 e 1944. ELSAESSER, Thomas. Weimar Cinema and After: Germany's Historical Imaginary. Londres: Routledge, 2008 283, KALLIS, Aristotle A. Op. cit., 213, PETLEY, Julian. Capital and Culture: German Cinema 1933-45. Londres: British Film Institute (BFI), 1979, 59, 75, 87 e SCHOEPS, Karl-Heinz. Op. cit., 210.

8 PETLEY, Julian. Op. cit., 1-5.

${ }^{9}$ Entre 1936 e 1937, aproveitando-se da precária situação financeira das duas maiores companhias cinematográficas alemãs, a UFA e a Tobis, Goebbels capturou a maior parte das ações das empresas. O mesmo procedimento foi adotado posteriormente com as demais companhias da Alemanha - Bavaria e Terra - além da Wien-Film austríaca depois do Anschluß e a Prag-Film após a ocupação da Tchecoslováquia. De tal maneira que, no início de 1942, um gigantesco truste, a UFI (UFA-Film $\mathrm{GmbH}$ ) controlava secretamente toda indústria cinematográfica do bloco germânico. SCHOEPS, Karl-Heinz. Op. cit., 207 e WINKEL, Roel: Vande, WELCH, David. Europe's New Hollywood? The German Film Industry under Nazi Rule, 1933-45 in WINKEL, Roel Vande, WELCH, David (eds.). Cinema and the Swastika: the International Expansion of the Third Reich Cinema. Hampshire: Palgrave Macmillan, 2011, 18.

${ }^{10}$ KALLIS, Aristotle A. Op. cit., 213 e LONGERICH, Peter. Joseph Goebbels: uma biografia. Tradução: Luiz A. de Araújo. Rio de Janeiro: Objetiva, 2014, 319-30.
} 
Propaganda; Ministério do Reich para Esclarecimento Popular e Propaganda) ${ }^{11}$. Essa normatização, igualmente, obrou para remodelar a recepção dos filmes, de tal maneira que a audiência experimentasse não apenas a submersão no imaginário das obras, mas também a absorção no espaço público da sala de exibição ${ }^{12}$.

Os cinemas e os programas de exibição, indicaram Karsten Witte e Erica Carter, tornaram-se, portanto, uma mise en scène da identidade nacional mesmo quando o público procurava por obras de entretenimento ${ }^{13}$. Promoviam a fusão das culturas alta e baixa, intensificando a experiência espectatorial numa forma de totalização que rescendia ao ideal romântico da $\operatorname{arte}^{14}$. Guardavam a reminiscência daquela reforma cultural almejada por Richard Wagner em Bayreuth, na qual Adorno reconheceu um projeto de aplicação de uma arte total

\footnotetext{
${ }^{11}$ Uma série de medidas legislativas efetivou de maneira subterrânea esse desígnio, notadamente a Lei de Cinema do Reich de 1934 que substitui o código legislativo de 1920, ampliando as prerrogativas da censura política. A partir do ponto de vista de que somente as autoridades do Partido detinham as credenciais para emitir julgamentos artísticos e fixar o valor político de cada obra, normas adicionais suspenderam a crítica cinematográfica em 1936. Em seu lugar, instituíram revisões descritivas, as quais não disputavam com o regime a fixação da mensagem das obras. In toto, essa legislação impôs a supervisão dos projetos, revisão dos roteiros, limitação de importação de filmes estrangeiros e favorecimento comercial de produções de propaganda afirmativa premiadas com uma honraria concedida pelo Estado, o Prädikat ("Predicado": condecoração orientada para escalonar a relevância política de cada filme que, dependendo de seu ranking, dispunha das facilidades oferecidas pelo Estado na distribuição e de acesso favorecido às salas de exibição). KREIMEIER, Klaus. The Ufa Story: a History of Germany Greatest Film Corporation, 1918-1945. Tradução: Robert Kimbler, Rita Kimbler. Berkeley, Los Angeles: University of California Press, 1999, 290, SCHOEPS, Karl-Heinz. Op. cit., 207, PETLEY, Julian. Op. cit. 96-8 e WELCH, David. Propaganda and the German Cinema 1933-1945. Londres: I..B. Taurus, 2001, 13-8.

12 Os cinemas passaram a ser tratados como o local de uma apreciação contemplativa na qual o público deveria se regozijar com o filme e também com sua inclusão na coletividade representada pela plateia. Por isso, o regime voltou-se à transformação da audiência desorganizada do período de Weimar num público disciplinado, organizado e hierarquizado, promovendo uma reconfiguração geral do espaço espectatorial. Segmentou a audiência em diferentes categorias. Fixou assentos privilegiados para os militares, os membros da SS, da SA e os dignitários do regime. A programação das sessões foi rigidamente orquestrada de acordo com o tamanho e o status da casa de exibição. As sessões duplas terminaram abolidas com a finalidade de evitar o excesso de estímulos e favorecer programas tematicamente coerentes, os quais deveriam incluir anúncios publicitários, reportagens jornalísticas, um Kulturfilm (documentário educacional) e, por fim, um longa-metragem. CARTER, Erica. Dietrich's Ghosts: the Sublime and the Beautiful in the Third Reich Film. Londres: British Film Institute (BFI), 2011, 38, 110.

${ }^{13}$ CARTER, Erica. Op. cit., 87, 94-9 e WITTE, Karsten. How Nazi Cinema Mobilizes the Classics: Schweikart's Das Fräulein von Barnhelm (1940) in RENTSCHLER, Eric (ed.). German Film \& Literature: Adaptations and Transformations. Nova York, Londres e Methuen, 1986, 104.

${ }^{14}$ KOEPNICK, Lutz. The Dark Mirror: German Cinema between Hitler and Hollywood. Berkeley, Los Angeles: University of California Press, 2002, 92, 94.
} 
consagrada à regeneração do povo alemão pelos vínculos da germanidade, a qual transcendia as fronteiras de classe ${ }^{15}$. Porém, ao contrário do festival, que de modo algum privilegiou a espetacularização para um público inapto a apreciar aquela grande cena nacional, a cultura nazificada jamais dispensou os impulsos populistas dos quais o regime dependia para subsistir. Ao contrário da arte total wagneriana, a arte totalizada nazista pretendia apelar a todos os segmentos sociais. Era, por isso, devotada aos fundamentos da cultura de massa industrializada pela tecnologia e investida num programa de reconstrução nacional da sociedade pela distração e pelo consumo ${ }^{16}$.

A nacionalização da produção e a domesticação da audiência não almejavam apenas a doutrinação do público, mas também a reinserção da Alemanha no mercado internacional de cinema e atendia à pretensão do RMVP de liderar uma renovação do meio cinematográfico europeu a partir de Berlim. O que implicou a instituição cinematográfica no largo projeto de dominação ideológica sobre os países satélites, com vista a acorrentá-los às tradições alemãs e a estabelecer a hegemonia nazista à frente do bloco fascista europeu ${ }^{17}$. Consequentemente, em todos os setores da criação cultural, os artistas foram investidos com o dever de engendrar uma nova arte que reverberasse a verdade do nacional-socialismo. Tornaram-se, numa célebre expressão da época, os "soldados da arte", à frente de uma missão reformadora. A precisa natureza da reforma que deveriam perseguir, contudo, os ideólogos mostraram-se incapazes de estabelecer ${ }^{18}$. A produção cultural no período nazista progrediu, por isso, num permanente arranjo entre artistas no encalço de seus interesses prticulares e as organizações políticas que promoviam erraticamente quem a elas aderisse com mais entusiasmo. A criação artística no Terceiro Reich tornou-se, por conseguinte, um processo de constante negociação. Pelo que a visão estética dos

\footnotetext{
${ }^{15} \mathrm{ADORNO}$, Theodor W. Introdução à sociologia da música. Tradução: Fernando R. de Moraes Barros. São Paulo: Editora Unesp, 2011, 239-40.

${ }^{16}$ KOEPNICK, Lutz. Op. cit., 94.

17 BENJAMIN, George Martin. European Cinema for Europe" The International Film Chamber, 193542 in WINKEL, Roel Vande: WELCH, David (eds.). Op. cit., 25-36.

18 CARTER, Erica. Op. cit., 34, 63, 66, 77 e CLINEFELTER, Joan. Artists for the Third Reich: Culture and Race from Weimar to Nazi Germany. Oxford, Nova York: Berg, 2005, 106, 100, 119, 128, 121.
} 
próprios artistas, na maioria dos casos, provia aos doutrinadores a chave de elucidação para o epíteto arte nazista, o qual, per se, sempre padeceu da falta de uma fixação conceitual ${ }^{19}$.

A arte cinematográfica na Alemanha nazificada, se não proveu a exceção a essa norma, decerto foi sistematizada por uma única mente que vislumbrou nela a miragem de um experimento próprio à nova ordem. Os filmes, sob o comando de Goebbels, demonstraram tal flexibilidade que os tornara apropriados a servir para diferentes finalidades: diversão, esclarecimento político, propaganda ideológica, afirmação da hegemonia cultural alemã, integração social. Suspendendo a dualidade entre arte e política e combinados com outras plataformas midiáticas, participaram de uma divisão de trabalho ideológico no qual sua função flutuava entre o desejo dos espectadores e a afirmação da doutrina $^{20}$. Pois Goebbels e sua entourage de ideólogos concordavam que a propaganda se tornava mais eficiente se embalada com o apelo das emoções ${ }^{21}$. Os longas-metragens promoviam melhor a doutrina quando investiam em valores culturais que coincidiam com aqueles da audiência, provendo uma via de escape para os desejos subversivos dos espectadores. Os filmes de entretenimento pretendiam, então, influenciar politicamente suas plateias pelo envolvimento emocional, pela identificação com os personagens e com as estrelas e pela utilização dos gêneros preferidos pela audiência ${ }^{22}$.

O público alvo da regra totalitária, observou Hannah Arendt, não era o

\footnotetext{
${ }^{19}$ CLINEFELTER, Joan. Op. cit.., 99.

20 Inserido em meio a um caleidoscópio de plataformas midiáticas, o cinema participava ativamente daquilo que Goebbels denominou como "princípio de orquestra", pelo que uma mesma mensagem doutrinária podia ser modulada e distribuída harmonicamente em diferentes meios de comunicação: programas radiofônicos, meios impressos, documentários, cinejornais, discursos públicos. Assim, observou Aristotle Kallis e também Erica Carter, os filmes serviam sobretudo como um fator de equilíbrio, promovendo entretenimento, informação e esclarecimento em doses seriadas. CARTER, Erica. Op. cit., 5 e KALLIS, Aristotle A. Op. cit., 208. ${ }^{21}$ A desastrosa acolhida de filmes de propaganda ostensiva como Hitlerjunge Quex (Mocidade heroica, Hans Steinhof, 1933) e Hans Westmar: einer von Vieler ("Hans Westmar, um entre muitos", Franz Wenzler, 1933) firmou a convicção defendida por Goebbels de que, ao invés da saturação ideológica e da doutrinação direta, era pela fixação da hegemonia cultural que o cinema podia cumprir um papel ideológico relevante. Doravante, o Ministro impôs à produção cinematográfica o desígnio de capturar a imaginação da audiência pela alusão aos acontecimentos, situando os fatos políticos num continnuum com a obra ficcional sob o registro do entretenimento. KALLIS, Aristotle A. Op. cit., 195-6, 187 e PETLEY, Julian. Op. cit., 101.
}

22 O'BRIEN, Mary Elizabeth. Op. cit., 1. 
nazista convicto nem os acólitos instruídos na doutrina. O nazismo almejava atrair os demais simpatizantes, os cidadãos ordinários que, de modo algum, poderiam ser qualificados como fascistas fanáticos. Para eles, a propaganda, então, tomava formas mais amenas e palatáveis. A cooptação dessa camada de observadores passivos, que aquiesciam às mensagens do regime sem fazer delas uma crença ideológica, almejava tanto prover legitimidade à nova ordem, fazendo-a parecer representativa a setores mais amplos da sociedade, quanto desencorajar os grupos de resistência à totalização ${ }^{23}$. Por conseguinte, no Terceiro Reich o cinema se comutou mais num dispositivo de distração do que de doutrinação. Daí que a crescente deterioração do regime nos anos 1940 fosse acompanhada pelo marcante declínio dos filmes de cunho doutrinário. A proporção entre Unterhaltungsfilme e obras políticas pendeu a favor da primeira categoria, uma tendência que se tornaria mais acentuada a partir de 1942, quando ela constituiu $80 \%$ da produção, até os anos finais da guerra ${ }^{24}$.

Após a capitulação alemã, esses filmes foram indexados à lista de produtos proscritos da cultura de massa e, doravante, permaneceram na categoria das mercadorias malditas que arrastavam consigo a nêmese e os miasmas do Terceiro Reich $^{25}$. O que os implicou numa historiografia de negociação, pela qual reiteradamente foram tratados como artefatos a serviço do engodo. Em 1947, Siegfried Kracauer emitiu o primeiro juízo de valor referente a essas obras, o qual produziu efeitos determinantes nas análises subsequentes. "Certamente, todos os filmes nazistas foram em maior ou menor medida filmes de propaganda", asseverou, "mesmo os filmes de mero entretenimento que parecem distantes da política” 26 .

Seguindo Kracauer, Julian Petley argumentou que, no âmbito nazista, não existiram filmes não ideológicos. A partir das formações sociais onde as obras eram realizadas e apreciadas, Petley admitiu a cisão entre filmes de propaganda e de

\footnotetext{
${ }^{23}$ ARENDT, Hannah. The Origins of Totalitarism. Nova York: Harcourt, 1997, 367.

24 SCHOEPS, Karl-Heinz. Op. cit., 209-10.

${ }^{25}$ ELSAESSER, Thomas. Op. cit., 283.

${ }^{26}$ KRACAUER, Siegfried. From Caligari to Hitler: a Psychological History of the German Film. Princenton: Princenton University Press, 2004, 275.
} 
entretenimento, mas não discerniu um cinema político de outro não-político ${ }^{27}$. Mesmo que voltados à diversão e destituídos de mensagens partidárias, considerou Aristotle Kallis, cumpriam, pois, propósitos ideológicos. Ofereciam uma rota de fuga provisória quando a realidade contradizia os discursos oficiais do regime, pelo que o entretenimento e a doutrina permaneciam balanceados, operando complementarmente ${ }^{28}$.

As mensagens nazistas, observou Erica Carter, emanavam de uma cadeia hierárquica sob mecanismos de coerção no polo da produção e de permanente negociação com a audiência em busca de modelos estéticos simultaneamente conformes à doutrina e ao gosto popular ${ }^{29}$. Na mesma linha, Mary Elizabeth O’Brien assinalou que a influência ideológica do governo encetada nos filmes dependia então de sua eficiência em localizar e satisfazer as necessidades emocionais e psicológicas do público. Por esse meio, os filmes serviam como um verniz para revestirem tópicos polêmicos numa embalagem aprazível a qual os faziam soarem aceitáveis. Participavam de um esforço de propaganda invisível pela qual a agência fascista permeava o enredo e as motivações dos personagens no background da ação ${ }^{30}$.

O cinema da Alemanha nazista, sugeriu, daí, Richard Taylor, voltou-se ao desejo para, mediante ele, aceder à doutrina. Buscou cultivar respostas passivas da plateia, sujeitando suas mensagens a um regime de encantamento pela distração (ou, na expressão lapidar de Mary Elisabeth O’Brien, um encantamento da realidade). Os filmes, sob o ponto de vista de Taylor, tenderam a um escapismo radical, descolando-se da conjuntura imediata para reajustar a realidade numa moldura idealizada pela fantasia. Esse cinema constituiu, ao seu ver, um experimento inovador em propaganda política porque se dispunha a abandonar

\footnotetext{
27 A solicitação ideológica, considerou Petley, não se determinava apenas pelos mecanismos de formalização da mensagem nem se restringia ao texto. Em casos paradigmáticos como Jud SüB ("Judeu Suss", Veit Harlan, 1940) e Ohm Krüger ("Tio Krüger", Hans Steinhoff, 1941) a mensagem doutrinária se fazia completa pelo modo como as instituições sociais operavam cooperativamente. Filmes tornaram-se, então, ferramentas de propaganda graças à sua inscrição num contexto para encetar uma resposta pré-determinada da audiência. PETLEY, Julian. Op. cit., 7-8, 95-6, 102.

${ }^{28}$ KALLIS, Aristotle A. Op. cit., 209.

${ }^{29}$ CARTER, Erica. Op. cit., 8-9.

${ }^{30} \mathrm{O}^{\prime}$ BRIEN, Mary Elizabeth. Op. cit., 8, 10.
} 
as correntes ideológicas e suas bases doutrinárias para empreender uma mutação programada das ideias e dos valores sociais numa política de espetáculo e diversão ${ }^{31}$.

Abandonando o campo minado que alinhou o projeto de totalização da sociedade às práticas da cultura de massa, análises recentes passaram a cartografar outros territórios de inscrição histórica desses filmes. Esses estudos rejeitaram as interpretações sintéticas que inteiravam a doutrina totalitária, o imaginário fascista, a propaganda política e o texto semiótico das obras num único campo discursivo. Objetaram, primeiramente, que os filmes mais populares lançados na época do nazismo apelavam para estruturas narrativas convencionais com as quais o público se sentia à vontade, voltando-se a elas e as apreciando como meios de diversão e não de educação política ${ }^{32}$. As audiências da Alemanha nazista tornaram populares as produções que lhes correspondiam sem em absoluto sujeitarem seus desejos em fantasias que lhes fossem alheias ${ }^{33}$. Daí que o cinema oriundo do Terceiro Reich, advertiu Sabine Hake, vinha sendo erroneamente tratado como o derradeiro outro, a alteridade aberrante da arte cinematográfica. Excluídas de retrospectivas acadêmicas e sem o benefício de análises fílmicas, as obras terminaram acantonadas aos ensaios sobre propaganda política e crítica ideológica, o que prontamente resultou na sua redução ao domínio da tese da manipulação das massas e da passividade espectatorial ${ }^{34}$.

${ }^{31}$ O'BRIEN, Mary Elizabeth. Op. cit., 1-2 e TAYLOR, Richard. Film Propaganda: Soviet Russia and Nazi Germany. Londres, Nova York: I. B. Taurus, 2009, 209-10.

32 SCHOEPS, Karl-Heinz. Op. cit., 209.

33 A despeito de todos os sistemas de controle e censura, observou Thomas Elsaesser, remanesceram áreas de fissuras pelas quais a inflexão doutrinária encontrava resistências, por vezes insuperáveis, no momento da recepção. Numa variedade de casos, critérios de mercado e as expectativas de exportação prevaleciam, pelo que apenas se preservavam nos filmes elementos ideológicos que fossem atraentes aos espectadores, livres de assuntos políticos. Em outras situações, os filmes eludiam os censores que somente logravam reconhecer os conteúdos indesejáveis quando as obras já estavam consagradas junto ao público.

ELSAESSER, Thomas. Op. cit., 385, 388, 411.

${ }^{34}$ HAKE, Sabine. Popular Cinema of the Third Reich. Austin: University of Texas Press, 2001, VIII, 1. 
Fundamentalmente, Hake recusou a tendência prevalente de extirpar essas obras de sua ambiência global - a ideologia burguesa nas suas variadas expressões nativas - para as calcar no círculo fechado de uma única prática política. Longe de se confinarem à propaganda ou à coparticipação num regime de entretimento escapista, os filmes da época nazista, enfatizou Hake, não foram uma exceção divergente ao cinema popular do século XX. Neles convergiam aspectos da tradição cinematográfica às diretrizes políticas do regime em processos de negociação raramente destituídos de posições conflitantes. O que impunha a necessidade de outras aproximações teóricas para mensuração de suas múltiplas funções como instituição cultural, experiência comunal, plataforma de debate público e máquina de produção social do desejo ${ }^{35}$.

Porque desempenharam papéis contraditórios, os filmes do período nazista, ponderou Aristotle Kallis, remanesceram como um objeto mal situado entre a arte de massa e a propaganda política. À sua época, não parecia conflitante aos seus espectadores que as produções lhes oferecessem as formas, estrelas e estilos oriundos da época do regime liberal weimariano. Pois era assim que também atendiam à agenda totalitária. Trata-se, portanto, de um cinema que desafia a fixação nas categorias estanques de doutrinação ou de entretenimento ${ }^{36}$. O que implica reconhecer nele uma latitude de sentidos ampla o bastante para admitir leituras opostas e interpretações alternativas sem com isso esterilizar seu papel ideológico tanto como instrumento doutrinário, quanto como mercadoria da indústria cultural ${ }^{37}$. De tal maneira que, numa variedade de investigações, surgiram os primeiros traços da problemática adjacência de um cinema dito nazista com seu oposto polar, o outro cinema, nunca de fato diagnosticado como democrático ou liberal.

Wagner Pereira Pinheiro, por exemplo, estabeleceu importantes conexões funcionais entre os cinemas pautados pelo fascismo alemão e pelo liberalismo norte-americano. Atestou que ambos coincidiam numa organização dos meios produtivos baseada na industrialização planejada de filmes em grandes estúdios,

\footnotetext{
${ }^{35}$ HAKE, Sabine. Op. cit., IX, 3-4.

36 KALLIS, Aristotle A. Op. cit., 185.

37 ELSAESSER, Thomas. Op. cit., 385
} 
na promoção desses em torno de um sistema de estrelas e na prática de censura (orientada à preservação de laços e valores sociais, morais e religiosos) para respaldarem as políticas adotadas pelos seus respectivos governos e para modularem a imagem de um "novo homem" 38. Karl-Heinz Schoeps, por seu lado, mapeou nos filmes da época fascista sistemas de contiguidade cultural resistentes às rupturas políticas que separaram a democracia weimariana do Terceiro Reich e esse das Alemanhas Ocidental e Oriental. Concluiu que o fator determinante do papel social dessas obras era o gradiente oscilante de propaganda política nelas fixada. A ausência de publicidade nazista "ostensiva" na maior parte desses filmes permitiu-lhes sustentar sua popularidade mesmo depois que o contexto de sua produção desapareceu ${ }^{39}$.

Tais reapropriações expandiram as linhas de análise e abriram frentes de debates para a articulação de problemas originais. Permitiram indagações acerca do apelo que essas obras ainda retêm na contemporaneidade. O espírito das aventuras do irresistível Barão de Münchhausen (Josef von Baky, 1943) e a graça de Heinz Rühmann, o perseverante bom burguês alemão, atravessaram o gap de muitas décadas e sobreviveram à conturbada história de cisão e sutura da Alemanha. Esse fenômeno permaneceria incompreensível sob o ponto de vista de uma historiografia que alinhava inextricavelmente tal cinema com seu contexto político ${ }^{40}$.

Sob o ponto de vista de Thomas Elsaesser, filmes constituem uma memória coletiva. Eles presentificam a realidade imediata por meio do aparato de reprodução, mas também invocam o prazer da submersão nas imagens e essas são resistentes à fixação unívoca. De modo que servem retrospectivamente para escrever uma outra história que se contrapõe à história oficial. Recuperam parcelas mais complexas da memória social e do seu Zeitgeist, o espírito do seu tempo. Disso, Elsaesser descreveu uma imagem clarividente daquelas obras até então, invisível ao olhar historiográfico que assistia às cenas por um espelho

\footnotetext{
38 PEREIRA, Wagner Pinheiro. O poder das imagens: cinema e politica nos governos de Adolf Hitler e de Franklin D. Roosevelt (1933-1945). São Paulo: Alameda, 2012, 647-8, 651.

39 SCHOEPS, Karl-Heinz. Op. cit., 205.

${ }^{40}$ ELSAESSER, Thomas. Op. cit., 384.
} 
retrovisor, mirando o passado numa moldura mental pré-fabricada. Em comparação com as realizações da época weimariana, os filmes do período fascista promoviam textos e representações muito mais ousados em termos eróticos. Eram também mais carregados de energia, de pathos emocional, mais estridentes e mais acelerados na montagem. Do que Elsaesser inferiu que, mesmo na época nazista, o cinema persistiu cumprindo com crescente proficiência uma agenda alheia à mera doutrinação, voltando-se a administração social do desejo nos mesmos termos da ideologia liberal. Pois, no seu passo veloz, os filmes, concluiu Elsaesser, sustentavam uma cultura de consumo e entretenimento, reconstituindo mundos imaginários onde esses hábitos sobrevinham investidos de significação social. Continuaram, por isso, extremamente populares, exibidos em casas com lotação esgotada até 1945, nos estertores do regime, ainda atraindo uma plateia que, mesmo castigada pela guerra, procurava espontaneamente neles modos de vida baseados numa experiência comunal. E, depois disso, retiveram seu apelo porque midiatizaram universos tipificados pela moda, pelo turismo, pelos estilos de vida e por tudo que podia inscrever uma comunidade numa história partilhada e numa identidade cultural ocidental ${ }^{41}$. De maneira que aquele cinema caracteristicamente narrativo e clássico, oriundo da indústria cultural e voltado ao consumo popular, não mais se subsumia a uma agência a serviço de uma doutrina radical, mas se transformava num modelo de difusão ideológica prevalente em toda sociedade estatizada, democrática ou autoritária. O que, por fim, conduziu a discussão ao problema de fundo de qualquer cinema fabricado para entretenimento das massas.

Pierre Sorlin definiu a imagem cinematográfica como um território de lutas. Nela, conteúdos disputam espaço para estabelecerem uma relação única entre o que se permite enxergar e o que foi votado a desaparecer ${ }^{42}$. No que acompanhou Marc Ferro para reconhecer a existência de conteúdos paradoxais, que ora se submetem, ora eludem aos controles, às afirmações das ideologias e aos esquemas doutrinários. Ferro e Sorlin entreviram na imagem fílmica não apenas

\footnotetext{
${ }^{41}$ ELSAESSER, Thomas. Op. cit., 384, 408-9, 414.

42 SORLIN, Pierre. Sociologie du cinema: Ouverture pour l'histoire de demain. Paris: $6^{\circ}$ Aubier Montaigne, 1977, 73-4, 242.
} 
aquilo que ilustra discursos, mas também o que se interpõe a eles, acusando sua artificialidade: uma imagem na qual se confirmam e se desmentem os textos que a amparam porque ela arrasta consigo um saber autônomo. Não comporta somente a realidade que emula, mas também aquela que desfigura. Nessa dupla instância, o latente repousa no aparente, o não-visível atravessa o visível. Seguindo a ideologia, o filme então a ultrapassa ${ }^{43}$.

Esse movimento elástico, atestado por Ferro e Sorlin, pelo qual a imagem e a ideologia conformam uma à outra, orientou a presente investigação do cinema da época nazista. Pelo estudo de quatro filmes dos anos 1940, a pesquisa mapeou a relação entre a fantasia tramada nas produções, os desejos sociais de seus espectadores e as injunções da propaganda doutrinária. Tomando a ferramenta da análise psicanalítica nas linhas freudiana e lacaniana como instrumento da interpretação, a pesquisa presumiu uma conexão produtiva entre $\operatorname{desej} o^{44}$,

\footnotetext{
${ }^{43}$ Num filme, o visível flutua dentro de um quadro previamente emoldurado pelas ideologias. A tela não revela o mundo enquanto tal, mas aquilo que a partir dele se presumiu pelas ideias, o que foi passível de ser contido e duplicado em um recorte. Perscruta o que as ideologias determinaram como relevante. Assim, nas suas imagens, a obra cinematográfica reconstrói afirmativamente a ideologia. Com suas visões estilizadas, contudo, forçam o acento seletivo em alguns aspectos, de tal maneira que também perfazem o caminho oposto: reconstroem retroativamente na ideologia as imagens por ela negligenciadas. FERRO, Marc. Le film: une contreanalyse de la société in FERRO, Marc. Cinéma et histoire. Paris: Gallimard, 2009, 39-40, 42, LEBEL, Jean-Patrick. Cinema e ideologia. Tradução: Jorge Nascimento. Lisboa: Editorial Estampa, 1975, 12 e SORLIN, Pierre. Op. cit., 33, 68-9.

${ }^{44} \mathrm{O}$ conceito de desejo aplicado a esta pesquisa corresponde àquele da teoria lacaniana. Refere-se, portanto, à inclinação objetal que somente encontra alguma possibilidade de satisfação pelo gozo, avançando para além das margens do objeto. Porque se afasta da realização num objeto material, o desejo resiste, então, em estado de distensão. Subiste inconscientemente, de acordo com Lacan, como o desejo do Outro numa dupla determinação: o outro, grafado com inicial minúscula ou pela letra $a$ no lugar da dualidade do eu (o outro especular, imaginariamente constituído) e o Outro, com inicial maiúscula ou sinalizado na letra $A$, entendido como o inconsciente enquanto lugar da fala (o grande Outro da linguagem, a estrutura que preexiste ao sujeito e contém todos os as, o território do símbolo, o loco de desdobramento onde o desejo de um homem coincide com o desejo dos demais). ALAIN-MILLER, Jacques, Percurso de Lacan: uma introdução. Tradução: Ari Roitman. Rio de Janeiro: Zahar, 1997, 22, LACAN, Jacques. Livre XI Les quatre concepts fondamentaux de la psychanalyse. Paris: Éditions du Seuil, 1990, 146, LACAN, Jacques. O seminário livro 5: as formações do inconsciente. Tradução: Vera Ribeiro. Rio de Janeiro. Zahar, 1999, 282, LACAN, Jacques. O seminário Livro 6: o desejo e sua interpretação. Tradução: Claudia Berliner. Rio de Janeiro: Zahar, 2016, 309, LACAN, Jacques. O seminário, livro 7: a ética na psicanálise, 1959-1960. Tradução: Antônio Quintet. Rio de Janeiro: Zahar, 2008, 221, 242, LACAN, Jacques. O seminário Livro 8: a transferência. Tradução: Dulce Duque Estrada. Rio de Janeiro: Zahar, 2016, 225, LACAN, Jacques. O seminário, livro 16: de um Outro ao outro. Tradução: Vera Ribeiro. Rio de Janeiro: Zahar, 2008, 111 e ROUDINESCO, Elisabeth: PLON, Michel. Dicionário de psicanálise. Tradução: Vera Ribeiro, Lucy Guimarães. Rio de Janeiro: Zahar, 1998, 558-9.
} 
fantasia $^{45}$, ideologia e doutrina ${ }^{46}$ num arranjo instrumental útil às análises das obras a partir de duas premissas: 1) o nazismo presumido como uma doutrina de

\begin{abstract}
45 A fantasia, de acordo com a teoria psicanalítica, regula a fixação do desejo, determinando sua situação. Assim, ela satisfaz as exigências de dois domínios psíquicos. Do ponto de vista freudiano, designa a vida imaginária do sujeito, a maneira como ele representa para si mesmo sua própria história perfazendo uma parcela da atividade psíquica exclusivamente voltada ao princípio do prazer (pelo que, igualmente, responde pelas sensações de contentamento derivadas da experiência espectatorial). E, pela perspectiva lacaniana, refere-se à existência simbólica, à relação entre homem e a linguagem. Mediante os enredos de suas fantasias, o sujeito procura não apenas a descarga psíquica pelo prazer, mas também fixar a si mesmo num objeto especial, inexistente na realidade, o qual Lacan nomeou petit objet $a$. Esse pequeno objeto $a$ funciona como um aparato simbólico para captura do gozo. Seu modelo originário é o vestígio do falo imaginariamente castrado e, portanto, define-se nos termos da falta. Representa aquilo que o sujeito reconhece como desejado porque, sem ele, permanece destituído de uma parte de si. E, porque não há meios possíveis de enunciar essa castração, o objeto $a$ vem substituir a hiância, colocando-se em seu lugar como o resíduo de uma presença - deseja-se, então, não o objeto material, mas uma imagem idealizada nele presumida. ALAIN-MILLER, Jacques. Op. cit., 116, FREUD, Sigmund. Escritores criativos e devaneio, in FREUD, Sigmund. Obras psicológicas completas de Sigmund Freud Volume IX. Tradução: Maria Aparecida Moraes Rego. Rio de Janeiro: Imago, 1996, 135-9, FREUD, Sigmund. Personagens psicopáticos no palco, in FREUD, Sigmund. Obras psicológicas completas de Sigmund Freud Volume VIII. Tradução: José Octávio de Aguiar Abreu, Christiano Monteiro Oiticica. Rio de Janeiro: Imago, 1996, 297-300, LACAN, Jacques. O seminário Livro 6: o desejo e sua interpretação. Tradução: Claudia Berliner. Rio de Janeiro: Zahar, 2016, 28, 242, 308, 373, LACAN, Jacques. O seminário, livro 16: de um Outro ao outro. Tradução: Vera Ribeiro. Rio de Janeiro: Zahar, 2008, 240-1, 310, 335 e ROUDINESCO, Elisabeth: PLON, Michel. Op. cit., 2235.
\end{abstract}

${ }^{46}$ Para este estudo a noção de ideologia opera conforme às assunções de Althusser. Uma ideologia, nessa linha teórica, descreve os amplos sistemas de ideias para suporte à constituição da subjetividade. Uma ideologia, desse ponto de vista, não representa nem uma "falsa consciência", nem o resultado unilateral dos trabalhos doutrinários de uma classe social e de suas instituições (o Estado no âmbito público e, no domínio privado, as igrejas, os partidos, os sindicatos, os empreendimentos culturais, as escolas e a família). Trata-se, ao contrário, de um sistema de construção contínua de subjetividades mediante o qual indivíduos estabelecem coletivamente os parâmetros de decodificação imaginária da sua própria realidade. Por outro lado, nesta pesquisa, a noção de doutrina equivale ao conceito de ideologia transitória defendido por Gramsci. Uma ideologia transitória categoriza fênomenos distintos das ideologias orgânicas que atuam na organização das massas e na fixação da consciência dos sujeitos. Constituem movimentos de curta duração que não refundam estruturas historicamente determinadas e, por isso, terminam solapados pelas contradições que lhes são inerentes. Este estudo, por conseguinte, adota a diretriz de Gianfranco Pasquino, para quem o nacional-socialismo não produziu uma ideologia propriamente dita, persistente e unívoca, sólida o bastante para moldar a sociedade e o espaço político, mas sim uma doutrina de caráter transitório que colhia dos sistemas ideológicos pré-existentes aquilo que the convinha, misturando arbitrariamente passado e futuro, revolução e reação, cultura e barbárie. No mais, para os fins perseguidos pela pesquisa, não foram fixadas as distinções entre as noções de fascismo, nazismo e totalitarismo. A elas se adotaram as mesmas diretrizes apontas por Laclau, de modo que, nesse estudo, respeitadas as peculiaridades de cada conceito, todos eles funcionam como um sistema de termos relativamente equivalentes. ALTHUSSER, Louis. Ideologia e aparelhos ideológicos de Estado, in ŽIŽEK, Slavoj (org.) Um mapa da ideologia. Tradução: Vera Ribeiro. Rio de Janeiro: Contraponto, 1996, 115-7, 126-39, GRAMSCI, Antonio. O leitor de Gramsci: escritos escolhidos 1916-1935. Tradução: Carlos Nelson Coutinho (org.) Rio de Janeiro: Civilização Brasileira, 2011, 147-8, 189, LACLAU, Ernesto. Politics and Ideology in Marxist Theory: Capitalism, Fascism, Populism. Londres: NBL, 1977, 81-6, 89-103 e PASQUINO, Gianfranco. Curso de ciência política. Tradução: Ana Sassetti da Mota. Cascais: Principia, 2002, 287. 
pactuação fundada nas bases mais amplas da ideologia burguesa-patriarcal e 2) o cinema entrevisto enquanto meio de intermediação que translada, na forma flutuante das fantasias, as suturas entre o desejo, a ideologia e a doutrina. A partir do que abordou, a cada capítulo, os problemas e óbices à enunciação da doutrina pelo agenciamento da fantasia fílmica em uma dada realização cinematográfica.

Numa produção voltada à promoção do genocídio judaico, Jud Süß ("Judeu Süss", Veit Harlan, 1940), a investigação se voltou à emblemática fantasia do sacrifício de uma virgem para fundação da comunidade social masculina. Do que perscrutou as expressões subterrâneas do desejo fusional pelo qual a fragmentada nação alemã imaginava sua síntese ao redor de uma dupla violência dirigida simultaneamente ao outro racial e à mulher, formulada a partir de um drama histórico, mas modulada como história de horror.

Num filme considerado como o mais bem-sucedido woman's picture do período nazista, Die große Liebe (“O grande amor”, Rolf Hansen, 1942), a pesquisa procurou os dispositivos de representação pelos quais o feminino encetou, numa conturbada conjuntura sociopolítica, expressões originais, autônomas e transgressivas, contradizendo o ideal doutrinário da "nova mulher" fascista, ao mesmo tempo em que subsidiava uma vacilante renovação imaginária da masculinidade em crise no ocaso da Blitzkrieg.

A análise de Münchhausen (Josef von Baky, 1943), o filme mais celebrado do Terceiro Reich, perscrutou, na desenfreada fantasia ancorada no maravilhoso, a censura à lógica racional pelo que a obra instaurava um universo regido pelo desviante. Nesse mundo transtornado, a pesquisa investigou as articulações que se desviavam da representação idealizada que o regime fazia de si para colocar, em seu lugar um imaginário extraordinário, o qual acessava diretamente ao princípio do prazer e assim escancarava a polimórfica face do "novo homem" conjurado pela nova ordem.

Por fim, a análise se aproximou daquele que tem sido tratado como o caso mais emblemático de fracasso da propaganda política nazista, o monumental disaster movie, Titanic (Herbert Selpin, 1943). Ao contrário dos estudos precedentes, esta investigação localizou na obra evidências dos mecanismos de 
pactuação pelo que a doutrina transmutava, nos termos do desejo, os mais sombrios cenários. A partir do que, ocupou-se em localizar as tramas invisíveis que urdem o imaginário e o real em torno de expectativas socialmente partilhadas e orientadas para além do princípio do prazer, quando o desejo flerta com a pulsão de morte.

Essa amostra de realizações da fase final do Terceiro Reich se restringiu a uma pequena seleção de produções comissionadas pelo RMVP no momento culminante de crise do projeto de Estado total alemão entre 1939 e 1945 . Do ponto de vista das agências doutrinárias, as quatro obras almejavam promover ações políticas específicas numa conjuntura de contradições e mistificação ideológicas cada vez mais agudas devido ao crescente custo social da guerra e ao consequente decréscimo da popularidade do regime nazista junto à sociedade. Perseguindo seus propósitos panfletários, filme após filme, o tom das produções cinematográficas abandonou as sublimes exortações ao regime e ao volátil cabedal de crenças fascistas para se voltar, às vésperas da derrocada do Reich, a cenários imaginários, emoldurados dentro de uma crescente histeria patriótica. O background dessas realizações desfaz, portanto, qualquer margem de dúvida quanto aos seus propósitos políticos imediatos. Tratando-se de filmes abertamente motivados pelo imperativo da reafirmação da doutrina nazista em declínio, neles, os conflitos entre a intencionalidade de suas representações e a necessidade de apelar aos desejos sociais dos espectadores em fantasias atraentes aparecem, portanto, de modo mais explícito. Porque essas obras pretendiam atender simultaneamente ao desejo e à doutrina na forma flutuante da fantasia cinematográfica, seus enunciados oferecem evidências incontestáveis da conjuntura de franca atrição entre um domínio e o outro. Pelo que suas mensagens ideológicas provêm uma dupla face conflitante cuja lisibilidade este estudo pretende contemplar na chave da leitura psicossocial. 


\section{Capítulo 1 \\ Judeu Süss \\ (Jud Süß, 1940)}

Numa carta de julho de 1948 endereçada ao rabino Dr. Joachim Prinz, às vésperas de ser julgado em Hamburgo, Veit Harlan defendeu que não era ele, mas sua obra Jud Süß que ia a julgamento "A acusação declara: um filme inflamado, que deforma os judeus e, portanto, estimulava o pogrom", escreveu. “A resposta da defesa será: não um filme inflamado, mas a apresentação da questão judaica em termos artísticos, não um retrato distorcido, mas uma expressão de assuntos importantes, de preocupações humanas". Ao que o rabino lhe respondeu que "mesmo a arte pervertida pode ser perfeita"1.

Por uma "arte pervertida", o rabino enumerava dois juízos que fizeram de Jud Süß um experimento social devastador. 1) O poder sugestivo de uma forma exemplarmente construída para comover sua plateia, para a impressionar e a convidar a uma linha específica de ação: “Já conversei com pessoas que viram com seus próprios olhos, em Cracóvia em 1945, por exemplo, quais efeitos seu filme produzia e aquelas que, mais tarde, tiveram, elas próprias, de sofrer por ele”. E 2) a janela de oportunidade que tornava sua mensagem tão poderosa: “um momento em que milhares de megafones na Alemanha estavam difundindo exatamente essas coisas não para entretenimento, mas para pavimentar a estrada do maior assassinato em massa da história humana" 2 .

Relatórios do Sicherheitsdienst ("Serviço de segurança", SD) e da Schultze Polizei ("Polícia de proteção") corroboravam os penetrantes efeitos retroativos da produção sobre sua audiência. As violentas demonstrações de antissemitismo eram, de acordo com esses documentos, deflagradas já durante as exibições e se estendiam posteriormente em agressões e atos de vandalismo. Algumas cenas,

\footnotetext{
${ }^{1}$ LEISER, Erwin. Nazi Cinema. Tradução: Gertrud Mander, David Wilson. Nova York: Collier Books, 1974, 154-5.

2 LEISER, Erwin. Op. Cit., 155-6.
} 
recepcionadas como situações abomináveis (em especial a sequência alternada do estupro da virgem com a tortura do seu noivo e a entrada da turba de judeus em Stuttgart), despertavam respostas imediatas. A plateia se manifestava com xingamentos e ameaças: "porco sujo judeu", "seu judeu suíno", "judeuzinho imundo", “atirem os judeus para fora da Alemanha". Exibido regularmente para membros da SS e funcionários dos campos de concentração ou à Wehrmacht, as Forças Armadas, antes de ações programadas nos territórios ocupados, o filme, diz-se, estimulava as disposições antijudaicas de seus espectadores. Esses, após as sessões, sentiam-se mais compelidos aos maus tratos contra os prisioneiros ${ }^{3}$.

Para analistas, críticos e historiadores, Jud Süß triunfou como a mais controversa obra do cinema da época nazista - um filme de ódio tão brutal na sua retórica quanto Der ewige Jude (“O judeu eterno”, Fritz Hipler, 1940), mas muito mais popular. Por sua sofisticação e refinamento, na campanha de preparação do ânimo público à empreitada genocida, a realização serviu como uma privilegiada peça de propaganda. Por isso, viria a fornecer a disoutada evidência para imputação do cinema na consecução do extermínio. Levou seu diretor ao banco dos réus nas cortes de desnazificação do pós-guerra, o único de sua categoria a enfrentar os tribunais sob a acusação de incitação a crimes contra a humanidade ${ }^{4}$.

Na memória de seus espectadores, a produção os teria impressionado ora por sustentar uma representação do passado que creditavam como histórica, ora por enunciar, em termos inequívocos, as depravações supostamente verdadeiras dos judeus. Por conseguinte, a primeira literatura referente a Jud Süß cotejava os indícios dos poderes de alienação, de despersonalização e de reforço dos conteúdos paranoicos da obra sobre sua audiência ${ }^{5}$. Uma parte dos estudos se

\footnotetext{
${ }^{3}$ HULL, David Stewart. Film in the Third Reich: a Study of the German Cinema 1933-1945. Berkeley: University of California Press, 1969, 170; LEISER, Erwin. Op. Cit., 84-5, 152-4; SINGER, Claude. Le Juif Süss et la propagande nazie: la histoire confisquée. Paris: Les Belles Letres, 2003, 190-1 e WELCH, David. Propaganda and the German Cinema 1933-1944. Londres: I. B. Taurus, 2001, 245.

${ }^{4}$ Num notável malabarismo jurídico, Harlan conseguiu se inocentar, desvinculando sua autoria artística dos efeitos nocivos que ela implicava sobre a plateia: para o filme, não obstante, jamais houve remissão. RENTSCHLER, Eric. The Ministry of Illusion: Nazi Cinema and its Afterlife. Cambridge: Harvard University Press, 2002, 149, 166.

${ }^{5}$ GIESEN, Rolf. Nazi Propaganda Films: a History and Filmography. Jefferson: McFarland, 2003, 132 e HULL, David Stewart. Op. cit., 169.
} 
ocupou em mapear alternativamente seus subtextos ou as secretas intenções de Goebbels na imantação do produto final com seu magnetismo fatal. Jud Süß sobreveio estigmatizado pela crença de que bastava o contemplar para ser destruído psicologicamente sob o efeito de seus sórdidos encantos ${ }^{6}$.

Pela qualidade do melodrama, encenado com competência técnica e artística, mas sem nenhum arroubo de grandeza autoral, vista em retrospecto, a impressionante penetração psíquica do filme parece inexplicável7. A despeito de seus atributos, Jud Süß padecia dos defeitos gerais que se podiam reprovar nos filmes do período nazista, particularmente aqueles emplacados por Veit Harlan - um trabalho sumamente bem feito, mas sem surpresas. A técnica não era menos que irrepreensível, os meios lançados em ação eram suntuosos. Carecia, porém, do essencial: não havia gênio. De acordo com seus analistas, a justificativa para as violentas respostas que suas exibições produziam subjazia, então, mais no contexto de radicalização das políticas raciais do regime do que nas suas mensagens subliminares ${ }^{8}$.

O conhecimento referente ao genocídio, ponderou Linda Schulte-Sasse, incentivou no pós-guerra uma leitura enviesada do filme, mecanicamente confinada à marcação antissemita e levando ao segundo plano seus procedimentos textuais. Jud Süß veio ao seu público como parte de um projeto orientado para o extermínio judaico. A admissão de seu terrível propósito, contudo, não implica que seu apelo derivava automaticamente de uma prévia disposição doutrinária. O filme transladava o antissemitismo de Estado para um imaginário estético. Codificava a práxis racista nos termos narrativos do cinema clássico. Daí que mesmo os ideólogos mais renitentes respondessem a ele não como um panfleto, mas como um filme de entretenimento 9.

\footnotetext{
${ }^{6}$ SCHULTE-SASSE, Linda. Entertaining the Third Reich: Illusions of Wholeness in Nazi Cinema. Durham e Londres: Duke University Press, 1996, 47-8.

${ }^{7}$ GIESEN, Rolf. Op. cit., 133.

8 Por isso, se em Berlim e Viena, as sessões precediam demonstrações de entusiasmado antissemitismo, em Paris, onde o filme estreou em fevereiro de 1941, prosperando nas bilheterias por mais de oito meses, as salas de exibição tornaram-se palco de enérgicas demonstrações antifascistas. E, nos cinemas onde persistiu em cartaz, a Resistência francesa efetuou atentados terroristas seletivos contra simpatizantes nazistas. COURTADE, Francis; CADAR, Pierre. Histoire du Cinéma Nazi. Paris: Eric Losfield, 1972, 194-6, 200.

9 SCHULTE-SASSE, Linda. Op. cit., 91.
} 
A obra de Veit Harlan retornava ao ano de 1733 para apresentar a coroação do príncipe regente de Württemberg, o duque Karl Alexander (Heinrich George). Sequioso de providenciar joias em homenagem à duquesa, o governante encaminhou seu camareiro ao gueto de Frankfurt. Dali, o mercador Joseph Süß Oppenheimer (Ferdinand Marian) se fez apresentar à corte em Stuttgart. Astuciosamente, Oppenheimer ganhou a confiança do duque. A proximidade era reforçada porque o comerciante detinha recursos materiais suficientes para satisfazer as demandas de Karl Alexander. Servia como seu assessor de confiança, mecenas da corte e até mesmo proxeneta, desencaminhando e prostituindo donzelas alemãs. Com o apoio de seu secretário, Levy (Werner Krauß), manipulava ardilosamente as superstições, ambições e fantasias do duque. Assumiu a posição de ministro das finanças e, assim, tomou as rédeas do poder. Suas intrigas alienaram o governo aristocrático do povo que se viu abandonado aos desmandos do judeu. Oppenheimer estabeleceu impostos elevados e pedágios nas estradas do ducado. Obteve também a flexibilização das leis que baniam os judeus de Württemberg. Os cidadãos assistiram estupefatos à degradação de seu modus vivendi. Em sua onipotência, o Ministro ousou mesmo cortejar Dorothea (Kristina Söderbaum), a filha de um notável conselheiro da Dieta de Württemberg, o edil Sturm (Eugen Klöpfer). De sua cobiça adveio a rebelião popular. Em represália, Oppenheimer enviou ao cárcere um importante insurgente, o notário Faber (Malte Jäger), noivo de Dorothea. Submeteu-o a violentas torturas. Na inútil tentativa de interceder por ele, Dorothea terminou brutalizada por Oppenheimer. Sozinha e em desespero, ela se lançou às águas de um rio. Sua trágica morte agravou a crise e precipitou a revolução. Nesse brevíssimo interim, o duque também caiu morto, vítima de um ataque cardíaco fulminante. Sem o suporte de Karl Alexander, Oppenheimer foi capturado pelo povo. Julgado com rigor, ele negaria seus crimes, remetendo toda culpa ao regente. Condenado, exposto à humilhação, dependurado numa gaiola, seria, mais tarde, executado por enforcamento em praça pública. Um novo édito baniu os judeus de Württemberg. Ao final, o edil Sturm discursava à multidão, fazendo votos de que a tragédia do ducado permanecesse na memória nacional para 
prevenir, nos tempos futuros, as terríveis maquinações dos judeus ${ }^{10}$.

Da figura real chamada Joseph Süß Oppenheimer sabe-se que habitara várias províncias alemãs, fixando residência em Württemberg no primeiro terço do século XVIII após estabelecer relações com o príncipe Charles Alexander que fez dele seu plenipotenciário, investindo-o das prerrogativas de Primeiro Ministro ${ }^{11}$. Almejando aumentar a arrecadação tributária do ducado, autorizou sucessivos aumentos de impostos, o que aguçou a antipatia popular contra si. Concebeu um programa militar ambicioso: a formação de um exército permanente de doze mil homens a disposição de Charles Alexander. Esses e outros projetos foram abruptamente interrompidos com a morte do Duque. Privado de seu protetor, Süß Oppenheimer tornou-se réu num processo de sedição. Em dezembro de 1737 recebeu a sentença de morte pelos crimes de alta traição, roubo, usurpações, escroqueria e violação de leis. Granjeou uma punição excepcional: foi encarcerado numa jaula de ferro e permaneceu nela dependurado para receber insultos da multidão. Recusou-se a uma conversão tardia ao cristianismo o que, eventualmente, poderia ter-lhe poupado a vida12.

Por ter desafiado o status quo em níveis tão diversos (na política, reforçando

\footnotetext{
10 Parte de um pequeno círculo privilegiado, os judeus cortesãos constituíram uma elite de diplomatas, preceptores, consultores, negociantes e provedores de exércitos, contribuindo para a administração dos Estados independentes do Império Germânico. Devido ao seu acesso privilegiado à nobreza, formavam um segmento atípico. Isentavam-se das severas restrições que pesavam sobre os demais hebreus. Esses se conformavam a regras de confinamento em guetos e nas Judengassen, a ruas de judeus. Quando conseguiam escapar dos decretos de banimento que interditavam sua presença em certos Estados e cidades, eram sujeitos a taxação tributária discriminatória e obrigados a trajar um vestuário que os distinguia dos demais habitantes. Um judeu cortês, ao contrário, podia residir onde bem lhe aprouvesse, era livre nas opções de indumentária e sua riqueza não encontrava rivais entre seus pares. SINGER, Claude. Op. cit., 1213.

${ }^{11}$ SINGER, Claude. Op. cit., 30 e TEGEL, Susan. Jew Süss: Life Legend, Fiction, Film. Londres, Nova York: Continuum, 2011, 11-13.

12 Contra Oppenheimer pesaram os ressentimentos dos protestantes de linhagem luterana pela eleição de um duque convertido ao catolicismo. Seus juízes não hesitaram em lhe atribuir poderes satânicos, sugerindo que impunha sua ascendência sobre o Duque mediante filtros mágicos (dos quais, ademais, faria uso também para corromper damas virtuosas). Onde não encontraram elementos que corroborassem as alegações da acusação, os magistrados imaginaram evidências e as transformaram em provas materiais. Longe de esclarecer a extensão de sua influência nas decisões políticas de Charles Alexander, o julgamento embaralhou as pistas e imantou os fatos num halo de mistificação. SINGER, Claude. Op. cit., 31-5 e TEGEL, Susan. Op. cit., 14-48.
} 
o papel da autoridade central em detrimento das franquias tradicionais: na economia, administrando rigidamente as taxas tributárias: e na religião, evadindo-se do gueto, comportando-se como um gentio e frequentando mulheres cristãs) Süß se transformou numa pequena celebridade póstuma. Sua prisão e execução repercutiram em libelos, panfletos e caricaturas que ganharam as cidades e aldeias, acrescentando novas tonalidades à malfadada saga do "pérfido hebreu". Wilhelm Hauff, um ficcionista de histórias fantásticas, redigiu Jud Süß em 1827, um romance maledicente e difamatório que imputou a Joseph Oppenheimer o epíteto judeu, com forte marcação pejorativa, pelo qual passaria à posteridade. $\mathrm{O}$ sucesso da obra inspirou peças teatrais, estudos acadêmicos e outros romances nos quais as paixões oscilavam. Ora os malfeitos atribuídos a Oppenheimer serviam de argumento às alegações dos antissemitas, ora sua desdita resultava das nefastas maquinações de outros atores pouco recomendáveis: jesuítas, aristocratas e racistas. Enfim, em 1925, Lion Feuchtwanger reabilitou o personagem para denunciar a persistência atemporal das estruturas do antissemitismo e a impossibilidade da simbiose judaico-alemã, produzindo um dos maiores best-sellers de seu tempo Jud Süß13.

O retumbante sucesso do livro levou Süß ao cinema, não como o judeu sinistro, mas o mártir da assimilação. A primeira versão cinematográfica da vida de Oppenheimer surgiu na Inglaterra, em 1934. Jew Süss (O judeu Suss, Lothar Mendes, reintitulado Power nos Estados Unidos) filiava-se a uma corrente de filmes de denúncia contra o antissemitismo que incluía as produções hollywoodianas The House of Rothschild (A casa de Rothschild, Alfred L. Werker, 1934) e The Life of Emile Zola (A vida de Emile Zola, William Diertele, 1937) e também duas realizações britânicas: Loyalties (Basil Dean, 1933) e The Wandering Jew (O judeu errante, Maurice Elvey, 1933) ${ }^{14}$.

\footnotetext{
${ }^{13} \mathrm{O}$ romance encontrou uma recepção extraordinária. Na Alemanha, quarenta mil exemplares foram vendidos nas primeiras semanas após o lançamento, chegando a duzentos mil até sua proscrição em 1933. Traduzido para cerca de trinta idiomas, alcançou uma tiragem de três milhões de exemplares. Transformou uma obscura nota de rodapé na História alemã em um tópico candente, um libelo pelos valores universais da identidade e contra o preconceito étnico. HULL, David Stewart. Op. cit., 161-2 e SINGER, Claude. Op. cit., 36-68.

14 SINGER, Claude. Op. cit., 17, 70-3, 2003, 74-92 e TEGEL, Susan. Nazis and the Cinema. Londres: Hambledon, 2007, 134.
} 
Lançada quando a Alemanha dominava grande parte da Europa, a versão nazista não se baseava na obra de Feuchtwanger. Muito ao contrário, o filme perseguia propósitos bastante distintos. Jud Süß validava a nova cinematografia nacional como um produto à altura das mais prestigiosas realizações de Hollywood. A cinco de setembro de 1940, recebeu sua primeira aclamação no Festival de Veneza. Dedicada especialmente às realizações cinematográficas da Itália fascista e da Alemanha nazista, a mostra contou com a presença de Veit Harlan à frente dos astros Ferdinand Marian, Kristina Söderbaum e Heinrich George. Três semanas mais tarde, estreou no Ufa-Palast precedido de uma noite de gala prestigiada pelo elenco, técnicos do filme e dignitários do regime. Uma ovação encerrou a sessão, seguida das calorosas felicitações de Goebbels a Harlan pela inestimável contribuição artística e política ao patrimônio cultural alemão. Em Berlim, Jud Süß entrou em cartaz em 86 salas. Chegou rapidamente a Leipzig, Breslau, Potsdam, Salzburg, Karlsruhe e Dortmund. Viajou para Viena, Praga, Strasbourg e Luxemburgo. Ao longo de 1941, 4.700 cópias circularam na Alemanha, onde foi visto por dez milhões de espectadores. Recepcionado como um triunfo da arte cinematográfica nacional-socialista, o público referendou o filme com expressivas bilheterias. Nos quinze meses de sua primeira exibição, retornou 5.970.000 RM o que cobriu quase três vezes seu orçamento de 2.000.000 RM15.

Durante a guerra, Jud Süß foi visto por mais de vinte milhões de espectadores em toda Europa. No início de 1941, desembarcou na Finlândia, Dinamarca, Noruega, Holanda, Bélgica, França, Hungria, Bulgária, Romênia, Polônia e nos países bálticos ocupados pela Wehrmacht. Entre maio e agosto, ganhou as telas da Ucrânia, da porção ocidental da União Soviética, da Espanha, Itália, Suíça, Iugoslávia e Grécia. Manifestações antijudaicas acompanhavam essa bem-sucedida jornada e deram início à longeva lenda dos poderes hipnóticos do filme na instigação das disposições racistas de seu público ${ }^{16}$.

\footnotetext{
${ }^{15}$ GIESEN, Rolf. Op. cit., 134, SINGER, Claude. Op. cit., 183-9 e WELCH, David. Propaganda and the German Cinema 1933-1944. Londres: I. B. Taurus, 2001, 244.

${ }^{16}$ Em Viena, após uma sessão, jovens hitleristas apedrejaram um idoso até a morte. Na Bélgica, pilhagens e depredações de lojas e violentos assaltos sucediam as apresentações. Na
} 
A aclamação e o triunfo financeiro de Jud Süß marcavam uma tardia e aguardada apoteose de Goebbels na coordenação da indústria cinematográfica. Até então, ele não demonstrara sua decantada perícia em produzir peças publicitárias simultaneamente úteis ao regime e interessantes para o público. Desde seu advento no RMVP, à exceção dos documentários de Leni Riefenstahl (sobre os quais o Ministro pouco opinou), nada de excepcional acontecera no cinema alemão. "Já se vão cinco anos desde que o Dr. Goebbels encarregou seus diretores de se apressarem e produzirem o Potemkin do nacional-socialismo", zombou em agosto de 1939 George Sadoul. “Ele ainda está esperando"17.

A obra que Goebbels ambicionava, na verdade, já existia muito antes de sua solicitação. Inspirado pelo romance de Wilhelm Hauff, o escritor Ludwig Metzger redigira um roteiro sobre a vida de Süß Oppenheimer em 1922. Na ocasião, disso não resultou nenhum filme e o texto permaneceu engavetado por dezessete anos. Somente em janeiro de 1939, após uma diretiva do Ministro encorajando a aproximação mais ousada da indústria cinematográfica a respeito do problema judaico, Metzger apresentou seu projeto à Terra Filmkunst, uma filial da UFA. Em julho do mesmo ano, a empresa e o escritor firmaram um contrato para tratamento do roteiro, adaptando-o à realização de um filme falado sob direção de Peter Paul Brauer. Mais tarde, Goebbels assumiu pessoalmente o argumento e a produção da obra. Classificou-a como um Staatsauftragfilm, uma realização comissionada pelo Estado e, mais tarde, elevou-a a Staatswichtig, relevante ao Estado. Dispensou Brauer da direção e escalou em seu lugar o polivalente Veit Harlan, ator teatral, roteirista, diretor e produtor cuja carreira entrara em ascensão no Reich ${ }^{18}$.

Tchecoslováquia, em Luxemburgo, na Holanda e na França, também se reportaram manifestações vinculadas ao filme. SCHOEPS, Karl-Heinz. Literature and Film in the Third Reich. Tradução: Kathleen M. Dell'Oro. Rochester, Nova York: Camdem House, 2013, 213 e SINGER, Claude. Op. cit., 21, 189, 191-6.

17 SADOUL, George. A Letter from Paris in KIRSTEIN, Lincoln; LEYDA, Jay; LOSEY, Mary; STEBBINS, Robert; STRASBERG, Lee. Films - a Quaterly of Discussion and Analysis. Nova York: Arno Press, 1968, 92.

18 Em seus tempos de jovem ator teatral, Harlan causara sensação interpretando Friedrich Thiemann na peça teatral Schlageter (Hanns Johst, 1933). Um camarada de armas de Albert Leo Schlageter, o líder dos Freikorps fuzilado pelas tropas francesas por atos de sabotagem e terrorismo contra a ocupação do Ruhr, Thiemann enunciava no palco a célebre prédica fascista: "Quando escuto a palavra cultura, saco logo meu revólver". Do tablado, passou à direção 

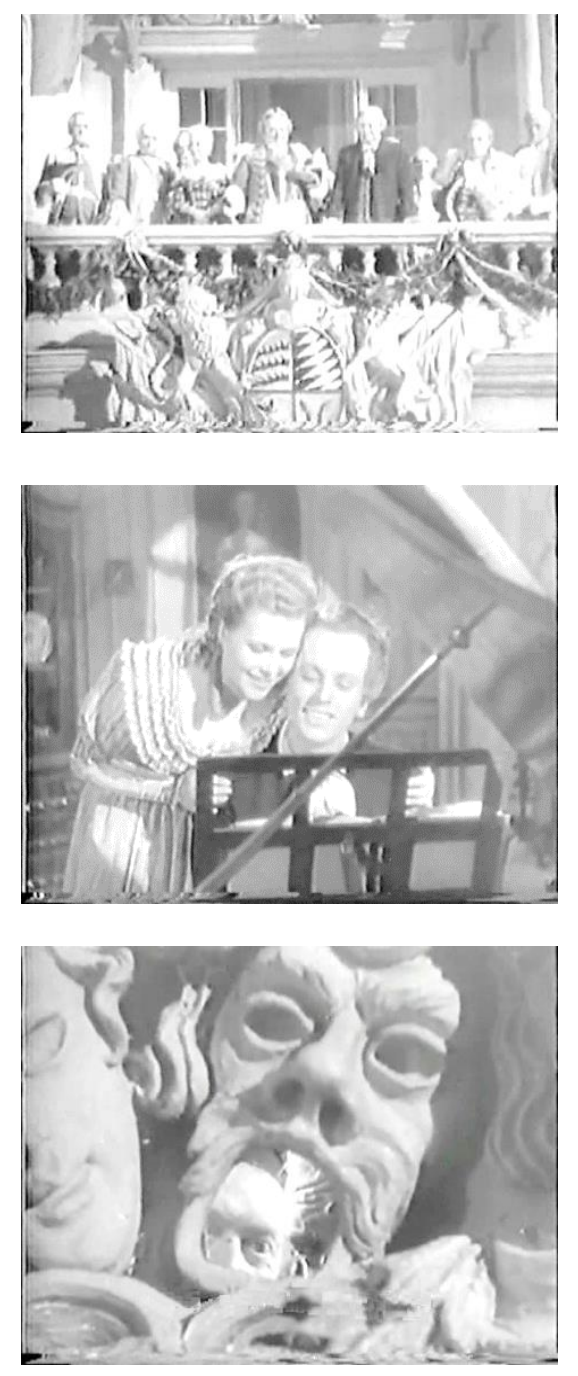

Figs 1.1, 1.2 e 1.3: Heinrich George e Eugen Klöpfer (acima, centro), Kristina Söderbaum e Malte Jäger (meio) e Werner Krauß (abaixo)

Antes e depois da promoção de Harlan ao panteão de artistas sublimes do Terceiro Reich, Jud Süß avultaria como uma obra excêntrica na sua cinematografia. Diferia estilisticamente dos seus demais dramas amorosos ou históricos porque costurava, na sua estrutura, uma tríplice conexão genérica, discernível na forma e no fundo do filme. Caracterizava formalmente três ambientes distintos - a aristocracia católica, a burguesia protestante e o gueto judeu - para transitar, mediante cada um deles, em três categorias cinematográficas: o biopic (filme histórico-biográfico), o melodrama romântico e o filme fantástico expressionista.

Esse fracionamento estilístico era primeiramente vislumbrado na representação visual da obra. Um padrão de luminosidade clara e abundante, infundida em cenários barrocos servia para qualificar os ambientes aristocráticos. Os figurinos resplandecentes reproduziam nos corpos dos atores a nobreza da caracterização do espaço. No sentido oposto, a sobriedade da representação cênica da classe média de Stuttgart oferecia um marcante contraste com os palácios de Karl Alexander. As casas burguesas retinham a marca da compostura

cinematográfica em 1935. Nos dez anos seguintes, rodou vinte filmes que atraíram mais de oitenta milhões de espectadores. Alguns deles como Der Herrscher (Crepúsculo, 1937) e Das unsterbliche Herz ("O coração imortal, 1939) figuraram entre as grandes bilheterias do cinema nazista. Até então um condutor associado a melodramas agradáveis e escapistas, depois de Jud Süß, Veit Harlan se beneficiou com orçamentos privilegiados e produções especialmente comissionadas pelo Estado. Ainda que jamais viesse a se filiar formalmente ao NSDAP, defendeu nas suas obras os valores forjados pela doutrina do Partido. Ganhou o reconhecimento de Goebbels e, assim, ascendeu ao primeiro escalão da nova cinematografia nacional. Tornou-se, nos anos 1940, o mais importante e celebrado diretor da Alemanha. Obteve sucesso vertiginoso com seus obsedantes dramalhões, intensificando o ânimo romântico nas vibrantes cores do Agfacolor: Die goldene Stadt (Cidade da ilusão, 1942), Immensee ("Lago das abelhas", 1943) e Opfergang ("Sacrificio", 1944). TEGEL, Susan. Op. cit., 134-6, 138. 
protestante numa decoração minimalista, apresentada em comedidos esquemas de composição teatral. Muitos tableaux retratavam a família Sturm ora à mesa, ora em torno do piano no qual Faber e Dorothea cantavam sua sentimental canção de amor. Uma circunspecta iluminação geral rejeitava produzir ênfases e detalhes ${ }^{19}$.

Os cenários caracterizados como "judeus", por seu lado, proviam um desconcertante contraponto aos ventilados espaços dos nobres e à lacônica atmosfera burguesa. As cenas nos interiores das casas judaicas eram carregadas de contraste entre o claro e o escuro, com prevalência da obscuridade. Tudo nelas remetia ao desequilíbrio. Atulhados de objetos, os fundos cênicos inferiam uma atmosfera sufocante e malsã. Envergando roupas desleixadas e rotas, os personagens judeus aparentavam desmazelo, má higiene e displicência. Por onde quer que circulasse, a multidão judaica impunha a desordem no quadro, desestabilizando as composições visuais, uma impressão reforçada pelas sinistras monódias vocais apostas à imagem. Esses padrões composicionais desarmônicos transbordavam para dentro dos ambientes aristocrático e burguês tão logo Süß neles penetrava. A referência imediata da desestruturação da sociedade ariana pela invasão semita ganhava reforço na transição das cenas mediante a técnica do fade. De uma sequência dentro da corte a outra no gueto de Frankfurt, o efeito de fusão presentificava, numa semântica estética, a ansiedade fascista de reconhecer seu espaço desaparecendo numa langorosa infiltração judaica. E, no sentido contrário, os cânticos hebraicos se sobrepunham ao início das cenas no palácio e na cidade, engolindo o espaço como uma manifestação infectante num local até então impoluto.

Esse tríplice padrão cênico e as operações de transição que vinculavam três habitats inassimiláveis - a corte, o burgo e o gueto - articulavam uma tripartição do domínio estilístico, o que, de seu lado, sustentava uma constante instabilidade na fixação do gênero ao qual o filme pretendia se filiar. Comercializado como um drama histórico e calcado nas convenções do biopic, passava ao melodrama romântico. Não obstante, residualmente, permitia-se a intrusão das formas do

19 SCHULTE-SASSE, Linda. Op. cit., 75, 90 e SINGER, Claude, Op. cit., 137, 139. 
cinema fantástico de cunho expressionista que dominavam o filme até seu desfecho. Essa figuração tripartite carregava, para o campo do conteúdo, uma percepção de dissensão narrativa a qual, por sua vez, remetia àquela grande fratura histórica que cindira a sociedade alemã em três órbitas culturais divergentes: a católica, a protestante e a judaica. Reproduzia, em operações semióticas cinematográficas, um desejo de totalidade expresso na união das partes cristãs fragmentadas mediante a deleção do inconciliável elemento semita. Por trás da aglutinação de três gêneros fílmicos distintos num compósito intergenérico, movia-se a miragem de uma síntese do povo num Estado e numa sociedade totais.

\section{$\underline{\text { Biopic }}$}

“Os eventos representados nesse filme são baseados em ocorrências históricas", informava o crédito de abertura, pelo que Jud Süß reclamava, daí em diante, uma criteriosa caracterização dos fatos, resultado de vastas pesquisas (presunção de modo algum singular no cinema da época nazista). Disfarçada sob as convenções do filme histórico e do biopic, a obra se insinuava como uma acurada e imparcial representação num jogo de rebatimento entre ficção e documentação ${ }^{20}$.

No cinema do período fascista, a maleabilidade do biopic precocemente o qualificou como subgênero preferencial para a publicidade política ${ }^{21}$. Duas linhas

\footnotetext{
20 No sistema de produção industrial, o biopic prosperou como um subgênero facilmente assimilável às categorias cinematográficas mais abrangentes: o melodrama, o épico, o filme criminal, o capa-espada. As panorâmicas preenchidas pela multidão, a massa frenética capturada em breves quadros, a montagem paralela, as cenas de tribunais ou de julgamentos públicos e o tema do "preço do sucesso", muitas vezes tratado como uma problemática megalomania do protagonista, perfaziam os motivos centrais do gênero. Mais do que a restituição verídica de uma biografia, a fantasia invocada pelo biopic revolvia em torno da luta pela fama, pela fortuna e pelo sucesso cuja gratificação atingia a plenitude no momento em que o personagem se singularizava diante dos anônimos na turba. Era, então, consagrado ou destruído pela horda. A dinâmica implacável do narcisismo desafiava as limitações do princípio da realidade e o resultado desse embate dependia da conformidade do personagem ao circuito de valores ideológicos vigentes. NEALE, Steve. Genre and Hollywood. Londres e Nova York: Routledge, 2009, 63-5 e RENTSCHLER, Eric. Op. cit., 150-1.

${ }^{21}$ COURTADE, Francis; CADAR, Pierre. Op. cit., 35-6.
} 
de força balizavam, então, o filme histórico-biográfico: o Geniusfilme, o "filme de gênio" e o filme de ódio. A primeira corrente afirmava o sacrifico pessoal de um grande homem que, pelo seu gesto de renúncia, validava em tempos remotos os propósitos cultivados pelo nacional-socialismo na contemporaneidade ${ }^{22}$. Envolvia uma mistura heterogênea que tomava uma figura histórica de vulto e, sobre ela, apunha uma roupagem de época e as perorações do Kampfzeitfilm²3. Na edificação do seu público, esse gênero eviscerou o passado para revelar, em vários momentos da História nativa, os prelúdios do nacional-socialismo. Por seus feitos de bravura reais ou inventados em benefício da consciência comunitária, grandes e pequenas figuras recebiam a investidura de heróis da nação. Frederico II, rei da Prússia entre 1740 e 1786 (com quem Hitler era reiteradamente identificado), principiou a modalidade e em torno de sua memória organizou-se um ciclo próprio de filmes ${ }^{24}$. O Geniusfilm proclamava o patriotismo e o valor supremo da germanidade, contrapondo fantasias persecutórias à glorificação de uma Alemanha atemporal, encabeçada pelos paladinos da nação ${ }^{25}$.

22 SCHULTE-SASSE, Linda. Op. cit., 106-9.

${ }^{23}$ Os Kampfzeitfilme, "filmes da época da luta" congregavam obras cinematográficas realizadas nos anos iniciais do regime fascista, ambientadas durante a República de Weimar, que retratavam o despertar da consciência de um protonazista e a fundação do partido nos turbulentos anos de luta entre ultranacionalistas e comunistas. Relatavam as recentes sagas dos milicianos martirizados na época de Weimar, Herbert Norkus em Hitlerjunge Quex (Mocidade Heroica, Hans Steinhoff, 1933) e Horst Wessel em Hans Westmar, einer von vielen (Franz Wenzler, 1933). Mais tarde, os biopics almejariam a reescrita biográfica em busca de fascistas exemplares mesmo em épocas mais remotas como o oficial de cavalaria na Primeira Guerra Mundial, Carl Friedrich Freiherr von Langen em ... reitet für Deutschland (“... cavalga pela Alemanha”, Arthur-Maria Rabenalt, 1941) e o prefeito antissemita de Viena, Karl Lueger e o pangermanista Georg von Schönnerer em Wien 1910 ("Viena, 1910", E. W. Emo, 1943). TEGEL, Susan. Op. cit., 201-2.

${ }^{24}$ Esse Friedericusfilme já desfrutava de imenso prestígio no cinema de Weimar, congregando sete produções, todas estrelados pelo mesmo ator, Otto Gebühr. Frederico renasceu na era nazista em três grandes realizações - Der alte und der junge König (Alma mascarada, Hans Steinhoff, 1935), Friedericus, der alte Fritz ("Frederico, o velho Fritz", Johannes Meyer, 1936) e Der große König (O grande rei, Veit Harlan, 1942) - que coadunavam lances episódicos da vida do monarca e de suas conquistas militares aos slogans publicitários do regime. Invocavam a infalibilidade da liderança, a persistência diante das adversidades e a galhardia da fé cega nos imperscrutáveis desígnios da autoridade estatal. COURTADE, Francis; CADAR, Pierre. Op. cit., 59-68.

${ }^{25}$ Notadamente Bismark em Bismark (1940) e Die Entlassung ("A exoneração", 1942), ambos dirigidos por Wolfgang Liebeneiner, o médico Robert Koch, der Bekämpfer des Todes (Robert Koch, 1939) e o pioneiro do colonialismo Ohm Krüger (1941), ambos de Hans Steinhoff, seguido de outro aventureiro, Carl Peters (Herbert Selpin, 1941), além do inventor do ovo de Nuremberg, Peter Henlein em Das unsterbliche Herz ("O coração imortal", Veit Harlan, 1939), Friedrich Schiller, der Triumph eines Genies ("Friedrich Schiller, o triunfo de um gênio", Herbert Maisch, 1940), Ewiger 
No sentido oposto ao filme do gênio, o biopic subsidiava também o cinema de ódio com suas impressionantes deformações da História para denegrir os inimigos eletivos da nação. Ali, a crueldade dos poderes estrangeiros inspirava fantasias sádicas (por vezes centradas no martírio de heroínas arrastadas pelo turbilhão dos tempos) ${ }^{26}$. Dessas variadas experiências progrediria o biopic racista dos anos 1940. Por determinação de Goebbels, o rótulo “antissemita” não poderia vir apenso a esse segmento de realizações. As campanhas publicitárias e a crítica se referiam a elas como "dramas históricos" que retratavam objetivamente os acontecimentos, livres de disposições tendenciosas, preocupadas apenas em estabelecer os fatos ocorridos ${ }^{27}$. Diferiam, por isso, dos primeiros filmes antissemitas da década de 1930. Esses não pretendiam ocultar, sob o entretenimento ligeiro, sua solicitação racista. Na pobreza de seus meios, ofereciam-se como uma nova categoria de passatempo pelo qual o imaginário político do inimigo do Estado provia uma multiplicidade de "outros" com os quais o espectador podia se divertir. Retratados ali como incorrigíveis idiotas, os judeus estereotipados, ainda que inescrupulosos, não eram páreo para o astucioso nórdico ${ }^{28}$. Foi somente a partir de 1940 que a segunda corrente de

Rembrandt (Hans Steinhoff, 1941), a tragédienne Caroline Neubar em Komödianten ("Comediantes", Georg Wilhelm Pabst, 1941), o arquiteto dos reis Andreas Schüller (Herbert Maisch, 1942), Mozart em Wen die Götter Lieben ("Quem os deuses amam", Karl Hartl, 1942), Diesel (Gehard Lamprecht, 1942), o inventor do submarino, Wilhelm Bauer em Geheimakte WB I ("Dossiê secreto WB I", Herbert Selpin, 1942) e Paracelsus (Georg Wilhelm Pabst, 1943). COURTADE, Francis; CADAR, Pierre. Op; cit., 74-107 e PETLEY, Julian. Capital and Culture: German Cinema 1933-45. Londres: British Film Institute (BFI), 1979, 139.

${ }^{26}$ Em Das Mädchen Johanna (Santa Joanna D'Arc, Gustav Ucicky, 1935), por exemplo, a perfídia dos franceses e a brutalidade da Inquisição contra Virgem de Orleans remetia à francofobia e ao anticatolicismo nazista. Já os sete desventurados anos de reinado de Mary Stuart e sua decapitação, tramada por uma tirânica Elizabeth I em Das Herz der Königin ("O coração da rainha", Carl Froelich, 1940), atualizavam junto ao público os intermitentes sentimentos de anglofobia cultivados entre os ideólogos nazistas. COURTADE, Francis; CADAR, Pierre. Op; cit., 68-71.

${ }^{27}$ LEISER, Erwin. Op. cit., 76; RENTSCHLER, Eric. Op. cit., 96 e WELCH, David. Op. cit., 239.

${ }^{28}$ Muito pouco da empedernida luta racial ganhou espaço nas telas do Reich durante os anos 1930. Mesmo depois dos judeus adquirirem a envergadura de inimigos número um da Alemanha, a retórica antissemita raramente mereceu destaque nas produções de entretenimento (esse desconcertante fenômeno eludiu seus analistas, os quais consideraram que as complicações particulares da produção cinematográfica dificultassem a política de choque de informações pela qual a propaganda totalitária se fazia saber). $O$ gênero antissemita somente estreou nos cinemas do Reich entre dois grandes eventos: as arruaças de 10 de novembro de 1938 (mais tarde referidas como Kristallnacht) e o dia 12 de outubro de 1939, quando se impôs aos judeus residentes na Áustria e na Tchecoslováquia o uso compulsório de uma estrela estampada no vestuário. À 
antissemitismo no cinema desbancou a sátira e estabeleceu no judeu um adversário à altura da raça ariana ${ }^{29}$.

Nas múltiplas versões biográficas em torno do cortesão de Württemberg, a distância entre Joseph Oppenheimer e o dito Judeu Süß pendeu episodicamente de acordo com o ponto de vista ideológico que o tomava como assunto. Mas, fosse qual fosse o ângulo de incidência, sua história era revolvida para sempre produzir um mesmo argumento: a impossibilidade das relações entre cristãos e judeus. Enquanto filme biográfico, Jud Süß dava seguimento a essa tendência. Recuperava, nessa mesma chave, um contexto preciso para com ele camuflar uma querela religiosa, travestindo-a em disputa política.

Pela caracterização de Jud Süß, no ducado de Württemberg se divisava um Estado interrompido pelas disputas internas. A fragilidade regimental que abriu os portões de sua capital a Oppenheimer comportava uma dupla fissura, política e religiosa. Os dois âmbitos se imiscuíam, confundiam-se e rebatiam um no outro $^{30}$. Historicamente, rancores religiosos haviam agravado as disputas entre os luteranos de Württemberg e Charles Alexander desde seu advento em Stuttgart. Numa crescente querela, da qual Oppenheimer não participou de modo algum, o Duque, sob instigação dos jesuítas, voltou-se contra a Dieta (assembleia legislativa, que, à época, era segmentada em três seções: eleitores, príncipes e cidadãos), a qual resistia à imposição de um regime militar no

exceção de Pettersson \& Bendel (uma comédia sueca produzida em 1933), até 1938 nenhuma realização circulando no Reich viria a se referir, direta ou indiretamente, aos judeus - não havia nos filmes vestígios da crescente radicalização das políticas raciais e da perseguição antissemita. Posteriormente, o punhado de obras apresentados sob o slogan do conluio judaico contra os arianos coincidiu com as sucessivas etapas da Solução Final. Integraram-se numa curta propaganda de larga escala, deflagrada em várias plataformas midiáticas, delineada não apenas para aguçar a disposição racial das plateias, mas para fazê-las menos resistentes às respostas extremas do regime contra o problema dos judeus alemães. Por isso, antes de Jud Süß, personagens judeus apareceram no plano de fundo de duas comédias de 1939. Leinen aus Irland ("Linho da Irlanda", Heinz Helbig) e a farsa musical Robert und Bertran ("Robert e Bertran", Hans Heinz Zerlett). Na alvorada da Segunda Guerra Mundial e às vésperas da institucionalização do programa genocida nos campos de concentração, a posição e o espaço cinematográfico dos judeus experimentaram uma súbita mudança. Abandonaram a periferia da ação para serem atirados ao centro do drama do que adveio a sua apoteose nos grandes filmes de ódio da década de 1940. GIESEN, Rolf. Op. cit. 120: LEISER, Erwin. Op. cit., 74-7: SCHULTE-SASSE, Linda. Op. cit., 237, 238-40: TEGEL, Susan. Op. cit., 106-12, 125, 193-6: WELCH, David. Op. cit., 238.

${ }^{29}$ RENTSCHLER, Eric. Op. cit., 152-3.

${ }^{30}$ SCHULTE-SASSE, Linda. Op. cit., 51. 
ducado. A medida tendia a neutralizar os ordenamentos locais franqueando a imposição do catolicismo, a religião do governante, a um território eminentemente protestante ${ }^{31}$. Sem nunca mencionar a cisão de crença que opunha a Dieta burguesa, conservadora e protestante à realeza aristocrática, reacionária e católica, Jud Süß remanejava os fatos históricos, omitindo o projeto de centralização religiosa de Charles Alexander. Adulterava o propósito do regente de fixar seu credo sobre Württemberg e implicava Oppenheimer numa conspiração palaciana para levar a termo um golpe de Estado ${ }^{32}$.

Evitando o escorregadio plano das lutas sociais, o filme transplantava o embate político e religioso para o âmbito das disputas raciais. Nesse registro, da figura (católica) de Karl Alexander não emanava a ordem. Seu mandato era, contrariamente, o veículo da conturbação. Sua inclinação ao deboche e à libertinagem contrastava com a compostura, a frugalidade e a disciplina (protestante) da Dieta. Nos desregramentos do Duque, desembarcando em meio à esbórnia e à licenciosidade em Stuttgart, o espectador podia antever as iminentes transgressões que os judeus ali cometeriam ${ }^{33}$. A defasagem entre a aristocracia corrompida e a burguesia virtuosa, respectivamente assinaladas nos domínios do catolicismo e do protestantismo, somente podia ser dissipada pela narrativa como um problema de fundo mediante a invocação de um inimigo comum a ambas, o judeu. Esse se interpunha entre os dois segmentos da cristandade, alienando-os ao ponto da autoaniquilação.

No período histórico da Württemberg de Charles Alexander e Süß Oppenheimer, não havia propriamente nenhum Estado centralizado e independente e nem mesmo um poder governamental superior. Costurado nos vagos compromissos de vassalagem e suserania com o Papa católico pela Bula Dourada de 1356 e emendado com a Dieta de Augsburg de 1555, o Sacro Império Romano Germânico era um acolchoado de territórios em permanente conflito,

\footnotetext{
${ }^{31}$ LEISER, Erwin. Op. cit., 81-2.

32 SCHULTE-SASSE, Linda. Ibid.

33 SCHULTE-SASSE, Linda. Op. cit., 54-5.
} 
incapaz de conter as forças centrífugas que desafiavam a centralização estatal. Naquele contexto, a denominação Alemanha remetia a um território da Europa cujo estatuto político flutuava de acordo com a conjuntura. A elasticidade da denominação correspondia à imprecisão da unidade à qual ela aludia. Essa relíquia dinástica da Idade Média, uma fração residual e mal remendada do Império Romano do Ocidente, estruturava-se em torno de linhagens de imperadores impotentes e das Dietas. Nada pertinente ao significante “Alemanha" exprimia alguma equivalência com as figuras dos demais Estados europeus como a Inglaterra, a França ou a Espanha ${ }^{34}$.

Assombrada por uma persistente memória de dispersão, mais do em que qualquer outra dimensão da realidade social, era na religião, e não na política, que ainda persistia, em 1940, o espectro dessa disjunção. Pelos séculos afora, a diferença confessional recortou a história social alemã em turbulentas disputas. Erodiu as bases de formalização de um Estado nacional dando prosseguimento a uma clivagem originária e a um irrealizável desejo de totalidade. Sola fide. Somente a fé sustentava a miragem de uma nação integral.

"Somente a fé" foi o mote do protesto de Lutero o qual, mais tarde, serviu de plataforma doutrinária para o cisma religioso que derrubou a Idade Média ${ }^{35}$. Lutero obrou sobre as pregações do apóstolo Paulo para delas extrair um credo de justificação. Paulo recorrera, em suas epístolas aos romanos, 22 vezes ao verbo justificar, para fundar as bases de sua teologia. Por justificação, referia-se a uma anistia mística das máculas pregressas que resgatava o crente à condição de justo ${ }^{36}$.

Da doutrina paulina da graça pela justificação emanaram as 95 teses com as

\footnotetext{
34 STEINBERG, S. H. The 'Thirty Years War' and the Conflict for European Hegemony 1600-1660. Londres: Edward Arnold Publishers, 1966, 19, 22-3, 99, 107.

${ }^{35}$ ELTON, Geoffrey Rudolph. A Europa durante a Reforma 1517-1559: as Reformas Religiosas. Lisboa: Editorial Presença, 1982, 14.

36 "O justo viverá pela fé" (Romanos 1:17; Gálatas 3:11), pois a justiça emanou de Deus, independentemente das leis e dos profetas (Romanos 3:28 e 6:14). Fez-se reconhecer em Cristo, sem distinção e para todas as pessoas que creem. Essas foram justificadas pela graça redentora. A misericórdia divina lhes cancelou os pecados (Romanos 3:21). Por meio de sua morte, Cristo pagou o resgate exigido por Deus para emancipação dos homens e libertou o crente. A expiação dos delitos remia a culpa, limpava a consciência e salvava a vida de quem aceitava o gesto sacrificial do Messias. Nesse momento, o crente nascia de novo.
} 
quais Lutero solapou as principais bases ideológicas da Igreja Romana. A Alemanha propriamente dita nasceu nessa revelação teológica e, doravante, viveu em permanente aflição. Pois o ímpeto reformista logo escapou ao controle de seus artífices. Conclamando à restauração do Evangelho, o luteranismo pressupunha a restituição do povo perante os poderes terrenos. Ainda que em suas preleções Lutero jamais houvesse solicitado a dissolução da ordem secular, suas ideias desencadearam paixões violentas nas massas. A fé na exclusividade espiritual dos crentes, na salvação milenarista e no advento do Reino dos Céus pela prévia erradicação dos iníquos desvelou a vocação para uma intolerância muito mais extrema do que a de qualquer igreja institucional. Adveio, daí, uma era sombria de secessões religiosas e dissidentes radicais - Münzer, Zuinglio, Calvino, Felix Manz - pregando a salvação dos pobres conquanto se erguessem frente aos opressores. Em meio a sucessivos banhos de sangue, acreditavam que o messias anunciaria seu retorno. Desde então, no território alemão, abundavam as marcas de uma tripla fragmentação religiosa: a papista, a reformadora e a sectária ${ }^{37}$.

"A Alemanha é o país das alucinações", sentenciou Goethe ${ }^{38}$. Pois sua história foi uma gradação de violência e rupturas que sempre se sobrepunham ao desejo de unificação. Ao invés de reatar os laços comunais, as sucessivas novas religiões aprofundavam as cissuras e radicalizaram as posições do que resultou um Estado inacabado, cindido e traumatizado. $O$ turbulento prelúdio da Reforma anunciava uma era de tolerância nas profissões de fé. O efeito imediato da contestação, contudo, foi bem diverso. Houve um recrudescimento dos particularismos, a vulgarização das perseguições, o incentivo aos ódios e a proliferação de variadas ondas de fanatismo. A Reforma incentivou o extremismo, favoreceu posições radicais e destruiu a possibilidade de um ambiente de debate teológico. Rompeu, decerto, com o monopólio católico da fé ocidental: deflagrou, porém, uma batalha religiosa na qual nenhum dos contendores poderia triunfar ${ }^{39}$. Consequentemente, a Alemanha se transformou

\footnotetext{
${ }^{37}$ ELTON, Geoffrey Rudolph. Op. cit., 47-9, 73-5, 81-2, 143.

38 GOETHE, Johann Wolfgang. Lamartine. Porto Alegre: Editorial Curiosidade, 1942, 22.

${ }^{39}$ ELTON, Geoffrey Rudolph. Op. cit., 52, 224.
} 
numa babel religiosa em que os católicos confrontavam os luteranos, os luteranos combatiam entre si e, mais tarde, os calvinistas batalhariam contra todos. Mais do que em qualquer lugar, ali o enigma da luta confessional destruía qualquer ilusão de um ecumenismo universal ${ }^{40}$.

Em 1648, um arranjo de acordos ad hoc erraticamente celebrados nas cidades de Osnabrück e Münster na Westphalia colocaram fim ao último grande conflito religioso alemão, o qual se estendeu por toda a Europa, a Guerra dos Trinta Anos. A Paz de Westphalia, consagrada como a pedra angular do equilíbrio europeu, estabeleceu o unânime critério de que o país deveria constituir uma confederação de Estados independentes, integrados por um tênue pacto federativo. Os tratados cindiram o espaço alemão, obstruíram a aspiração centralista, reforçaram as tendências federalistas e reconheceram a soberania dos Estados membros. Estabeleceram as diretrizes para erradicação das tensões religiosas e para consecução de uma paz duradoura às custas da permanente mutilação da nação ${ }^{41}$. À exceção dos alemães, esse argumento pareceu suficiente para todos os poderes europeus. "A razão de Estado é uma fera maravilhosa”, comentou um observador dos acordos, "pois ela afugenta todas as outras razões". Do que, por conseguinte, a guerra religiosa prosseguiu seu curso por outros meios ${ }^{42}$.

Um dos curiosos procedimentos estéticos emoldurados pela articulação ficcional de Jud Süß consistia precisamente no encadeamento sintético em blocos compactos de longos processos da história político-religiosa alemã. A produção sequestrava um episódio factual, os quatro anos em que Joseph Süß Oppenheimer permaneceu à frente da administração financeira de Württemberg, para fazer dele uma narrativa modelar. Construía uma fábula que imiscuía fatos e ficção pela qual restituía à sociedade uma desejada completude originária. Jud

\footnotetext{
${ }^{40}$ ELLIOT, J. H. A Europa dividida: 1559-1598. Tradução: Conceição Jardim e Eduardo Nogueira. Lisboa: Editorial Presença, 1985, 11-24, 32, 176-80: e STEINBERG, S. H. Op. cit., 23 e PARKER, Geoffrey (ed). The Thirty Years' War. Londres e Nova York: Routledge, 1987, 11-22, 19.

${ }^{41}$ PARKER, Geoffrey. Op. cit., 160-5, 186-93 e STEINBERG, S. H. Op. cit., 1-3, 75-85, 103-16.

42 PARKER, Geoffrey. Op. cit., 193-6.
} 
Süß não se oferecia como uma alegoria - seus códigos pertenciam à tradição do cinema clássico narrativo - mas funcionava perfeitamente como tal. Numa forma dramática convencional, o filme lograva acomodar-se às exigências do entretenimento e traduzir pari passu todos os capítulos da cisão política e religiosa da Alemanha, da Reforma luterana às Leis de Nuremberg.

O evento inaugural da trama, a carnavalesca entrada da comitiva de Karl Alexander para sua coroação em Stuttgart, figurava justamente o momento da ruptura religiosa. Cenicamente, os quadros fixavam a malaise de sua bufa presença, opondo-a às tépidas figurações dos súditos burgueses. Sem mencionar explicitamente a adversidade de credo em nenhum momento, as representações visuais demarcavam com extraordinária precisão a rachadura doutrinária. $\mathrm{O}$ ruidoso fausto, a empáfia e as maneiras aviltantes do novo regente participavam do improbo imaginário que a perspectiva luterana imputava ao modelo romano de cristandade. Referendava, em códigos visuais, a aversão dos pangermanistas à figura do "príncipe estrangeiro", cujo primeiro modelo era o próprio Papa. Trazia para dentro da cena a memória da antipatia aos laços de solidariedade entre a Igreja católica e as monarquias antinacionalistas. Inferia o status de Estado dentro do Estado com o qual o Vaticano sedimentara sua hegemonia à distância. Reinscrevia em letras invisíveis e ao contrário o slogan fascista Lors von Rom ("livre de Roma") 43 .

Subitamente, a trama interrompia essa trajetória para invocar ao primeiro plano seu protagonista, Süß Oppenheimer, o qual, doravante, assumia o ponto de vista narrativo. $\mathrm{O}$ aparecimento desse terceiro elemento aguçava os antagonismos entre o príncipe cristão e os burgueses luteranos. Süß instaurava, com sua magnética presença, uma estética desestabilizada e, com ela, expandia o foco da ação conflituosa. Tornava-se, por isso, o destinatário das hostilidades cujo conteúdo religioso não passava ao largo da enunciação. “Ao menos ouça o conselho de Lutero", advertia ao Duque o conselheiro Sturm. "Ele disse: “Tenha em mente, caro cristão, que não tens um inimigo pior que o judeu. Este é meu

\footnotetext{
43 STEIGMANN-GALL, Richard. The Holy Reich: Nazi Conceptions of Christianity, 1919-1945. Cambridge: Cambridge University Press, 2003, 62, 84.
} 
conselho: que se devem deitar ao fogo suas sinagogas e escolas. Deve-se erradicar seus ensinamentos do Talmude que traz tantas mentiras. E eles devem ser proibidos de praticar a usura...'". Do que os procedimentos de organização da narrativa aduziam a perpetuação da ruptura político-religiosa como obra da perfídia e do oportunismo judaicos. As lutas sociais que seguiam ao advento de Oppenheimer remontavam ao grande ciclo de guerras internas nas quais as confissões divergentes da cristandade disputaram a linha de frente do poder. A alocação indevida do judeu cortês ao centro do embate permitia a fixação de um inimigo schmittiano comum a católicos e luteranos ${ }^{44}$. Sua posição na narrativa dissipava as implicações fratricidas da rivalidade que paralisava Württemberg e, por extensão, a Alemanha. Todas as operações subsequentes da ficção visavam ao reforço desse conteúdo, culminando no desmascaramento e no holocausto do conspirador.

O desfecho - a sequência de enforcamento de Süß e o anúncio das leis de expatriação dos judeus de Württemberg - sugeria que a fissura fora purgada pela extinção do antagonista. A solução cênica para o encerramento de uma tradição de divergências fixava a noção de afirmação soberana pela suspensão de um segmento social, o que cumpria a almejada unidade. Pois não somente bastava eliminar o judeu para dispersar o miasma do cisma. Após a morte de Karl Alexander, a aristocracia - e, por extensão, a fração católica - também

\footnotetext{
${ }^{44}$ Carl Schmitt reduziu à relação amigo-inimigo a dimensão própria do poder político. Não se referia nem às rivalidades privadas, nem às disputas partidárias. A fundamental oposição amigoinimigo inexistia em qualquer outro campo além do político porque sinalizava o momento extremo do conflito, a luta de vida e morte, o combate de negação ao adversário. Indicava a condição da antítese onde o Estado incidia sua soberania para extirpar a rivalidade, decidindo, se necessário, pela excisão de uma das partes. Por esse expediente retórico, Schmitt buscava delimitar a fronteira que separava a luta política da matança arbitrária. Condenava, portanto, a guerra absoluta (e, por extensão, a ulterior extrapolação antissemita de suas teorias pelos nazistas) porque essa degradava o adversário para além de seu estatuto político, imputando-lhe qualificações morais que justificavam sua completa aniquilação. Infelizmente, Schmitt proveu uma hermenêutica ao racismo niilista que, incapaz de produzir sínteses, voltava-se cada vez mais para a autodestruição. Tomado arbitrariamente pelo fascismo, o binômio amigo-inimigo ensejou a variante torta do nacionalismo nazista que estendia a fratura endógena da Alemanha à cena internacional, transplantando em toda parte e em todas as épocas uma guerra racial nativa. SCHMITT, Carl. The Concept of the Political. Tradução: George Schwab. Chicago: University of Chicago Press, 2007, 25-8, 32, 36 e BALIBAR, Etienne. Racisme et nationalisme in BALIBAR, Etienne; WALLERSTEIN, Immanuel. Race, nation, classe: les identités ambiguës. Paris: Éditions La Découverte, 1990, 73-5.
} 
desaparecia da cena. Sturm, enquadrado num travelling panorâmico por um plongée que se encerrava num grande close-up, anunciava o novo édito de banimento dos judeus. A sequência implicava que a permissividade católica perdera lugar ao rigor protestante e esse, doravante, regulamentaria as relações de poder.

$\mathrm{Na}$ Alemanha, poder e religião participaram de um mesmo substrato conceitual. A História nacional foi uma longa narrativa na qual os dois âmbitos se contaminavam sem cessar - a cesura numa instância, por conseguinte, prontamente reverberava na outra ${ }^{45}$. Daí que a orientação da narrativa e a opção estética no encerramento de Jud Süß atestassem que, em 1940, ainda persistiam os esforços de engendramento da unidade política ao redor de uma denominação teológica nacional. Para tanto, os preceitos luteranos ofereciam uma plataforma de ancoragem ideológica ${ }^{46}$. Os doutrinadores nazistas cedo perscrutaram nos enunciados do protestantismo originário um parentesco com anseios que lhes

\footnotetext{
45 Uma sólida tradição teórica germânica corroborava a intermitente dependência do domínio mundano em relação ao sagrado. De Hans Kelsen a Eric Voeglin, articuladores contemporâneos ao fascismo discerniram, sob a tóxica revivescência da comunidade política em sua modalidade nacional-socialista, não uma irrupção da ordem religiosa na esfera profana, mas a imprópria articulação das relações do direito e do poder pelo crivo do sagrado. Seu mais notável apologista, Carl Schmitt, durante a alvorada do fascismo europeu, contemplava no Estado constitucional um deísmo sem deus, a metafísica que aboliu o milagre, a religião depurada da fé. Ao seu ver, a política não assinalava uma perfeita continuidade entre conceitos de fé e poder, mas uma modulação da política em índices semânticos da esfera religiosa. Qualificando a potência estatal como originária e absoluta, vigendo além dos limites racionais do sujeito legislante, o deísmo schmittiano não estava muito longe do dogma fundador nazista que tornava divinos os poderes políticos desse mundo. KELSEN, Hans. A democracia. Tradução: Ivone Castilho Benedetti, Jefferson Luiz Camargo, Marcelo Brandão Cepolla, Vera Barkow. São Paulo: Martins Fontes, 2000, 204-11, SCHMITT, Carl. Political Theology: Four Chapters on the Concept of Sovereignty. Tradução: George Schwab. Chicago: Chicago University Press, 2005, 36-7 e SCHMITT, Carl. State, Movement, People: the Triadic Structure of the Political (1933) / The Question of Legacy (1950). Tradução: Simona Draghici Corvallis: Plutarch Press, 2001, 3-11 e VOEGLIN. Eric. As religiões políticas. Tradução: Teresa Marques da Silva. Lisboa: Vega/Passagens, 2002, 21, 26, 69, 82.

${ }^{46}$ Simpatizantes ao nazismo pertenciam a todas as classes sociais. Distribuíam-se em todas as faixas etárias e residiam em todas as regiões da Alemanha. Mas, ainda que dispersos nos mais variados setores da sociedade, seus militantes e eleitores provinham amplamente de contextos protestantes. A predileção religiosa tendia a determinar a inclinação ao nazismo com ênfase muito mais acentuada do que a posição econômica, o grau de instrução ou qualquer outro índice de segmentação social. Enquanto os redutos católicos remanesceram alheios aos argumentos do nacional-socialismo, a apologia a temas protestantes atraiu apoio ao NSDAP de veteranos, estudantes, operários, intelectuais, etc. Em 1932, nas áreas de maioria católica, o voto nazista remanesceu abaixo de 10\%: nas regiões de preferência protestante, ao contrário, oscilou para além de 60\%. MANN, Michel. Fascistas. Tradução: Clóvis Marques. Rio de Janeiro: Record, 2008, $212-$ 4, 253-7.
} 
convinham nas suas pregações: a precedência do heroísmo de Cristo sobre o preceito da humildade e a marca da predestinação contra o universalismo, por exemplo. Enfatizando esses aspectos da fé, se não rejeitavam o cristianismo in toto, distanciavam-se da sua modalidade enunciada em Roma ${ }^{47}$.

$\mathrm{Na}$ predileção pela religião protestante, o nazismo afirmava o particularismo alemão. Recordava que a Reforma fora uma reação germânica contra uma cristandade desenraizada e os poderes remotos do Vaticano. As exortações paulinas de que Lutero lançou mão para imputar os judeus no assassinato de Cristo e nos padecimentos dos primeiros cristãos, ademais, assentavam-se bem às prédicas antissemitas do regime ${ }^{48}$. Durante a vigência do nazismo, de tempos em tempos, vozes se ergueram para conclamar a unificação de denominações menores numa fortalecida igreja protestante do Reich, a Bund für deutsche Kirche (BdK, Liga para a Igreja alemã). Como muitos nacionalistas que os antecederam, os nazistas diagnosticavam na secessão religiosa um perigoso empecilho à almejada unidade política do Volk. No apelo por uma religião sincrética, infundida apenas das noções mais elementares do cristianismo, o regime tentava então emplacar um programa de fé movido pela precedência do dogma da unidade nacional sobre os particularismos confessionais. Procurava um rito mínimo que agradasse indistintamente católicos e protestantes. Aspirava por uma Cristandade Positiva - nem a da Reforma, nem a da Contra-Reforma - a qual dispusesse o crente às noções gerais de um dogma despido das formalidades eclesiásticas. Contra a polarização propugnava o Überkonfessionalismus, o supraconfessionalismo, uma prática religiosa pautada em elementos de síntese da qual adviria um cristianismo ideal e espiritualista aposto acima das confissões. Convidava a uma renovação religiosa nacional na qual católicos e protestantes se reuniriam num mesmo credo

\footnotetext{
47 STEIGMANN-GALL, Richard. Op. cit., 112.

${ }^{48}$ Lutero rejeitou violentamente o que definia como a apostasia judaica. Com uma violenta linguagem, seu tratado Sobre os judeus e suas mentiras qualificava os hebreus como os piores entes da criação. Legou para a posteridade um dos mais célebres documentos racistas, uma suma teológica à luta racial contemporânea a qual Jud Süß podia se referir para delegar a uma fonte idônea a virulência de sua encenação. STEIGMANN-GALL, Richard. Op. cit., 33, 66, 77, 79-80, 84, 103-4.
} 
pelas suas afinidades cristãs e pela oposição a um único inimigo. Oferecendo a todos os segmentos da cristandade o mesmo oponente, o judeu, o nacionalsocialismo tencionava colocar fim à longa e sanguinolenta tradição sectária ${ }^{49}$.

Daí que, na esteira do debate antissemita, alguns bispos luteranos vislumbrassem no nazismo o tardio cumprimento do ideal social protestante, $\mathrm{o}$ gesto derradeiro da Reforma. Foram, não obstante, vozes isoladas. Os doutrinadores nacionalistas surpreenderam-se que a totalização teológica permanecesse alheia aos mais importantes setores do clero protestante. A corrente liberal, o Kulturprotestantismus, já antes de 1918, rejeitava o extremismo dos movimentos pré-fascistas ${ }^{50}$. No campo oposto, a percepção não diferia. Dado que a aproximação nazista desconsiderava a dogmática teológica, desde 1934, setores da Bekennende Kirche, a Igreja Confessional, interpelavam os apologistas do regime contra o assalto indiscriminado às suas doutrinas. Seu sínodo prontamente reconheceu que a arianização de suas igrejas pela adoção do Führerprinzip, o princípio de obediência incondicional a Hitler, feria o primeiro mandamento e denunciava a secreta intenção do regime de descristianizar o povo alemão ${ }^{51}$.

${ }^{49}$ STEIGMANN-GALL, Richard. Op. cit., 45-6, 50, 52, 54, 58, 73-4.

50 Os protestantes liberais respondiam ao problema da heresia dos judeus apelando para a amplificação de seus direitos sociais, de sua liberdade política e de sua emancipação. Pretendiam encerrar, no plano terreno, o processo escatológico de salvação de todas as almas. Esperavam que, pela provisão da liberdade política, os judeus se engajariam voluntariamente à fé luterana. STEIGMANN-GALL, Richard. Op. cit., 37-8, 48, 76, 78.

${ }^{51}$ Fundada em 1932 por uma corrente de teólogos luteranos, a Igreja Confessional resultou de intensos debates teológicos entre as décadas de 1920 e 1930. Buscava responder aos reajustes do espaço legal do protestantismo impostos pelos artigos 135-41 da Constituição de Weimar que determinaram a separação entre Estado e Igreja, relegando os protestantes à mesma situação política dos católicos. Defendia o retorno às tradições, o respeito à disciplina e à autoridade e a reabilitação da família. Disputava com os movimentos nacionalistas, incluindo o NSDAP, os mesmos segmentos da população - a juventude, os operários, os profissionais liberais e os intelectuais - numa plataforma de rejeição à modernidade, ao materialismo, ao socialismo e ao comunismo. Esse movimento ofereceu significativa resistência aos fascistas no ponto mais sensível da ditadura hitlerista - o destino dos judeus não convertidos. Opôs-se resolutamente ao antissemitismo racial pelo paradoxal vislumbre de um denominador teológico comum ao judeu e ao nazista: a identidade étnico-racial. Entendera que ambos os segmentos contrariavam a visão humanista cristã porque sacralizavam o meio natural, a herança da carne, do sangue e da terra. Nazistas e judeus negavam a revelação messiânica de Jesus, perseguindo a miragem de um reino centrado no homem, não em Deus. Na afirmação nacionalista do Terceiro Reich repousavam os mesmos argumentos étnico-raciais que sustentavam as alegações sionistas. Desse modo, tanto o Reich quanto o Sião se exprimiam no vocabulário da autodeterminação para recusarem a salvação pela fé. Aos olhos do luteranismo tradicional, eram os dois, portanto, abomináveis: TAL, Ulrich. 

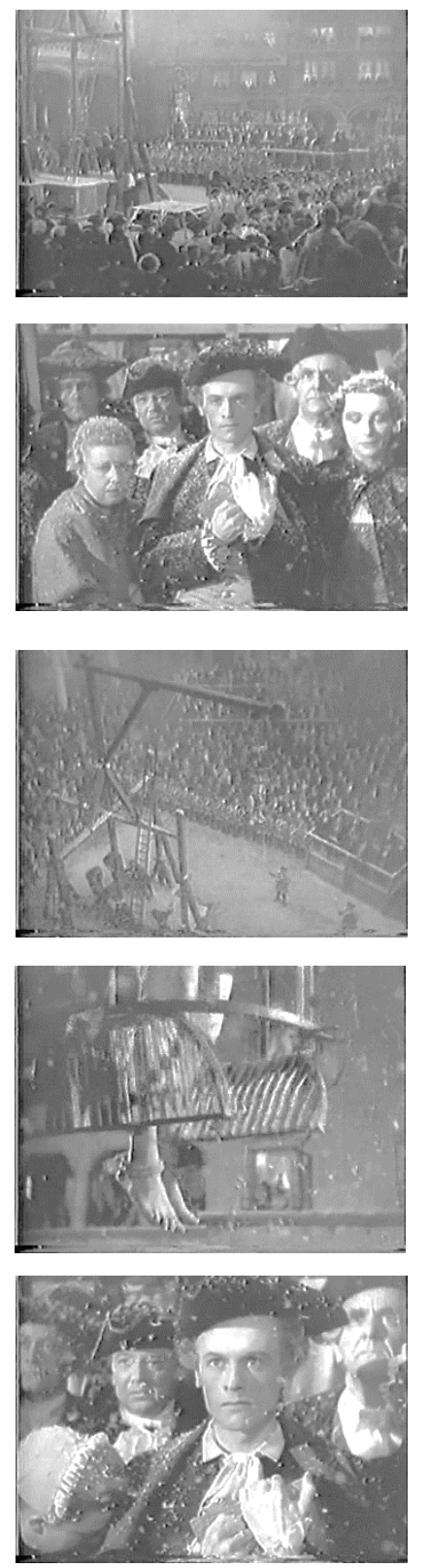

Figs. 1.4, 1.5, 1.6, 1.7 e 1.8 : Malte Jägger

Buscando concatenar esse conflituoso imaginário político-religioso em uma figuração cinematográfica, Jud Süß evolvia da narração construída em torno do judeu à sua destituição como personagem privilegiado. No desfecho do filme, a sequência da execução de Süß, o ponto de vista da ação sutilmente deslocava de Oppenheimer a um personagem até então marginal na trama, o jovem Faber. No seu virulento antissemitismo, no ardor revolucionário e no respeito à autoridade Faber carregava os marcadores do novo homem fascista. Seu comportamento passional e impulsivo evocava a conduta da juventude hitlerista. Um racista prodigiosamente hábil, era capaz de farejar à distância qualquer judeu se fingindo de gentio. Numa época em que o adjetivo fanatisch perdera seu sentido primitivo (a qualidade de cegueira do juízo sob efeito da vertigem religiosa) ${ }^{52}$, Faber expressava o fanatismo nazista na sua forma mais exaltada - e, posto que inexistiam fanatismos plácidos, suas ações sempre descreviam ânimos hostis, emoções beligerantes e estados psíquicos violentos. A aparência física do ator Malte Jäger (o rosto adunco, os cabelos louros e os olhos claros guardavam uma agradável semelhança com o jovem Schiller), no mais, acentuavam o estreito parentesco do personagem com o contemporâneo militante nazista 53 .

Porque fora ignominiosamente torturado por Süß, seu corpo trazia, na cena final, o signo da mutilação. A mão esquerda deformada sob ataduras denunciava,

\footnotetext{
Religion, Politics and Ideology in the Third Reich: Selected Essays. Londres e Nova York: Routledge, 2004, 98, 179-80, 191-3, 194, 197-9.

52 KLEMPERER, Victor. LTI: a linguagem do Terceiro Reich. Tradução: Miriam Bettina Paulina Oelsner. Rio de Janeiro: Contraponto, 2009, 111-3, 115-6, 119.

53 SINGER, Claude. Op. cit., 174.
} 
num índice subliminar, a profundidade de sua castração. Registrava no seu corpo a amputação irreversível cujo maior denominador era o desaparecimento de sua noiva, a desventurada Dorothea. A sequência propriamente dita dividia-se em duas perspectivas. Simulando o omnisciente olho de Deus, tomadas panorâmicas enquadravam o judeu condenado diante da multidão aguardando sua execução. Alternavam-se com planos médios e close-ups de Faber, rodeado pelos cidadãos de Württemberg. Na primeira seleção de enquadramento, Oppenheimer, clamando pela sua vida, tornava-se o desprezível objeto do espetáculo. A posição privilegiada de Faber na montagem indicava que a encenação era dirigida em especial a ele. Imediatamente após o corpo de Süß despencar do patíbulo, a câmera se voltava para o rosto impassível do ariano. Flocos de neve dissipavam os últimos vestígios de contaminação. Na semântica do filme narrativo, tudo indicava que a harmonia original fora enfim restaurada ${ }^{54}$.

O enforcamento conduzia-se com serena solenidade. Após os terríveis atos do criminoso, na circunspecção da cerimônia de sua morte, divisava-se uma racionalização da atitude antissemita. Essa compostura, por extensão, estendiase da cena aos observadores. Era também solicitada dos espectadores arianos assistindo ao rito final (na diégese e na plateia) diante das pendentes medidas de expatriação dos judeus. Frente ao cadáver balançando, o conselheiro Sturm restaurava a forma da lei no topos do biopoder. Restituía a Württemberg a dimensão de espaço imaginariamente fechado e singularizado, circunscrito em seu território onde as políticas raciais podiam voltar a incidir normalmente. $\mathrm{O}$ édito que Sturm anunciava restabelecia a confiança num domínio espacial seguro, disciplinado e homogêneo, livre das multiplicidades, nivelado pela lei um habitat para a raça exemplarmente higienizado, em tudo conforme à biopolítica foucaultiana ${ }^{55}$.

Os judeus não mais subiam à cena, uma ausência constelada de

\footnotetext{
54 SCHULTE-SASSE, Linda. Op. cit., 87-9.

${ }^{55}$ FOUCAULT, Michel. Em defesa da sociedade: curso no Collège de France (1975-1976). Tradução: Maria Ermantina Galvão. São Paulo: Editora WMF, Martins Fontes, 2010, 204-8, 211, 214-6 e FOUCAULT, Michel. Segurança, território, população. Tradução: Eduardo Brando. São Paulo: Martins Fontes, 2008, 3-8, 11, 16-7, 20, 23-4, 26-7.
} 
significados, porque, na arte e na realidade, todos os novos ordenamentos de desnacionalização faziam deles o termo final da disputa. Nas convenções do biopic, constituíam, até então, uma presença conspícua, pois, ao contrário dos extras que recheavam as cenas de multidão em Stuttgart, não pertenciam ao meio cinematográfico, mas ao ambiente efetivo que o filme pretendia exorcizar. As duas tomadas retratando o tropel semita - a sinistra cena da ocupação de Stuttgart e a sequência do convulsivo rito na sinagoga - foram rodadas com judeus provenientes de Praga. Deliberadamente selecionados pelos seus traços orientais, Veit Harlan orientou os figurantes a representarem as cenas com modos frementes e abandonados, acentuando a impressão de selvageria. Jud Süß abrira com eles o círculo do passado, remetendo simbolicamente a eterna sina do povo amaldiçoado à atualidade das deportações ${ }^{56}$. Tornava a-histórica a política que condenava os hebreus a cumprirem seu destino de desterro. Num filme arquitetado para despertar a paixão antissemita, os lances repletos de genuínos judeus não apenas revestiam a ficção com o lustro do realismo, mas também atualizavam o objeto para fora das bordas da narrativa. A audiência percebia a presença das figuras como pessoas reais, o que reforçava extradiegeticamente a verossimilhança da mensagem doutrinária. O judeu maldito era, assim, alçado diacronicamente além da ficção, e sincronicamente além do tempo ${ }^{57}$.

Fazendo todos os elementos contraditórios desaparecerem - Dorothea, Karl Alexander, Oppenheimer, os aristocratas e, enfim, a turba semita - restava na memória do público a redolente evocação do desafortunado Faber, o triste protótipo do herói fascista, petrificado pelo sofrimento, purgado pela experiência de seus excessos, destituído de seu idealismo, transfixado pelo ódio, emasculado por um judeu pervertido, mas finalmente remido do dolo pela vitória do racismo. Traumatizado por experiências terríveis, ele sobrevivera conjurado à sua comunidade. Porque, ao final de tudo, o judeu morreu em seu lugar, levando consigo todas as culpas, Faber encerrava sua trajetória castrado, mas limpo da mácula, redimido pela graça de sua raça. Simplesmente justificado.

\footnotetext{
${ }^{56}$ WELCH, David. Op. cit., 240-1.

57 SINGER, Claude. Op. cit., 181 e TEGEL, Susan. Op. cit., 137.
} 


\section{Melodrama romântico}

A parcela mais expressiva (ainda que menos impressiva) da filmografia de Veit Harlan não incidia no drama histórico, mas no melodrama romântico. Na maior parte de sua carreira de diretor cinematográfico, Harlan devotou-se ao espetáculo da ruína de heroínas desvirtuadas pela luxúria de homens vãos. $\mathrm{O}$ pathos, mais do que qualquer coisa, era sua filosofia artística. Os filmes que dirigiu, em geral estrelados por sua esposa, Kristina Söderbaum, serviam apropriadamente à doutrina fascista porque imergiam nas formas fixas da convenção melodramática para delas extraírem uma resposta pronta. À luta do Bem contra o Mal, à corrupção da inocência, aos mascaramentos do desejo e à moral ofendida devolvia quase invariavelmente a mesma representação conciliatória: o cadáver autoimolado da mulher vilipendiada. $\mathrm{O}$ seu universo ficcional produzia o gozo da vingança nem sempre contra o ofensor, mas consistentemente contra a parte ofendida ${ }^{58}$.

Dessa peculiaridade criativa, sua obra mais infame, Jud Süß, incidiria numa representação quintessencial do cinema da era nazista: o miraculoso defunto produzido no determinante evento da repactuação social da comunidade. Com a dramatização da cerimônia da morte num registro estridentemente melodramático, a produção provia uma chave para interpretação do fato histórico numa invariante construção mórbida à qual o diretor se devotou em quase toda sua filmografia. E mediante essa convenção do melodrama, os ajustes ideológicos conveniados nas tramas de suas realizações tornavam-se válidos porque eram referendados também num pacto espectatorial. Promanavam as ideias fascistas numa categoria de gênero consagrada e esteticamente decodificável à sua audiência.

Jud Süß ficcionalizava agressivamente eventos históricos não somente porque os deformava, mas sobretudo, por incidir sobre eles essa apelativa solicitação melodramática. A produção reescreveu um mélange de fatos reais e ficção numa modalidade narrativa atraente aos espectadores, fornecendo-lhes modelos com os quais eles podiam prontamente se identificar. Porque retinha os

\footnotetext{
${ }^{58}$ RENTSCHLER, Eric. Op. cit., 168.
} 
traços fundamentais da forma melodramática - a qualidade de um teatro popular, de uma mise en scène dos dramas da nação, de uma moralidade revolucionária - o filme investia num modo de excesso para a expressão extrema e desinibida das emoções ${ }^{59}$. Seguindo as prescrições do gênero, oferecia a superfície inflada de sentimentos polarizados na latitude do Bem e do Mal para validar os afetos morais, realçando sua importância e incidência na existência ordinária dos homens ${ }^{60}$.

Na sua vertente alemã, o melodrama se preocupava em urdir um protocolo narrativo para homologação de valores liberais - a liberdade, a virtude e a decência. E posto que coincidiu com uma época de generalizada falência das estruturas do poder absolutista, singularizaria dois sistemas éticos. De um lado, modelava um imaginário da ordem burguesa, caracterizado pela valoração da fidelidade, da comunidade, da família, da honestidade, da verdade e da linguagem simples. De outro, contrapunha uma cena aristocrática centrada nos temas da inveja, da intriga, da especulação política, da ambição, do poder, da gratificação sexual, da afetação e da linguagem empolada. Porquanto na Alemanha esse gênero rejeitasse a luta de classes, a ética burguesa era então projetada como natural e universal, portanto aplicável a todos os estratos sociais ${ }^{61}$. Seguia, nesse domínio, as linhas mestras da moralidade que a burguesia idealizou para si. Contemplava, numa forma estética, aquela acomodação ideológica que transformara uma racionalização específica da família e do sexo na crucial trincheira disciplinadora dos corpos para fazer deles ferramentas politicamente dóceis, socialmente úteis e economicamente produtivas ${ }^{62}$. Consequentemente, ao invés de divisar os conflitos na arena política, o gênero deslocava-os para o território da família patriarcal. Em torno dessa instituição nuclear da burguesia organizava-se o campo da disputa dramática que, na sua

\footnotetext{
59 SCHULTE-SASSE, Linda. Op. cit., 48 e THOMASSEAU, Jean-Marie. O melodrama. Tradução: Cláudia Braga e Jacqueline Penjon. São Paulo: Perspectiva, 2012, 10, 15, 17.

60 BROOKS, Peter. The Melodramatic Imagination: Balzac, Henry James, Melodrama, and the Mode of Excess. New Haven e Londres: Yale University Press, 1995, 47-9.

${ }^{61}$ SCHULTE-SASSE, Linda. Op. cit., 52-3.

62 FOUCAULT, Michel. Histoire de la sexualité 1: la volonté de savoir. Paris: Gallimard, 2003, 140, $142-5,152-9$.
} 
forma típica, principiava pela investida de um aristocrata depravado contra a pureza de uma recatada virgem burguesa ${ }^{63}$.

Capitalizando sobre os referentes actanciais do melodrama (os vilões da nobreza, a virgem em perigo, o gentil herói, os patronos da justiça), Jud Süß investia energicamente na defasagem entre os labores emancipatórios da burguesia e o despotismo aristocrático. Contrastava a postura anticentralista e antiabsolutista da Dieta à racionalidade da política palaciana. No sistema binário do melodrama, o filme introduzia, por essa via, um terceiro e inédito elemento, o forasteiro judeu. Para manter intacto o princípio bipolar do gênero melodramático, o enredo deslocava, assim, o foco do conflito do embate entre burgueses e nobres para a luta dos arianos contra os semitas ${ }^{64}$.

A transição ficcional se processava sem solavancos porque entre os nobres e os judeus fora sedimentada uma conexão histórica que remontava aos primórdios da afirmação nacionalista e da gênese das unidades estatocêntricas. O embate entre judeus e burgueses constitui, então, um peculiar capítulo da história do imperialismo europeu. Um cortesão elegante e libertino, um livre pensador e um sagaz consultor financeiro, Süß Oppenheimer era um subproduto da nobreza a qual, entre os séculos XVII e XVIII, ancilou às suas estruturas de poder aquela excêntrica categoria de judeus abastados. Pertencia a uma classe social única, destinada a evaporar com o fortalecimento poder estatal e sua subsequente cooptação pelos arrivistas dos extratos médios da sociedade ${ }^{65}$.

\footnotetext{
${ }^{63}$ SCHULTE-SASSE, Linda. Op. cit., 53.

${ }^{64}$ SCHULTE-SASSE, Linda. Op. cit, 55, 60-2.

${ }^{65} \mathrm{Em}$ seu apogeu, os cortesãos judeus trabalhavam individualmente nas casas reais em que seus serviços entravam em demanda. Embora cada um deles possuísse conexões e créditos em vários países europeus, jamais vieram a constituir uma entidade financeira supranacional. Precisamente porque permaneceram inassimiláveis na fusão nacionalista podiam transitar com mais prontidão de um território a outro, dinamizando as negociações internacionais. Sua importância na manutenção da balança de poder europeia derivava do fato de não pertencerem a nenhuma nação, exceto a sua. Por isso, funcionavam como elementos transnacionais nos convênios políticos e no tráfico de capitais, de influência e de informações. Declinaram em número e importância com as revoluções populares que elevaram a burguesia e os emergentes Estados nacionais para a linha de frente das lutas imperialistas. Na nova conjuntura, poucos deles retiveram seu prestigio político e econômico, conservando consigo capital suficiente para o investir em ativos estatais. Um contrato tácito, por conseguinte, aproximava judeus e nobres. Ambos comungavam da oposição aos novos valores da classe burguesa. Eram ligados por vínculos familiares multinacionais. Pertenciam a uma comunidade intereuropeia para a qual a lealdade às causas nacionalistas locais era muito menos atraente do que a preservação dos laços consanguíneos e
} 
No alinhamento dos judeus à aristocracia, Jud Süß levava ambos a protagonizarem enredos de intrigas palacianas e figurações de indolência e parasitismo. Sobreposto ao melodrama, o pendor antissemita implicava o nobre e o hebreu nos mesmos predicados. Os dois eram inescrupulosos, desenraizados, ávidos de poder, afetados e promíscuos. Por trás dos modos elegantes, tanto o Duque quanto Süß não passavam de vigaristas rapaces e violadores de mulheres. Judeus, contudo, mostravam-se mais polimórficos, um marcador de sua negatividade racial: não apenas pródigos como Süß, mas também primitivos, sujos, esfarrapados e feios. A multidão informe de semitas oferecia o obverso opaco da cintilante aristocracia de Stuttgart ${ }^{66}$.

Na chave melodramática, os recursos de ação de Süß Oppenheimer abrangiam, consequentemente, toda gama de ferramentas que o gênero protocolava aos inimigos (aristocratas) da virtude (burguesa): o sexo, o dinheiro e a intriga ${ }^{67}$. Essa tríade, a tradição do melodrama o corrobora, não se circunscrevia à filiação étnica de Oppenheimer. Ao contrário, a questão racial era indexada a ela como um fator intrínseco de vilania. Uma vez ali, remanescia como um excedente que imantava com uma aura espectral todos seus nefandos trabalhos. Do que se conclui que, em si mesma, a doutrina racial não produzia nenhuma narrativa própria. Necessitava servir-se dos dispositivos da ficção melodramática para se fazer visível. Quando modelado no padrão do melodrama, Oppenheimer era um vilão - como tal, podia ser marcado como judeu.

Numa sequência de Jud Süß, um moleiro se queixava ao secretário Levy dos pedágios impostos por Oppenheimer para o transporte de mercadorias. Num incompreensível volteio retórico, Levy lhe explicava que deveria se sentir grato

culturais. Depois da destruição da aristocracia, os judeus resistiriam sozinhos como o único remanescente estrangeiro numa Europa nacionalizada e recortada por Estados. ARENDT, Hannah. The Origins of Totalitarism. Nova York: Harcourt, 1997, 15-21, 31, 40.

66 TEGEL, Susan. Op. cit., 142.

${ }^{67}$ SINGER, Claude. Op. cit., 124, 126. 
pelos tributos, pois eles aumentavam o preço de suas mercadorias, elevando as suas taxas de lucro (um argumento injustificável do ponto de vista econômico). Nesse breve colóquio, era explicado como a inflação, companheira fiel dos judeus, chegara a Stuttgart. Jud Süß formulava, assim, uma crítica ao capitalismo e à imposição da modernização econômica da sociedade. Revelava o horror ao sistema financeiro contemporâneo, à inflação, às flutuações de oferta, ao peso do Estado na economia e a nostalgia de uma existência comunal baseada nas relações imediatas de troca e no comércio de bens fungíveis. Oferecia, no nível da metáfora, a dramatização do nascimento do capitalismo à sombra do regime absolutista e denunciava o hebreu como o primeiro e o maior beneficiário da crescente abstração do dinheiro ${ }^{68}$.

O capitalismo oferecia, nessa dimensão, uma armadura simbólica para o antissemitismo. As novas dotações de valor, a intangibilidade, a mobilidade e a universalidade da mercadoria assentavam-se plasticamente à malha discursiva antissemita. No duplo caráter da mercadoria, a tensão entre os valores de troca e de uso, a dialética entre o dinheiro (a forma manifesta do valor) e a commodity disputavam dois domínios: o trabalho concreto e a abstração da moeda. A retórica racial podia ali identificar um modo de produção ariano, essencialmente feudal, artesanal, reputado como natural e orgânico, de um modo judaico, moderno e predatório ${ }^{69}$.

Para comutar os preconceitos étnicos em uma semântica cinematográfica, nas suas representações, Jud Süß imputava à ambição materialista dos hebreus a corrupção do bem-estar social ariano. Seu dinheiro ilícito naufragava a economia nas tramas impenetráeis dos sistemas financeiros. Como tal, corroía as relações naturais de troca. Na metafórica tragédia encenada em Württemberg, a administração de Oppenheimer instaurava o sobrepreço, deflagrava a inflação, ampliava a brecha entre os ricos e os pobres, produzia a carência e oprimia a todos pela perversidade dos impostos ${ }^{70}$.

Jud Süß dramatizava o antagonismo entre os valores material e abstrato dos

\footnotetext{
68 SCHULTE-SASSE, Linda. Op. cit., 67-8.

${ }^{69}$ SCHULTE-SASSE, Linda. Op. cit., 69-71.

70 SINGER, Claude. Op. cit., 131-2.
} 
bens econômicos sobredeterminando-os racialmente. Os objetos, nas mãos dos judeus, perdiam suas virtudes concretas e, reduzidos ao fetiche, circulavam na sociedade mercantilizando todas as relações, em especial aquelas da ordem sexual. As coruscantes joias de Süß presentificavam os prazeres eróticos e os delírios de grandeza do Duque. Seu poder financeiro literalmente abstraía as pessoas, destituindo-as de sua subjetividade. As mulheres eram, em particular, medidas pelo seu valor de compra, oferecidas como matéria prima do prazer e como ornamento de massa ${ }^{71}$. Pelo dinheiro, Oppenheimer franqueava o sexo: no seu modus operandi, ambas as coisas eram intercambiáveis. Onipresente, o ouro judeu mediava e gratificava os desejos do Duque com bailarinas, festas, joias e exércitos. Como um feiticeiro maligno em posse desse sortilégio polivalente, Süß podia tornar material tudo o que a imaginação do governante solicitasse ${ }^{72}$.

Drasticamente definidas ou como santas ou como vadias, as figuras femininas ao redor de Oppenheimer expressavam ressentimentos culturais tão extremos quanto aqueles endereçados aos judeus ${ }^{73}$. Conjurada na trajetória ficcional como objeto nodal da trama, a representação das mulheres atendia ao propósito conformar o problema da ordem política numa política do corpo. Sobre elas e sua conduta pendia uma disputa ideológica mais ampla, aquela que definia o próprio escopo da afirmação da burguesia como classe social autônoma ${ }^{74}$.

Em Jud Süß, não apenas uma convenção estética demarcava no corpo de uma virgem o território metafórico da luta social e da integridade comunitária. O arranjo simbólico do filme contrastava a fêmea aristocrática à donzela burguesa. Pretendia comprovar, por esse meio, a precedência moral da classe adventícia sobre a nobreza corrompida. Em primeiro lugar, porque na sua condição de natureza vencida e domesticada, a mulher fora historicamente condenada pela ideologia burguesa a encarnar e cultivar o belo. Por trás do louvor masculino à beleza, ocultava-se desde o princípio um obsceno desprezo

\footnotetext{
${ }^{71}$ SCHULTE-SASSE, Linda. Op. cit., 72-3.

72 SINGER, Claude. Op. cit., 130-1.

73 TEGEL, Susan. Op. cit., 143-4.

74 SCHULTE-SASSE, Linda. Op. cit., 56-7.
} 
do sexo "potente" ao sexo "fragilizado"75. Também, porque, transbordando desejo sexual e castigado por patologias intrínsecas, o corpo feminino, observou Foucault, "estava colocado em comunicação orgânica com o corpo social (do qual ele deve assegurar a fecundidade regrada), o espaço familiar (do qual ele deve ser um elemento substancial e funcional) e a vida das crianças (que ele produz e que deve garantir por uma responsabilidade biológico-moral que deve durar por toda educação)"76. E, por fim, ao nível psíquico: sobre o corpo da mulher a fantasia masculina engendrou um palco de acontecimentos extraordinários. Seu útero engoliu o temível pênis do pai e dele brotaram irmãos hostis. O peito materno constituiu, na infância, um objeto ambíguo de desejo e terror. Ligada à mãe por um anseio precocemente sádico em lhe deglutir não apenas o leite, mas também a mama, a criança anteviu, por projeção, uma retaliação similarmente violenta. Imaginou o organismo da mãe se rebelando para lhe impor um castigo à altura da sua ofensa, devorando-o ou o castrando. O desejo infantil de saquear sua anatomia se deteve pelo pavor à represália. Nesse primitivo impulso sádico, Melanie Klein vislumbrou a precoce origem da paranoia. Do peito, o primeiro protótipo objetal, a criança formulou, então, dois componentes: o bom objeto que lhe sacia as necessidades e o mau objeto que a intoxica, ameaça-a e, mais tarde, rejeita-a. Daí em diante, a diferenciação objetal permanecerá indefinidamente comprometida pela angústia de que os objetos bons ou escondem os maus ou foram por eles corrompidos e pelo temor de que, no momento da posse de um bom objeto, ele se volte vingativamente para canibalizar o ego ${ }^{77}$.

Sobredeterminado pela ótica masculina, Jud Süß glosava essa mesma codificação no âmbito da defasagem entre os gêneros sexuais própria ao melodrama. Cindia o feminino nesse objeto parcial, provendo duas modalidades de mulher, a boa e a má, essa a aristocrata debochada, aquela a pudica

\footnotetext{
75 ADORNO, Theodor W., HORKHEIMER, Max. O homem e o animal in ADORNO, Theodor W., HORKHEIMER, Max. Dialética do esclarecimento: fragmentos filosóficos. Tradução: Guido Antonio de Almeida. Rio de Janeiro. Zahar Editora, 1985, 208-9.

${ }^{76}$ FOUCAULT, Michel. Op. cit. 137.

77 KLEIN Melanie. Primeiras fases do complexo de Édipo e Uma contribuição à psicologia dos estados maníaco-depressivos in KLEIN, Melanie. Contribuições à Psicanálise. Tradução: Miguel Maillet. São Paulo: Editora Mestre Jou, 1970, 256-63, 355-9.
} 
burguesa $^{78}$. Enquanto maus objetos, pela sua crueldade lúbrica e sua inata carnalidade, as damas da nobreza se alinhavam a Süß. Igualavam-se a ele em baixeza e descaramento ${ }^{79}$. Contrariamente, a honestidade da virgem burguesa precipitava a ação rumo ao clímax. Atendendo às prescrições do gênero, em Jud Süß, a branda filha do edil Sturm, Dorothea, não existia para si. Tratada sem rodeios como propriedade do patriarca, a narrativa dispunha dela tão logo o pai fora privado de sua posse. Destituída de sua virgindade, seu "frágil tesouro", não se prestava mais a ser assinalada no campo dos bons objetos. Igualmente, pelo seu alinhamento originário à virtude burguesa, não podia ser comutada num objeto mau. A fantasia ficcional resolvia o impasse objetal suicidando-a. Destruindo-a como objeto, transformava-a no não-objeto, na Coisa sadeana, para o que toda idealização se tornava possível ${ }^{80}$.

Um autômato subserviente ao pai e ao seu sucedâneo, o noivo, uma projeção do filtro masculino mecanicamente movida por uma vontade alheia a si mesma, Dorothea era uma extensão dos homens que detinham sua posse. Daí que, na representação da violência sexual, o filme formulava a perturbadora fantasia de uma desonra que incidia não apenas sobre ela, mas também em toda comunidade masculina. Essa dupla violação subjazia na articulação de duas sequências simultâneas, encadeadas na montagem: o ataque à donzela e a tortura de seu noivo. Recepcionada usualmente em apenas um de seus componentes (a impactante conjuntura do estupro), a totalidade da cena envolvia, pois, dois instantes concomitantes de insulto ao corpo ariano. Enquanto a donzela se perdia nos aposentos de Oppenheimer, na câmara contígua, Faber era também

\footnotetext{
78 SCHULTE-SASSE, Linda. Op. cit., 55, 57.

${ }^{79}$ Num célebre episódio, durante um passeio de carruagem, Oppenheimer e sua amante Luziana desfilavam adiante de uma casa literalmente partida ao meio para abrir caminho às estradas do ministro. "Que linda casa de boneca", deleitava-se a aristocrata: "você é tão doce". O inegável gozo erótico diante da destruição impugnava a ela o traço de descomedimento sádico pelo qual o melodrama burguês discriminava a corrupção de seu meio social O caminho desse doce gozo sádico passava, ademais, pelo abuso do verbo num jogo de trocas simbólicas da palavra à imagem. Entre o nome Süß e o adjetivo süss, "doce", havia uma relação de homofonia que, aposta à impressionante visão da casa rachada, encetava uma metáfora verdadeiramente demolidora da perversão sexual materialmente realizada num ato. SCHULTE-SASSE, Linda. Op. cit., 73-4 e TEGEL, Susan. Op. cit., 144.

80 SCHULTE-SASSE, Linda. Op. cit., 57.
} 
brutalizado numa sessão de suplício. A montagem comportava, assim, uma

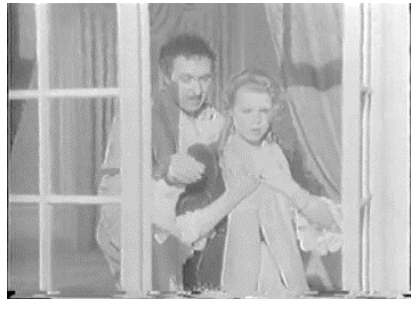
dupla representação da afronta física: a contaminação da mulher e a castração simbólica do homem ${ }^{81}$.

Nas suas investigações junto a pacientes neuróticos, Freud se surpreendeu com a incidência de

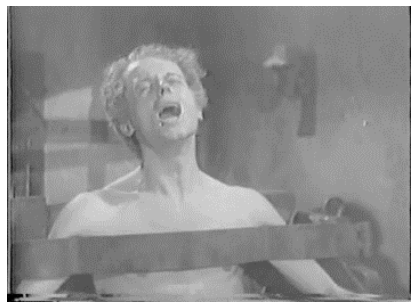
uma fantasia repetidamente evocada. Inventariou suas variedades numa cena genérica intitulada Uma criança é espancada. Essa elaboração, observou, produzia junto ao seu enunciador uma intensa satisfação autoerótica,
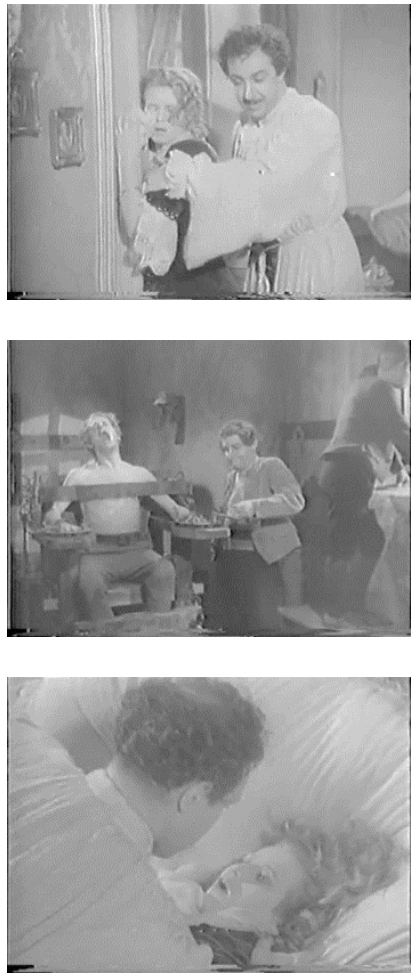

Figs. 1.9, 1.10, 1.11, 1.12 e 1.13: Ferdinand Marian, Kristina Söderbaum e Malte Jägeer ainda que carregada de sentimentos culposos, pois, provinha de uma inclinação sádica que se voltou contra o próprio sujeito fazendo do ego o lócus da fixação masoquista ${ }^{82}$. Uma fantasia que, mais tarde, Lacan decupou em seus três protagonistas fundamentais: o agressor (o avatar do pai), a vítima (um rival do sujeito nos afetos paternos) e a testemunha (o próprio sujeito), essa, em geral, situada no anonimato de uma plateia de observadores. A cena incidia, disso, na dessubjetivação do espectador que se reduziu a uma parte inerme de si mesmo, o olho 83 .

A imagem concretizada do flagelo de um homem para o prazer contemplativo dos espectadores em Jud Süß incidia, daí, num circuito psíquico defensivo conforme à mentalidade nacional-socialista. A cena $U m$

81 SCHULTE-SASSE, Linda. Op. cit., 82-4.

82 Essa fantasia originava-se em uma época precoce, ao redor dos cinco ou seis anos de idade e, daí, evolvia numa pluralidade de colorações, enriquecida pelas experiências disciplinadoras posteriores. Erotizava personagens autoritários cujo primeiro modelo remontava à figura paterna. Colocando a satisfação instintual no horizonte do sofrimento, o devaneio do espancamento tomava a frente dos demais conteúdos e passava a ocupar o primeiro plano das atividades libidinais. Resistia como um derrelito da psique infantil na idade adulta pela qual o sujeito se acomodava à atitude passiva diante da violência. FREUD, Sigmund. Uma criança é espancada, in Obras psicológicas completas de Sigmund Freud Volume XVII. Tradução: José Luiz Meurer. Rio de Janeiro: Imago, 1996, 193-5, 198-210.

83 LACAN, Jacques. O Seminário livro 4: a relação de objeto. Tradução: Dulce Duque Estrada. Rio de Janeiro: Zahar Editora, 1995, 119-21. 
ariano é espancado acomodava a situação do estupro da mulher a um estágio de paralisia psicológica masculina. Estacionava a representação num convite ao enrijecimento o qual, por sua vez, expandia-se nos padrões mais gerais do ideal de masculinidade cultivado pelo fascismo. $\mathrm{O}$ arrimo global da fantasia sobre o qual toda a publicidade nazista pendia era precisamente o gozo da saciedade interrompida, postergada e, por fim, recalcada. A aproximação disciplinada do desejo indicava um esforço de resistência, pois o prazer gratificado trazia consigo a qualidade da dissolução, um estado particularmente angustiante para a rigidez fascista. Um dos grandes triunfos da propaganda foi, por isso, o estabelecimento de um vínculo entre a proximidade do judeu e o contágio pela descarga sensorial imediata. Não apenas os preconceitos anticapitalistas e antibolcheviques o equacionavam à categoria dos exploradores, mas, sobretudo, as superstições em torno de sua poderosa lascívia. Na sua luxúria se organizavam preliminarmente os demais argumentos: ela tornava o liberalismo e o comunismo "imundos" e não o contrário 84 .

O judeu provia, por isso, uma imensa face para o apelo da incontinência que desafiava os esforços de enrijecimento do caráter fascista. Sintomaticamente, os anseios se manifestavam pela repulsa às substâncias sexuais emanadas do hebreu, à matéria da sua excitação e as seivas contaminadas do seu ato sexual. Mediante isso, os ideólogos podiam categorizar aquele outrossim vago sentimento de aterrorizante abjeção que aos hebreus votavam ${ }^{85}$. “Durante o coito,

84 THEWELEIT, Klaus. Male Fantasies Volume 2: Male Bodies: Psychoanalyzing the White Terror. Tradução: Stephen Conway, Erica Carter, Chris Turner. Minneapolis: University of Minnesota Press, 2010, 8-10, 12-3.

${ }^{85}$ Sob uma estética de exagero e sem nunca produzir qualquer discurso eficiente sobre si mesmo, nos filmes antissemitas da década de 1940 o judeu se assomava como uma presença plástica, polimórfica e esquiva. Modelava invariavelmente o referente negativo, indexado a uma difusa cadeia de significantes: o rato errante deambulando sem horizonte, o primitivo infiel expatriado, o usurário plutocrata, o usurpador bolchevique, o pervertido sexual, o poluidor das raças, o vetor da peste e da sarna, o verme hematófago (ainda que sempre consumido pela anemia), o imundo, o fedido, o infectante, o Untermensch (o sub-humano), a nua vida degenerada que não merecia ser vivida. Jud passava então a conotar uma genérica e toda-inclusiva qualidade de abjeção, a qual, segundo Julia Kristeva, era a lacuna vazia da significação, um não-objeto, um abejto. O abjeto antecede o próprio objeto na determinação egóica dos sujeitos: surgiu como a primeira elisão marcando no eu o que lhe era externo e contaminante. Localizou-se na fronteira do inassimilável e do indizível. Uma parcela amputada do discurso, o abjeto transborda sua infecção para além de si mesmo. Coloca, assim, o ego em permanente risco de dissolução. "Não é então a ausência de propriedades ou de saúde que produz o abjeto, mas aquilo que perturba uma identidade, um 
o sêmen masculino é total ou parcialmente absorvido no forramento do útero feminino, de onde entra na corrente sanguínea", explicava o professor e editor do jornal Der Stürmer, Julius Streicher num discurso de 1926. “Um simples ato de intercurso entre um judeu e uma mulher ariana é suficiente para envenenar seu sangue para sempre" 86 .

Os padrões hiperbólicos dessa linha de raciocínio escondiam mal a finalidade de realizar retoricamente os desejos que proscreviam. Nas escandalosas obscenidades, nos excessos sensuais, nas atrozes histórias que a demagogia fascista urdia ao redor de seus antagonistas, uma transparente racionalização canalizava o gozo para o conter pelo verbo. A virulência dos discursos abria as portas do proibido ${ }^{87}$. Imantava com o determinante componente do ódio aquilo que, a princípio, era uma intensa curiosidade sexual, agora deformada pela paranoia e pelo sadismo ${ }^{88}$. Assim, o nazista colocava o judeu a serviço do seu prazer.

Süß contrapunha à rigidez ariana do patriarca Sturm e ao temperamento fanático de Faber uma sensualidade negativa, contagiosa, estritamente carnal, não apenas cínica, mas infectante porque desregrada. Num filme desenhado para cultivar o ódio, o tema romântico de Faber e Dorothea, a canção folclórica do século XIX All' mein' Gedanken, die ich hab', die sind bei Dir (“Todos pensamentos que tenho são por você"), observou Eric Rentschler, soava não como um hino ao

\footnotetext{
sistema, uma ordem. O que não respeita os limites, os lugares, as regras. O intermediário, o ambíguo, o misto". KRISTEVA, Julia, Pouvoirs de l'Horreur: Essai sur l'abjection. Paris: Édition du Seuil, 1980, 12-13.

${ }^{86}$ Esse alucinante raciocínio aguçava o inflamado discernimento persecutório do Dr. Streicher que delatava o empenho dos judeus em desonrar meninas alemãs o mais precocemente possível: denunciava sem cessar casos de médicos que estupravam suas pacientes entorpecidas por anestésicos. A extraordinária imaginação pornográfica do professor vislumbrou, por fim, na corrupção do corpo feminino, uma chave secreta para uma interpretação global da História. Assinalou o horizonte das lutas sociais a uma prodigiosa fantasia que colocava os judeus e suas indecências no centro da ação. "Basta ler cuidadosamente o Velho Testamente", esclareu. "Ele está pavimentado de prepúcios sacrificiais, genitais que foram extirpados e pessoas se gabando de suas aventuras sexuais, prostitutas indescritivelmente sujas, jovens meninos sendo sexualmente abusados, sodomia, incesto, assassinato, genocídio". Do que extraía a surpreendente conclusão: "as mesmas coisas que sabemos estarem acontecendo na Rússia sob o bolchevismo, o paraíso da humanidade nos dias modernos". THEWELEIT, Klaus. Op. cit., 12, 431.

${ }^{87}$ ADORNO, Theodor W.: HORKHEIMER, Max. Antissemitismo e propaganda fascista in ADORNO, Theodor W. Ensaios sobre psicologia social e psicanálise. Tradução: Verlaine Freitas. São Paulo: Editora Unesp, 2015, 140.

88 SARTRE, Jean-Paul. Réflexions sur la question juive. Paris: Gallimard, 2009, 49-50.
} 
amor, mas um cântico de predestinação ${ }^{89}$. Pois, mais do que Dorothea, Oppenheimer era o objeto principal das preocupações de Faber e Sturm.

Faber trazia consigo os signos de uma impotência enrijecida pelo excedente de virtude. Seu noivado com Dorothea não ultrapassava a situação do idílio assexuado. $\mathrm{O}$ casamento arranjado às pressas pelo pai para a proteger da cobiça de Oppenheimer sequer chegava a ser consumado. $\mathrm{O}$ ariano paradigmático, Faber, era, do princípio ao fim, relegado à marginalidade na elaboração ficcional. Em nenhum momento a narrativa fazia dele um páreo erótico contra Süß. Muito ao contrário, todas as operações da fantasia colocavam a virgem e o judeu num mesmo plano do desejo, como se ela estivesse predestinada a lhe pertencer. Era ela quem recolhia Oppenheimer no seu caminho e lhe abria as portas de Stuttgart. Daí em diante, permaneceu constantemente sob a mira do seu olhar lúbrico. Num gesto insensato, colocou-se à mercê de Süß para salvar a vida do noivo, do que resultou sua perdição.

Nos papéis principais, Ferdinand Marian e Kristina Söderbaum enfatizavam, com seus peculiares tipos físicos, a tensão erótica do encontro carnal proibido entre um judeu e uma ariana. A envergadura corporal de ambos atores, cuidadosamente trabalhada na obra, somava-se às narrativas extradiegéticas de suas personas cinematográficas. A identidade das duas estrelas magnetizava o filme com uma solicitação sexual clandestina. Inferia uma sanção ainda mais obscena de um inconfessável desejo de violência e heterogamia.

Porque se comportava como um perfeito ariano, havia um paradoxo insuperável na assimilação de Süß a uma personalidade cinematográfica. Na medida em que o ofício do ator mobiliza a habilidade em desfazer na representação o limite preciso que o separa de seu personagem, não havia caracterizações mais problemáticas do que a do judeu numa encenação antissemita. O programa de desjudaização da indústria havia expurgado das telas intérpretes cuja procedência ariana não fora plenamente estabelecida ${ }^{90}$. Consequentemente, a convicção ideológica do ator impunha-lhe um duplo

\footnotetext{
${ }^{89}$ RENTSCHLER, Eric. Op. cit., 162-3 e TEGEL, Susan. Op. cit., 140 .

${ }^{90}$ WELCH, David. Op. cit., 12, 82-4.
} 
desafio. Sua performance deveria evitar a estereotipia e o distanciamento caricatural, pois isso reduziria o impacto da propaganda. Por outro lado, não se recomendava a identificação demasiada, sob o risco de que uma interpretação muito atraente arruinasse a mensagem racista ${ }^{91}$. Por isso, Ferdinand Marian recebeu a notícia de sua seleção como protagonista do filme com um misto de amargura e ansiedade ${ }^{92}$. Tinha consciência de que, mesmo que Jud Süß viesse coroar o que até então havia sido uma apática carreira às margens dos grandes filmes, o papel o condenaria a permanecer no detestável limbo da alteridade ${ }^{93}$.

Marian provou a impossibilidade de uma síntese pela qual o ariano pudesse emular o outro racial sem submergir nele. Os elementos negativos de sua performance desvaneceram no élan que confundia o ator com sua personagem. À frente de um elenco de notáveis - Heinrich George, Werner Krauß, Eugen Klöpfer - Marian emprestou um lustro de ídolo de matinê ao vilão ${ }^{94}$. Os críticos louvaram calorosamente esse expediente 95 e a plateia respondeu positivamente

\footnotetext{
${ }^{91}$ Por tudo isso, a perspectiva de interpretar o outro racial, o mais abominável judeu de todos os tempos causou celeuma na indústria cinematográfica alemã. Os atores temiam que a verossimilhança da caracterização lançasse sombras sobre a idoneidade de seu pedigrée ariano, obstruindo melhores oportunidades profissionais. Goebbels se incumbiu de emitir uma nota de esclarecimento atestando a pureza racial dos intérpretes considerados para a parte. Apresentando as mais variadas objeções, os astros esquivaram-se mesmo assim, determinados a não emprestar seu lustro à figura de um hebreu pervertido. Goebbels primeiramente se inclinara para Willi Forst, um dos galãs mais adorados das plateias, associado com tipos suaves e românticos, hábil em operetas e comédias. Mudou de opinião e, em seguida, considerou o monumental Emil Jannings, a essa altura o maior ator do Terceiro Reich. Na inglória busca por um intérprete capaz de sugerir simultaneamente abjeção e erotismo, vários candidatos foram testados, a maioria deles identificados como vilões regulares do cinema alemão: René Deltgen, Paul Dahlke e Siegfried Breuer. Outros, como Gustaf Gründgens, Rudolf Fernau e Richard Häussler argumentaram, nas cortes de desnazificação, que sua recusa ao personagem provia uma evidência de sua resistência ao regime (a asserção, contudo, parece apropriada apenas ao caso de Albrecht Schönhals, cuja careira foi de fato obstruída pelo Ministro). GIESEN, Rolf. Op. cit., 125, 129-31; HULL, David Stewart. Op. cit., 1969, 164-5, STROBL, Gerwin. The Swastika and the Stage: German Theatre and Society, 1933-1945. Cambridge: Cambridge University Press, 2009, 128 e TEGEL, Susan. Op. cit., 135-6, 138.

92 GIESEN, Rolf, Op. cit., 130.

${ }^{93}$ Marian debutou no cinema em 1933 e, nos anos seguintes, apareceu numa dezena de filmes, representando personagens secundários, em geral exóticos vilões: um oligarca cubano em $\mathrm{La}$ Habanera (Detlef Sierk, 1937) e um traidor em Der Fuchs von Glenarvon ("A raposa de Glenarvon", Max Kimmich, 1940). Especializou-se em retratos de homens sedutores e maléficos. Sua estatura elevada, a tez morena, os traços latinos e o olhar penetrante tornavam-no especialmente apropriado ao papel do estrangeiro, do estranho e do perturbado. SINGER, Claude. Op. cit., 171. ${ }_{94}^{4}$ STROBL, Gerwin. Ibid.

${ }^{95}$ Resenhando o filme para o Corriere Padano, Michelangelo Antonioni impressionou-se como "o jogo de suas mãos e de seus olhares, as modulações de sua voz, os movimentos de seu corpo - é tudo perfeito". Rainer Werner Fasssbinder o elegera um dos melhores atores de cinema, numa
} 
à sua presença erótica ${ }^{96}$. $\mathrm{O}$ ator intensificou a sugestão sensual, transitando na contramão do desígnio racista da produção. Tornou o judeu um objeto veementemente sexy. A atmosfera lasciva de suas cenas era um elemento determinante para prover valor de entretenimento à obra, fazendo dela uma mercadoria comercialmente competitiva. Não obstante, a exuberância libidinal do judeu contradizia a unilateralidade da mensagem derrisória que a propaganda tencionava lhe atribuir ${ }^{97}$.

Na subsequente consagração de Marian ao primeiro escalão de astros do Reich, alguns analistas inferiram uma subliminar rebelião da plateia contra as demais representações de sacrifício e repressão do filme. A personalidade pública do ator, antes indefinida, adquiriu a aura da sensualidade e da malícia, a qual transbordou nas suas encenações posteriores ${ }^{98}$. O que atestava a dilacerante ambivalência do seu personagem. Na representação desse ator caucasiano, nem completamente ariana ou judaica, a parte de Süß resistia tenazmente à fixação. Alternava posições, colocando-se num ponto indeterminado entre o eu e o outro99. Apagava, assim, os limites da alteridade. Encetava aquela típica forma de instabilidade na relação objetal e de despressurização de um conteúdo recalcado pelos mecanismos da projeção implicados nos estados preliminares da paranoia ${ }^{100}$. Disso sucedia uma representação que conjurava o judeu como objeto de terror para satisfazer o desejo pelo proibido numa intrigante fusão entre o máximo atraente e o tabu absoluto ${ }^{101}$.

A radiante virilidade emanada por Ferdinand Marian oferecia um

\footnotetext{
lista que incluía Clark Gable e Gary Cooper. TOTEBERG, Michael (org). Rainer Werner Fassbinder: a anarquia da fantasia - ensaios, anotações de trabalho, conversas e entrevistas. Tradução: Sonia Baldessarini, Clóvis Marques. Rio de Janeiro: Jorge Zahar Editora, 1988, 196.

${ }^{96}$ Após sua consagração em Jud Süß, jovens fãs, rememorava Veit Harlan, assediavam o ator com buquês de flores: uma evocação pela qual o diretor pretendia atestar a higidez melodramática de sua obra e, portanto, bastante contestada por seus historiadores. TEGEL, Susan. Op. cit., 141-2.

${ }^{97}$ SCHULTE-SASSE, Linda. Op. cit., 80-1.

98 GIESEN, Rolf, Op. cit., 132.

${ }^{99}$ SCHULTE-SASSE, Linda. Op. cit., 82.

100 FREUD, Sigmund. O caso Schreber, in Obras psicológicas completas de Sigmund Freud Volume XII. Tradução: José Octávio de Aguiar Abreu e Christiano Monteiro Oiticica. Rio de Janeiro: Imago, 1996, 58, 70-5.

101 SCHULTE-SASSE, Linda. Ibid.
} 
formidável contraponto à sua partner, Kristina Söderbaum ${ }^{102}$. Com seu rosto de bebê, seus imensos olhos azuis e sua voz estridente, a atriz consagrou o paradigma da feminilidade nacional-socialista. Era, nos filmes, a eterna mulhermenina, branca como a neve, loura, sempre romântica e modesta, uma criança permanentemente imatura. Os conhecimentos da experiência adulta jamais transformavam suas personagens: essas desapareciam numa morte úmida antes que lhes fosse permitido maturar ${ }^{103}$. Nos filmes que realizaram juntos, Veit Harlan usualmente encerrava as agonias de Söderbaum afogando-a no fundo das águas de um lago ou de um rio. Ele apreciava imensamente submergi-la em turbulentas correntes líquidas, produzindo uma imagem peculiar da nudez purificada num batismo letal. Pela insistência nesse motivo visual, Söderbaum passou a ser referida na indústria de cinema alemã como die Reichswasserleiche, o cadáver d'água do Reich ${ }^{104}$.

Söderbaum foi a maior atração de bilheterias da história do cinema alemão. Ao todo, seus filmes renderam mais de duzentos milhões de marcos. A habilidosa combinação de sua persona cinematográfica com o estilo e a modulação dos filmes que protagonizou implicavam-na diretamente no âmbito dos valores nazistas ${ }^{105}$. E a exclusiva associação com Harlan fixou a dupla como o casal dourado do cinema alemão. Essa família artística dedicada à arte germânica produzira, além de uma série de blockbusters, três encantadores filhos, o que fixou

\footnotetext{
102 Assim como Zarah Leander, com quem disputava o papel de primeira dama do cinema alemão no Terceiro Reich, Söderbaum era originária da Suécia. Iniciou sua carreira em 1936 com papéis marginais e pouco promissores. Foi elevada ao estrelato dois anos mais tarde em Jugend (Juventude Ardente) e Verwehte Spuren (Angústia em Paris), ambos dirigidos por Veit Harlan que a desposaria em 1939. Protagonizou mais dez filmes na Alemanha nazista, todos melodramas lacrimosos e extravagantes, dirigidos pelo seu marido pigmalião. ASCHEID, Antje. Hitler's Heroines: Stardom and Womanhood in Nazi Cinema. Filadélfia: Temple University Press, 2003, 84, 86 e ROMANI, Cinzia. Tainted Goddesses: Female Film Stars of the Third Reich. Tradução: Robert Connoly. Roma: La Moderna, 2001, 84-7.

103 SINGER, Claude. Op. cit., 171-2; TEGEL, Susan. Op. cit., 143.

${ }^{104}$ ASCHEID, Antje. Op. cit., 2003, 84, 86-7 e Claude. Op. cit., 172.

105 Söderbaum tornou-se, portanto, um dos alvos preferenciais da crítica antifascista após a Segunda Guerra Mundial. Quando tentou retomar a carreira no palco, os espectadores a hostilizaram, lançando vegetais podres contra ela. Solicitaram que ela e seu marido se retirasse da sala de exibição na estreia de um filme de 1947. Entre um público menos politizado, não obstante, sustentava uma imbatível notoriedade. Ainda em 1953, a despeito do fracasso de suas produções recentes, permanecia como a segunda estrela mais popular do cinema alemão: o que sugeria que seu carisma envolvia algo mais indefinido e duradouro do que as exortações misóginas do regime nazista. ASCHEID, Antje. Op. cit., 43-4.
} 
a imagem de Söderbaum na fronteira extrema do feminino: esposa fiel, mãe dedicada, artista consagrada. Sua presença num filme arrastava, então, uma narrativa extrafílmica, uma bem-sucedida história de Cinderela cinematográfica que a precedia e se estendia à ficção. A fábula paratextual penetrava profundamente nos textos melodramáticos das obras. Não era, por isso, uma superstar que o público pedia, mas uma garota verdadeira, uma filha do campo e da terra, sem afetação ou pose de diva - robusta na forma e no caráter, bucólica, pueril, descomplicada: o mito do Blut und Boden numa formosa Gestalt ${ }^{106}$.

Sua predisposição para o infantilismo acomodava-se esplendidamente à moldura do desejo desenhada pelo sexismo fascista. Söderbaum caiu nas graças do público com caracterizações da viçosa e ingênua Fräulein alemã. Suas personagens remetiam a um imaginário do feminino firmado à distância pelo Romantismo. Eram um compósito de sentimentalismo, autodoação, disciplina e retidão. Graciosas, dinâmicas e românticas, recebiam os sofrimentos com resignação e submissa doçura. Mais atléticas do que sensuais, admitiam os galanteios entre o decoroso rubor e um sorriso encabulado. Produziam uma presença inocuamente erótica, ideal para melodramas concentrados nos temas da perda e do abandono, quando seu estoicismo beirava o limite do masoquismo. Com suas paixões dessexualizadas, Söderbaum vivia entre o martírio e a morte. Dela não se aceitava menos do que a apaixonada resignação às mais extraordinárias privações. Quaisquer que fossem seus sacrifícios, suas personagens eram sempre frágeis demais para triunfarem. A atriz ilustrava, assim, a miséria da condição feminina: ensinava às mulheres as virtudes que deveriam cultivar para atravessarem os padecimentos da época da guerra. Oferecia uma encarnação ostensivamente kitsch da misoginia fascista para consumo das massas. Sem jamais deixar de interpretar a vítima incapaz de tomar as rédeas do próprio destino, ela sequestrava o imaginário da plateia para devolver-lhe a fantasia da autodestruição ${ }^{107}$.

Na caracterização de Söderbaum em Jud Süß, Dorothea Sturm podia se 
comportar como uma variante da graciosa e platinada sonâmbula contanto que não negligenciasse seus deveres de autopreservação para o bem comum da raça ariana. Pois a tragédia da miscigenação, explicavam luminares como o Dr. Streicher, mutilava uma mulher para o resto de sua vida. Inutilizava seu propósito de parir uma estirpe imaculada. O coito interracial fazia dela uma coisa deteriorada, uma criatura dialeticamente morta. Deslindava seu impasse de objeto parcial, ao mesmo tempo bom e mau. Porque a mulher era predisposta à corrupção, no seu corpo se dramatizava a degradação da sociedade. E, porque carregava consigo a possibilidade da heterogamia, sua vida podia ser sacrificada para erradicação do outro étnico ${ }^{108}$.

Nos seus múltiplos papéis de sedutor, cáften e violador, esse único judeu, Süß, arrastava consigo o fantasma da emasculação. Trouxera a Stuttgart uma turba de semitas desgrenhados na qual praticamente não se divisavam mulheres. A massa eminentemente masculina acentuava a atmosfera de ameaça sexual da qual Oppenheimer constituía o principal porta-voz. Sua violência contra Dorothea devolvia ao conselheiro Sturm a advertência de que "judeu algum jamais poluiria uma virgem do meu país". E, como tudo mais, o grande crime que o filme lhe imputava nunca aconteceu na realidade (Dorothea, de qualquer maneira, não passava de uma personagem fictícia). Toda sequência de sevícias era parte de sua lenda, maximizada para firmar a fantasia sádica num registo melodramático impactado pelo tabu racial ${ }^{109}$. De tal maneira que todas as ilações de fundo sexual figuradas no filme eram construções ficcionais - como tais, cotejavam o plano de uma fantasia encenada sobre o corpo da mulher. O estupro encimava todas as transgressões de Süß. Demarcava o máximo limite de seu desafio ao patriarcado ariano. Roubava-lhe seu principal patrimônio - as mulheres com as quais os pais poderiam seguramente legar a herança impoluta

\footnotetext{
108 ASCHEID, Antje. Op. cit., 61.

${ }^{109}$ Historicamente, o inquérito de 1737 não averbou contra Oppenheimer nenhum delito sexual. Nenhuma dama de Württemberg veio à corte de justiça para o acusar de afrontas à sua honra. Em sua época, não houve, outrossim, nenhuma invasão de Württemberg por falanges de maltrapilhos judeus. Somente duas famílias haviam sido autorizadas a estabelecer residência em Stuttgart. LEISER, Erwin. Op. Cit., 81 e SINGER, Claude. Op. cit., 127-9, 136.
} 
do sangue aos legatários legítimos da raça ${ }^{110}$.

$\mathrm{Na}$ afirmação da ascendência do arianismo em sua versão burguesa, Dorothea assinalava o flanco frágil das disputas. Seus deficientes instintos raciais atraíam infortúnio para si e uma catástrofe a Württemberg. Desde o princípio, ela demonstrava inclinações pouco promissoras para se conformar aos domínios da Heimat, no seu duplo sentido de "lar" e "pátria". Seu sincero interesse pelo cosmopolitismo de Oppenheimer e pelos enredos de suas variadas viagens indicava um insuficiente discernimento de seu efetivo papel social de filha e futura esposa burguesa. Sua extraordinária inocência era o código misógino para a desnudar como uma criatura pouco inteligente, imprudente e incapaz de julgar suas próprias inaptidões. Tamanha vulnerabilidade a condenava a permanecer sob a tutela masculina ou perecer nas mãos de um debochado ${ }^{111}$.

Orbitando em torno de múltiplos subenredos, Jud Süß alcançava o clímax narrativo no momento da Rassenschande, a desonra racial. A violência sexual atingia Dorothea na sua dupla condição de esposa e virgem. Seu corpo era, nesse evento, simultaneamente político e biológico, o local onde se regulamentava a vida para produção de sujeitos úteis na plenitude de suas forças produtivas. Perfazia aquele simbólico território em que, observou Foucault, instaurava-se o biopoder ${ }^{112}$.

Por consequência, uma vez subtraído de sua pureza, perdia o valor em ambos os domínios. Não servia, então, mais como heroína para enfrentar a morte no martírio da luta. Desse modo, a fantasia ficcional necessitava se desfazer dela não como uma pessoa, mas como uma coisa. Somente morta, voltava a ser necessária. Adquiria a grandeza de um monumento. Recuperava seu lustro, agora maximizado como um objeto imaginário. No instante em que a trama produzia seu cadáver, sua beleza era tanta que despertava o subjugado macho ariano. Recordava, com sua petrificada presença, que a morte honrosa remia a

\footnotetext{
110 SCHULTE-SASSE, Linda. Op. cit., 55.

111 TEGEL, Susan. Op. cit., 139, 143.

112 FOUCAULT, Michel. Em defesa da sociedade: curso no Collège de France (1975-1976). Tradução: Maria Ermantina Galvão. São Paulo: Editora WMF, Martins Fontes, 2010, 206, 209 e FOUCAULT, Michel. Segurança, território, população. Tradução: Eduardo Brando. São Paulo: Martins Fontes, 2008, 3-4.
} 
corrupção ${ }^{113}$.

Além do fulminante ataque cardíaco que abateu Karl Alexander, duas mortes brutais, a de Dorothea e a de Oppenheimer, demarcavam os picos narrativos de Jud Süß $\beta^{114}$. A ficção produzia, assim, dois corpos martirizados sobre os quais desencadeava a crueldade sádica. Pela dupla violência, inscrevia, numa síntese dramática, o antissemitismo e a misoginia. Na estrutura da trama, uma agressão complementava a outra.

Num filme penetrado pelo imaginário teológico, o cadáver de Dorothea irrompia em cena como um verdadeiro milagre. Era ela simultaneamente o Doador e o Objeto Mágico. Matando-se, a jovem remetia ao herói o instrumento maravilhoso com o qual ele desmascarava o adversário judeu. Seu corpo sem vida absorvia os poderes de mistificação de Süß, tornando-o impotente diante da multidão. Em torno dele, a comunidade recobrava suas forças na mesma medida em que o inimigo se dessubstanciava. Morta, Dorothea tornava-se o perfeito objeto do sadismo. Sua sensualidade foi desencadeada por uma modificação no seu status essente. Reaparecia como que libertada de um encantamento, uma Bela Adormecida vista às avessas. A destruição de sua vida resgatou o que havia de humano nela. Tornou-a indestrutível. Alcou-a, na sublimada forma cadavérica, ao máximo estoicismo. Por trás da sua rigidez, pulsava agora um corpo dentro do seu corpo, o corpo sublime decantado por Sade que transcendeu os piores tormentos, permanecendo imaculado, ressurgindo mais belo a cada gesto de violência115.

\footnotetext{
113 TEGEL, Susan. Op. cit., 145.

114 Um par de figuras paternas disputavam a ordem simbólica no filme: o Duque e o edil. Contra o governante depravado, o conselheiro afirmava o primado da lei em toda sua gama de modalidades, dos ensinamentos luteranos ao Judenbann, o interdito aos judeus. Sturm e Karl Alexander se contrapunham como, respectivamente, o patriarca benigno e o freudiano pai da horda. Por conseguinte, a morte do regente inaugurava um novo pacto social. Sturm restaurava a norma depois de uma série de decisões calamitosas que levaram Stuttgart à rebelião e sua família à destruição. Na imagem da sua serena compostura de legislador desapareciam suas deficiências pregressas. Proclamando a lei, voltava a ser o pai poderoso e, assim, a ficção preenchia a lacuna de suas imperfeições como líder e patriarca. Na terminologia lacaniana era Sturm o derradeiro Nome-do-Pai, a representação fálica que, colocada estrategicamente no local da entidade paterna, criava a função do patriarca. LACAN, Jacques. Des Noms-du-Père. Paris: Éditions du Seuil, 2005, 55, 68-9 e LACAN, Jacques, O seminário, livro 5: as formações do inconsciente. Tradução : Vera Ribeiro. Rio de Janeiro : Zahar, 1999, 162, 165, 174-82, 186-7.

115 BATAILLE, Georges. Sade in BATAILLE, Georges. A literatura e o mal. Tradução: Fernando
} 


\section{Fantasia expressionista}

$\mathrm{Na}$ sua vertente totalitária, observou Marcuse, a doutrina fascista reivindicava a primazia do arcaico sobre o moderno. Rejeitava o racionalismo, o individualismo e o materialismo em prol dos afetos universais. Em torno do tripé ideológico do organicismo, do naturalismo e do existencialismo, o fascismo alemão se empenhou para erradicar a autonomia intelectual de seus aderentes ${ }^{116}$. Para que funcionasse estavelmente, um dos seus mais notáveis triunfos foi levar até as últimas consequências uma racionalidade de supervisão inscrita nos próprios indivíduos, dispensando-se dos custosos aparatos de vigilância. Porque usurpou a dimensão da racionalidade, o fascismo comprometia as faculdades criativas dos seus sujeitos, incapacitando-os de prefigurarem programas alternativos de experiência comunal. Condicionava-os, assim, a coabitarem num mundo sinteticamente empobrecido e a se identificarem de maneira automática com a existência imposta ${ }^{117}$.

Desse modo, o sujeito psiquicamente constituído pelo nazismo foi o ponto culminante de um longo processo de engendramento das técnicas de poder baseadas num ideal de transparência total, pautadas na singular forma do panóptico oitocentista118. "Política é a exibição de uma medialidade", assinalou Giorgio Agamben, "o tornar visível um meio como tal". Consequentemente, ela não comporta um fim em si. Trata-se, antes de tudo, de um percurso que informa a posição fixa do poder em uma dada sociedade ${ }^{119}$. Daí, a concatenação de um paradigma mediático da política a uma modalidade escópica de exercício do

Scheibe. Belo Horizonte: Autêntica Editora, 2015, 109, 113, 120.

116 MARCUSE, Herbert. Negations: Essays in Critical Theory. Londres: Mayfly Books, 2009, 1-3.

117 MARCUSE, Herbert. One-dimensional Man: Studies in the ideology of advanced industrial society. Londres e Nova York: Routledge, 2002, 5-10, 253-5.

118 O panóptico, considerou Foucault, consistia numa idealística estrutura de vigilância, uma tecnologia de poder baseada na total supervisão do olhar externo. Inspirado na utopia das revoluções liberais, pretendia eliminar as zonas obscuras do poder na sociedade. Almejava uma transparência radical na qual a verdade estivesse sempre disponível à inquirição. Funcionava como uma máquina de exposição permanente do sujeito ao olhar. Nele, cada homem se portaria como o vigia do outro. A situação de supervisão, dessa maneira, jamais cessava: todos, na realidade do panóptico, observavam tudo o tempo inteiro e, ao mesmo tempo, eram o objeto da observação alheia. FOUCAULT, Michel. Microfísica do poder. Tradução: Roberto Machado. Rio de Janeiro: Ediç̧̃es Graal, 2004, 210-1, 215-9.

119 AGAMBEN, Giorgio. Meios sem fim: notas sobre a política. Tradução: Davi Pessoa. Belo Horizonte: Autêntica Editora, 2015, 107. 
poder encontrou em Jud Süß uma figuração própria, não apenas na composição dos seus ambientes, mas, fundamentalmente, na caracterização de seu protagonista. Oppenheimer, em suas polimórficas manifestações, dava materialidade a uma concepção eminentemente totalitária da soberania e da práxis regimental.

Numa cultura totalizada, o olhar é sucedâneo do poder - ele discerne, controla, legisla, sanciona. Pressupõe-se a potência da totalização pela habilidade do regime em modelar o campo visual de seus sujeitos, revelando, edulcorando ou subtraindo dele uma fração da realidade, impondo-a, se necessário, como espetáculo, fazendo-se tangível por trás dos seus instrumentos de controle. A política totalitária se desvendava na exterioridade: por intermédio dela, o poder impressionava. Duplicava-se como matéria visível pela qual o observador subentendia as desinências não verbalizadas da propaganda. Consequentemente, uma politização do drama como aquela solicitada em $J u d$ Süß somente se resolveria pela restauração das relações de poder visual. Oppenheimer precisava ser destituído de sua posição de observador privilegiado para que a narrativa pudesse enfim se encerrar ${ }^{120}$.

A primazia da supervisão era, no desfecho do filme, restituída à coletividade masculina enquanto a autoespetacularização do judeu cortês voltava-se vingativamente contra ele. Objeto dos olhos dos cidadãos de Stuttgart, Oppenheimer decaía na degradante situação de objeto submisso da observação alheia. Foi, até aquele momento, o império do olhar que Süß encetara. Não somente penetrava qualquer espaço com seus olhos aquilinos, mas, conjurando uma aparência fulgurante, atraía para si todas as atenções em operações quase hipnóticas. Surgindo em cena simultaneamente como o enunciador do drama, o espectador absoluto e o magnético objeto do seu próprio espetáculo, Oppenheimer ocupava assim uma ambígua posição. Era ele, na acepção do termo, a própria Coisa ${ }^{121}$.

A Coisa freudiana - das Ding - o objeto do mundo que escapou à

\footnotetext{
120 SINGER, Claude. Op. cit., 157.

121 SCHULTE-SASSE, Linda. Op. cit., 1996, 66-7.
} 
representação, que não coube na palavra e não se produziu pela linguagem ${ }^{122}$. Na cena que imediatamente antecedia a entrada de Oppenheimer na trama, Jud Süß levava seus espectadores ao gueto de Frankfurt para ali os lançar sem rodeios numa vertiginosa aproximação dessa deslizante Coisa. Três judeus apareciam alternadamente na sequência. Do alto de uma janela, o Rabi Loew conversava com um açougueiro kosher na rua, enquanto o secretário de Süß, Levy, recebia o emissário do Duque. O efeito sincrônico surpreendia porque, emparelhado na montagem, o celebrado ator Werner Krauß representava ao mesmo tempo os três personagens ${ }^{123}$. $\mathrm{O}$ arranjo horizontal das tomadas permitia ao intérprete $\mathrm{o}$ desmembramento da figuração para expor, numa expressão originalíssima, a atordoante gama de formas presumidas no judeu. Não promovia apenas o ladino gracejo de um performer contracenando consigo mesmo. A horizontalidade dos planos incidia na perturbadora fantasia de que, por trás de suas muitas aparências, o hebreu mantinha uma renitente essência, uma personalidade integral, desdobrada em multíplices variedades, fracionada nos jogos da fisionomia, mas perceptível ao olhar mais acurado. Pois a audiência reconhecia de imediato, sob as extravagantes caracterizações, a invariável presença do polivalente Krauß, vivenciando o gozoso engodo do mascaramento que a doutrina atribuía ao caráter dos judeus.

Um significante sem significado, a Coisa se posiciona exatamente como esse corpo estranho que perturba a ordem da existência, pois insiste em fugir a qualquer possibilidade de ancoragem pela simbolização ordinária. No plano do real, escancara o buraco no Outro e, portanto, sua manifestação precedia usualmente uma experiência traumática, o recalcado no momento em que

122 A Coisa se distingue como a presença sensível de uma ausência. Foi a experiência que permaneceu, desde os tempos da simbolização primitiva, à margem da mediação dos princípios do prazer e da realidade. Porque não se conteve num contorno figurativo, não pode fornir uma prova de sua existência, ou seja, não assegura a mesma percepção de si mais do que uma vez. De tal maneira que somente é experimentada como um momento de alucinação. Torna-se, por isso, o "suporte de uma aversão", o ponto de fuga no qual o desejo escapou, a fissura onde o gozo diante do objeto excedeu qualquer possibilidade de contenção. LACAN, Jacques. Seminário, livro 7: a ética na psicanálise, 1959-1960. Tradução: Antônio Quintet. Rio de Janeiro: Zahar, 2008, 67-8, 70, 80 e LAPLANCHE, Jean; PONTALIS, J.-B. The Language of Psychoanalysis. Tradução: Donald Nicholson Smith. Londres: Carnac Books, 1988, 449.

${ }^{123}$ LEISER, Erwin. Op. cit., 84; RENTSCHLER, Eric. Op. cit., 161 e SCHULTE-SASSE, Linda. Op. cit., 1996, 79. 
retorna. Identifica-se, por isso, com a categoria do puro negativo e, por extensão, com o mal radical ${ }^{124}$.

No projeto geral de Jud Süß, um grande desígnio norteava a trama: a localização do outro racial definido nos termos de uma insuperável diferença, o que descolocava o drama histórico ao horizonte mais sutil do filme de terror. Pois, familiarizando-o à dimensão da Coisa, a trama coloria Oppenheimer em tonalidades menos humanas e mais monstruosas. Nos interstícios dos acontecimentos, Süß se definia pelas diferenças (biológica, social, cultural e econômica). Ocultava sua verdadeira natureza, mimetizando o comportamento de suas vítimas, subtraindo-lhes do campo perceptivo sua degenerescência inata. Seus poderes, se não sobrenaturais, eram, para tanto, mais do que ordinários. Aproximava-se, assim, da alteridade irredutível do monstro do filme de horror, centro formal das atenções nessa categoria de cinema. Enquanto tal, alinhava-se a uma momentosa tradição cinematográfica alemã, a da fantasia de cunho expressionista $^{125}$.

O status da Coisa jamais estaciona numa forma: sua condição é a cambiante situação anamórfica e, como tal, somente pode ser representada quando entrevista de uma mutação a outra. Por trás das múltiplas personalidades de Oppenheimer - dandy, metteur en scène, aristocrata, cosmopolita - o drama almejava, então, produzir a revelação da "verdadeira" face do semita, surpreendendo-o no exato momento de sua metamorfose ${ }^{126}$. Assim, o filme o distanciava das estereotipias das realizações do primeiro ciclo antissemita. Pois sob fisionomias inconstantes, Oppenheimer ocultava uma natureza impenetrável. Era, cinematograficamente, um judeu atípico. Daí que sua

124 ŽIŽEK, Slavoj. Looking Awry: an Introduction to Jacques Lacan through Popular Culture. Cambridge e Massachusetts: October Book/ Massachusetts Institute of Technology, 1991, 161-2. 125 SCHULTE-SASSE, Linda. Op. cit., 62.

126 Uma figura de estilo bastante frequente nos filmes nazistas, observou Eric Rentschler, os fades conviam em variáveis solicitações ideológicas. Faziam evaporar as formas imediatas, destituindoas de sua existência concreta no tempo e no espaço. Assimilavam eventos a fenômenos naturais, acentuando a figuração de um homem revigorado pela conversão da História em Natureza. Produziam um efeito de liquefação do momento histórico, anulando o tempo presente, transportando a situação imediata para outra época. Os corpos de protagonistas mortos fundiamse a símbolos da eternidade inscritos na pedra (máscaras mortuárias, tumbas, monumentos, pinturas). Os fades formalizavam uma transfiguração da criatura viva na matéria inanimada em uma penetrante representação visual da pulsão de morte. RENTSCHLER, Eric. Op. cit., 155. 
desonestidade interpelasse não apenas ao racismo, mas também a outros estratos da fantasia ${ }^{127}$. E essas, no grande desígnio da obra, demandaram soluções originais de sutura das partes e dos gêneros discrepantes. Uma delas foi a orientação da montagem horizontal que distribuía a presença ubíqua de Werner Krauß nos mais diversos cenários da trama. E outra, o sistemático uso de fades ${ }^{128}$.

Reincidentes em Jud Süß, as suturas pelo fade governavam as passagens das cenas mais significativas ${ }^{129}$. Ali, os efeitos de dissolução determinavam intrigantes possibilidades semânticas. Sugeria que dois conteúdos divergentes foram neutralizados numa única instância visual. Impunham uma relação arbitrária de nexo pela qual a segunda figura informava o efeito causado na primeira. O conteúdo manifesto dessa, então, infectava os espaços da outra, ali se alojando, persistindo nela em estado de latência.

Os fundos encadeados pelo fade expunham, desse modo, uma intencionalidade estética para oferecer respostas ideológicas ao problema da fixação da alteridade. Marc Ferro localizou quatro passagens significativas calcadas nessa técnica. Na primeira, logo no início do filme, o emblema ducal do palácio se transformava nos caracteres hebraicos inscritos na placa de Oppenheimer em sua residência na Judengasse. Em seguida, uma transição similar apresentava a impressionante mutação física de Süß, primeiramente caracterizado como um típico judeu do gueto e, agora, transmutado num gentil cavalheiro. O terceiro encadeamento apresentava o advento do corpo de bailarinas da corte a partir das moedas do judeu: demonstrava visualmente como Süß introduziu, no seio do meio político, o gosto pelo deboche, a noção de que qualquer prazer podia ser medido pela escala do dinheiro e o esvaziamento das

\footnotetext{
127 SCHULTE-SASSE, Linda. Op. cit., 59.

128 RENTSCHLER, Eric. Op. cit., 159-60.

${ }^{129} \mathrm{Na}$ constituição da significação visual de um filme narrativo, a noção de sutura desempenha um papel determinante na decifração do sentido. Ela delimita o horizonte do enunciado, preenchendo os campos ausentes entre um plano e outro. Absorve os significados unitários de cada tomada, de tal modo que nenhuma imagem adquire sentido autônomo. Na relação entre dois quadros, a sutura funciona como o grafema de soma: ela totaliza o conteúdo geral da sequência. Trata-se, portanto, de um artifício de continuação que orienta o espectador, conduzindo a interpretação a cada momento da encenação. A posição dos personagens no espaço, a orientação de seus olhares no plano e todas as técnicas de continuidade se qualificam, portanto, como suturas. AUMONT, Jacques; MARIE, Michel. A análise do filme. Tradução Marcelo Felix. Lisboa: Ediçoes Texto\&Grafia, 2013, 228-9, 231.
} 
mulheres de seu conteúdo moral, reduzindo-as à condição de mercadorias. Finalmente, quase perto do encerramento, o elegante Oppenheimer, uma vez desmascarado pelos rebeldes da Dieta, desvanecia e, em seu lugar, despontavam os contornos de um homem degenerado, sujo, mal barbeado e com o tórax semidespido diante do tribunal de acusação ${ }^{130}$.

$\mathrm{Na}$ retórica antissemita, os fades dramatizavam a extensão do perigo judaico. Informavam, melhor do que qualquer panfleto, a artificialidade da camuflagem do inimigo. Mantinha em suspensão a face semita oculta sob todos os disfarces. Semanticamente, a fusão marcava um momento de desrealização. Provia uma aproximação visual do sortilégio pelo qual Oppenheimer extinguia a substância das coisas reais para as preencher com um simulacro, iridescente por fora, mas oco por dentro ${ }^{131}$. Era no campo da aparência que Süß exercia seu poder. Sua superioridade decorria desse estranho Schein no qual Adorno denunciou os limites possíveis da reificação e da pura exterioridade cujo lustro, fulgor ou luminescência perturbavam o imediatismo do objeto, sobrepondo-lhe uma camada opaca que apagava o trabalho sobre a matéria ${ }^{132}$.

A sutura pela transparência e fusão investia a política de aparência e desmascaramento do regime nazista de uma forma fechada e legível. Modulava, como um mágico espelho policial, as duas faces do judeu. Expunha sua realidade de ente pervertido porque jamais era idêntico a si mesmo. Posto que se imputava uma clivagem entre a forma pela qual se apresentava e o conteúdo de sua personalidade, ele desfazia o laço congenial que unia a presença visível à essência

\footnotetext{
130 FERRO, Marc. Cinéma et histoire. Paris: Gallimard, 2009, 160-1.

${ }^{131}$ Essa mesma opção de assimilação fusional estendia-se da montagem visual à trilha sonora. A música filtrava as instâncias de raça, impondo motivos sinistros nas cenas de massa figurando judeus. As canções a eles associadas evocavam uma mistura e exotismo, dissonância e primitivismo. À cena da suspensão do Judenbann seguida da entrada dos hebreus pelos portões de Stuttgart, sobrepôs-se uma estranha melodia vocal. A monódia acentuava a defasagem e a estranheza daquela horda de maltrapilhos que invadia a cidade dos arianos. Dela se inferia uma atmosfera agourenta. Contrastava violentamente com o tema romântico de Dorothea e Faber. A canção de amor acompanhava as entradas da filha do edil em cena, muitas vezes precedida ou seguida pelo lamento hebraico. A montagem sonora reforçava assim o desequilíbrio visual nas representações do meio ariano quando ameaçado pela iminência da presença judaica. SINGER, Claude. Op. cit., 153-5 e TEGEL, Susan. Op. cit., 140.

132 ADORNO, Theodor W. Teoria Estética. Tradução: Arthur Mourão. Lisboa: Edições 70, 2013, 159-64, 167, 170.
} 
subjacente. Oppenheimer obliterava o jogo especular de reprodução passiva de uma índole serena numa aparência agradável. Instaurava uma odiosa dualidade sobre a epiderme do perceptível, ocultando o vício invencível por baixo da transcendente fisionomia da beleza. Nas oscilações do seu semblante, Süß provia uma morfologia facial para representar a instabilidade do sujeito moral. Inscrevia, com sua presença, uma anatomia do caráter que reconhecia no rosto não apenas as predisposições congênitas, mas também aquela identidade orgânica, atemporal, a-histórica, "natural". O fade tentava insular numa única figura, Süß, o privilégio de quem produzia a doença porque gozava do anonimato. Era, então, um recurso que decompunha, catalogava e reorganizava os dados, produzindo, assim, um inventário para indexação da degenerescência.

Os efeitos de transição pela fusão foram particularmente importantes na arregimentação dos filmes de terror alemães e norte-americanos ${ }^{133}$. Do mesmo modo, pelos fades (e também além deles), nas brechas da encenação muitos eventos figurados em Jud Süß escapavam ao domínio ordinário do melodrama para instaurar a inequívoca atmosfera das narrativas de horror. As cenas que representavam o povo de Stuttgart buscando o corpo de Dorothea nas águas negras do rio e, mais tarde, a turba se arremetendo contra a mansão de Süß, por exemplo, evocavam a plástica iconografia do filme expressionista e essa, indubitavelmente, rescendia as formas típicas do terror ${ }^{134}$.

Um dos gêneros comerciais mais populares e menos nobres do cinema clássico, o filme de terror se notabilizava por suas inovações estéticas, seus peculiares investimentos em diferentes campos da cultura popular e erudita e seus consequentes desvios das normas narrativas tradicionais. Seus analistas reconheceram nele modalidades de representação indireta para fantasias sadomasoquistas. A vertente feminista da teoria fílmica cartografou ali deslocamentos dos padrões ordinários de encenação da sexualidade, de marcação de gêneros sexuais e da experiência espectatorial. Essa categoria de produções promovia aproximações originais, muitas vezes transgressivas de

\footnotetext{
133 SINGER, Claude. Op.cit., 140-1.

134 SCHULTE-SASSE, Linda. Op. cit., 62.
} 
temas usualmente cercados de pudores: a morte, a dor e a perecível realidade do corpo humano. Metaforizava a Coisa em tumbas e criptas violadas, castelos arruinados, decadentes casas mal-assombradas, cadáveres putrescentes retornando à vida, legiões de demônios e monstros e irrupções de todas as formas do fantástico - mortos vivos, criaturas híbridas, meio homens, meio animais, seres disformes e entidades sobrenaturais. Desafiava, ademais, os padrões rotineiros de sublimação estética do recalcado porque rejeitava a cisão entre a alta e a baixa cultura135. Investindo na excitação dos sentidos, na erotização do monstruoso e nas primitivas emoções do medo, da angústia e da expectativa, o filme de terror resgatou um Romantismo exaltado, baudelairiano, pavimentando o caminho para a ruptura modernista ${ }^{136}$. Foi, portanto, o ponto de partida do cinema avant garde, em especial nas linhagens surrealista e expressionista pelas quais a arte elevada europeia reencontrou uma manifestação imediata e afirmativa para estetização do unheimilich.

Unheimilch: essa categoria que se apresentava como o "estranho", Freud constatou, sintetizava a condição incerta do descarnado revivido, do obscuro manifesto, do inacessível exposto, do oculto desvelado. Unheimilich coincidia sempre com seu oposto. Sua condição fundamental era a situação desestabilizadora do duplo. Como tal, indicava a permanência de um resíduo que escapou à significação ordinária e não se dissipou simbolicamente num objeto $^{137}$.

135 Filmes de terror flutuavam numa heterogênea gama de formas populares: histórias românticas, thrillers criminais, ficção fantástica e faits divers sensacionalistas. Mas também afirmavam seu elevado pedigrée artístico prospectando nas mais excelsas referências, em especial a literatura gótica dos Oitocentos em alguns de seus momentos seminais - Drácula de Bram Stoker, Frankenstein de Mary Shelley, O Médico e o monstro de Robert Louis Stevenson, Os assassinatos da Rua Morgue de Poe e O retrato de Dorian Gray de Wilde - e também se ancorando na celebrada tradição do Grand Guignol. NEALE, Steve. Op. cit., 93-4.

136 NEALE, Steve. Op. cit., 94-5.

137 O termo alemão (derivado negativo de heimlich, "doméstico", e heimich, "nativo") designava um significado impossível, o "infamiliar". Incidia naquilo que escapou à órbita das coisas ordinárias, revelando uma face inédita e insólita. Num sentido equivalente, implicava o "desdomesticado", apontando o que dissimulava, sob o verniz da docilidade, uma essência violenta e hostil. Unheimilich marcava a súbita eclosão de um elemento que, até pouco, remanescia escondido. Sugeria a perturbadora contradição do objeto que, antes subtraído dos sentidos, voltou subitamente a ser o que foi. Problematizava a situação de um elemento que deveria ter remanescido retirado do mundo, mas inadvertidamente sobreveio à luz. Daí que funcionasse para qualificação do misterioso, do sobrenatural e do aterrorizante. FREUD, Sigmund. $O$ 
Algo externo, estranho, desconhecido, cuja presença levantava a poeira de maldições mal sepultadas, Süß, na condição de judeu absoluto, obrigatoriamente proveria uma manifestação do unheimlich. Seu aspecto, os gestos, a voz e o olhar situavam-no desde o princípio no campo do estranho. Pois ele era o diabo judeu mercando com o impossível. Por trás da dialética de suas aparências, seu apelo coincidia com as promessas de Mefisto a Fausto ${ }^{138}$. Vendia um sonho atrás do outro e traficava fantasias porque pertencia ao mundo dos entes desumanizados pela exterioridade: nem um homem ordinário, nem uma criatura sobre-humana, mas uma perspectiva em que um estado resvalava no outro.

Fundamentalmente, o unheimlich investe no instante da hesitação. Ali, o status do objeto não pode ser prontamente fixado. Não operando como os demais conteúdos, ele retorna com a energia do que se recusa à pacificação. Nessa situação, a sua irrupção prefigura o retorno de algo recalcado: o prefixo "un" sinalizava justamente um instável estado de repressão ${ }^{139}$. Como tal, assinala a presença de ideias dinamicamente mantidas à margem da percepção consciente por manobras de resistência que obstruem seu afloramento. A repressão pressiona o ego sem que esse se dê conta dessas transações. Somente quando recrudescem os trabalhos psíquicos contra o ressurgimento dos conteúdos represados, o ego intui a realidade repressiva, experimentando-a como motivo de desprazer, ansiedade e angústia. Doravante, a repressão evolve para o recalque ${ }^{140}$.

Os crimes sexuais do obsceno pai primal, a orgia incestuosa, o parricídio, o canibalismo da fraternidade homicida, a ressureição bestializada do patriarca e a culpa edípica - no mito cientifico da horda primitiva, Freud localizou essa condição fundamental da sociedade humana, o recalcado, naquele patriarca que não foi perfeitamente enterrado e, por isso, sempre retorna ao mundo dos vivos

'estranho', in Obras psicológicas completas de Sigmund Freud Volume XVII. Tradução: José Luiz Meurer. Rio de Janeiro: Imago, 1996, 235-42, 246, 250, 252, 261.

138 RENTSCHLER, Eric. Op. cit., 164.

139 FREUD, Sigmund. Op. cit., 256, 266.

140 FREUD, Sigmund. O ego e o id, in Obras psicológicas completas de Sigmund Freud Volume XIX. Tradução: José Octávio de Aguiar Abreu. Rio de Janeiro: Imago, 1996, 28, 36, 38. 
como espectro, miasma ou assombração ${ }^{141}$. O retorno do recalcado constitui, portanto, um caso paradigmático em que uma história de terror foi instruída como uma narrativa mestra de todo gênero humano. Descrevendo os signos da violência originária - o incesto, a castração, o parricídio, a antropofagia - o terror define então a própria ambivalência da condição humana ${ }^{142}$.

Na forma do enforcamento de Oppenheimer, em Jud Süß se afigurava um similar espetáculo metafórico do parricídio. A cena igualmente inventariava num palco dramático e político o contrato social pelo qual uma comunidade reprimia sua violência, ritualizava a morte e renunciava à condição da natureza. Até ali, Süß fora a perfeita encarnação de um indecente pai da horda. Predou todas as mulheres e depredou todos os recursos. Castrou simbolicamente seu rival sexual, Faber. Sua violência desafiava qualquer noção eficiente de civilidade, pois ela perseguia satisfações primárias e desconhecia os limites pactuados numa ordem social estável. Era então uma manifestação esplêndida do primitivo no seio da modernidade. Oppenheimer pertencia a um obscuro reino de trevas que a cultura sempre mourejou para esconjurar. Adotando as soluções referendadas pelo gênero fantástico, somente a morte exorcizou do corpo do malfeitor o incansável demônio nele encarnado. A sua eliminação física restabelecia o equilíbrio espiritual da comunidade, abrandava as emoções, pacificava a massa, contendo dentro do quadro o mundo das sombras expressionistas. A natureza rebelada que Oppenheimer arrastava consigo enfim fora represada, fixada e, mais uma vez, recalcada ${ }^{143}$.

No domínio que lhe é pertinente, uma ficção de terror dramatiza a erradicação da criatura fantástica, na qual uma dupla condição política do homem - ser natural e social - conflituosamente convivem. Trata-se então de uma elaboração que cinde e fixa pela excisão do paradoxal ${ }^{144}$. Aponta uma solução

\footnotetext{
${ }^{141}$ FREUD, Sigmund. Totem e tabu: algumas concordâncias entre a vida psíquica dos homens primitivos e dos neuróticos. Tradução: Paulo César de Souza. São Paulo: Penguin Classics, Companhia das Letras, 2013, 147-53.

142ŽIŽEK, Slavoj. Op. cit., 36.

143 SINGER, Claude. Op. cit., 150, 159.

${ }^{144}$ Daí não apenas uma cena do recalque psíquico, mas também uma imagem da fratura política, assombra a ficção de horror. Pois, em criaturas fantásticas como o Wargus (o homem lobo), o friedlos (o desassossegado), o loup garou (o lobisomem), Giorgio Agamben localizou um limiar de
} 
conciliatória, por vezes provisória, para o perturbador fato de que as relações comunais jamais evolveram além da condição fundamental do estado de natureza. O catártico rito de excisão da criatura desviante pretende, assim, desfazer a tensão de uma realidade do mesmo modo aterrorizante. Não exatamente uma fantasia alienante, mas uma formulação do impossível anseio de erradicar o monstro da soberania que impunha a reverência ao poder pelo recurso da violência - enquanto fábula de horror Jud Süß desqualificava o regime de terror. Num investimento contrário à doutrina fascista, o drama desafiava subterraneamente o princípio ordenador do Estado, fazendo desaparecer, no último momento, o máximo símbolo de seu absoluto, irreversível e impenetrável poder, Oppenheimer.

Nesse sub-reptício alinhamento de Jud Süß à categoria do filme de terror, rescendia, por isso, seu parentesco à mais política categoria da cinematografia alemã, aquela que antecedeu o nazismo e nele sobreviveu como o elemento de uma arte degenerada a qual insistia em resistir à nova ordem. Essa mal disfarçada aproximação perfilava Süß à geração de actantes de um cinema que, nos desvairados tempos de Weimar, o sagaz produtor Erich Pommer rotulou como expressionismo alemão.

Uma etiqueta incrivelmente elástica e, por isso, muito pouco elucidativa (toda criação artística, afinal, investe na expressão), a epígrafe expressionismo problematizava a exterioridade da obra, emancipada, dilatada, sublinhada, sublimada ou deformada ${ }^{145}$. O sucesso da campanha de Pommer para promoção da obra que precipitou a série expressionista, Das Cabinet des Doctor Caligari (O gabinete do Dr. Caligari, Robert Wiene, 1920) chancelou a difundida crença de que essa tendência prevaleceu na cinematografia alemã da década de vinte ${ }^{146}$.

indiferença no qual se confundem o homem e o animal, a physis e o nomos, os estados de natureza e de direito. Nem homem, nem fera, elas habitavam concomitantemente dois mundos. Homo homini lúpus - o mitologema hobbesiano perscrutava, nessa forma dual, o princípio interno da soberania política. Do que Agamben aduziu que o estado de natureza não constituía uma situação pré-jurídica ou um momento histórico anterior à civilização, mas a condição política como tal. AGAMBEN, Giorgio. Homo Sacer: o poder soberano e a vida nua I. Tradução: Henrique Burigo. Belo Horizonte: Editora UFMG, 2007, 212-7.

${ }^{145}$ AUMONT, Jacques. L'ceil interminable: Cinéma et peinture. Paris: Éditions Séguier, 1995, 289, 294. 146 AUMONT, Jacques. A imagem. Tradução: Estela dos Santos Abreu, Cláudio Cesar Santoro. Campinas, São Paulo: Papirus, 2012, 305-7. 
Alternativamente, por filme expressionista definiu-se, desde então, uma parábola dark do pós-guerra, uma alegoria niilista da modernidade, um maneirismo psicótico ou qualquer coisa com cenários estranhos, iluminados sob uma luz vacilante, oscilando entre o delírio, o sonambulismo e a hipnose para culminar em desenlaces desoladores ${ }^{147}$.

Num mundo ficcional enquadrado pela perspectiva distorcida, o olhar do cinema expressionista, à primeira vista, parecia remeter ao horizonte da psicopatia. O filtro visual dos protagonistas recortava cenários deformados pela loucura, imaginárias paisagens caóticas, panoramas onde desapareciam os pontos de fuga. Pela estilização dramática, o cinema de Weimar cristalizou um cânone de fracionamento do olhar. De acordo com Thomas Elsaesser, o estilo, porém, não pretendia autentificar uma descrição óptica de estados psíquicos alienados, nem as torturantes mentalidades culturais dos loucos anos 1920. Tratava-se, ao contrário, de um metacinema motivado pela proficiência na construção da imagem em um meio híbrido no qual coabitava o neorromantismo com um modernismo ultratecnológico para entretenimento das massas ${ }^{148}$.

No cinema weimariano, o olhar adquiriu, por isso, um valor metalinguístico. Invocava o próprio aparato pelo qual os filmes se constituíam. Referia-se ao meio midiático, desbotando a linha que discernia o real do imaginário. Seus protagonistas eram não apenas criaturas da noite, mas seres hipersensíveis, transtornados pela brutal habilidade de tudo enxergar ${ }^{149}$. Rodeados de uma aura sobrenatural, encenavam o transfixante sonho mau da sociedade. Protagonizavam baladas sangrentas em cenários espectrais, trocavam de personalidade e deflagravam a miséria como uma orgia sem fim. Eram uma ameaça onipresente, mas que, mesmo assim, não podia ser localizada num lugar preciso. Reverberavam, portanto, uma miragem comunitária governada pelo medo e pelo terror, que, do ponto de vista de Siegfried Kracauer, rescendia

\footnotetext{
147 EISNER, Lotte. Fritz Lang. Londres: Da Capo, 1986, 17-36.

148 ELSAESSER, Thomas. Weimar Cinema and After: Germany's Historical Imaginary. Londres e Nova York: Routledge, 2008, 61, 65-6, 68-78, 82-3, 85, 87, 89, 94, 95-7.

${ }^{149}$ ELSAESSER, Thomas. Op. cit., 62-3, 65, 72, 79.
} 
precocemente ao regime hitlerista ${ }^{150}$. A partir do que os críticos dessa teoria da prefiguração, ao invés de protofascistas, reconheceram ali outras instâncias actanciais: ora a autorreflexão do meio cinematográfico conformada pela metáfora da visão, ora a dimensão da mais extrema negatividade. Encontraram nos supervilões do cinema da época de Weimar os extraordinários articuladores do desejo cuja última encarnação numa forma narrativa clássica desenhada dentro de um projeto de modernização do cinema foi precisamente Süß, o judeu de Württemberg. Sua característica perversidade, tipificada como traço essencial da etnia judaica, evolvia de uma memória expressionista firmemente ancilada na cinematografia alemã. Os filmes de ódio racial não rompiam, portanto, com a tradição do moderno cinema weimariano. Ao contrário, perseguiam-na. Reclamavam-na. Procuravam amparo nela. Atualizavam no judeu uma presença invariante, não um personagem, mas o actante, o mestre do mal, o homemmonstro, o sujeito da pulsão de morte.

Não um conceito, mas uma virtualidade que escorrega pelo percurso narrativo organizando o discurso, no encadeamento lógico da narrativa, um actante constitui uma posição e um papel. Conjuga, simultaneamente, um percurso e um estado do sujeito na trama. Actantes sinalizam uma constelação de forças dinâmicas que incide funcionalmente na composição de uma narrativa ${ }^{151}$. Constituem classes de atores e somente se determinam num corpo de obras. Constroem-se a partir de um feixe de funções passíveis de serem inventariadas e qualificadas numa rede de sentido. Indicam, num corpus de

\footnotetext{
150 KRACAUER, Siegfried. From Caligari to Hitler: a Psychological History of the German Film. Princenton e Oxford: Princenton University Press, 2004, 77-80, 82-4.

151 Actantes perfazem um arranjo de funções - e, por função (em concordância com Vladimir Propp), compreendem-se as unidades sintagmáticas constantes que se manifestam numa diversidade de narrativas. $\mathrm{O}$ actante define aquele que realiza ou sofre um ato, seres ou coisas participantes do processo de sentido. A noção de actante substitui mais rigorosamente o conceito de personagem (as pessoas humanas) ou a abrangente instância de ator (a unidade lexical nominal inscrita no discurso como figura autônoma, seja pessoa ou coisa) definida no caso particular de uma obra. Longe de se comportar como a variável de um actante invariante, um ator pode assumir sucessivamente diversos papéis actanciais. Mas também um único actante pode se manifestar em diversas ocorrências de ator. GREIMAS, Algirdas Julius: COURTES, J. Dicionário de semiótica. Tradução: Alceu Dias Lima, Diana Luz Pessoa de Barros, Eduardo Peñuela Cañizal, Eduardo Lopes, Ignacio Assis da Silva, Maria José Castagnetti Sombra, Tieko Yamaguchi Miyazaki. São Paulo: Contexto, 2013, 20-1, 224, 334-5, 366.
} 
criações artísticas, uma permanência de papéis, um inventário de mensagens funcionais concentradas num mesmo domínio, não importando quantos atores transitam por ele ${ }^{152}$. Daí, Süß Oppenheimer, Levy e os figurantes judeus nem remotamente operavam apenas como personagens nominais ou atores sociais. Eram, prioritariamente, complexos de forças semanticamente orientadas na articulação do sentido da obra. Transitavam em múltiplas tramas reencenando uma grande fantasia alteritária. Por suas origens desviantes, estavam condenados a permanecer nas bordas do Outro. Não lhes era possível participar dos labores ordinários da humanidade - muito ao contrário, sua função como actante os obrigava a atividades extraordinárias. A eles cabia desencadear as incríveis potências da pulsão de morte. Incapazes de sublimar suas tendências associais pelo trabalho libidinal, exprimiam o absoluto ânimo da negatividade. No nível do actante, travestiam-se como inimigos da cultura para assumirem o compromisso de estipular a ação descivilizadora em figurações que escancaravam o recalque a céu aberto. Süß incorria então na mais vigorosa dimensão actante da cinematografia alemã. De Nosferatu a Mabuse, produzia uma reencarnação daquela galeria de déspotas e opressores lascivos do período expressionista, capturando-a e a atualizando nas suas mais sádicas peculiaridades ${ }^{153}$.

152 GREIMAS, Algirdas Julius. Semântica estrutural: pesquisa de método. Tradução: Haquira Osakabe, Izidoro Blikstein. São Paulo: Cultrix e Editora Universidade de São Paulo, 1976, 225-8, 242-3, 247.

${ }^{153}$ De Nosferatu, Süß conservava a característica predatória com a qual levava a barbárie para dentro da civilização, a vampiresca qualidade de se opor à ordem vigente pela luta encarniçada entre culturas, a incrível mobilidade e a aptidão de se adaptar a qualquer ambiente. Do Oriente ambos traziam suas misérias e pestilências. Suas jornadas rumo ao Oeste instauravam acontecimentos ominosos e abomináveis e culminavam na ofensa magistral, a violação da mulher alemã, infectando-a com uma mácula de degeneração. Ritos de purificação tornavam-se assim necessários para expurgar sua presença maligna, não antes que a gentil donzela tivesse se oferecido em sacrifício para salvar a comunidade do flagelo. Por outro lado, de Mabuse, Süß retinha a qualidade polivalente, a maleficência decadentista, o materialismo, a vulgaridade e a erosiva perversão dos desejos. Tal qual o mestre do crime de Weimar, Süß também provia uma face antropomórfica à lógica de abstração e de arbitrariedade que contaminava os meios de difusão de bens e pessoas numa sociedade politicamente vulnerável. Mabuse e Süß deslizavam sobre uma movediça instância actancial: a da negatividade. Emulavam ambos uma energia social regressiva, desdobrada na repetição, no disfarce, na imitação e no logro. ELSAESSER, Thomas. Op. cit., 155, GUNNING, Tom. The Films of Fritz Lang. Londres: British Film Institute, 2000, 94-7, 105, 114-6, MAYNE, Judith. Dracula in the Twilight: Murnau's Nosferatu (1922) in RENTSCHLER, Eric (ed.). German Films \& Literature: Adaptations and Transformations. Nova York, Londres: Methuen, 1986, 27, 29-30, RENTSCHLER, Eric. Op. cit., 156-8, SCHULTE-SASSE, Linda. Op. cit., 
A coloração expressionista que incidia em cena na presença dos elementos judeus não apenas enfatizava o preconceito de que eles recepcionavam a realidade por uma ótica deformada e, a partir dela, produziam uma imagem corrompida e degradada. Servia também para estetizar uma representação bárbara do mundo fazendo-a corresponder àquilo que supostamente o judeu enxergava ${ }^{154}$. Nas formas codificadas tanto pelo filme de terror quanto nas feições do cinema expressionista, uma particular categoria de disfunção psíquica encontrava assim um meio privilegiado de expressão: a paranoia.

O paranoico experimenta o que lhe é exterior nos termos da ameaça. Interpreta os eventos externos como indícios das intenções nocivas de seus inimigos $^{155}$. A sensação de exposição o acompanha em tempo integral. Na sua angústia persecutória, consequentemente, a visão adquire uma perspectiva extrema. O paranoico se vê sendo visto. Encontra olhos que o perseguem em todos os lugares. Cada olhar significa uma ameaça, promete uma agressão, anuncia um sofrimento ${ }^{156}$.

Um dos mais intrigantes aspectos de Jud Süß foi precisamente a construção paranoica do ponto de vista narrativo a partir da perspectiva do vilão. $O$ onipresente e onipotente olhar judeu emoldurava o campo visual franqueado ao público ariano. Longe de pretender a aproximação com o espectador, a fixação unilateral do horizonte da escopia tencionava reforçar o distanciamento. Inferia a pretensão de objetividade na apresentação dos judeus, uma vez que lhes concedia a primazia de enquadrar a narrativa, um privilégio de que

63, 77 e SINGER, Claude. Op. cit., 151, 161-3.

154 SINGER, Claude. Op. cit., 161-3.

155 Na paranoia reconciliaram-se as exigências dos desejos recalcados com as elevadas demandas de um superego rígido. A operação fundamental para harmonização desses domínios antagônicos é a projeção do anseio do sujeito aos objetos que excitam sua mente. A demência desfaz os trabalhos de sublimação, revertendo o investimento afetivo que separava o eu do mundo. Os afetos do paranoico são devolvidos à consciência deformados, como se fossem uma experiência externa. Reativamente, ele então atribui suas sensações interiores aos objetos exteriores. Na sua fantasia, é, pois, o objeto que deseja o seu próprio desejo. FREUD, Sigmund. $O$ caso Schreber, in Obras psicológicas completas de Sigmund Freud Volume XII. Tradução: José Octávio de Aguiar Abreu e Christiano Monteiro Oiticica. Rio de Janeiro: Imago, 1996. 43, 50-2, 58, 70, 73 4 e FREUD, Sigmund, O ego e o id, in Obras psicológicas completas de Sigmund Freud Volume XIX. Tradução: José Octávio de Aguiar Abreu. Rio de Janeiro: Imago, 1996, 58.

156 CANETTI, Elias. Crowds and Power. Tradução: Carol Stewart. Nova York: Farrar, Straus and Giroux, 2013, 456-7. 
Oppenheimer lançava mão para enganar, oprimir, seduzir e conjurar ${ }^{157}$. Em travellings velozes, os olhos de Oppenheimer penetravam os objetos de cima abaixo, do que resultava a peculiar verticalidade dos quadros. A disposição dos enquadramentos estabelecia uma essencial relação estética entre o olhar e o delírio persecutório. Numa sequência, Süß espreitava os conselheiros da Dieta por trás da moldura vazada de uma gárgula. De seu ponto de vista, os poderosos paladinos da burguesia que conspiravam para sua ruína pareciam homenzinhos minúsculos e insuficientes, confinados no canto da cena. Do enquadramento emanava então a forma doutrinária fundamental da paranoia nazista. Nele se produzia uma visão de si como objeto do olhar invasor de um outro todopoderoso. Enquanto devassavam e esquadrinhavam, os olhos do judeu também rebaixavam, degradavam, corrompiam e, por fim, emasculavam os homens. Emparedava-os como alvo passivo do investimento escópico (uma posição, ademais, culturalmente associada ao feminino) ${ }^{158}$.

Dos poderes do olhar cultivados na tradição do primeiro grande cinema alemão, o filme nazista conservou e reforçou essa relação de dominação pela visão. Em variadas realizações do período fascista, o olhar dos protagonistas desviava-se da cena e se fixava na câmera. Assim, desestabilizava até mesmo a audiência, sequestrando-a de seu anonimato na sala de projeção. Fazia dela o objeto capturado na fixação do campo visual do personagem. As pessoas reais da plateia, por esse expediente, eram subitamente colocadas na posição de coisas. Diversas produções comissionadas pelo Estado - particularmente nos Geniusfilme de Frederico II: Der alte und der junge König (Alma mascarada, Hans Steinhoff, 1935) e Der große König (O grande rei, Veit Harlan, 1942) - alcançavam o clímax por meio desse recurso retórico: a absorção do campo extradiegético (no qual o próprio espectador habitava) pela transfixação do olhar ariano. $\mathrm{O}$ personagem encerrava sua trajetória desviando seus olhos do espaço fechado do quadro para os cravar friamente sobre a audiência. As pupilas glaciais, endurecidas pela provação, petrificadas na doutrina, desferiam, então, uma

\footnotetext{
157 SINGER, Claude. Op. cit., 157.

158 SCHULTE-SASSE, Linda. Op. cit., 65-6., 123.
} 
brutal retaliação contra a pulsão escópica do público. Interpelavam diretamente a audiência. Na forma fílmica, era assim estabelecida uma metáfora do panóptico, a qual advertia contra os desejos desviantes, recordando ao espectador que nada mais escapava ao onisciente olho do poder ${ }^{159}$.

Nos dois grandes sujeitos do biopic nazista, Frederico, o rei dos arianos e Süß, o rei dos judeus, a estetização do campo visível coincidia com a retórica ideológica pela qual ver e poder participavam da mesma materialidade. A experiência de tudo enxergar pertencia ao campo de habilidades extraordinárias que somente os dois extremos raciais da humanidade podiam realizar ${ }^{160}$. Nos previdentes olhos de Oppenheimer, havia, portanto, o resíduo de uma potência que até pouco fora exclusiva da excelência ariana. Em Jud Süß, o hebreu enfim aprendera a produzir o mundo pela ótica nazista. A elaboração paranoica do filme escapava ao projeto antissemita para atribuir ao inimigo uma privilegiada competência cognitiva própria à estirpe nórdica. Perversamente, buscando denunciar as perigosas aptidões do judeu, a representação deixava escapar que ele e o ariano tornaram-se ambos portadores do mesmo emblema de poder.

Assinalado no campo da Coisa, do outro e do monstro, Oppenheimer, por fim, desbancava a espetacularização do corpo feminino, a pedra angular do cinema clássico, para se comutar ele próprio no espetáculo161. Um marcador cognitivo do gênero do horror, o vínculo entre a mulher e o monstro na disputa pela primazia do espetáculo fazia dela a vítima preferencial dos ataques da fera. A violência que encontrava nos braços da aberração atestava ao público os riscos implícitos na aproximação alteritária. Para esclarecimento da plateia, a mulher terminava punida pela sua curiosidade ou sua falta de precaução. Na ordem patriarcal, o feminino e o monstruoso marcavam assim a dupla variedade da diferença. Ambos habitavam corpos interrompidos, mutilados e incompletos. Carregavam consigo uma castração originária ${ }^{162}$. Podiam, portanto, ser eliminados sem deixar vestígios de culpa após seu desaparecimento.

\footnotetext{
159 SCHULTE-SASSE, Linda. Op. cit., 122-3, 144, 243.

160 SCHULTE-SASSE, Linda. Op. cit., 123.

161 SCHULTE-SASSE, Linda. Op. cit., 62.

162 SCHULTE-SASSE, Linda. Op. cit., 64.
} 
Mais do que qualquer coisa, a iconografia da aproximação sexual do judeu com a ariana alinhava Jud Süß ao gênero do terror. O estupro efetivava, pelo contágio do sêmen, a mesma degeneração que aquela imputada ao sangue contaminado por um vampiro ${ }^{163}$. Após a selvageria, Dorothea ressurgia no centro das atenções em sua gloriosa forma final de cadáver. Recuperada das águas do rio, a defunta adentrava nos braços de Faber pelos portões de Stuttgart. Uma multidão fantasmaticamente iluminada por tochas abria-lhes caminho. A face pálida e infantil da mulher morta sugeria a transcendência pela qual os homens da cidade subitamente recuperavam sua masculinidade e se lançavam rumo à vingança. Principiava o processo de reversão das humilhações impostas pelo judeu. A narrativa propiciava enfim o prazer de fazer também de Oppenheimer o objeto de um espetáculo de violências até atingir a culminância do enforcamento ${ }^{164}$.

No momento da morte, a mulher e o monstro eram assim consignados à ordem da Coisa, ao estado do informe, à dimensão nirvânica da pulsão de morte. Ela, porém, terminava cristalizada num sofrimento que era a própria inscrição da cultura metaforizada no corpo duplo - social e biológico - da mulher. A alvura
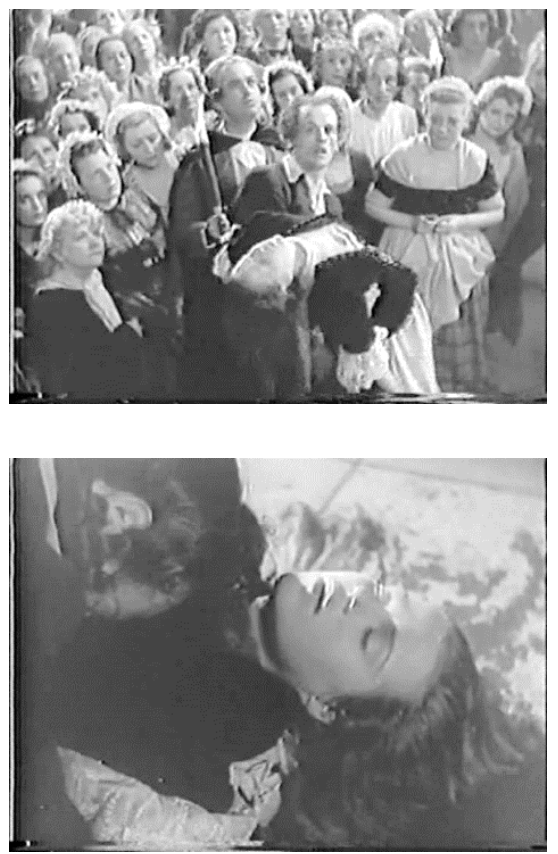

Figs. 1.14 e 1.15: Malte Jäger e Kristina Söderbaum da defunta não invocava apenas uma imagem da purificação de uma virgem sublimada pela morte. Pois a estética mediada pela técnica conformava a brancura do seu corpo no âmbito da ideologia. A técnica de iluminação produzia a ilusão de que de sua pele marmorizada emanava luz. A figuração da jovem morta reproduzia uma tradição de idealização da mulher branca, codificada visualmente pela submersão dela na luminosidade. O nacarado corpo sem vida, permanentemente infundido de claridade não apenas brilhava. Resplandecia. Emitia uma

163 SCHULTE-SASSE, Linda. Op. cit., 85.

164 SCHULTE-SASSE, Linda. Op. cit., 84, 89. 
transluscência radiante. O impenetrável alvor se espalhava, a partir dos restos mortais, para a cena numa convenção cinematográfica largamente estabelecida no período clássico. Ali, a mulher loura iluminava física e espiritualmente os homens ao seu redor ${ }^{165}$.

Uma complicada tecnologia de luz trabalhava para reforçar essa imagem exaltada da incorporeidade do feminino que, por essa via perversa, rebaixava a mulher ao status de Coisa. Uma cor sobredeterminada de implicações, sua realização na pele humana simplesmente inexiste, pois seu valor tonal é nulo. Ser absolutamente branco, observou Richard Dye, significa, por isso, não ser nada. $\mathrm{O}$ branco atesta o estado extremo da pura inexistência. Permite, assim, uma visão idealizada da transcendência. Sua negatividade denuncia a aspiração à dissolução da matéria no espírito, o qual, então, incide num sujeito sem nenhuma propriedade ${ }^{166}$. Branca, daí, é a cor da morte.

Na cerimônia em torno do cadáver da mulher morta, o sofrimento alcançou assim sua forma branca e, por extensão, perfeita. Abandonou a realidade das coisas transitórias e adentrou no território das memórias transcendentes. Ali, a dor se tornou eterna e, por isso, incontestável. Produzia, assim, uma imagem estética esmagadora e poderosa que provia a mágica justificativa doutrinária para todo tipo de violência reparadora contra o agressor, do pogrom ao genocídio.

165 DYE, Richard. White. Londres e Nova York: Routledge, 2002, 122-3.

166 DYE, Richard. Op. cit., 78, 80, 140. 


\section{Capítulo 2}

O grande amor

Die große Liebe (1942)

A despeito das leis que, desde 1933, proscreveram comentários maledicentes contra o regime e o Führer, anedotas que os tomavam como tema circularam desde a chegada do nazismo ao poder. Embora se manifestasse de forma velada, em círculos cada vez mais fechados, mesmo com o advento do Estado policial o humor resistiu à doutrina ${ }^{1}$. De modo que o SD (Sicherheitsdienst, "Serviço de Segurança") notificou uma piada que se tornou muito popular em 1942. Dava conta que um sujeito perguntava a outro:

-Você sabia que Zarah Leander foi convocada para comparecer imediatamente no quartel general de Hitler?

- É mesmo? Por quê?

- Para ela cantar "Eu sei que uma vez um milagre vai acontecer" 2 .

A sátira parecia especialmente engraçada aos alemães devido à reconhecida indisposição de Hitler contra a atriz e cantora Zarah Leander, da qual o humor se apropriava para desqualificar o discernimento do Führer no momento em que sucumbia em ruínas o mito de sua infalibilidade 3 .

A canção Ich weiß, es wird einmal ein Wunder geschehen fora um dos grandes hits de Zarah Leander, uma das canções de Die große Liebe ("O grande amor", Rolf Hansen, 1942), o Staatauftragfilm (filme comissionado pelo Estado) mais bemsucedido do Terceiro Reich. A produção recebeu a honraria máxima do governo,

\footnotetext{
${ }^{1}$ HILLENBRAND, F.K.M. Underground Humour in Nazi Germany 1933-1945. Londres, Nova York: Routledge, 1995, XV-XVII.

2 ASCHEID, Antje. Hitler's Heroines: Stardom and Womanhood in Nazi Germany. Filadélfia: Temple University Press, 2003, 209 e Hillenbrand, F.K.M. Op. cit., 110.

${ }^{3}$ Entre os alemães, não se desconhecia a indisposição do governo nazista em relação a Zarah Leander. Mesmo estrelando filmes de imenso sucesso na Alemanha desde 1937 e avultando como a atriz mais popular do Terceiro Reich, Hitler jamais acedeu em lhe condecorar com a honraria "Ator do Estado", concedida a outras personalidades artísticas muito abaixo de sua envergadura pública. ASCHEID, Antje. Op. cit., 160 e KOEPNICK, Lutz. The Dark Mirror: German Cinema between Hitler and Hollywood. Berkeley, Los Angeles: University of California Press, 2002, 81.
} 
o Prädikat "Recomendado por seu valor político e artístico. Estreou em junho de 1942 no Ufa-Palast am Zoo, coincidindo com as primeiras semanas da violenta campanha de bombardeios em áreas civis pela RAF britânica. Dali até o final de 1944 fora visto por 27,8 milhões de espectadores. Tornou-se o quarto lançamento mais popular da UFA numa lista de 280 produções do estúdio e, incontestavelmente, o mais prestigiado pelo público durante o Terceiro Reich, devolvendo, por isso, a maior bilheteria da época, 8 milhões RM. O filme foi o último e maior triunfo de Zarah Leander, cantando melodias que se tornaram seus maiores sucessos na Alemanha: além de Ich weiß, es wird einmal ein Wunder geschehen, Mein Leben für die Liebe ("Minha vida pelo amor") e Davon geht die Welt nicht unter ("Disso o mundo não vai acabar) ${ }^{4}$. Die große Liebe continuou popular mesmo depois da guerra. Terminou acrescido de um prólogo justificando o contexto de sua realização e foi subtraído de duas cenas - a sequência dos vizinhos abrigados no porão durante o bombardeio de Berlim e o número musical para as tropas de ocupação em Paris - quando voltou a ser regularmente exibido pela televisão ao público alemão ${ }^{5}$.

A intriga, considerada convencional por seus comentaristas, oferecia situações passionais, separações, reencontros, rompimentos e despedidas causadas pela guerra numa geografia que atravessava os recantos mais românticos da Europa, incluindo Berlim, Paris e Roma. Sua publicidade prometia apenas um espetáculo para deixar as plateias femininas "contentes, confiantes e felizes" 6 . Apresentava, porém, a tempestuosa história de amor de um piloto de

\footnotetext{
${ }^{4}$ Dentre as fontes consultadas, apenas Mary Elisabeth O'Brien apresentou números ligeiramente diferentes: estimou para o filme uma audiência de 27,2 milhões de espectadores e 9,2 milhões RM de bilheteria. ASCHEID, Antje. Op. cit., 194, COURTADE, Francis; CADAR, Pierre. Histoire du Cinéma Nazi. Paris: Eric Losfield, 1972, 240, KREIMEIER, Klaus. The Ufa Story: a History of Germany Greatest Film Corporation, 1918-1945. Tradução: Robert Kimbler, Rita Kimbler. Berkeley, Los Angeles: University of California Press, 1999, 299, O’BRIEN, Mary Elizabeth. Nazi Cinema as Enchantment: the Politics of Entertainment in the Third Reich. Rochester, Nova York: Camden House, 2004, 134-5, 154 e TEGEL, Susan. Nazis and the Cinema. Londres: Hambledon Continuun, 2007, 179.

${ }^{5}$ COURTADE, Francis; CADAR, Pierre. Op. cit., 241, LEISER, Erwin. Nazi Cinema. Tradução: Gertrud Mander e David Wilson. Nova York: Collier Books, 1975, 64 e ROMANI, Cinzia. Tainted Goddesses: Female Film Stars of the Third Reich. Tradução: Robert Connolly. Roma: La Moderna, $2001,82$.

${ }^{6}$ COURTADE, Francis; CADAR, Pierre. Op. cit., 240.
} 
Stukas (aviões de bombardeio da Lutfwaffe), Paul Wendlandt (Viktor Staal) e uma estrela do teatro de revista, Hanna Holberg (Zarah Leander), a qual era disputada também por outros admiradores, entre eles o maestro Alexander Rudnitzky (Paul Hörbinger) e o acróbata Alfred (Hans Schwarz Jr.). Mais desinibido do que seus concorrentes, Wendlandt atraiu o interesse de Hanna. Numa Berlim castigada pelos bombardeios aliados, ambos se renderam a uma noite de amor, a partir da qual se apaixonaram perdidamente. O romance, não obstante, parecia condenado por desencontros, equívocos e reconciliações sempre provisórias. Progredia intermitentemente mediante cartas e telegramas. Evolveu entre dois momentosos acontecimentos militares - a campanha na África e o início da invasão à Rússia - sem propiciar nenhuma felicidade duradoura aos amantes. Hanna se ressentia que o piloto colocasse os deveres militares à frente dela, o que a tornava depressiva e temperamental. Wendlandt se enfurecia que a cantora não se ajustasse ao seu papel de noiva de um soldado, resignando-se a uma existência de renúncias e esperas, mas recompensada com fugazes momentos de realização amorosa entre uma e outra missão militar. Ao contrário de sua camareira, Käthe (Grethe Weiser), que realisticamente assumiu o status de esposa de guerra, Hanna lamentava viver distante do objeto de sua adoração e se desesperava entre o narcisismo e a morbidez.

Paul, de fato, desposara a guerra. Dividido entre seu amor por Hanna e sua irredutível paixão pela farda, terminou gravemente ferido em ação. Informada do acidente, a cantora renunciou aos palcos para permanecer ao seu lado. Encontrou Paul, convalescendo num hospital militar. Ali, os amantes renovaram seus votos de fidelidade. Contemplaram seu futuro em comum na paradigmática imagem de um horizonte repleto de esquadrões de Stukas atravessando o céu rumo aos grandes combates.

Die große Liebe chegou ao público num momento em que a maioria dos longas-metragens dramáticos recuavam idealisticamente ao passado distante e heróico da Alemanha ou emolduravam locais contemporâneos amenos, distantes 
da guerra. Trazia à cena um retrato da vida cotidiana sob os rigores reais da situação do conflito: os relacionamentos interrompidos, os bombardeios aéreos, o racionamento de bens de consumo, os deveres dos civis com a causa nacional, as frustrações das pessoas comuns frente aos grandes acontecimentos e os sentimentos de abandono e solidão. Provia às plateias uma oportunidade de se identificarem empaticamente com personagens que experienciavam esforços semelhantes aos seus para equilibrarem suas expectativas privadas com as exigências do conflito ${ }^{7}$. Pertencia a uma modalidade de filmes de propaganda política que atualizavam ao contexto da guerra o tema da renúncia de uma mulher à sua carreira profissional para uma nova existência dedicada ao casamento e ao âmbito doméstico ${ }^{8}$. Tais realizações implicavam, daí, na estabilização do espaço feminino em papéis sociais adequados ao esforço militar. Formaram, por tudo isso, um padrão excêntrico de produções. Obras como Wunschkonzert ("Pedido de concerto", Eduard von Borsody, 1940), Aufwiedersehen, Franziska (Adeus, Francisca!, Helmut Käutner, 1941) e Die große Liebe contaram entre as poucas realizações que levaram a frente doméstica ao primeiro plano da cena. Proviam aos anseios relativos à guerra uma modulação voltada às mulheres, sobretudo pela caracterização de fortes personagens femininas. Evolviam, porém, em torno de combatentes divididos entre os deveres no front e seus relacionamentos pessoais. Pelo que as tramas principiavam com uma aventura amorosa do militar em licença, seguida de complicações românticas as quais reforçavam os laços de afeição entre a população civil e os soldados. Por conseguinte, seu apelo era duplamente enviesado. Aos soldados, convidavam resistir às tentações, demonstrando sua hombridade ao rejeitar os sentimentos que os desviassem da caserna, do patriotismo e do heroísmo. À audiência feminina oferecia como modelo de

\footnotetext{
${ }^{7}$ O'BRIEN, Mary Elizabeth. Op. cit., 135-6.

${ }^{8}$ O problema profissional da mulher, por seu lado, recebeu atençao em prestigiosas produções: Die vier Gesellen ("As quatro companheiras", Carl Froelich, 1938), Frau am Steuer ("Mulher no comando", Paul Marin, 1939) e Aufwiedersehen, Franziska (Adeus, Francisca!, Helmut Käutner, 1941), dentre muitas. Nesses muitos filmes, elas usualmente eram jornalistas, escultoras, escritoras, estilistas, pianistas. Ocupavam-se desses ofícios porque lhes importava o prazer, não a labuta. Vendedoras, operárias, cabeleiras, verdureiras, por exemplo, raramente vinham ao primeiro plano da tela. ASCHEID, Antje. Op. cit., 143-50 e ROMANI, Cinzia. Op. cit., 21-2.
} 
conduta a mulher que superou seu individualismo para suportar o esforço de guerra com desprendimento, sustentando a unidade familiar e incentivando os homens a cumprirem seu dever com o país9.

Tais filmes ofereciam um retrato de seu tempo e de uma experiência coletiva. Atualizavam problemas contemporâneos: a preservação da família, a natalidade, as ocupações voltadas ao esforço de guerra, as despedidas, as separações, os racionamentos e os bombardeios. Promoviam um arranjo que combinava retratos da grandiosidade das batalhas com histórias de pessoas comuns afetadas pelos acontecimentos militares. Formalizavam uma conexão imaginária pela qual a vitória militar da Alemanha seria também uma vitória pessoal de cada alemão. Atestavam que os sacrifícios, as renuncias e as perdas pessoais eram a garantia de um futuro mais próspero ${ }^{10}$.

Nessas produções havia, portanto, uma dupla face, masculina e feminina, arranjada num mosaico de formas que alinhavava o filme de guerra ao melodrama romântico, cambiando, entre um e outro, elementos estéticos dos cinejornais, dos documentários militares e da revista musical. Por enfatizar alternativamente um ou outro aspecto, contudo, as análises em torno de Die große Liebe produziram interpetações historiográficas divergentes e, por vezes, contraditórias, em geral niveladas em torno dos anseios da personagem feminina, dedicando, por extensão, poucas linhas à posição do protagonista masculino na trama. Tornou-se um caso emblemático em que até mesmo o gênero ao qual a obra se filiava não pode ser precisamente estabelecido pelos historiadores. Pois, ainda que contasse entre os poucos filmes ficcionais que tomavam como tema o dramático retrato da Alemanha contemporânea na conjuntura da guerra, David Stewart Hull situou a obra como um musical, embora atípico pelo seu tom "cinzento e pessimista"11. E porque, de fato, havia três números musicais, um deles ornamentado com um cenário de coristas

\footnotetext{
${ }^{9}$ FOX, Jo. Filming Women in the Third Reich. Oxford: Berg, 2000, 76-7, 79, 85-7, 99-100 e O'BRIEN, Mary Elizabeth. Op. cit., 119, 135.

${ }^{10}$ FOX, Jo. Op. cit., 76, 85 e O'BRIEN, Mary Elizabeth. Op. cit., 120.

${ }^{11}$ HULL, David Stewart. Film in the Third Reich: a Study of the German Cinema 1933-1945. Berkeley: University of California Press, 1969, 248-9.
} 
fantasiadas de flores, outros críticos acompanharam sem pestanejar esse juízo. Courtade e Cadars categorizaram o filme como um "drama sentimental mais que musical"12. Já Klaus Kreimeier qualificou Die große Liebe como "um filme educacional", atribuindo a Zarah Leander o mérito de o tranformar num fenômeno de bilheteria ${ }^{13}$. No que acompanhou Eric Rentschler, o qual relegou o elemento musical ao segundo plano e descreveu a obra como "uma moralidade pró-guerra disfarçada de woman's film", construído em torno de uma excitante noite de amor que evoluiu para um permanente coito interrompido ${ }^{14}$.

Ainda que todas essas interpretações encontrem respaldo nas formações sociais em que a obra tomou vulto, nenhuma delas atinou qual combinação de elementos fez do filme simultaneamente uma plataforma doutrinária e um articulador do desejo tão eficientes. Estudiosos e historiadores do cinema da época nazista reconheceram em Die Große Liebe um dos casos mais bemsucedidos de propaganda voltada ao público alemão e também efetiva nos territórios ocupados. Fixaram como elemento central da publicidade pró-fascista a óbvia mensagem de que a vitória final do país era mais importante do que a felicidade pessoal dos amantes ${ }^{15}$. Do que assentaram a ênfase das análises no despertar político de Hanna, pelo qual o filme produzia, de uma narcisista devotada ao exagero, uma cidadã libidinalmente reconciliada com as grandes causas nacionais ${ }^{16}$. Uma conclusão incontestável que, não obstante, deixa em aberto a contradição com a irrelevante importância até então atribuida pelo nazismo à educação política das mulheres. Uma vez no poder, os ideólogos fascistas não pouparam esforços para lhes esvaziarem a consciência pública, extirpando-as da cena política, pulverizando suas instituições e desmobilizando suas lideranças ${ }^{17}$. Qualquer que fossem suas entidades de representação, às

\footnotetext{
12 COURTADE, Francis; CADAR, Pierre. Op. cit., 1972, 240.

${ }^{13}$ KREIMEIER, Klaus. Op. cit., 298.

14 RENTSCHLER, Eric. The Ministry of Illusion: Nazi Cinema and its Afterlife. Cambridge: Harvard University Press, 2002, 140.

${ }^{15}$ O'BRIEN, Mary Elizabeth. Op. cit., 135 e WINKEL, Roel Vande, WELCH, David. Europe's New Hollywood? The German Film Industry under Nazi Rule, 1933-45 in WINKEL, Roel Vande, WELCH, David (eds.). Cinema and the Swastika: the International Expansion of the Third Reich Cinema. Hampshire: Palgrave Macmillan, 2011, 12.

16 ASCHEID, Antje. Op. cit., 198 e RENTSCHLER, Eric. Op. cit., 140.

$17 \mathrm{O}$ contingente feminino do Partido Nazista oscilou entre 5 a $10 \%$. Fora dos quadros partidários,
} 
mulheres não se dirimiu nenhum projeto sistemático de reforço na doutrina nacional-socialista. Muito ao contrário. A educação das jovens na BdM (Bund deutscher Mädel, "Liga das Moças Alemãs"), por exemplo, restringia-se a poucos tópicos, nenhum deles correlato à participação pública e ao esforço de guerra. Prevaleciam as atividades esportivas, os cursos de orientação em fé e beleza, além de alguma ocasional instrução em economia doméstica. E mesmo essas atividades eram mal organizadas e precariamente cumpridas por falta de lideranças competentes nesses temas ${ }^{18}$.

Por conseguinte, alternativamente, parte da crítica assinalou que a obra trazia uma deliberada mensagem de perseverança e otimismo concomitante ao declínio do entusiasmo popular com a guerra, a qual os alemães se deram conta, já não seria mais nem breve, nem branda ${ }^{19}$. Pois tal mensagem, vinha a propósito quando o filme entrou em produção, no outono de 1941, diante dos indícios de que segmentos amplos da população já haviam se fartado com o cotidiano estafante daquele conflito ${ }^{20}$.

Duas décadas atrás, a grande conflagração internacional havia oferecido a uma geração de rapazes a oportunidade de experimentarem o perigo e de afirmarem sua virilidade. “Em uma chuva de flores, saímos de casa, inebriados com a atmosfera de rosas e sangue", relembrou Ernst Junger ${ }^{21}$. Muito distante desse espírito de ebulição patriótica, a atualização da antiga beligerância

a existência política das mulheres era praticamente nula. O regime rapidamente votou à extinção a DFO (Deutscher Frauen Orden Rotes Haken Kreuz, "Ordem das Mulheres Alemãs da Vermelha Cruz Gamada"), a mais relevante liga de mulheres conservadoras e antifeministas. A poderosa NS-Frauenschaft ("Organização das Mulheres Nacional-Socialistas") foi relegada ao humilhante limbo das atividades políticas, exercendo funções decorativas em desfiles, paradas e comícios. E a BdM passou à tutela de líderes masculinos, subordinando-se à HJ (Hitlerjugend, "Juventude Hitlerista") EVANS, Richard J. The Coming of the Third Reich. Nova York: Penguin Books, 2003, 2830, 212-3 e MANN, Michael. Fascistas. Tradução: Clóvis Marques. Record, 2008, 202 e ROMANI, Cinzia. Op. cit., 19.

18 REESE, Dagmar. Growing Up Female in Nazi Germany. Tradução: William Templer. Michigan: University of Michigam Press, 2009, 22-5, 52, $73-7$.

${ }^{19}$ ASCHEID, Antje. Op. cit., 198 e FOX, Jo. Op. cit., 94.

${ }^{20}$ Registrando as impressões de recém emigrados da Alemanha, numa entrada de fevereiro de 1941 de seu diário, Brecht comparou a crescente indisposição dos alemães contra a guerra ao enfado do operário com a rotina de um trabalho fabril diário e sempre idêntico. Pois a guerra havia se tornado o que o nazismo sempre pretendera produzir: uma situação cotidiana, ainda que insuportável. BRECHT, Bertolt. Diario de trabajo I 1938/1941. Tradução: Hélida Mendilaharzu de Machain. Buenos Aires: Ediciones Nueva Visión, 1977, 246.

21 JUNGER, Ernst. Tempestades de aço. Tradução: Marcelo Backes. São Paulo: Cosac Naify, 2013, 7. 
continental ensejou outro tipo de emoção. Desde o princípio, observou Albert Speer, a população não investiu fervor algum na renovação da aventura militar. De tal modo que, em setembro de 1939, recordou-se, a atmosfera em Berlim era de ansiedade e temor pelo futuro ${ }^{22}$. Quando, ao meio-dia de 3 de setembro, por meio de um comunicado irradiado por alto-falantes na Wilhelmplatz, o regime informou que a Inglaterra havia declarado guerra contra a Alemanha, o correspondente da CBS William A. Shirer registrou em seu diário que as pessoas receberam a notícia com um misto de assombro e desalento ${ }^{23}$. Retrospectivamente, elas lhe pareceram petrificadas, incapazes de se reconciliarem com o fato de que Hitler as empurrara de novo para um conflito internacional24. De tal modo que, dessa vez, não houve, marchas triunfais, nem paredes decoradas com flores para saudarem as tropas. As ruas permaneceram vazias. Pela cidade, não se registrou excitação, nem comemorações, nem demonstrações de febre patriótica ou de histeria de massas ${ }^{25}$. E, na medida em que o conflito se arrastava, a guerra, na frente doméstica, passou a conotar bombardeios e privações e, na frente de batalha, o trauma da separação.

Die Große Liebe, sugeriram Antje Ascheid e Jo Fox, vinha, então, tratar desse trauma, acentuando o crucial papel da mulher na superação do difícil momento nacional. A retórica do valor do sacrifício, da postergação da felicidade privada, da importância do esforço de integração e da estabilização emocional dos soldados concernia às mulheres. A elas o filme atribuía a responsabilidade de administrarem todas as frustrações: as suas e também as dos homens ${ }^{26}$.

Nessa linha de análise, o filme prestava homenagem às mulheres no único domínio sobre o qual sua autossuficiência permanecia indiputável: o ambiente doméstico. Ali, reconhecidamente compunham uma poderosa formação social.

\footnotetext{
22 SPEER, Albert. Inside the Thrid Reich: Memoirs. Tradução: Richard Winston, Clara Winston. Nova York, 1981, 166.

${ }^{23}$ SHIRER, William A. Berlim Diary: the Journal of a Foreign Correspondent, 1934-1941. Baltimore: Johns Hopkins University Press, 2002, 200.

${ }^{24}$ SHIRER, William A. The Rise and Fall of the Third Reich: a History of Nazi Germany. Nova York: Simon\&Schuster, 2001, 615.

${ }^{25}$ SHIRER, William A. Berlim Diary: the Journal of a Foreign Correspondent, 1934-1941. Baltimore: Johns Hopkins University Press, 2002, 201 e SPEER, Albert. Op. cit., 167.

${ }^{26}$ ASCHEID, Antje. Op. cit., 199 e FOX, Jo. Op. cit., 96-7.
} 
Perfaziam um subterrâneo contingente de estabilização familiar e comunitária e, por isso, figuravam no centro de importantes políticas do regime, as quais obravam para as fixar nos papéis de esposas e mães. De tal modo que uma variedade de medidas legislativas operou tanto para lhes obstruir o acesso ao trabalho assalariado, quanto para impedir seu ingresso em universidades e no estudo secundário. Essa excisão da mão de obra e da atividade intelectual feminina não prospectava o aumento significativo de vagas no mercado e nas universidades para os homens, pois elas não competiam com eles pelos mesmos postos. O propósito das medidas era ostensivamente as consignar às funções domésticas ${ }^{27}$. O que escancarava, em diversos aspectos, a inconsistente relação da doutrina fascista com a realidade social na qual ela almejava incidir.

Durante os primeiros anos da regra nazista, a mulher fora idealisticamente alçada ao núcleo do programa biopolítico de engendramento da raça, pelo que o Estado tomava para si a tutela da vida numa política de policiamento social, de higienização e de eugenia. Por conseguinte, as primeiras leis expedidas pela nova ordem concerniam ao projeto de purificação genética e, por isso, implicavam direta ou indiretamente as mulheres: a Lei de Prevenção da Descendência Hereditária, de julho de 1933, a Lei para a Proteção da Saúde Hereditária do Povo e as Leis de Nuremberg de $1935^{28}$. Essas normativas coincidiam com as diretrizes de formação educacional da nova mulher fascista que investia no adestramento físico e psicológico das meninas para a produção de filhos. Doravante, a maternidade e a educação das crianças passavam a ser assuntos de uma racionalização técnica sistematizada pelo Estado ${ }^{29}$. O que firmou na função materna o papel essencial da mulher, sua função social e política mais prestigiada no Terceiro Reich, para a qual se promulgou uma data comemorativa, o Muttertag ("Dia das mães") e uma condecoração especial, a Mutterkreuz ("Cruz de mãe") ${ }^{30}$.

\footnotetext{
${ }^{27}$ EVANS, Richard J. The Third Reich in Power 1933-1939. Nova York: Penguin, 2005, 330, 332 e ROMANI, Cinzia. Op. cit., 19.

${ }^{28}$ AGAMBEN, Giorgio. Homo sacer: o poder soberano e a vida nua. Tradução: Henrique Burigo. Belo Horizonte: Editora UFMG, 2007, 154-6.

29 REESE, Dagmar. Op. cit., 42-4, 99-100.

${ }^{30} \mathrm{~A}$ medalha da Mutterkreuz vinha forjada em ferro para as mães de quatro filhos, em prata no caso de seis filhos e em ouro após o oitavo filho. ROMANI, Cinzia. Op. cit., 18.
} 
De modo que, com a eclosão do conflito militar, do ponto de vista doutrinário, a colaboração solicitada às mulheres para o esforço de guerra reincidiu nos seus papéis idealísticos de esposas e mães. Delas se exortava que demonstrassem heroísmo incentivando seus filhos e maridos a partirem ao combate e resistindo bravamente ao desespero. Ao lado da maternidade, o sacrifício desinteressado passou então a ser sua principal missão ${ }^{31}$.

Uma luminosa advertência de Adorno em sua Minima Moralia dava conta de que "aquela que se sente ferida quando sangra sabe mais de si do que aquela que se imagina flor porque isso apraz ao marido" 32 . Um conhecimento que desafia a redução do feminino aos estreitos programas das doutrinas autoritárias. O que justifica porque a imagem ideal de um feminino destituído de qualquer individualidade, neutralizado e desprovido de símbolos de afirmação sexual, reduzido a uma função biológica única (os trabalhos de reprodução de crianças do sexo masculino) existiu somente nas exortações dos ideólogos. Do princípio ao fim, o nazismo não conseguiu encarnar em nenhuma pessoa real sua imago da nova fêmea nórdica: saudável, natural e fértil ${ }^{33}$. Perscrutando em seus próprios escalões, o regime ofereceu o papel de primeira dama do Terceiro Reich a uma variedade de personalidades e todas se mostraram inaptas para a função. Magda Goebbels era cosmopolita e elegante demais, além de carregar a fama de arrogante, temperamental, irascível e inflexível. Não serviam também a espalhafatosa Emmy Göring, imbatível na arte da ostentação, nem a rústica Annelies von Ribbentrop, desprezada por sua falta de tato e suas péssimas maneiras. Estavam muito abaixo das idealizações do regime a insípida Margarete Himmler, a presunçosa Marie Auguste von Neurath e as indistintas Lina Heydrich e Sophie Funk ${ }^{34}$.

\footnotetext{
${ }^{31}$ EVANS, Richard J. The Third Reich at War: How the Nazis Led Germany from Conquest to Disaster. Nova York: Penguin, 2009, 360.

${ }^{32}$ ADORNO, Theodor W. Minima Moralia: reflexões a partir da vida lesada. Tradução: Gabriel Cohn. Rio de Janeiro: Beco do Azougue, 2008, 91.

${ }^{33}$ GUENTER, Irene. Nazi Chic? Fashioning Women in the Third Reich. Oxford: Berg, 2004, 99-105 e ROMANI, Cinzia. Op. cit., 20.

$34 \mathrm{E}$ se essas notáveis não pareciam remotamente úteis à política de frugalidade contra a frivolidade, além das margens do meio governamental, as opções eram ainda mais embaraçosas. Todas as possibilidades passíveis de publicidade implicavam em qualidades que contradiziam abertamente as solicitações de abnegação e submissão. Ainda que viesse ao público envergando
} 
Não apenas o regime carecia de modelos pedagógicos para orientar as moças alemãs nos caminhos da boa maternidade, mas também lhe faltava meios aptos a contê-los dentro do círculo fechado do casamento e da procriação. Os doutrinadores tiveram que assentir com o fato irrefutável de que a posição das mulheres na sociedade alemã, seu espaço no mercado de trabalho, o apoio ao regime e a adesão ao esforço de guerra ofereciam um quadro complexo que, em todas as instâncias, escapavam largamente às injunções do governo. De modo que, contra todas as diretrizes institucionais, o número de alemãs trabalhando em fábricas subiu de 4,2 milhões a 5,2 milhões entre 1933 e $1938^{35}$. A participação feminina no mercado de trabalho da Alemanha em 1939 já era mais elevada que na Inglaterra e nos Estados Unidos e assim permaneceu até o final da guerra. Em $1939,1 / 3$ das mulheres casadas entre 15 e 60 anos eram economicamente ativas. Compunham mais de $1 / 3$ da PEA nacional, ao passo que na Inglaterra essa parcela não passava de 1/4. Em 1940, perfaziam 40\% da mão-de-obra no Reich ${ }^{36}$. Nessa época, $34 \%$ da força de trabalho voltada para a guerra era composta por mulheres, uma parcela superior aos 25,4\% nos Estados Unidos e aos 33,1\% na Inglaterra. Em 1943, estimava-se que, da população feminina entre 16 e 45 anos, apenas 1,5 milhão delas ainda permanecia disponível à conscrição ${ }^{37}$.

$\mathrm{O}$ que significa que as mulheres na Alemanha nazista, longe de estarem relegadas ao limbo da idealização, eram uma força social determinante e

Dirndls (um típico vestuário folclórico) e uniformes corporativos, a diretora da NS-Frauenschaft, Gertrud Scholtz-Klink, era odiada até mesmo pelas suas subordinadas que a consideravam explosiva, mal-humorada e grosseira. Outra expoente do nazismo, a diretora cinematográfica Leni Riefenstahl, ambiciosa, segura de si e determinada, jamais renunciara ao seu halo de genialidade para descer ao chão dos homens que a circundavam. Beldades como a atriz de origem russa Olga Tschechowa e Lil Dagover, as estrelas cinematográficas favoritas de Hitler, eram frequentemente vistas nas cerimonias do regime, mas seu glamour e fama faziam delas paradigmas inadequados para incentivarem as mulheres a se contentarem em serem "naturais" e domésticas. GUENTER, Irene. Op. cit., 131-40.

35 ROMANI, Cinzia. Op. cit., 23.

${ }^{36}$ Essa discrepância pode ser compreendida pelas diferentes estruturas da mão-de-obra feminina alemã e anglo-americana. No Reich de 1939, o maior setor de trabalho feminino se sediava na agricultura que, nesse ano, empregava quase 6 milhões de mulheres. Na Inglaterra, ao contrário, das 6 milhões de trabalhadoras, menos de 10 mil estavam no campo. Tradicionalmente, o fardo do trabalho agrícola na Alemanha pesava desproporcionalmente sobre as mulheres, uma situação que se tornou ainda mais acentuada no período da guerra. TOOZE, Adam. The Wages of Destruction: the Making and the Breaking of the Nazi Economy. Nova York: Penguin, 2006, 358-9.

37 TOOZE, Adam. Op. cit., 515. 
relativamente autônoma. Sua importância transbordava do setor econômico, ultrapassava o âmbito político e se autodeterminava no nível das condutas sociais. A centralidade do feminino no Terceiro Reich não se decifrava, então, pela decodificação dos discursos misóginos emanados do regime. Na figura da mulher, o nazismo encetou um embate entre o desejo de autonomia e uma doutrina assujeitada ao parâmetro patriarcal. Diante do feminino, o regime encontrou um elemento de resistência, o qual, nem sempre capaz de superar, esmerou-se em contornar. Por conseguinte, quando decifrado na chave do desejo feminino um filme como Die große Liebe adquire nuances próprios pelos quais suas estruturas dramáticas se tornam menos conflitantes com seu contexto.

\section{$\underline{\text { Woman's film }}$}

Dentre seus comentaristas, Thomas Elsaesser veio a ser o único que alinhou Die große Liebe a uma tendência mais difusa de obras cinematográficas da época nazista pelo que o desejo da mulher não estava colocado em segundo plano, mas era reconhecido como tal ${ }^{38}$. Capturar o imaginário feminino para o alinhar à doutrina significava, então, levar em conta as aspirações e anseios das espectadoras nas salas de exibição. O que, sob o denominador psicanalítico, situa a obra num domínio vacilante e escorregadio. Pois a subjetividade feminina, na teoria psicanalítica, ocupou invariavelmente uma posição marginal. Seus modelos foram subprodutos da norma dada pela subjetivação masculina e, por isso, discutida nos termos da falta, da falha e da deficiência ${ }^{39}$.

\footnotetext{
${ }^{38}$ Das maiores bilheterias produzidas no Terceiro Reich - além de Die große Liebe, Wunschkonzert (26 milhões RM) e ... reitet für Deutschland ("... cavalga pela Alemanha, Arthur-Maria Rabenalt, 1941: 22 milhões RM) - apenas esse último não concernia aos diferentes papéis sociais da mulher contemporânea. Disso, Thomas Elsaesser sugeriu a predileção do público por filmes que tematizassem a realidade social das mulheres num registro coerente com seu contexto. Reconheceu essa tendência em uma variedade de realizações do mesmo período, notadamente os filmes dirigidos por Helmut Käutner: Aufwiedersehen Franziska, Romanze in Moll ("Romance em

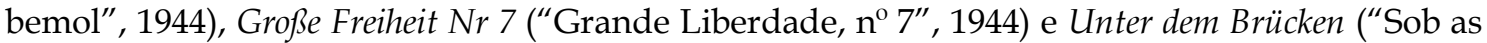
pontes", 1945). ELSAESSER, Thomas. Weimar Cinema and After: Germany's Historical Imaginary. Londres: Routledge, 2008, 412.

39 DOANE, Mary Ann. The Desire to Desire: the Woman's Film of the 1940's. Blooming: Indiana University Press, 1987, 21.
} 
Freud assentia que a psicanálise não dispunha do aparato necessário para oferecer alguma solução ao que ele definiu como o "enigma da feminilidade". A partir disso, elaborou uma tese que sediava o desejo feminino na Penisneid, a "inveja do pênis", e na maternidade, pelo que a posse de um bebê compensava a mulher da angústia por não dispor de um falo ${ }^{40}$. Do que Lacan, em consonância com Freud, reconheceu o falo como o significante mestre do processo de estruturação subjetiva, aduzinado, daí, que as mulheres não apenas têm sua subjetividade constituída em torno da inveja fálica, mas, além disso, da decepção pela sua própria castração ${ }^{41}$. Assim definidas a partir do ponto de vista masculino, a psicanálise ora as confinaria ao domínio da falha, ora as dispersaria no território do outro. Assim, a mulher se tornou, do ponto de vista da teoria psicanalítica, o protótipo do não-sujeito, consignada à condição de objetos de desejo ou de personificação de forças indomáveis ${ }^{42}$. Por conseguinte, a crítica feminista consistentemente denunciou também na grande categoria do cinema clássico voltado às mulheres e ao seu desejo, o woman's film, a reificação da mulher a partir da presunção da falta. De modo que, ali, ela não apenas não detinha um olhar próprio. Também sua subjetividade remanescia imperfeita e seu espaço se restringia ao campo alteritário e ao papel de objeto do desejo escópico ${ }^{43}$.

40 FREUD, Sigmund. Novas Conferências introdutórias sobre a Psicanálise: Feminilidade: Conferência XXXIII in FREUD, Sigmund. Obras psicológicas completas de Sigmund Freud Volume XXII. Tradução: José Luiz Meurer. Rio de Janeior Imago, 1996, 125-39.

41 Porque o que define o ser humano sexualmente é a presença ou a ausência do falo, Lacan decretou que $A$ mulher (com o artigo definido em letra maiúscula) não existe, pois ela não é inteira. Do mesmo modo, não há como se referir a alguma experiência pertinente a todas as mulheres, porque, insistiu Lacan, o todas as mulheres também não existe. "Não existe universal da mulher", asseverou. Na medida em que $a$ mulher não experimenta o trauma da castração, seu desejo não se confina ao gozo fálico. Situa-se, de acordo com a linha lacaniana, para além do falo, num campo mais próximo ao gozo dos místicos, cujo suporte é o grande A. Para considerações sobre o Grande A, cf. nota 45 da Introdução. LACAN, Jacques. O seminário livro 5: as formações do inconsciente. Tradução: Vera Ribeiro. Rio de Janeiro. Zahar, 1999, 285-7, LACAN, Jacques. O seminário, livro 6: o desejo e sua interpretação. Tradução: Claudia Berliner. Rio de Janeiro: Zahar, 2016, 134-5, LACAN, Jacques. Le seminaire Livre XX Encore 1972-1973. Paris: Éditions de Seuil, 1999, 14, 94-6, e LACAN, Jacques. Seminário, livro 18: de um discurso que não fosse semblante (1971). Tradução: Vera Ribeiro. Rio de Janeiro: Zahar, 2009, 64, 69-70.

${ }^{42}$ DOANE, Mary Ann. Op. cit., 10 e PRIBAM, E. Deidre (ed.). Female Spectactors: Looking At Film and Television. Londres e Nova York: Verso, 1988, 1.

${ }^{43}$ Steve Neale definiu o woman's film ("filme de mulher") como um gênero que enfatiza a situação de uma personagem feminina se esforçando para administrar problemas emocionais, sociais e psicológicos derivados especificamente de seu status de mulher. Molly Haskell (e com ela a crítica 
Privadas do significante fálico (e, portanto, da magia revelatória da castração que discerniria nela, a partir desse objeto perdido, o trajeto de sua construção como sujeito) e sem um objeto do desejo ao qual pudessem aspirar, às mulheres não restou outra coisa que o desejo de desejar. Por conseguinte, o woman's film apresentava à sua espectadora o seu desejo como algo passivo e, portanto, sujeito à posição masoquista, articulando uma experiência espectatorial voltada à comutação do sofrimento em prazer ${ }^{44}$. Nesses filmes, os sacrifícios, aflições, escolhas e lutas das protagonistas não se voltavam à sua emancipação, mas ao bem-estar de um homem amado ou dos filhos. As personagens, então, invariavelmente ganhavam os traços de vítimas. Frequentemente, encontravam destinos trágicos ou infelizes. Compunham uma imagem idealística pela qual o sofrimento se transformava em uma recompensa a qual somente as mulheres, pela sua condição biológica e psicossocial, podiam almejar ${ }^{45}$.

Na cena hollywoodiana, o woman's film, em suas estruturas fundamentais, preservava uma similaridade de temas e fórmulas repetidas obra após obra. Ainda assim, apontou Molly Haskell, estrelas de grande envergadura como Greta Garbo ou Joan Crawford, a partir das convenções dessa categoria, constituíram seus próprios gêneros ${ }^{46}$. Se, no cinema alemão, houve uma atriz à altura de Garbo, apta a se instituir como um gênero que, de um filme a outro, produzia invariavelmente uma mesma e singular representação do feminino, assimilável ao woman's flm, mas matizada com qualidades exclusivas, ela foi, sem

feminista anglo-americana), contudo, implicou esse "status de mulher" nos valores ideológicos burgueses e no sistema econômico que circunscreve a existência feminina no âmbito doméstico e na situação de dependência financeira. Para o que o woman's film passava a operar como um arranjo de discursos contabilizados numa elástica variedade de gêneros do cinema narrativo clássico e discriminados como "assuntos de mulheres": a vida doméstica, a unidade familiar, a educação dos filhos, os relacionamentos amorosos. Por extensão, o motivo centraldo woman's film envolvia o invariável tema do autossacrifício. Produzia, assim, uma mensagem paradoxal. Validava a condição de subserviência do matrimônio e da maternidade como tópicos autojustificados. Porém, reconhecia o quanto eram problemáticas essas opções, admitindo que a sociedade impunha às mulheres um fardo injustificável. DOANE, Mary Ann. Op. cit., 2-7, 34, HASKELL, Molly. From Reverence to Rape: the Treatment of Women in the Movies. Chicago: University of Chicago Press, 1987, 156-7 e NEALE, Steve. Genre and Hollywood. Londres e Nova York: Routledge, 2000, 189-91.

${ }^{44}$ DOANE, Mary Ann. Op. cit., 7, 12, 16.

${ }^{45}$ HASKELL, Molly. Op. cit., 161-4.

${ }^{46}$ HASKELL, Molly. Op. cit., 163. 
dúvida, Zarah Leander.

No contexto de sua súbita ascensão ao estrelato, de sua fixação como a primeira dama do cinema alemão durante o Terceiro Reich e pela peculiaridade dos seus talentos, uma variedade de críticos reconheceu em Leander uma personalidade complexa, contraditória e polivalente que transbordava para muito além das assunções ideológicas remendadas em torno de suas caracterizações.

Zarah Leander veio da Suécia às telas do Terceiro Reich para substituir um objeto original perdido, Marlene Dietrich. Uma diva dos palcos, celebrada como atriz e cantora em operetas de sucesso, Leander debutou no teatro em 1929. Após uma temporada de sucesso em Viena em 1936, atraiu a atenção dos caçadores de talento da UFA, os quais reconheceram nela qualidades adequadas para servir como um duplo de Dietrich e também um fac-símile de Greta Garbo. Estreou no cinema alemão com Premiere (Première, Géza von Bolváry, 1937), rodado na Áustria, representando uma estrela musical, um papel que viria a repetir em praticamente todos seus filmes subsequentes. Assinou um contrato exclusivo com a UFA que, daí em diante, cultivou-a como uma flor de estufa. Uma vigorosa campanha publicitária precedeu sua aparição na Alemanha, anunciando-a como uma criatura excepcional dissipando a impressão de que seu advento pretendia apenas preencher o vácuo de uma ausência. A promoção fez dela uma personalidade pública muito antes que a nova estrela se apresentasse diante das câmeras. Doravante, cada detalhe de suas aparições era cuidadosamente planejado. Seus close-ups requeriam horas de preparação para que, de seus traços fisionômicos, emergissem a máscara de inefável tristeza, sua marca registrada. Com ela protagonizou uma sucessão de hits: La Habanera (La Habanera, Detlef Sierk, 1937), Zu neuen Ufern (Recomeça a vida, Detlef Sierk, 1937), Heimat (Pecado de amor, Carl Froelich, 1938), Das Lied der Wüste ("A canção do deserto", Paul Marin, 1939), Es war eine rauschende Ballnacht (Noite de baile, Carl Froelich, 1939), Der Blaufuchs (A raposa azul, Viktor Tourjansky,1939) e Die groBe Liebe ${ }^{47}$.

\footnotetext{
47 Zarah Leander experimentou um estrelato esfuziante, porém fugaz. Seu último filme no Terceiro Reich, Damals ("Outrora", Rolf Hansen, 1943) não prosperou nas bilheterias, após o que abandonou a Alemanha nazista. No período do pós-guerra, lançou quarenta álbuns musicais,
} 
Descrita por seus contemporâneos como uma mundana cosmopolita e sofisticada, narcisicamente entretida com seu estrelato e avessa às questões políticas, a despeito de seu imenso prestígio, Leander se tornou uma personalidade mal enquadrada na ordem nacional-socialista 48 . Consequentemente, no pós-guerra, sua persona pública produziu uma variedade de leituras contraditórias pelas quais avultava ora como uma figura de resistência, ora como um dos ídolos malditos do nazismo. De sua presença exótica, suas mascaradas que desbancavam a imagem ideal da mulher nórdica, suas caracterizações carregadas de exagero e altamente estilizadas, uma linha de críticos vislumbrou nela um ícone transgressivo, resistente ao feminino "natural" cotejado pelo fascismo. Sua envergadura física e a voz de contralto confundiam os padrões de caracterização da típica heroína melodramática. Tais atributos pareciam ainda mais excêntricos nas narrativas repletas de excessos dos seus filmes ${ }^{49}$.

Detlef Sierk, diretor de dois dos seus grandes sucessos, reconheceu nela um apelo que pertencia a outra época. Atribuiu essa singularidade à sua máscara impenetrável para a qual a câmera atribuiu uma fisionomia de impassividade que viria, ao seu ver, representar uma original expressão da feminilidade

participou de seis filmes além de espetáculos musicais. Tornou-se uma contestada personalidade e, simultaneamente, um objeto de culto. A memória de seu sucesso no apogeu do nazismo, ensejou reações hostis aos seus filmes, mas ela encontrou uma calorosa saudação no seu retorno aos palcos, em turnês por Munique, Hamburgo, Berlim e Viena. Viria a ser particularmente apreciada pelo público homossexual, que fez dela um dos grandes ícones da subcultura gay europeia. ASCHEID, Antje. Op. cit., 2003, 155-8, 173, CARTER, Erica. Dietrich's Ghosts: the Sublime and the Beautiful in the Third Reich Film. Londres: British Film Institute (BFI), 2011, 157, 174-7, 1801, 186-7, COURTADE, Francis; CADAR, Pierre. Op. cit., 236-40, KOEPNICK, Lutz. Op. cit., 81, KREIMEIER, Klaus. Op. cit., 297, 299, 302, RENTSCHLER, Eric. Op. cit., 135 e e ROMANI, Cinzia. Op. cit., 72-4.

48 Goebbels recebia de bom grado os proventos de seu starpower, mas jamais cultivou relações cordiais com ela. Hitler abertamente desprezava suas performances. Tornou-se particularmente antipática aos doutrinadores porque manteve associações pessoais e profissionais com personalidades artísticas resilientes ao nazismo: o cantor Max Hansen, um parodiador de Hitler, o diretor Detlef Sierk e o letrista Bruno Balz, um dos expoentes no seu círculo de amigos homossexuais. De modo que em 1943, quando renunciou à sua carreira de primeira diva do cinema alemão, não houve consternação alguma por parte das autoridades do Reich. "Finalmente as mulheres alemãs podem respirar de novo", comentou apenas Himmler. ASCHEID, Antje. Op. cit., 160, GIESEN, Rolf. Nazi Propaganda Films: a History and Filmography. Jefferson: McFarland, 2003, 154 e RENTSCHLER, Eric. Op. cit., 128.

${ }^{49}$ KOEPNICK, Lutz. Op. cit., 78. 
nórdica $^{50}$. Do que Klaus Kreimeier identificou nela, então, não um fator de resistência, mas, ao contrário, um símbolo quintessencial do nazismo, uma personalidade que conferia lustro ao terror. Seus filmes, opinou Kreimeier, submergiam em enredos melodramáticos repletos de clichês e variações do kitsch num esforço concertado para encorajar as mulheres a tolerarem suas frustrações sem perder a compostura. Pois, na sua incomparável habilidade para exprimir melancolia, o regime teria encontrado o veículo ideal para expressar um romantismo exaltado, destinado ao gozo masoquista da sublimação ${ }^{51}$.

A estilização dos seus filmes se ajustava, decerto, a esse reincidente padrão das suas caracterizações. Suas personagens primeiramente se ofereciam como espetáculo visual, estimulando o desejo, apelando ao prazer pelo exagero. Em seguida eram desbancadas desse deleite para submergiam em castigos ignominiosos, oferecendo uma segunda saída de satisfação pelo excedente - o gozo do sofrimento ${ }^{52}$. Do que seus críticos sublinharam a falta de variedade de suas personagens: apesar da diversificação de máscaras e dos diferentes contextos, os filmes incidiam em temas constantes ${ }^{53}$. Todas as suas personagens filiaram Leander à estirpe das mulheres martirizadas pela paixão, cuja conduta, prevista num sistema de escoamento do desejo recalcado que jamais chegava a desestabilizar a ordem, podia simultaneamente parecer transgressiva e não desafiar o regime ${ }^{54}$. Estigmatizada assim como uma presença conformista, sobrecarregada de elementos artificiais para emular uma falsa rebelião erótica, imputaram-lhe a mácula da impostura, pelo que emprestava um glamour sintético e vazio às suas encenações do sofrimento e da renúncia femininas ${ }^{55}$.

A mais autêntica estrela cinematográfica do período fascista, considerou Cinzia Romani, parecia então ter firmado sua posição precisamente porque não era, de fato, uma "típica" mulher alemã: descomplicada, natural e gentil ${ }^{56}$. A

\footnotetext{
${ }^{50}$ KOEPNICK, Lutz. Op. cit., 82 e KREIMEIER, Klaus. Op. cit., 299.

${ }^{51}$ KREIMEIER, Klaus. Op. cit., 299-300.

${ }^{52}$ CARTER, Erica. Op. cit., 185.

${ }^{53}$ ASCHEID, Antje. Op. cit., 157.

${ }^{54}$ RENTSCHLER, Eric. Op. cit., 144.

${ }^{55}$ ASCHEID, Antje. Op. cit., 158.

${ }^{56}$ ROMANI, Cinzia. Op. cit., 27.
} 
partir do que, acedeu Lutz Koepnick, a imagem de Leander, provia um gritante contraste com as atrizes nativas, suprindo a audiência com uma poderosa figuração da mulher fatal estrangeira. Conjurada como um Doppelgänger de Dietrich, fazia a miragem ideal da mulher ariana encarnada por Kristina Söderbaum - atlética, sentimental, passiva e robusta - parecer tacanha e desinteressante. Essa femme fatale, rescendendo à Europa do fin de siècle, veio a Alemanha nazista como um memento do decadentismo continental em completo desacordo com a nova ordem, observou Eric Rentschler ${ }^{57}$. Daí, após a derrocada do Reich, o mito da diva popular, cujas performances extravagantes e carregadas de erotismo transportavam sua audiência feminina para os conhecimentos proscritos do amor, proveu um acréscimo de idealização tardia que esmaeceu os limites entre a personalidade da atriz e suas representações nos filmes ${ }^{58}$.

Porque sua presença, opinou Lutz Koepnick, firmava um compromisso entre os imperativos doutrinários e a mercantilização da cultura de massa para preencher um arco de experiências catárticas passíveis de serem prontamente empacotadas para consumo, às suas plateias, “a voz e a imagem de Leander significavam tudo e nada". E por haver servido como receptáculo de investimentos emocionais tão contraditórios, Koepnick se alinhou aos críticos que a rotularam como "a mulher mais falsa do século" 59. Do que, então, o trabalho analítico em torno de seus filmes se evadia das performances e recuava às idiossincrasias da personalidade da atriz, ou, mais precisamente, à sua contestável, posto que privilegiada, posição de máxima estrela cinematográfica nos anos de glória e terror do Reich ${ }^{60}$.

Lutz Koepnick enfatizou a peculiar e problemática ênfase autorreferencial nas caracterizações de Zarah Leander. Nos filmes, ela encarnou o invariável papel da grande diva, um actante que remetia a ela mesma, a meta-estrela transitando em cenários de luxo com mais grandeza e pompa do que suas

\footnotetext{
${ }^{57}$ KOEPNICK, Lutz. Op. cit., 81 e RENTSCHLER, Eric. Op. cit., 128.

58 RENTSCHLER, Eric. Op. cit., 129.

${ }^{59}$ KOEPNICK, Lutz. Op. cit., 86.

${ }^{60}$ ASCHEID, Antje. Op. cit., 158.
} 
contrapartes hollywoodianas ${ }^{61}$. Tal presença se adensava de um filme a outro, de modo que as personagens validavam a personalidade entrevista por trás da caracterização. A situação de uma estrela interpretando uma estrela em Die groBe Liebe renovava, por conseguinte, uma relação especular pela qual a performer e a personagem eram reiteradamente confundidas. $\mathrm{O}$ artificio desdobrava a função social da estrela cinematográfica como objeto do desejo e modelo de conduta. Essa arregimentação, contudo, invocava um sistema colateral de significações dificilmente contidas dentro de um único desígnio doutrinário. Era na imagem estelar de Leander que a estratégia da publicidade do regime buscava fixar sua mensagem. Essa, não obstante, arrastava junto com o material político, o conteúdo transgressivo implícito na própria condição do estrelato. Do que Die große Liebe se cindia, então, em torno da politização de uma figura social devotada ao prazer do público, ao exibicionismo, ao narcisismo e, portanto, muito pouco apta à desinteressada devoção patriótica. A partir dos laços de identificação que o público feminino comungava com a artista, a obra pretendia arregimentar a atenção e o interesse de suas espectadoras, renovando esse pacto para a situação contemporânea da guerra. Porém, porque essa estrela era Zarah Leander, a invocação da grande diva causava muitas e profundas rasuras à mensagem política.

Contrariando Adorno e Benjamin, para quem astros de cinema denunciavam não a presença de uma personalidade, mas, sim, de uma singularidade baseada na mesmice, uma linhagem de críticos viria reconhecer no estrelato um vínculo social conveniado entre o performer e sua audiência pelo que, na persona do ator, firmava-se um protótipo idealizado de comportamento ${ }^{62}$. Estrelas cinematográficas são, por isso, tanto uma criação da cultura quanto do desejo. Como tais, surgem e desaparecem num curto espaço de tempo,

\footnotetext{
${ }^{61}$ KOEPNICK, Lutz. Op. cit., 81.

62 ADORNO, Theodor W.: HORKHEIMER, Max. Indústria cultural: o Esclarecimento como mistificação das massas in ADORNO, Theodor W.; HORKHEIMER, Max. Dialética do Esclarecimento. Tradução: Guido Antonio de Almeida. Rio de Janeiro: Zahar, 1985, 105, 108-111, BENJAMIN, Walter. A obra de arte na época de sua reprodutibilidade técnica (segunda versão). Tradução: Francisco De Ambrosis Pinheiro Machado. Porto Alegre: Zouk, 2014, 66-9 e SCHICKEL, Richard. The Stars. Nova York: Bonanza Books, 1962, 10, 12.
} 
respondendo a repentinas demandas psicossociais ${ }^{63}$.

Estrelas de cinema coadunam-se ao campo do desejo em três níveis: na repetição, no gozo e na imagem hipertrofiada. De estrelas se solicita, primeiramente, que sejam elas próprias, e, portanto, nas margens da performance, devem aparentar sempre o mesmo. Suas personagens são delineadas por uma lei da repetição daquilo que as consagrou numa performance passada. A forma de seu trabalho chega então ao público pré-condicionada pelas encenações que a precederam ${ }^{64}$. De modo que carregam para dentro do filme o código do jogo, demarcando o campo da identificação e, assim, orientando a direção do desejo ${ }^{65}$. Cumprem, desse modo, uma função afirmativa naquilo que Lacan designou como uma Rück-Phantasie, uma fantasia reversa66. Referem-se, portanto, a uma experiência retrospectiva pelo que o fã adquire domínio nos gestos e comportamentos do grande astro.

A estrela transita no território do desejo também porque se permitiu experimentar o tabu do gozo e assim ela vive além do proibido. "A estrela goza pelo universo inteiro", ilustrou Edgar Morin. "Ela tem a grandeza da prostituta sagrada"67. Por isso, inspira uma modalidade de amor fusional que escapa à apropriação. Muito ao contrário, quanto mais partilhado, mais esse amor se valoriza. Ele desperta fantasias eróticas, mas tal paixão se manifesta pela adoração ao invés da posse, um sentimento que subsidia um culto ao astro o qual evolve em manifestações de transe histérico na presença do ídolo ${ }^{68}$.

Porquanto um astro de cinema precede, determina e transcende seu personagem, sua presença implica numa coparticipação pela qual intérprete e personagem formam um híbrido. Ele não experimenta a dialética da representação que atormenta a relação entre um ator e seu personagem ${ }^{69}$. Ambos

\footnotetext{
${ }^{63}$ SCHICKEL, Richard. Op. cit., 12.

${ }^{64}$ MORIN, Edgar. Les stars. Paris: Éditions du Seuil, 1972, 122 e SCHICKEL, Richard. Op. cit., 15.

65 SORLIN, Pierre. Sociologie du cinema: Ouverture pour l'histoire de demain. Paris: $6^{\circ}$ Aubier Montaigne, 1977, 136.

${ }^{66}$ LACAN, Jacques. O seminário Livro 6: o desejo e sua interpretação. Tradução: Claudia Berliner. Rio de Janeiro: Zahar, 2016, 475.

${ }^{67}$ MORIN, Edgar. Op. cit., 62.

${ }^{68}$ MORIN, Edgar. Op. cit., 68, 87.

69 GOMES, Paulo Emílio Salles. A personagem cinematográfica in CÂNDIDO, Antonio, ROSENFELD, Anatol, PRADO, Décio de Almeida, GOMES, Paulo Emílio Salles. A personagem de
} 
coabitam no seu corpo que, uma vez inscrito na tela, transfigura-se e, ali, permanece imperecível, imutável, protegido da usura do tempo ${ }^{70}$. Sua corporalidade imaterial sugere a decantada a ilusão sadeana da criatura que contém um corpo indestrutível dentro de seu corpo transitório, isento das aflições do tempo, sustentado e garantido por uma ordem simbólica superior ${ }^{71}$. Por conseguinte, estrelas não representam a si mesmas, mas a imagem de si, um aspecto de sua personalidade transformado em totalidade ${ }^{72}$. Hipererotizada, imortalizada, transbordando excesso, as estrelas se apresentam como a imagem depurada e hipertrofiada de um ser humano, um resíduo altamente estilizado e hipérbolico da pessoa ${ }^{73}$. Nessa condição de resto imageticamente integrado que demarca um excedente, sustentando uma relação do sujeito com o que ele não é para orientar a direção do olhar, e, assim, responder formalmente à lógica do desejo, uma estrela de cinema constitui a própria definição do objeto fundamental da fantasia, o petit objet $a^{74}$.

$\mathrm{Na}$ Alemanha, esse pequeno objeto a ganhou contornos muito específicos, diferindo substancialmente de sua contraparte hollywoodiana ${ }^{75}$. Ali, os laços culturais do público com seus atores constituíam um fator crucial na fixação de

fição. São Paulo: Perspectiva, 2011, 114-5, MORIN, Edgar. Op. cit., 36-7 e SORLIN, Pierre. Op. cit., 135.

${ }^{70}$ LIPOVETSKY, Gilles: SERROY, Jean. A estetização do mundo: Viver na era do capitalismo artista. Tradução: Eduardo Brandão. São Paulo: Companhia das Letras, 2015, 207-8.

71 ŽIŽEK, Slavoj. The Sublime Object of Ideology. Londres, Nova York: Verso, 2008, 13.

72 SCHICKEL, Richard. Op. cit., 14-5.

${ }^{73}$ LIPOVETSKY, Gilles: SERROY, Jean. Op. cit., 208.

${ }^{74}$ Para observações adicionais acerca do pequeno objeto $a$, cf. nota 46 na Introdução. LACAN, Jacques. O seminário Livro 6: o desejo e sua interpretação. Tradução: Claudia Berliner. Rio de Janeiro: Zahar, 2016, 334, 374 e LACAN, Jacques. O seminário Livro 10: a angústia. Tradução: Vera Ribeiro. Rio de Janeiro: Zahar, 2005, 50 e ŽIŽEK, Slavoj. Looking Awry: an Introduction to Jacques Lacan through Popular Culture. Cambridge e Massachusetts: October Book/ Massachusetts Institute of Technology, 1991, 12.

${ }^{75}$ A relação de empatia entre o público alemão e um performer dependia dos discursos fixados em torno de sua atividade como artista e personalidade pública: as atividades profissionais, o background teatral, os papéis favoritos e os próximos projetos. Divórcios, romances e escândalos não faziam, por conseguinte, parte do cardápio das revistas de cinema. Atores cinematográficos populares eram, por isso, nomeados nas revistas como Filmlieblinge, favoritos da tela. Rejeitavam firmemente a denominação Filmstern, estrela de cinema, para se distanciarem da noção da film star norte-americana, associada ao sensacionalismo, ao talento mediano e à frenética ambição pela popularidade. GARNICARZ, Joseph. The Star System in Weimar Cinema in ROGOWSKI, Christian (ed.) The Many Faces of Weimar Cinema: Recovering Germany's Filmic Legacy. Rochester, Nova York: Camdem House, 2010, 123-7. 
um estrelato. Os performers favoritos, mesmo aqueles que não procediam do país, desenvolveram suas carreiras em filmes nacionais, falados na língua alemã, fortalecendo e prestigiando a indústria cinematográfica nativa ${ }^{76}$. Daí, o advento do cinema sonoro, antecedendo em poucos anos a ascensão do nazismo, abriu a cena para novas personalidades como Renate Müller, Lilian Harvey, Sybille Schmitz, Ilse Werner e Marianne Hoppe ao mesmo tempo que preservou seus favoritos de Weimar - Emil Jannings, Werner Krauß, Heinrich George, Hans Albers, Willi Forst, Heinz Rühmann, Luise Ulrich e Magda Schneider - além de atrair a si talentos continentais como Käthe von Nagy, Marika Rökk, Lida Baarova e Kristina Söderbaum ${ }^{77}$. Em meio ao que, Zarah Leander viria a constituir sua intrigante categoria à parte. Seu domínio da língua alemã era considerado precário mesmo pela crítica sujeitada ao RMVP78. Não realizou nenhum filme na vilipendiada República de Weimar, mas desembarcou no Reich para, paradoxalmente, preencher o vazio da última diva weimariana, Dietrich. Porque revigorava o lustro do decadentismo republicano ao invés de reforçar os determinantes da nova ordem, sua imagem pública necessitava de persistentes retoques $^{79}$. Em contraste com as musas do cinema alemão, sob a República e sob

\footnotetext{
${ }^{76}$ GARNICARZ, Joseph. Op. cit., 127.

77 ELSAESSER, Thomas. Op. cit., 387-8, 389, 404.

${ }^{78}$ A inabilidade de Leander em falar alemão limpidamente acentuou uma qualidade de exotismo estrangeiro e a distanciou das demais atrizes europeias que labutavam para se adequar à tipologia da Fraulein teutônica. Dominou, por isso, quase sozinha o cenário do cosmopolitismo internacional. Representou uma sueca em La Habanera, uma húngara em Der blaufuchs, uma falsa norte-americana em Heimat, uma exploradora no Saara em Das Lied der Wüste e uma médica sueca refugiada na América Latina em Damals em caracterizações que permitiam à sua plateia uma evasão imaginária a paisagens remotas contra a rigidez cotidiana do Terceiro Reich. ROMANI, Cinzia. Op. cit., 74.

${ }^{79}$ Nenhuma estrela conseguiu, de fato, oferecer a imagem integral de uma Kriemhild platinada. Luise Ulrich, Ilse Werner e Marianne Hoppe podiam transitar pelos clichés da jovem donzela ao da dócil esposa e, daí, ao da mãe redentora, mas apenas se tornavam atraentes quando aderiam ao mundanismo, à sensualidade e à elegância, territórios dominados pelas atrizes imigrantes: a húngara Marika Rökk, a polonesa Pola Negri, a britânica Lilian Harvey e notadamente Zarah Leander. Pela sua condição de estrangeiras, essas atrizes frequentemente recebiam papéis que acentuavam suas qualidades eróticas, as quais não convinham às atrizes alemãs. E mesmo com essa ressalva, uma evidência adicional da inconsistência doutrinária do nazismo era que, enquanto os seus ideólogos enfatizavam a culminância da emancipação feminina nos três "K"s Küche, Kirche, Kinder ("cozinha, igreja, crianças"), a maioria dos woman's films aprovados por Goebbels evadiam-se do ambiente doméstico e abundavam em sofisticação e cosmopolitismo. ASCHEID, Antje. Op. cit., 158-9, KREIMEIER, Klaus. Op. cit., 297, KOEPNICK, Lutz. Op. cit., 74 e RENTSCHLER, Eric. Op. cit., 126, 143.
} 
o Reich, Zarah Leader nem de longe atravessava a cena como uma magnífica sonâmbula que, transfixada num estado catatônico, permitia-se a qualquer fantasia erótica emoldurada pela sublimação. Muito ao contrário, interpretava somente profissionais de sucesso, mulheres solteiras e independentes, criaturas de luxo e artificialidade ${ }^{80}$. Oferecia uma exterioridade estável à tensão irredutível do desejo contra o dever e, assim, rescendia não ao programa fascista, mas à miragem daquela figura social rotulada como a "nova mulher", uma quimera que, desde meados do século XIX, servia a todo tipo de elucubração ideológica ${ }^{81}$. O que a distanciava ainda mais do contexto facista para a situar firmemente no maldito imaginário weimariano.

Assim, Rentschler identificou em Leander uma figura de extremos. Reconheceu que sua persona dramática contradizia fortemente a fixação do feminino nos índices da passividade, da endogamia racial e da maternidade. Seu magnetismo cinematográfico rejeitava as construções preconizadas pela doutrina para investir numa identidade voltada ao exagero. Do que franqueava à sua audiência um conhecimento sobre a sexualidade muito distante do ideal burguês da donzela submissa, natural e espôntanea. Sua figura comportava, portanto, transformações extremas nos penteados e figurinos, numa persistente experimentação de semblantes. Rentschler identificou nessas mutações estéticas

\footnotetext{
${ }^{80}$ ASCHEID, Antje. Op. cit., 171.

81 Pois os filmes da época weimariana respondiam ao advento de uma cultura de consumo voltada à celebração da aparência com a fantasia intitulada "a nova mulher". O problema entre essência e aparência, entre profundida e superfície, entre gênero e identidade fora uma preocupação singularmente transladado nesse cinema em torno da figura feminina e de sua sexualidade. Por esse meio, os filmes davam continuidade a uma tradição que fixava o feminino no campo da alteridade para nela rebater as dúvidas e anseios masculinos. Na imagem da "nova mulher", observou Andreas Huyssen, foi assim formalizada uma alegorização da cultura de massa que constituía o obverso da modernidade. Enquanto ao modernismo se atribuiu a estampa da virilidade criativa, a cultura de massa se voltava à perpétua busca de satisfação às demandas do desejo: uma dicotomia pela qual a modernidade parecia progressiva, dinâmica e masculina, enquanto a cultura de massa se mostrava monolítica, indiferenciada, absorvente, regressiva e totalitária. De modo que essa mulher-imagem do cinema weimariano serviu como o padrão de valor na base de uma economia simbólica pela qual todas as demais relações - identidade, gênero, modernidade, cultura - podiam ser mensurados. Constiuiu, assim, um receptáculo da concupiscência coletivamente recalcada que, nos filmes, oferecia um fulminante vislumbre das possibilidades eróticas perdidas. Tornou-se o actante pelo qual o cinema podia formalizar as construções sociais que ora definiam, ora desconstituíam as linhas cada vez mais reversíveis do masculino e do feminino. ELSAESSER, Thomas. Op. cit., 260-1, 266, 289 e HUYSSEN, Andreas. After the Great Divide: Modernism, Mass Culture, Postmodernism. Bloomington, Indiana: University of Indiana Press, 1986, 44-7, 55, 57
} 
uma senha para satisfação do desejo de trocar provisoriamente de identidade e adentrar numa vida dupla, pelo que a atriz se tornou um indesejável modelo de comportamento para as mulheres do Terceiro Reich ${ }^{82}$.

A imagem de Leander passou então a conotar um valor de duplicidade, que se tornou sua marca como estrela de cinema. O público encontrou nela uma personalidade desdobrada em duas, na qual a repressão fascista ao feminino e as fantasias eróticas dos espectadores tensionavam uma à outra de uma maneira problemática aos olhos dos censores ${ }^{83}$. Um traço, ademais, vigorosamente enfatizado pela sua aparência. A despeito de sua fotogenia, pelo que por Courtade e Cadars a qualificaram como "a mulher mais bonita do cinema hitlerista", Zarah Leander estava longe do ideal de beleza "natural" promovido pelos nazistas ${ }^{84}$. Sua fisionomia enigmática sugeria a qualidade transcendente do eterno feminino que a descolou de suas referências originárias (Garbo e Dietrich). Mas a estatuesca envergadura e a voz potente lhe proviam uma qualidade masculina, o que produziu uma personalidade cinematográfica singular, cujo atributo fundamental era a junção de contrários: ternura e resistência, contemplação e expressividade, doçura e mundanismo, espiritualidade e sensualismo, sadismo e masoquismo, paixão autêntica e frívola ironia. Seu apelo, acrescentou Lutz Koepnick, incidia, então, na capacidade de superar oposições uma compleição opulenta e um rosto angelical, uma expressividade que passava da euforia ao sofrimento, um carisma ao mesmo tempo ordinário e repleto de cosmopolitismo, sensualidade e espiritualidade, uma máscara erótica para encobrir sua afetividade maternal, uma mistura de determinação e renúncia, egocentrismo e masoquismo, autonomia e dependência, artificio e espontaneidade. Transitando numa zona de imprecisão, Leander trazia, então, tudo de uma vez ${ }^{85}$.

Sua figura era resultado de uma bricolagem de elementos discrepantes e o prazer de sua presença consistia em acompanhar os sucessivos

\footnotetext{
82 RENTSCHLER, Eric. Op. cit., 128. 143.

83 ASCHEID, Antje. Op. cit., 162.

84 COURTADE, Francis; CADAR, Pierre. Op. cit., 237

85 KOEPNICK, Lutz. Op. cit., 80 e RENTSCHLER, Eric. Op. cit., 138.
} 
desmascaramentos das personagens. Comportando múltiplos significantes, a imagem polimórfica de Leander trafegava em direções variadas, da transgressão à conformidade ${ }^{86}$. Assumia, por isso, a própria qualidade de pequeno objeto $a$ na sua forma polivalente, um significante vazio, veiculado numa imagem multifacetada regida pela fantasia, flutuando indistintamente entre a subversão e a resignação. Os índices do objeto $a$ - o excesso reduzido à moldura de uma forma reincidente e hiperbólica que regulamenta a economia do gozo, orientando o desejo, estendendo-lhe a satisfação numa fantasia que invariavelmente retornava ao mesmo ponto - estão perfeitamente inscritos nas cararterizações de Leander. Poderiam, aliás, referirem-se a ela ou a qualquer outra atriz cinematográfica de sua estatura no seu tempo e em qualquer contexto, fascista ou liberal. Suas formas, portanto, resistem às leituras polarizadas que trabalham para a situar em algum lado da linha ideológica na qual se apartam conformidade e resistência ${ }^{87}$. Zarah Leander habitava simultaneamente os dois campos. Se tornou, por isso, um problemático articulador de fantasias pelas quais desejos que resistiam à totalização encontravam uma Gestalt em que podiam ser modulados e, assim, retornarem sublimados à experiência cotidiana.

O advento de Leander à cena da cultura de massa, portanto, envolvia solicitações e promovia satisfações que escapavam à capacidade de controle dos meios de supervisão social. Filme após filme, o departamento de publicidade da UFA necessitava contornar os obstáculos impostos pelos censores para a oferecer como uma mulher cosmopolita, elegante, sensual e autossuficiente quando tudo isso era justamente o que os ideólogos do regime almejavam erradicar. O material promocional que acompanhava os lançamentos transformava-se, então, num discurso paratextual destinado a contrabalançar o excedente de transgressões embaladas na produção. Transbordava em menções à sua prontidão para o

\footnotetext{
${ }^{86}$ KOEPNICK, Lutz. Op. cit., 76.

${ }^{87}$ Antje Ascheid aduziu que o apelo de Leander era definido no nível da ambivalência, solicitando provocações eróticas e as exteriorizando no registro da melancolia, o que fazia seu conteúdo contraditório parecer politicamente inócuo. As ambiguidades das mensagens não fixavam um discurso subversivo, mas também não se firmavam como pura propaganda. Ofereciam, para além de uma posição estática como elemento de promoção ou contestação do regime, uma multiplicidade de interpretações, incluindo contra-leituras dependentes ora da sensibilidade de seus admiradores, ora da animosidade de seus detratores. ASCHEID, Antje. Op. cit., 159, 211.
} 
trabalho, sua camaradagem com os colegas no estúdio, sua simplicidade, suas participações em eventos beneficentes, sua proficiência como uma artista de múltiplas capacidades, uma diva dos palcos $e$ também uma afetuosa esposa e uma mãe zelosa (a despeito de ser divorciada e ter deixado os filhos na Suécia sob custódia paterna). Disso resultava um mosaico mal costurado, com peças incoerentes, realçadas pelas suturas que tentavam remendar o descompassso entre a imagem cultuada pelo público e a imagem solicitada pelo regime ${ }^{88}$.

A persona pública de Zarah Leander concorria, por isso, contra a representação linear da submissão e da domesticação do desejo - nela somente se podia afirmar um compromisso provisório de postergação. De modo que os aspectos conflitantes de sua personalidade pavimentavam o contexto de recepção de seus filmes. Essa tensão extradiegética atravessava as obras, a partir do que suas personagens reproduziam a figura do feminino cindido entre os prazeres do exibicionismo e o impulso de desfrutar de sua sexualidade (assegurando, assim, espaço tanto para suas vigorosas performances vocais quanto para grandes cenas românticas) $)^{89}$.

\section{Filme musical}

A coesão do discurso publicitário em torno da modéstia de Leander nunca se sustentava porque, nas suas caracterizações, a atriz afetava poses de grande dama, sobretudo no momento de performar suas canções provocativas que, ao invés da serenidade amorosa, sugeriam prazeres promíscuos e anárquicos ${ }^{90}$. Se nenhum dos termos que a crítica lhe contesta - o exagero, a artificialidade, a repetição de papéis e a oscilação de semblantes - difere dos termos gerais pelos quais se elevava uma personalidade a estrela cinematográfica, o segredo do apelo de Leander necessariamente repousava em outro lugar. Não se confundia no que coincidia com a norma, mas naquilo que lhe era único, não na imagem visual,

\footnotetext{
88 ASCHEID, Antje. Op. cit., 159, 164-70.

${ }^{89}$ ASCHEID, Antje. Op. cit., 170, 203 e CARTER, Erica. Op. cit., 16.

90 ASCHEID, Antje. Op. cit., 165-6.
} 
mas na imagem sonora de sua performance, onde ela não encontrou rivais. Ao contrário das demais atrizes dramáticas de seu tempo, Zarah Leander não foi uma intérprete confinada ao woman's film. Todas as suas produções eram simultaneamente melodramas românticos e filmes musicais. Sua persona dramática comportava duas faces, a de atriz e de cantora, pelo que uma funcionava como o obverso da outra, tornando-a, assim, irredutível ao denominador monolítico da pura instrumentalização política ${ }^{91}$.

Seus filmes se transformavam em pretextos para a performance de suas canções. Suas mais persistentes personagens foram, por conseguinte, a grande diva dos palcos, a artista de cabaré e a enterteiner de revistas musicais, cortejadas por uma pletora de admiradores em figurações exaltadas pelo exibicionismo das interpretações e pela promiscuidade erótica das melodias. Por extensão, elas viviam uma existência desregrada ou sobrevinham de um passado confuso pelo que padeciam, filme afora, de grandes sofrimentos. As tramas desfiavam a punição dos seus excessos passionais, para as predestinarem a melancólicos desfechos nos quais ou elas, exorcizadas de seus pecados, integravam-se ao círculo social, recompensando-se no último momento com os amores amenos de galãs suaves, ou terminavam punidas com a morte. De tal maneira que o papel da diva implicava como contraparte o infalível destino de mártir92.

No papel de diva, sua voz dominava a cena que assumia a tonalidade do gênero musical. Na parte de mártir, com sua postura imponente, investia-se da dignidade de rainha do drama. Tornou-se, por isso, a atriz de sua época mais diretamente associada à categoria do filme melodramático em que o excesso de felicidade se transmutava em excesso de dor. Porém, na radical transição do filme musical para o woman's film, suas personagens desfrutavam de independência e autonomia das quais desistiam para perseguirem a realização maior do amor e da maternidade. De tal modo que ascendiam ao martírio nunca como vítimas,

\footnotetext{
${ }^{91} \mathrm{~A}$ chave para a afirmação da persona cinematográfica de Zarah Leander, observou Erica Carter, não foi, como no caso de Marlene Dietrich, a beleza, mas a qualidade única da sua voz de contralto tão poderosa que fazia dela uma presença única no cinema sonoro alemão. Estabeleceu, por esse meio, uma tensão entre sua condição de simulacro de outras estrelas e uma essência própria, encarnada na sua capacidade vocal. CARTER, Erica. Op. cit., 16, 181.

92 ASCHEID, Antje. Op. cit., 173 e ROMANI, Cinzia. Op. cit., 73.
} 
mas como protagonistas do seu próprio, ainda que miserável destino ${ }^{93}$.

Em todos esses filmes, a transição de diva a mártir implicava em tortuosas humilhações que as personagens enfrentavam com imponente altivez. Por conseguinte, elas não chegavam ao final da trama destruídas, mas esvaziadas, desespiritualizadas, alienadas em si mesmas ou indiferentes ao mundo exterior, submersas na própria interioridade como um último bastião de resistência psíquica e de reconstrução da subjetividade. Adentravam num estado alternativo de autorrealização no qual sua independência se tornava resiliente a qualquer ataque externo. Por isso, a imagem de diva não sucumbia por inteiro no calvário da mártir, mas formava com ele um híbrido em que se promovia duplamente o gozo, primeiro pelo prazer sem limites e, depois, com o sofrimento extremo.

$\mathrm{O}$ ponto de clivagem entre esses dois estados paradoxais sobrevinha invariavelmente no aguardado momento da sua performance vocal ${ }^{94}$. Ali, colocava-se instantaneamente em suspensão a ação dramática para que, em seu lugar, subisse à cena a fatal contradição entre o desejo e o dever, o erotismo e a auto-aniquilação, a diva e a mártir. Essa cesura, então, ganhava a tela em ressonantes interpretações melódicas nas quais se desmanchavam todos os sistemas de contenção dos elementos contraditórios da personalidade de Leander. Pela sua capacidade de transitar entre a leveza e a explosão, a voz da cantora preenchia o espaço da diégese e o espaço acústico da sala de exibição,

${ }^{93}$ La Habanera e Zu neuen Ufern (1937), ambos dirigidos por Detlef Sierk (mais tarde chamado Douglas Sirk em Hollywood), estandartizaram a fórmula que alinhava a dupla face de Leander - performer de canções populares e tragédienne dramática, desdobrando sua imagem como superstar dominadora e abnegada esposa e mãe. Mais tarde, Heimat (Carl Froelich) adicionou à fórmula os temas da maternidade ilegítima e do retorno ao lar. Longe de incidir numa moralidade misógina, esses filmes ancoravam o ponto de vista da personagem feminina, esmagada pelas suas fantasias românticas e pela impossibilidade de realizar o desejo do amor. Daí que da sua aniquilação como sujeito autônomo e da pulverização de seu erotismo, ela renascia mais resplandecente, como uma mulher à altura da própria sublimação. ASCHEID, Antje. Op. cit., 17386 186-93 e HALLIDAY, Jan. Conversations avec Douglas Sirk. Tradução: Serge Grünberg. Paris: Cahier du cinéma, 1997, 68.

${ }^{94}$ Numa estratégia de marketing comum na época do cinema industrial clássico e que se tornou um standard na relação de Leander com seu público, as canções de seus filmes eram transmitidas radiofonicamente semanas antes das premières para promoverem o interesse do público no lançamento da produção, e, ao mesmo tempo, firmarem a posição da estrela como atriz cinematográfica e cantora popular. Por isso, muitas de seus filmes eram arranjados em torno das canções previamente preparadas para ela. CARTER, Erica. Op. cit., 194-5 e KOEPNICK, Lutz. Op. cit., 82. 
especialmente quando descia às notas mais baixas, reforçando a absorção emocional do espectador. A linguagem corporal da atriz, invariavelmente ereta e rígida como uma estátua, enfatizava o efeito hipnótico ${ }^{95}$. Somada a essa figura majestosa, a potência vocal fazia dela um meio ideal, sugeriu Rentschler, para representar simultaneamente o fascínio de uma deslumbrante aparência externa preenchida pela profundidade espiritual da criatura humana ${ }^{96}$. Daí que, mesmo entre seus contestadores, o extraordinário excedente na sua performance vocal constituíu, a posteriori, o argumento central que a situou no território da resistência transgressiva. Nesse domínio, o excesso neutralizava qualquer possibilidade de estabilização da identidade cultural, do gênero sexual e da raça nos modos almejados pelo nazismo. Tudo isso se dissipava num esfuziante espetáculo ${ }^{97}$. Do que adviram as inúmeras ambivalências na relação da voz da atriz com o projeto de totalização da sociedade.

Beirando o registro masculino, a sonoridade baixa e densa de contralto de Leander sugeria muitas vezes uma qualidade andrógina, considerada insuficientemente feminina pelos mais puristas. Mesmo assim, ela se tornou um símbolo acústico que, pelo meio radiofônico, atravessava as fronteiras da Alemanha98. As canções faziam dela uma presença úbiqua, presente em vastos espaços geográficos e aderente em todas as camadas sociais numa experiência sonora que integrava imaginariamente o Reich. Comportando tudo o que a tradição europeia cultivara - melodia, tonalidade, alcance, harmonia e versatilidade em múltiplos gêneros e estilos - a voz se destacava da figura, desenraizava-se da presença da cantora, congregando a plateia num mesmo espaço imaginário, o da nação nórdica. Seu ecletismo, contudo, resultava em leituras opostas no momento da recepção, nem sempre úteis ao propósito racial da doutrina nazista. De um lado, ele sugeria uma espécie de internacionalismo radicado no contexto europeu. Transcendia a alta e a baixa culturas numa experiência sensorial que desafiava a fixação no tempo e no espaço, o que

\footnotetext{
${ }^{95}$ CARTER, Erica. Op. cit., 181-2, 192-3, 212.

${ }^{96}$ RENTSCHLER, Eric. Op. cit., 138.

${ }^{97}$ KOEPNICK, Lutz. Op. cit., 78.

${ }^{98}$ CARTER, Erica. Op. cit., 183, ROMANI, Cinzia. Op. cit.,, 27 e TEGEL, Susan. Op. cit., 179.
} 
convinha a um Reich que se autodenominava eterno ${ }^{99}$. Porém, de outro lado, poucos sucessos musicais de Leander aderiram ao cânone que os ideólogos nazistas definiam como apropriadamente germânico. Muito ao contrário, suas performances vocais mais poderosas transportavam o ouvinte para além das fronteiras sonoras fixadas pelo nacional-socialismo. Incidiam preferencialmente em formas definidas como degeneradas ou racialmente inferiores: foxtrote, tango, habanera, czardas, polkas. De tal modo que os filmes costurados em torno delas transportavam os espectadores para espaços e experiências exóticas, quase nunca fixadas na nação imaginária, mas na imaginação desenfreada ${ }^{100}$.

Embaladas em gêneros abastardados, enquanto o governo comissionava hinos de louvor ao sacrifício, as letras provocativas invariavelmente incidiam no tema do amor. Sugeriam prazeres promíscuos, atravessavando o Reich para o unificar não na exégese da doutrina, mas na instrução do desejo. As letras privilegiavam a predisposição para o prazer e o lamento pelo abandono para os quais as performances de Leander emprestavam uma tonalidade afirmativa num registro quase masculino que fez dela, desde o princípio, não somente uma favorita do público feminino, mas também um ídolo queer. Suas canções desciam aos subterrâneos da subversão porque davam voz aos sofrimentos e desapontamentos de seus ouvintes num período em que a felicidade pessoal se tornara um problema de política estatal ${ }^{101}$.

Nos filmes de Zarah Leander, os códigos ordinários do woman's film voltados ao enlevo masoquista eram confrontados com a originalidade transgressiva da performance vocal. De modo que neles dois discursos se

\footnotetext{
${ }^{99}$ CARTER, Erica. Op. cit., 186, 192-3, 196.

100 KOEPNICK, Lutz. Op. cit., 83-4.

101 Os títulos e as letras de suas melodias indicavam não apenas uma latente qualidade erótica. Tratavam da resistência do desejo contra os obstáculos da realidade numa persistente aderência à satisfação do prazer a qual beirava ao masoquismo. Cantou Nur nicht aus Liebe weinen " Apenas não chorem pelo amor") em Es war eine rauschende Ballnacht, Yes, Sir e Ich sehn mich nach Dir ("Eu anseio por você") em Zu neuen Ufern, Der Wind hat mir ein Lied erzählt ("O vento me contou uma canção") em La Habanera, Kann denn Liebe Sünde sein ("Pode o amor ser um pecado?) e Auf der Puszta will ich träumen ("Quero sonhar na charneca") em Der Blaufuchs. ASCHEID, Antje. Op. cit., 165-6, 205-6, 208-9, CARTER, Erica. Op. cit., 195 e RENTSCHLER, Eric. Op. cit., 128.
} 
contrapunham. De um lado, as estruturas rígidas de contenção do desejo do melodrama tradicional: de outro, a asserção do desejo pela voz andrógina com seu largo alcance sonoro e sua versatilidade estilística ${ }^{102}$.

Essa atrição era, por conseguinte, renovada com vigor nos números musicais em Die große Liebe. Os títulos e os refrões das cancões - Davon geht die Welt nicht unter (“Disso o mundo não vai acabar) e Ich weiß, es wird einmal ein Wunder geschehen ("eu sei que uma vez um milagre vai acontecer"), por exemplo - respondiam significativamente a um arco variado de ansiedades que o prolongamento da guerra impusera à sociedade ${ }^{103}$.

No nível musical, Antje Anscheid observou que a maturação da personagem Hanna era habilmente balizada pelos seus números no palco e se conformava aos desígnios da propaganda pró-bélica. De uma melodia a outra, ela paulatinamente abandonava a máscara de grande dama para se acomodar à condição de mulher de guerra. Sua única oportunidade de evocar a
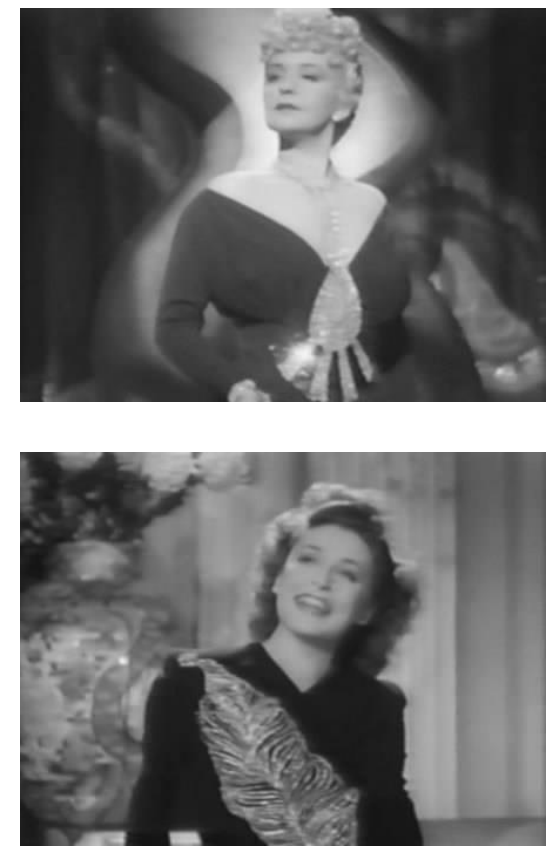

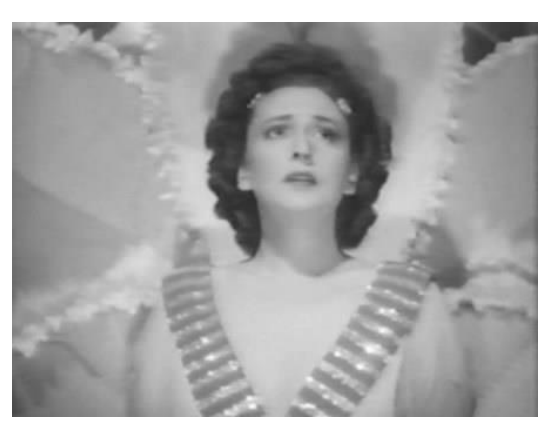

Figs 2.1, 2.2 e 2.3: Zarah Leander frivolidade e o exibicionismo de estrela do palco se restringia à sua primeira interpretação musical no ato Mein Leben für die Liebe ("Minha vida pelo amor"). O número fixava a personagem e a estrela no nível musical e visual como um produto da indústria da fantasia, mas todo o desenvolvimento posterior do filme viria indicar que a artista, com sua peruca loura e seu vestido decotado, já estava deslocada do contexto contemporâneo ${ }^{104}$.

A segunda canção, "Disso o mundo não vai acabar", que Hanna interpretava para as tropas estacionadas na França, mostrava uma mulher

\footnotetext{
102 CARTER, Erica. Op. cit., 212.

103 TEGEL, Susan. Op. cit., 180.

104 ASCHEID, Antje. Op. cit, 195, 200.
} 
transformada. Dispensara os artificios (a peruca e as roupas extravagantes) da estrela de revista musical. Apresentava-se como um "soldado da arte" prestando seu dever junto às tropas militares. Dedicava-se a esse propósito, criando uma corrente de solidariedade visualmente expressa no momento em que toda a plateia se unia e, de braços dados, acompanhava-na no refrão da melodia ${ }^{105}$.

O último número musical, "Eu sei que uma vez um milagre vai acontecer", soava como uma invocação dirigida a poderes superiores, um desejo tão encarnado como vontade que, cedo ou tarde, haveria de se realizar. Hanna agora trajava branco. Sua performance, ainda que intensa e dramática, abandonou todas as sugestões eróticas. Transfigurada por suas tristezas, de vamp evolveu a madona ${ }^{106}$.

Mesmo indexadas junto às infames Durchhaltliede ("canções de perseverança" pelo que o nazismo propugnava o otimismo cego frente à desesperante conjuntura da guerra), na performance de Leander a melodia arrastava subtextos que podiam, de um momento a outro, revertê-la como contrapropaganda. O letrista Bruno Balz redigira as canções do filme motivado pela brutalidade do interrogatório ao qual fora submetido pela SS, quando em custódia numa das prisões da Gestapo por conta de sua homossexualidade (da qual foi libertado somente pela intervenção do compositor Michael Jary). Defendia, portanto, uma leitura prevalentemente antitotalitária ao seu refrão, no que, posteriormente foi secundado por Leander e Jary. Asseverava que os versos escondiam uma finalidade contestatória, pois o"milagre" ao qual se referiam era a certeza do fim do regime nazista. Sua função subversiva, acreditavam seus artistas, atravessava subliminarmente o conteúdo da propaganda fascista e, assim, penetrava na audiência, produzindo, ali, seus efeitos mais importantes ${ }^{107}$. Disso resultava que o efeito de propaganda, uma vez lançada na cultura de

\footnotetext{
105 ASCHEID, Antje. Op. cit., 200-1.

106 A performance de Ich weiß, es wird einmal ein Wunder geschehen viria a se tornar a mais célebre interpretação de Zarah Leander, no que Lutz Koepnick identificou simultaneamente uma consolação às mulheres que labutavam na frente doméstica e um tributo à crença em Hitler como portador da arma miraculosa, a Wunderwaffe, que magicamente destruiria o inimigo. ASCHEID, Antje. Op. cit., 201 e KOEPNICK, Lutz. Op. cit., 80-1.

107 ASCHEID, Antje. Op. cit., 208, GIESEN, Rolf. Op. cit., 154, O’BRIEN, Mary Elizabeth. Op. cit., 155.e TEGEL, Susan. Ibid.
} 
massa, logo se dissipava e os subtextos que acompanhavam extradiegeticamente a persona cinematográfica de Zarah Leander voltavam a aflorar. No que explica porque, nesse momento, os informantes do Serviço de Segurança registraram a difamatória piada do encontro entre Hitler e Leander para que ambos renovassem sua crença em milagres ${ }^{108}$.

\section{Opereta bélica}

Na carreira de Zarah Leander, Die groBe Liebe avulta como um filme atípico. Mesmo seguindo a fórmula de suas produções pelo que sua personagem deveria abandonar sua carreira em benefício de um homem, foi a única realização a fazer uso de sua imagem num projeto de propaganda nazista. Também deslocava a atriz dos seus cenários típicos - países estrangeiros como a Austrália, Cuba e Escócia ou épocas recuadas no século XIX e antes disso - para representar uma mulher contemporânea na Alemanha e nos tempos de guerra. Sua atemporal persona de diva coabitava agora num mundo nada glamuroso, recortado por bombardeios aéreos, privações de produtos de consumo e separações forçadas pelas exigências militares. Filme afora, sua imagem precisava ser integrada a essa nova realidade, aceitando-a como uma oportunidade de apreciar vivências que extrapolavam seu narcisismo de artista e assim a despertavam para experiências comunais de compartilhamento e solidariedade ${ }^{109}$.

A moldura contemporânea e a conjuntura da luta militar impunham à errática personagem o entendimento de deveres inéditos com os quais ela ascenderia à altura do oficial que ansiava desposar. Necessitava aprender a esperar pacientemente e a aceitar as separações. Tinha de progredir de uma prima dona autocentrada, relutante em sacrificar a gratificação imediata a uma parceira do soldado comprometida com a vitória nacional. Ao fim, sugere Mary Elisabeth O'Brien, Hanna havia internalizado seu dever. Compreendeu que a separação fazia parte de suas obrigações, pois elas transformavam os momentos de

\footnotetext{
108 ASCHEID, Antje. Op. cit., 209.

${ }^{109}$ ASCHEID, Antje. Op. cit., 194, 196, 198.
} 
encontro romântico em experiências excepcionais. De tal maneira que a postergação do desejo imposta pela guerra servia ao propósito maior de fazer o desejo seguir adiante ${ }^{110}$.

Essa trajetória, de modo algum implicava numa verdadeira realização amorosa pela qual, como sugeria Freud, o objeto (a pessoa amada) capturou a libido narcísica, dissolvendo o ego e se colocando no lugar do ideal de ego ${ }^{111}$. Porque, à sua maneira, os dois protagonistas mantinham seus egos preservados e o narcisismo de ambos permanecia intacto até a última cena, do final feliz somente subsistia incertezas: a única expectativa que o futuro reservava aos amantes era a solicitação de paciência e resistência nos dias de espera112.

$\mathrm{Na}$ cena de sua reconciliação, Hanna e Paul não trocavam olhares apaixonados, mas miravam uma esquadrilha aérea: estavam lado a lado, e, mesmo assim, não produziam uma imagem de comunhão. A representação
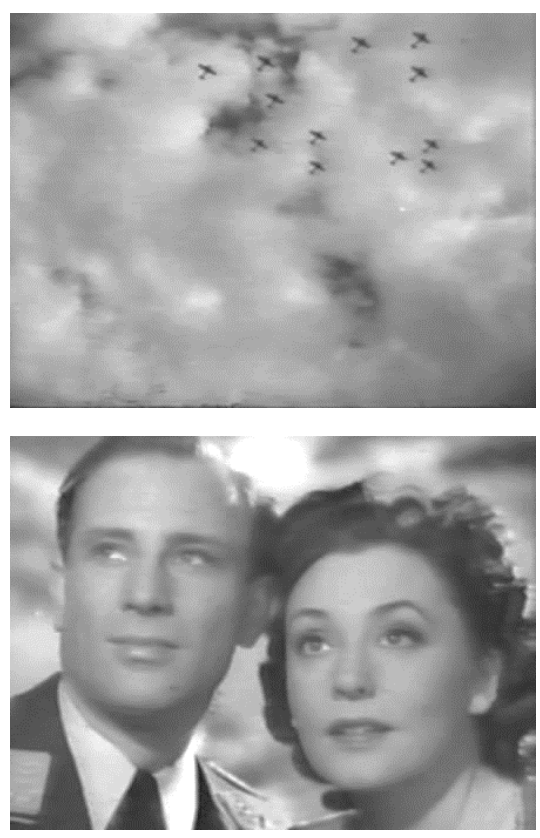

Figs. 2.4 e 2.5: Viktor Staal e Zarah Leander sinalizava que um não se dissolveu no outro, mas conservou sua própria identidade intacta. Se havia alguma sugestão de um grande amor, era a do amor próprio. Nesse desfecho, Antje Ascheid reconheceu, ao invés de um incontestável happy end, a soma das contradições que pavimentaram a carreira de Leander em todos os seus filmes pregressos. Mesmo que a guerra tivesse de ser enfrentada, remanescia na sua personagem a promessa de uma felicidade erótica, privada e narcísica a ser realizada em tempos mais prósperos. Hanna não se deixava reduzir e

110 O'BRIEN, Mary Elizabeth. Op. cit., 137.

111 Por ideal de ego, Freud definia uma parcela diferenciada do ego, uma camada insulada pela auto-observação, pelo cultivo da consciência moral, pela censura e pela repressão. Nele, o sujeito conjura inconscientemente as demandas que o meio ambiente impôs ao ego e esse não logrou efetuar. A partir disso, modela uma imagem narcisicamente idealizada de si. O ideal de ego oferece, então, uma visão à qual um ego fragilizado pode mirar e que ele persegue como que para efetuar a realização de si mesmo. FREUD, Sigmund. Psicologia de grupo e a análise do ego in FREUD, Sigmund. Obras psicológicas completas de Sigmund Freud Volume XVIII Tradução: José Octávio de Aguiar Abreu, Christiano Monteiro Oiticica. Rio de Janeiro: Imago, 1996, 113, 116-7.

112 ASCHEID, Antje. Op. cit., 202. 
somente podia ser provisoriamente contida em seus desejos conquanto lhe fosse assegurada uma possibilidade de realização de seus anseios e vontades ${ }^{113}$.

De modo similar, Paul, mesmo ferido, simbolicamente castrado pelas injúrias de seu acidente, privado de seu melhor amigo, morto em combate, também estava insulado em seus próprios pensamentos. Pois o piloto necessitou atravessar um processo ambivalente de ajuste de expectativas pelas quais sua resiliência ao desejo terminou matizada e modulada. Essa mutação na conduta de Wendlandt perfazia a fração estrutural da obra que, contrariamente ao melodrama musical encabeçado por Zarah Leander, pretendia se mostrar atraente à parcela de homens na audiência. Pois os assuntos masculinos abundavam na forma de cenas de combate, de proezas e acrobacias em aeronaves, de missões arriscadas e de demonstrações de virilidade diante do perigo. Partindo da premissa de que, pela presença de Leander, Die große Liebe se voltava somente à plateia feminina, em todas as interpretações essas sequências de combates nos céus cuidadosamente encenadas e muito apreciadas em bemsucedidos filmes de guerra receberam uma mínima consideração da crítica.

O filme, com suas vertiginosas sequências de ação militar, revelava que, além de sua marcação como woman's film, comportava também modalidades de representação especificamente voltadas ao público masculino. Tomava do cinema de guerra uma variedade de personagens e motivos, em especial a paradigmática figura do piloto da Luftwaffe produzindo manobras fulminantes com sua aeronave. Produções como Über alles in der Welt ("Acima de tudo no mundo", 1941), Stukas ("Bombardeiros”, 1941) e Besatzung Dora (“Tripulação Dora", 1943), todos dirigidos por Karl Ritter, compunham uma categoria que Courtade e Cadars nomearam "opereta bélica". Transformavam as formações da Luftwaffe em balés aéreos. Hinos de combate se apunham às explosões enquanto os Stukas valsavam no céu, derrubando tudo ao seu redor. Apresentavam formidáveis cenas de duelos celestes, visões panorâmicas dos combates e a icônia imagem do horizonte aberto para demonstrar a grande aventura que a Segunda Guerra Mundial se transformou. Em interlúdios musicais, os pilotos se juntavam 
para cantar os hinos da caserna. Confraternizavam-se, fortalecendo os laços de amizade, pelo que a morte de um parceiro inflamava ainda mais as paixões marciais. Experimentavam o que Ritter denominou "a linguagem da camaradagem". Constituiram, por isso, uma das categorias de cinema mais apreciadas pelos alemães, sobretudo nos Soldatenkinos, as unidades móveis de exibição mobilizadas para levar os filmes aos combatentes nos fronts ${ }^{114}$.

Todas essas representações, difusamente distribuídas dentro dessas obras observavam com cuidadosa fidelidade a estética dos Wochenschauen, os cinejornais semanais, com sua montagem em fragmentos breves, sua edição veloz sobreposta a vibrantes acompanhamentos musicais. E tudo isso, não almejando ao público feminino, estava fartamente distribuído em Die große Liebe.

Antje Ascheide inferiu na obra uma instabilidade de gênero excêntrica à típica fórmula de um filme de Zarah Leander que invariavelmente mesclava musical com melodrama romântico. Havia nela uma camada adicional, uma atmosfera de reiteração de guerra e, como tal, baseada nos códigos e nas necessidades masculinas ${ }^{115}$. Na mesma linha, Mary Elizabeth $\mathrm{O}^{\prime}$ Brien creditou o sucesso do filme à elaboração de uma fantasia masculina na qual a vitória militar viria miraculosamente produzir um final feliz para aqueles que se devotaram com todo coração à causa militar. De modo que, ao seu ver, a trama dramatizava não a batalha da Alemanha contra os Aliados (ou vice-versa), mas a luta entre o desejo de amor e o dever social. Toda história romântica estava, então, entrelaçada às campanhas militares numa elaboração em que a vitória no front dependia simbolicamente da solução das diferenças entre o piloto e a cantora ${ }^{116}$.

Die große Liebe desenvolvia uma peculiar ênfase na dimensão espectatorial da guerra pelo que cenas documentais penetravam na diégese, integrando-se a ela num continuum narrativo como momentos de espetáculo similares aos shows da cantora. Um procedimento de modo algum inabitual no cinema da época fascista, a sutura da trama por cenas documentais de guerra adquiriu, nessa produção, uma significação simbólica própria. Havia na obra cinco cenas

\footnotetext{
${ }_{114}$ COURTADE, Francis; CADAR, Pierre. Op. cit., 207-15.

115 ASCHEID, Antje. Op. cit., 197.

116 O’BRIEN, Mary Elizabeth. Op. cit., 136.
} 
documentais retratando sequências de ação militar aérea. Porque funcionavam como uma rota de distensão ao impasse romântico que, nesses momentos, era substituído pela excitação do combate, essas sequências produziam uma forma peculiar de cunhagem erótica. Mediante elas, a narrativa se evadia da possibilidade de realização amorosa dos personagens, engolfando-os numa trama de acontecimentos que invariavelmente os ultrapassavam. A possibilidade de satisfação sensual era, por isso, colocada à distância, dando lugar a um céu conflitado onde jamais o grande amor poderia de fato se consumar. Para além da interpretação corrente de que o filme encenava o exemplar processo de reeducação de uma mulher narcisicamente fixada em si mesma, preparando-a para assumir seu novo e desejável papel social de esposa de guerra, havia uma outra dimensão do desejo que Die große Liebe perscrutava. Ali, o filme se voltava à aventura, ao viril e ao gozo da destruição numa fantasia de persistente evasão.

A teoria feminista demonstrou que, no cinema clássico, a representação do feminino se alinhava favoravelmente com o espetáculo, o que contrariava o fluxo narrativo. Uma vez que se colocava como objeto do desejo escópico dos personagens masculinos, a mulher impunha uma interrupção na progressão do drama. Marcava um momento de fixação da atenção contra o andamento da ação. De modo que funcionava como um fator obstrutivo, um ponto de resistência, uma barreira à continuidade da história117. Uma cena em Die große Liebe, não obstante, invertia essa posição e fazia de Hanna não a estrela de uma cena, mas, ao contrário, a espectadora do outro espetáculo, a guerra emoldurada numa reportagem de cinejornal.

No código do woman's film, a situação de uma cena construída dentro da cena, onde a mulher se tornava uma espectadora, buscava atestar que seu olhar, incapaz de fixar apropriadamente as relações objetais, produzia aflições e sentimentos contraditórios pelos quais ela se confrontava com suas 
deficiências ${ }^{118}$. Nessa linha, Hanna então assistia ao drama da guerra que capturou seu amante e o levou para longe de si numa experiência de contemplação pela qual experimentava o primeiro choque contra seu narcisismo de artista. A cena do cinejornal apresentava um mundo muito mais excitante do que o do show business, o qual, para ela, estava apenas parcialmente acessível como animadora de tropas. A imagem do Wochenschau mostrava a situação do ponto de vista de um piloto que abatia o inimigo, no que Hanna (e, por extensão, a plateia de Die große Liebe) podia presumir as excitantes aventuras que Wendlandt experimentava, para as quais a presença dela não era de modo algum necessária. Seu narcisismo, por isso, fora duplamente golpeado. Diante da cena de guerra - a cena dentro da cena - Hanna se via desbancada como centro das atenções e, ao mesmo tempo, espoliada da possibilidade de adentrar no espetáculo estrelado pelo seu amante.

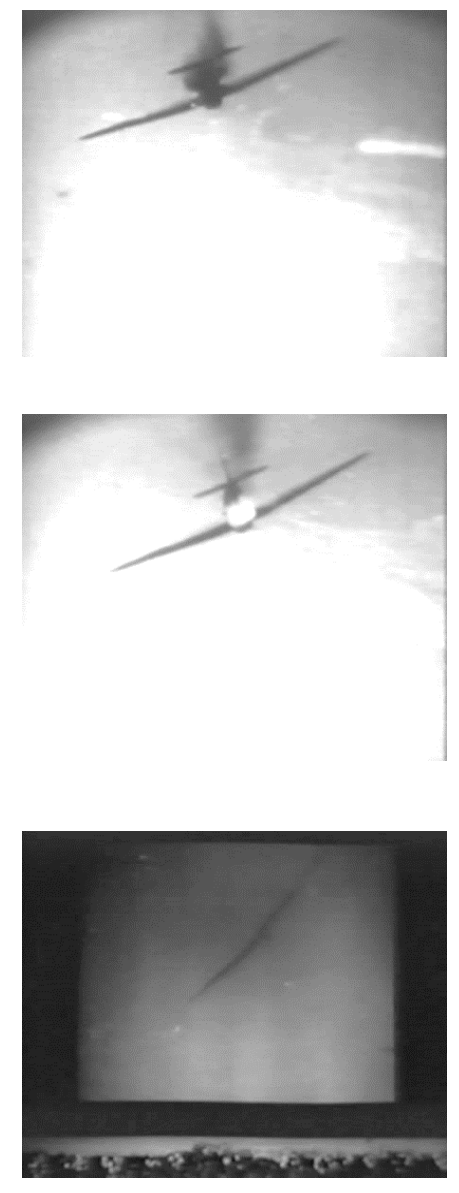

Figs. 2.6, 2.7 e 2.8 .

Mary Elisabeth $\mathrm{O}^{\prime \prime}$ Brien apontou que o filme comportava uma curiosa alternância de posições dos personagens, os quais surgiam ora como performers, ora como espectadores, numa relação de espelhamento em que a própria plateia também terminava absorvida, partilhando de dois espetáculos: o teatro de variedades e o teatro de guerra. Soldados uniformizados eram apresentados tanto demonstrando suas habilidades marciais diante de uma fascinada audiência, quanto como espectadores, prestigiando as performances igualmente cativantes do show musical. Do mesmo modo procediam os artistas. Uma vez que partilhavam dessa reversibilidade na relação escópica, os personagens se assentavam numa trama que estabelecia um nexo vital entre guerra e teatro baseado na posição espectatorial. A plateia do filme assistia, então, a um duplo show: no

118 DOANE, Mary Ann. Op. cit., 36. 
nível ficcional, o triunfo do amor romântico e, no nível documental, a antevéspera do clímax do conflito, que absorvia todos, personagens e audiência, numa fusão entre guerra e espetáculo ${ }^{119}$. Desse modo, era estabelecido um olhar cênico fracionado em dois pontos de vista, de um lado masculino, militar, documental e objetivo e, de outro, feminino, sensual, ficcional e subjetivo.

Ao contrário dos números musicais, as cenas bélicas em Die große Liebe adotavam a forma documental consagrada nos Wochenschauen que, na época fascista, promoveram uma radical mutação da percepção sensorial da guerra e, com isso remodelaram profundamente a própria experiência espectatorial das batalhas ${ }^{120}$. Fazendo uso de aviões de reconhecimento, de visores, de câmeras de bordo e das técnicas cinematográficas utilizadas para otimizar a atividade de destruição nas batalhas, os cinejornais promoveram uma crescente desrealização da carnificina ${ }^{121}$. Produziam novas sensações visuais, provendo à audiência a vertiginosa sensação das escaladas e dos mergulhos no vazio celeste ${ }^{122}$. Uma guerra de imagens e sons substituiu, assim, a guerra de objetos bélicos e, nela, tudo se oferecia ao olhar ${ }^{123}$.

119 O'BRIEN, Mary Elizabeth. Op. cit., 135, 140, 142.

120 O'BRIEN, Mary Elizabeth. Op. cit., 140 e VIRILIO, Paul. Guerra e cinema. Tradução: Paulo Roberto Pires. São Paulo: Boitempo, 2005, 27.

121 VIRILIO, Paul. Op. cit., 15.

122 CARTER, Erica. Op. cit., 207.

123 Até a eclosão da Guerra, quatro companhias de cinejornais operavam na Alemanha, a UfaTonwoche, a Deulig-Woche, a Tobis Wochenschau e a Fox tönende Wochenschau (a única empresa americana nesse mercado). Porém, em novembro de 1940, os cinejornais tornaram-se um empreendimento completamente estatizado. Com o objetivo de controlar a cobertura da invasão na Polônia e os avanços subsequentes da Wehrmacht, as quatro companhias foram fundidas. Reuniaram-se na Deutsche Wochenschau GmbH sob jurisdição do RMVP. Os cinejornais passaram a receber o título de abertura de Deutsche Wochenshau. Constituíram, daí em diante, uma ferramenta crucial na orquestração da campanha publicitária que precedeu o início da Segunda Guerra Mundial. Participaram de um largo esforço de superação da falta de entusiasmo popular frente a perspectiva do novo conflito mundial. O exército alemão passou a contar com cinegrafistas em cada uma de suas unidades. Esses profissionais formavam as PKs (Propaganda Kompanien, "Companhias de Propaganda" indicadas pelo RMVP, mas sob ordens do OKW (Oberkommando der Wehrmacht, "Comando Superior das Forças Armadas"), integradas aos regimentos para coadunar os trabalhos militares ao registro fílmico com fins publicitários. KALLIS, Aristotle A. Nazi Propaganda and the Second World War. Hampshire: Palmgrave MacMillan, 2005, 189, HOFFMANN, Hilmar. The Triumph of Propaganda Film and National Socialism, 1933-1945. Tradução: John A. Broadwin, V. R. Berghahn. Oxford: Birghahn Books, 1996, 210-3, 221-2, VIRILIO, Paul. Op. cit., 20, 142, WELCH, David. Propaganda and the German Cinema 1933-1945. Londres: I.B. Taurus, 2001, 164, 166, WELCH, David. The Third Reich Politics and Propaganda. Londres, Nova York: Routledge, 2002, 121 e WINKEL, Roel Vande; WELCH, David. Op. cit., 14, 117. 
Os Wochenschauen, antes do advento da guerra, foram um meio de expressão complexo que almejava, numa variedade de tópicos, inscrever a imagem de uma comunidade popular integrada pela cultura (o folclore, a música e os hábitos) das diversas regiões numa única Grande Alemanha. Com as duas grandes conflagrações mundiais, passaram também a incentivar o fortalecimento desses laços comunais em torno dos grandes combates e das vitórias militares ${ }^{124}$. Nesse domínio, forjavam um vínculo psicológico entre a plateia e os soldados, congregando a nação numa experiência midiática pela qual os espectadores podiam apreender emocionalmente a situação (idealizada) do conflito e perscrutar a personalidade de seus protagonistas, os combatentes nos remotos rincões da batalha125. O apogeu dos Wochenschauen coincidiu, por isso, com os sucessos fulminantes da Blitzkrieg nazista. A guerra-relâmpago se tornou o tema dominante da propaganda que, mediante ela, reforçava a confiança na perspectiva de uma rápida vitória com o fim de, assim, atrair os alemães recalcitrantes para dentro da realidade da guerra ${ }^{126}$. As reportagens promoviam, a partir disso, a visão avassaladora de um Reich transbordando em todas as direções, fundindo-se narcisicamente à Europa, sorvendo tudo ao seu redor para dentro de si $^{127}$. A guerra chegava aos seus espectadores empacotada como uma aventura, disposta em imagens que ofereciam relaxamento e diversão sob a aura da acuidade, da objetividade e da virilidade combinadas entre si. Esses filmes tornaram-se, assim, muito populares até meados de $1941^{128}$.

124 MÜHL-BENNINGHAUS, Wolfgang. Newsreel Images of the Military and War, 1914-1918 in ELSAESSER, Thomas (ed.). A Second Life: German Cinema's First Decades. Amsterdam, Amsterdam University Press, 1996, 175-84.

${ }^{125}$ KALLIS, Aristotle A. Op. cit., 191.

${ }^{126}$ KALLIS, Aristotle A. Op. cit., 10 e WELCH, David. The Third Reich Politics and Propaganda. Londres, Nova York: Routledge, 2002, 119.

127 CARTER, Erica. Op. cit., 206.

${ }^{128}$ Devido à crescente popularidade dos Wochenschauen, seu material serviu para costurar obras mais amplas, voltadas ao registro das grandes conquistas militares da Alemanha. Dos conteúdos desses semanários resultaram, assim, os filmes de montagem, documentários completos que preservaram a fulminante evolução da Blitzkrieg: Feldzug in Polen ("Campanha na Polônia", Fritz Hippler, 1940), Die Feuertaufe ("O batismo de fogo", Hans Bertram, 1940) e Sieg in Western ("Vitória no Oeste", Fritz Brunsch, Svend Noldan, 1941). Paulatinamente, as reportagens desenvolveram um estilo próprio de edição e elocução que formalizava os conteúdos numa chave emocional exaltada para estimular afetos às expensas da objetividade. Assim, retratavam a invencibilidade da armada alemã, mascaravam os acontecimentos divergentes à promoção do conflito, reforçavam uma falsa percepção de segurança e normalidade até que a realidade da 
Os produtos desse cinema militar perseguiam o objetivo de embelezar a morte, discerniu Paul Virilio. Enquadradas do ponto de vista dos soldados, a cenas das batalhas descreviam uma região abstrata da percepção, um ponto cego no qual colocavam sob sua mira um inimigo remoto, a quem mal se conseguia vislumbrar. Não se tratava, por isso, de uma guerra de destruição, mas de desrealização, de desmaterialização, um embate em que a excitação das técnicas de detecção dos sinais visíveis fazia desparecerem os demais indícios sensíveis da destruição ${ }^{129}$.

Tanto no filme documental quanto no cinema ficcional de guerra, um actante dominou a cena: o combatente que contemplava objetivamente sua missão e dela não recuava mesmo quando confundido por suas emoções. O cinema na época nazista fixou nesse estereótipo um tipo masculino ideal, não apenas o homem ariano, mas especialmente o soldado, o parceiro de armas, leal às tropas e aos camaradas com quem formava uma fraternidade viril integrada pela raça e pela ideologia. O herói militar tornou-se um paradigma de

\footnotetext{
guerra dissipou todas essas ilusões. As matérias tratando das vitórias no Oeste e a queda da França marcaram o zênite do entusiasmo popular com a campanha militar e com os Wochenschauen. Pois a conquista gálica constituiu o último grande sucesso passível de celebração pela máquina publicitária nazista. Até então, o motivo essencial de seu sucesso referia-se tanto à habilidade dos cinegrafistas em capturar eventos excitantes, quanto ao trabalho dos editores que costuravam imagens dispersas, criando narrativas vibrantes que tinham a aparência de uma reportagem factual. Mas, uma vez que dependiam de eventos exitosos no teatro de batalha, os reveses da guerra na Europa e na África a partir de 1941 produziram um efeito devastador na popularidade dos cinejornais. Após o desastre em Stalingrado e os sucessivos reveses militares, os editores e montadores passaram a recorrer a manobras diversionistas como a sobreposição de temas científicos e a repetição dos mesmos assuntos. Na ausência de novas imagens de marchas triunfais do exército sobre territórios conquistados, os Wochenschauen passaram a se evadir de reportar os embaraçosos fracassos militares, os problemas dos racionamentos, as dificuldades laborais, o escandaloso retiro de Hitler durante o período de derrotas e a devastação causada pelos bombardeios aliados nas grandes cidades para descer num mundo idealístico de música, cultura e entretenimento. Entre 1942 e 1943, a credibilidade dos cinejornais despencou. A plateia passou a rejeitar ostensivamente os conteúdos, vaiando e assoviando nos momentos de clímax, parodiando o locutor ou simplesmente se recusando a assisti-los. COURTADE, Francis; CADAR, Pierre. Op. cit., 215-8, KALLIS, Aristotle A. Op. cit., 191, 194, 197, WELCH, David. Propaganda and the German Cinema 1933-1945. Londres: I.B. Taurus, 2001, 160, 163, 167, 169-70 e WELCH, David. The Third Reich Politics and Propaganda. Londres, Nova York: Routledge, 2002, 119-20, 124-5. 129 VIRILIO, Paul. Op. cit., 39, 110.
} 
comportamento masculino ${ }^{130}$. Nos filmes ficcionais de guerra, esses personagens, conquanto já experimentassem todos os elementos de repressão necessários à disciplina da caserna, enfrentavam variados dilemas e angústias: conheciam a solidão, a privação, o medo e a perda de irmãos de armas. Compensavam-se dessas aflições com as apoteóticas vitórias da Alemanha que usualmente encerravam as tramas dos filmes.

Die große Liebe, contudo, chegou ao público quando o país não tinha nenhum triunfo para proclamar. Até então, o gênero do cinema de guerra produzira uma imagem simbólica dos combates tão exaltada quanto os períodos de celebração do sagrado. Tematizaram, nas vibrantes cenas de destruição, a face mítica do combate, pelo que se permitiam a violação dos interditos e a regressão a um tempo fora do tempo a partir do qual a sociedade podia recobrar seu vigor, atualizar-se, regenerar-se. “A guerra é a forma mais elementar de amor pela vida" escreveu Goebbels. "Pois ela franqueia o acesso à devastação e, assim, desenterra as potências subterrâneas de cada homem"131.

Pelo desterramento dessas "potências subterrâneas", a guerra, defendeu Roger Caillois, opera psiquicamente nos termos do transe religioso. Não funciona subjetivamente como um acidente da História, mas como seu motor. Deixa de ser uma demonstração de barbarismo, para se tornar o instante de autopoiése da civilização, a partir do que tudo se cria e se regenera num banho de sangue. Por isso, ela traz consigo o mesmo frenesi dos tempos apocalípticos. Os combatentes a vivem como uma paixão, procuram nela uma epifania, experimentam-na como uma orgia furiosa comutada em dever sagrado. Porque consome todas as energias e reclama para si todos os indivíduos, ela nivela os homens numa mesma uniformidade e os emparelha nos mesmos sacrifícios. Dá início a um período de intensa comunhão, solicita todos e tudo, rompe as lamelas que separam cidadãos em domínios sociais distintos e exclui tudo o que não seja grandioso e exaltado. Fundamentalmente, torna-se um momento sacro na medida em que também liberta o gozo da destruição. Somente na situação do

\footnotetext{
130 ROMANI, Cinzia. Op. cit., 25.

131 CAILLOIS, Roger. L'home et le sacré. Paris: Gallimard, 2013, 220, 227, 231.
} 
confronto estão dadas aos sujeitos as condições de experimentarem a volúpia reprimida de esmagar, descarnar, destrinchar e assassinar os objetos com que se deparam ${ }^{132}$.

A Blitzkrieg serviu como parâmetro para assinalar a ação bélica nos termos da libertinagem das festas sagradas enquanto destroçava a Europa em todas as direções. Mas, na medida em que aquela guerra de ação se transformava numa peleja sem fim, seu caráter cerimonial se esvaiu. Deixou de ser um acontecimento excepcional para se fransformar numa rotina na qual o fervor santo não tinha mais lugar. Foi o que os alemães experimentaram depois do revés em Stalingrado. De 1941 em diante, os relatórios do Serviço de Segurança indicavam que o ânimo dos espectadores com a guerra começava a declinar. Diagnosticaram os primeiros indícios de frustração com os reveses na campanha contra a Inglaterra ao fim de 1940. Constataram, nos meses subsequentes, um acelerado refluxo no otimismo popular, o qual, admitiam, fora sobrestimado nas averiguações precedentes ${ }^{133}$. Por conseguinte, o cinema voltado para a guerra viria necessariamente a remodelar seu actante, o soldado sequioso de conquistas. A seus heróis, não mais bastava despertarem para a aventura militar, excitando seu ânimo bélico a cada nova vitória, pois essas agora escasseavam. O objeto de seu prazer já não podia também ser ancorado na aniquilação de um inimigo que passou a resistir à destruição e se voltava vingativamente contra a Alemanha. De modo que um filme como Die große Liebe viria a renovar o pacto bélico não mais em torno dos acontecimentos no front de batalha, mas num outro objeto pelo que se deveria combater: o bem-estar da frente doméstica. Por isso, tanto quanto em Hanna, no piloto Wendlandt também se processava uma mutação da qual o significado espetacular da ação militar era sujeitado a um valor adicional, mais denso e extenso que a camaradagem dos parceiros de armas - a fraternidade com a sociedade civil.

A trajetória dos dois protagonistas nivelava seus desejos em perspectivas mais realistas. Hanna, observou Mary Elisabeth $\mathrm{O}^{\prime}$ Brien, viria a reconhecer que

\footnotetext{
132 CAILLOIS, Roger. Op. cit., 221, 223, 225-6, 230, 232, 235.

133 WELCH, David. The Third Reich Politics and Propaganda. Londres, Nova York: Routledge, 2002, 126.
} 
sua realização pessoal sempre dependeria dos acontecimentos da guerra. Mas também o dedicado soldado atravessava seu próprio percurso de frustrações para descobrir o valor da afeição a uma mulher e à coletividade. A princípio, perseguia a satisfação nas aventuras para as quais sua ousadia desconhecia limites. Qualquer que fosse a situação, portava-se com uma descomedida autoconfiança. Ao contrário dos seus rivais com quem disputava os afetos de Hanna, manifestava uma combinação de paixão, força e determinação, pelo que era o único personagem a fixar um tipo ideal de masculinidade. Os demais pretendentes se mostravam indecisos, vacilantes e vaidosos. Enquanto o trapezista Albert se consumia em timidez, o maestro Rudnitzky era fraco e sentimental. Nenhum dos dois tinham as incomparáveis qualidades varonis do másculo soldado. Mas tamanha paixão viril não lhe trazia a felicidade que ansiava. Paul evoluía, assim, de um aventureiro de guerra indiferente aos laços afetivos a um homem maduro e responsável, comprometido com a caserna, mas também com a mulher que o amava. Compreendia que um soldado precisava de alguém aguardando por ele tanto quanto necessitava cumprir seu código de honra militar ${ }^{134}$.

A função política de Die große Liebe, prosseguiu O'Brien, consistia em oferecer exemplos de formação e fortalecimento de vínculos entre civis e militares, acentuando simultaneamente a necessidade de união da comunidade e o reconhecimento dos esforços dos soldados. Daí que um dos prodígios miraculosos da guerra era a produção de uma atmosfera na qual as verdadeiras identidades podiam ser reveladas, ainda que às custas de sofrimentos transitórios. Ocupando todos os ambientes, ela desfazia a confusão entre a pessoa e suas personas. Na sua primeira aparição, trajando um vestido provocante e a peruca loura, Hanna afetava o papel de femme fatale. Paul tomava a personalidade encenada no palco como o self da artista. Somente mais tarde, recolhidos no abrigo antiaéreo, o piloto descobria suas demais qualidades e reconhecia nela uma mulher a quem podia amar. A trajetória de Hanna confirmava que, sob a carapaça da prima dona, repousava seu autêntico caráter, o qual se revelou 
quando ela aprendeu a renunciar aos seus desejos e a subordinar sua individualidade ao noivo e aos interesses da nação. Sublimando seu erotismo, sua volúpia, seus interesses autocentrados, tornara-se o que desse o princípio mais desejava ser, a esposa do oficial do exército. Paul igualmente necessitava superar seu mascaramento, transcendendo sua identidade de aventureiro para reconhecer a validade dos sacrifícios de Hanna e, assim, comprometer-se com ela 135 .

Mary Elizabeth O'Brien sugeriu que em Die große Liebe, a guerra funcionava, portanto, como um catalisador positivo da história de amor. Ela, na opinião da autora, desfazia os impasses e impulsionava a ação adiante. Transformava as experiências ordinárias em vivências comunais, tornando a realidade mais arriscada e incerta e, por isso mesmo, mais bela, consistente e excitante. Provia a atmosfera dinâmica que atualizava o perigo da morte e, assim, intensificava as paixões, favorecendo apenas os sentimentos imprescindíveis e verídicos ${ }^{136}$. Esses sentimentos, porém, escapavam do espaço das grandes excitações passionais para repousarem no domínio de um grande trauma coletivo.

Porque Die große Liebe formalizava no registro do espetáculo o processo de reajuste emocional de dois personagens passionais, divididos entre duas demandas extremas, o amor e a guerra, a crítica voltada ao filme proveu uma atenção marginal ao assunto que atravessava subterraneamente a trama do princípio ao fim. Die große Liebe não abordava outra coisa que o trauma da separação. Seu tema era, então, muito mais consistente e realisticamente fixado na conjuntura de seu tempo do que seu verniz matizado entre as paixões românticas e as emoções bélicas. Somente funcionava como um filme político para atestar que a separação não significava um rompimento dos laços afetivos e porque oferecia elementos de reconhecimento do profundo mal-estar que a situação do conflito causara a todas as pessoas. Ao invés de uma fantasia na qual a guerra se comutava em conto de fadas, como sugeriu $\mathrm{O}^{\prime}$ Brien, era a partir de sua insuportável malaise que o filme se organizava.

\footnotetext{
135 O'BRIEN, Mary Elizabeth. Op. cit., 140, 142-3.

136 O'BRIEN, Mary Elizabeth. Op. cit., 135-6.
} 
$\mathrm{Na}$ cena em que os amantes se reencontravam pela primeira vez depois da sua grande noite de amor, Wendlandt, incapaz de formular uma justificativa para sua ausência de três semanas, apresentava a Hanna um maço de cartas que lhe escrevera, mas que se abstivera, de postar. Naquela ocasião, temia ser rejeitado caso não apresentasse suas justificativas pessoalmente. Tudo o que podia produzir como argumento era que sua condição de oficial da Luftwaffe fora a causa de seu afastamento. Daí em diante, o romance progrediria aos solavancos, com poucos momentos de intimidade entremeados por separações e muitos desencontros. Cartas, mensagens, bilhetes, recados e telegramas passavam a funcionar como o meio de manutenção dos elos emocionais entre os amantes. Como tais, implicavam numa estetização da imagem pela qual parte da narrativa se constituía a partir da leitura dos textos escritos sob acordes de acompanhamentos musicais. Essa abordagem depositava a ênfase no único meio pelo qual Hanna e Paul podiam sustentar seu relacionamento, a palavra escrita. O que os amantes redigiam um ao outro, de modo algum subsidia a leitura de que a guerra era algo excitante e reforçava seus afetos. Muito ao contrário, o conteúdo de suas mensagens situava o conflito como um duro dever e não um prazer ou uma excitação adicional ao romance.

Essa incidência do recurso de representação do caso de amor por meio de mensagens escritas rebatia, no plano da ficção, uma pungente situação factual. Em meados de 1942, a troca de missivas havia se tornado um dos mais importantes instrumentos de manutenção do balanço emocional dos soldados. Durante os meses de luta em Stalingrado, aproximadamente três milhões de cartas foram remetidas da Sexta Divisão da Wehrmacht à Alemanha. Acantonados em bunkers e trincheiras, os soldados experimentavam intensamente as saudades de seus familiares, de seus lares e da rotina da vida

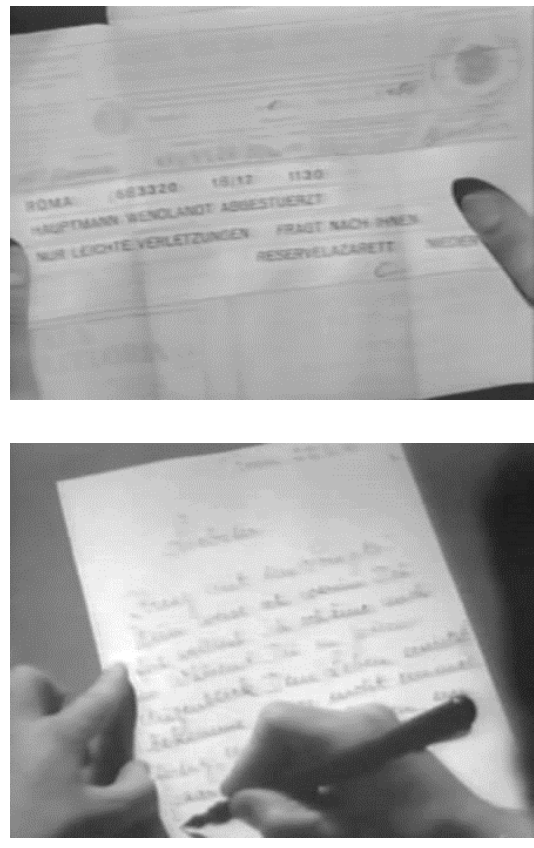

Figs. 2.9 e 2.10 . 
civil, um sentimento que somente conseguiam expressar por meio da palavra escrita ${ }^{137}$.

$\mathrm{Na}$ medida em que mais homens - esposos, pais e filhos - recebiam a convocação para se juntarem às forças armadas, essas correspondências tornaram-se o único meio de manutenção dos laços emocionais com seus parentes. As cartas eram, por isso, repletas de expressões de ansiedade e receio de que a separação forçada imposta pela guerra resultasse na alienação do apreço dos familiares deixados nas cidades e vilas. Ainda que enfrentassem embates cruentos, os soldados insistiam na afirmação dos votos de amor e lealdade com mais frequência do que descreveviam assuntos de seu cotidiano no front. A chegada de mensagens de parentes constituía, por isso, um momento de alento, esperança e reafirmação de afetos, o que produzia um importante estímulo psicoemocional nos combatentes. Por isso, mesmo nas condições de extrema precariedade na frente de batalha, nenhuma preocupação foi mais prevalente nas missivas dos soldados do que a confirmação de que os laços afetivos com suas esposas e filhos remanesciam sólidos a despeito da distância. Dessa inquietação derivavam as outras angústias que assombravam os escritos: a incerteza se seus parentes estavam vivos, a dúvida se recebiam regularmente as correspondências e a ansiedade pela demora nas respostas, o que lhes soava como uma forma atroz de abandono ${ }^{138}$.

As cartas trocadas pelos soldados com seus parentes constituem um tocante

${ }^{137}$ EVANS, Richard J. Op. cit., 413-5.

138 Esse problema, em breve, penetrou a cultura de massa em diferentes plataformas midiáticas. A célebre canção Lili Marleen, interpretada por Lale Andersen, ganhou imensa popularidade porque tratava justamente desse tema da separação, o qual já se tornara uma angústia nacionalmente partilhada. Ciente disso, o governo trabalhou para sistematizar os meios de aproximação e de manutenção dos vínculos entre as frentes militar e doméstica de guerra. $\mathrm{O}$ regime promoveu um célebre programa de rádio, o Wunschkonzert ("Pedido de concerto'), que rapidamente se tornou o mais popular entre os alemães durante a guerra. Irradiado nas tardes de domingo pelo locutor Heinz Goedecke, Wunschkonzert apresentava a leitura de cartas de soldados a seus familiares seguida de uma canção escolhida por eles e dedicada aos parentes, performada por artistas famosos. O impacto emocional do programa levou à produção do filme com o mesmo título, tratando do tema de amantes afastados pela campanha militar. Wunschkonzert, lançado em 1940, serviu como preâmbulo para Die groBe Liebe. Desse modo, o cinema e principalmente o rádio davam voz aos soldados num esforço concatenado para manter o sentimento de proximidade entre os familiares durante a separação, provendo uma ponte imaginária para eles, ladeada pela imagem e pela música. VAIZEY, Hester. Surviving Hitler's War: Family Life in Germany, 1939-48. Hampshire: Palgrave MacMillam, 2010, 36-8, 41, 45, 57, 60-1. 
episódio da guerra que Die große Liebe procurou capturar sem edulcorar ou idealizar. Porque se tratava de um sentimento de aflição experimentado por toda nação, não subsistiria sob um tratamento desonesto. De modo que a obra cumpria seu propósito político não como um mero filme pedagógico comissionado para promover a guerra e estimular o conformismo. Apropriavase de gêneros variados - o musical, o filme de guerra, o cinejornal e o woman's film - não somente com o fim de conciliar o sofrimento da separação, cambiando a emoção militar como compensação pelos afetos obstruídos. Die große Liebe oferecia o retrato de pessoas dilaceradas pelo afastamento, incapazes de conciliarem suas ansiedades com a perspectiva de enfrentarem separações mais prolongadas e perdas reais - um sentimento dolorosamente partilhado por milhares de pessoas - homens e mulheres da Alemanha - que prestigiaram a obra.

No desfecho do filme, reunidos num hospital militar, Paul e Hanna reconsideravam seus planos e contemplavam os céus que, ao invés de produzir indícios da iminente felicidade conjugal, apresentava uma esquadrilha de aviões rumando ao inferno do front soviético. Porque, no último plano do filme, ambos contemplavam o céu silenciosamente, observando a formação dos bombardeiros, para Lutz Koepnick, ao invés de experimentar a guerra como um elemento de antagonismo, a cantora admitiu que a situação do conflito podia ser um modo mais consistente de viver a paixão. A beligerância passava a ser a própria condição que tornava seu grande amor possível ${ }^{139}$. Do que se deduz que, por Hanna aceitar a guerra como um acontecimento real, seu amante podia também ascender a uma condição mais elevada da hombridade. Daí, Susan Tegel opinou que, por se engajar ao esforço militar, Hanna reabilitava tanto a si mesma quanto ao seu amante (a autora foi a única a apontar essa crucial sutileza). O desfecho indicava, pois, que a guerra se tornara para Wendlandt mais do que uma aventura masculina. Os homens no campo de batalha decerto deveriam se 
lembrar que lutavam pela mais elevada causa, a Alemanha, mas também - e, naquele contexto, isso se tornara extremamente relevante - pelas valorosas mulheres que os aguardavam, resistindo na frente doméstica ${ }^{140}$.

A crítica reiteradamente tratou Die große Liebe como um filme concernindo à plasticidade e a resiliência do desejo feminino, colocando de lado o problema de qual feminino se solicitava na moldura da fantasia masculina. Os estudos alocaram Hanna no centro da análise para enfatizar o processo de destruição do seu egocentrismo, pelo que ela se transformava na mulher que deveria ser. Sua imolação, nessa leitura, inscrevia-se pelo ataque ao seu desejo de amor e pela destruição de sua fantasia narcísica.

Hanna era uma personagem repleta de nuances que a tornavam cativante: uma narcisista exibicionista e egocêntrica incapaz de compreender que a felicidade do objeto de seu afeto não fosse idêntica à sua. Ela enxergava o mundo como uma extensão dos seus sentimentos, de modo que a privação e a renúncia do desejo lhe pareciam inexplicáveis. A guerra, a qual ela vivenciava à distância, cravou uma cunha nas suas ilusões, descentrando seu ego, atraindo sua atenção para um objeto do desejo distinto de todos os homens que a cortejavam. Descobrindo o amor em meio à guerra, Hanna aprendeu a abandonar sua posição de mulher-objeto para se tornar sujeito de seu próprio destino. Produziu sua autorrealização ao preço da renúncia de uma parte de si mesma.

Toda essa elaboração, contudo, inscrevia-se numa perspectiva ideológica mais ampla: não se restringia às ideações do feminino cotejadas pela doutrina nazista, mas eram parte do cânone da ideologia burguesa patriarcal para a qual a mulher provia a medida do masculino.

A conduta de Paul Wendlandt, sua inflexibilidade, a dureza de sua irredutível conduta e sua capacidade quase irritante de negar qualquer satisfação ao desejo de Hanna encontrava respaldo numa visão doutrinária que atribuía ao masculino uma excelsa qualidade de impermeabilidade. A noção de virilidade cultivada pelo fascismo denunciava qualquer nuance, qualquer estado de transição, qualquer indefinição ou incerteza como indícios de afeminamento - e 
não havia nada mais abominável à doutrina nazista do que a dúvida quanto à própria masculinidade ${ }^{141}$.

Sob a sombra do nazismo, os homens habitavam corpos endurecidos física e ideologicamente ${ }^{142}$. Por isso, Wendlandt rejeitava a emoção. Devotado à sua unidade, aos companheiros e às suas missões, indiferente aos seus próprios desejos, escolhia sem hesitação o dever e deixava os demais afetos em segundo plano. Colocava à frente dos seus sentimentos pessoais os compromissos de honra, devoção e lealdade. Nesse registro, a imagem de Wendlandt não produzia a representação de uma criatura humana, mas a caricaturização do masculino, pela qual o filme reincidia na figura ideal do homem que o nazismo almejava para enfrentar a situação do conflito militar ${ }^{143}$.

Essa estereotipia, contudo, era um verniz que paulatinamente se dissolvia, permitindo uma visão, de momento a momento, mais nuançada do personagem. Seu desamparo ao deixar Hanna após o primeiro encontro, sua hesitação ao reencontrá-la, sua contrariedade em não poder realizar os desejos dela - tudo isso indicava uma inadequação conflitante com a doutrina que lhe impusera o estigma da rigidez.

O drama da fixação da identidade masculina, observou Lacan, evolve em torno do jogo de mascaramentos pelos quais homens precisam se fazer parecerem como homens. Ser e parecer, nesse caso, tornam-se um mesmo problema. A dimensão da masculinidade é o semblante. Na natureza, muito usualmente, compete ao macho o trabalho de exibição para que a fêmea o reconheça como parceiro de cópula. Na sociedade humana, obstruído dos aparatos de formas e cores, os homens oferecem às mulheres o seu semblante masculino por meio de uma passagem ao ato. Se não pela violência, necessitam do instrumento de um discurso de sedução que os identifiquem como homens ${ }^{144}$.

${ }^{141}$ CHAPOUT, Joahann. Virilidade Fascista in CORBIN, Jean-JacqueS Courtine; VIGARELLO, George. História da Virilidade 3: a Virilidade em crise - séculos XX-XXI. Tradução: Noéli Correia de Mello Sobrinho, Thiago de Abreu e Lima Florênciao. Petrópolis e Rio de Janeiro: Vozes, 2013, 336, 339.

${ }^{142}$ CHAPOUT, Joahann. Op. cit., 354, 358.

${ }^{143}$ FOX, Jo. Op. cit., 96.

${ }^{144}$ LACAN, Jacques. O Seminário, livro 18: de um discurso que não fosse semblante (1971). Tradução: Vera Ribeiro. Rio de Janeiro: Zahar, 2009, 31-2. 
Do que Lacan asseverou que "para o homem, nessa relação, a mulher é precisamente a hora da verdade" 145 .

Nessa negociação, a mulher se apresenta ao homem como o divisor da sua masculinidade. Porque ela, ao contrário dos homens, tem uma enorme flexibilidade com seu semblante, pode determinar o juízo de valor que fixa ou rejeita a identidade masculina ${ }^{146}$. Lacan disse que $A$ mulher não existia, uma assunção que pretendia indicar num aforismo que a realidade do feminino tramita em termos distintos ao trauma da castração masculina. De modo que elas se alinham ao real, não ao simbólico ${ }^{147}$.

Frente à figura massiva de Zarah Leander no papel de Hanna, o personagem de Viktor Staal deve, portanto, ser contemplado não como um apêndice da narrativa, mas seu fator central. Pois ele se dirigia a uma mulher que o cinema alemão tornara sublime solicitando-lhe que descesse ao chão da realidade e o reconhecesse como um homem ${ }^{148}$. Diante dela, Paul afirmava não apenas sua afeição e sua natureza passional, mas sim sua condição subjetiva masculina. Seu encontro com Hanna não marcava a descoberta do objeto de seu desejo, mas o momento da sua verdade. Ela existia, embora ele labutasse para dissipá-la como inexistente e, nisso, sua conduta não era exatamente misógina, sexista, chauvinista ou defensiva - era parte de um processo de reconstrução identitária masculina que o filme encenava, pela qual a afirmação de Wendlandt como homem implicava em superar uma imagem $\mathrm{d} A$ mulher (a mulher enquanto essência) para afiançar seus afetos numa mulher, Hanna. O que Die große Liebe oferecia era então a fantasia masculina de fazer acessível um objeto do desejo inalcançável. Dramatizava a transformação de Zarah Leander em Hanna.

\footnotetext{
${ }^{145}$ LACAN, Jacques. Op. cit., 33.

${ }^{146}$ LACAN, Jacques. Op. cit., 34.

${ }^{147}$ LACAN, Jacques. O seminário, livro 19: ...ou pior. Tradução: Vera Ribeiro. Rio de Janeiro: Zahar, 2012,44

148 Na parte de Paul Wendlandt, a persona cinematográfica de Viktor Staal se assentava sem atritos ao personagem. Staal estabelecera uma sólida reputação de galã romântico que podia pemanecer à sombra de grandes estrelas - Zarah Leander em Zu neuen Ufern, Lilian Harvey em Capriccio (Caprichos, Karl Ritter, 1938) ou Marika Rökk em Eine Nacht in Mai (Georg Jacoby, 1938) - sem perder o lustro. Especializou-se no papel do pretendente bonito, forte, decente e confiável que se via frente ao problema de transformar mulheres excitantes e imprevisíveis em esposas pacíficas. Essa caracterização quase invariável de filme a filme estampava seus marcadores no seu personagem em Die große Liebe. O’BRIEN, Mary Elizabeth. Op. cit., 137.
} 
Representava o processo pelo qual Wendlandt aprendia a enxergar. Viu na mulher diante de si não mais $A$ mulher, mas o sujeito. E, dessa mulher, a fantasia solicitava que ela reconhecesse não o piloto, mas o homem.

Paul terminava o filme como mais um dos muitos heróis impotentes do cinema do Terceiro Reich. Convalescia, simbolicamente emasculado pelos ferimentos e assujeitado à benevolência de Hanna. No desfecho, enquanto ela recobrara a capacidade de agir e de decidir seu próprio destino, ele mal podia se mover. Não era a masculinidade de Wendlandt que triunfara pela rigidez, pois esse enrijecimento provou-se falso. Foi somente quando Hanna o encontrou debilizado, prostado numa cadeira e incapaz de se erguer, que ela se curvou e acedeu em se tornar sua esposa. Não era nem a vitória dele, nem a dela que o desfecho colocava em evidência, mas sim o contexto brutal que fazia aquela fantasia masoquista de mútua sublimação desejável. No momento em que a Alemanha nazista principiava sua derrocada, que a Blitzkrieg refluía vergonhosamente e os homens se consumiam em tristeza, longe de seus parentes e amigos, Die große Liebe se voltava à audiência para solicitar de uma grande mulher esse gesto exemplar de solidariedade. Quando os homens se mostraram abaixo de seus sonhos de grandeza, a mulher voltou a ser a medida de sua vacilante masculinidade e o estabilizador de suas conflituosas emoções.

Die große Liebe foi o último grande êxito cinematográfico de Zarah Leander, após o qual principiou seu declínio junto ao público. Ao contrário de outras personalidades artísticas que vicejaram na Alemanha nazista, sua popularidade decresceu num sintomático indício da virada na orientação estética pelo que seu público abandonou as modalidades de sublimação às quais sua persona pública tornara emblemáticas, buscando prazeres mais espetaculares com que pudessem se compensar dos choques do real149. Isso, por seu lado, tornava mais transgressiva a piada do melódico encontro entre Hitler e Leander para trocarem promessas de prodígios.

149 CARTER, Erica. Op. cit., 17. 
Tanto o Führer quanto a diva, ambos portadores da crença em milagres, foram, por assim dizer, de-sublimados pelo humor alemão. Die große Liebe havia sido lançado ao público como uma das peças de promoção de um regime que se tornava cada vez menos eficiente e mais impopular. Uma vez disponível à cultura de massa, a mensagem do filme se descolou de sua agenda e passou a significar o contrário do que deveria afirmar. Entre a doutrina que convidava a plateia a prestigiar o espetáculo da guerra e o desejo de reassentar na mulher o lastro imaginário da virilidade perdida, a fantasia flutuava, produzindo autonomamente seus próprios rebentos. $\mathrm{O}$ que reiterava, em retrospecto, $\mathrm{O}$ vislumbre do letrista Bruno Balz. Pela eterna arte do sarcasmo, o milagre ao qual sua canção vinha subterraneamente anunciar, enfim principiava a acontecer, despojando de sua dignidade tanto o enunciador do prodígio, a diva sublime, quanto o seu destinatário, o Führer infalível. 


\section{Münchhausen}

(1943)

Ainda que a Alemanha e a Inglaterra seguissem numa peleja mortal no Canal da Mancha, Goebbels sempre encontrou meios de contrabandear filmes britânicos, procurando neles boas ideias para copiar nas produções comissionadas pelo RMVP. Impressionou-se, numa dessas ocasiões, com a demonstração de proficiência tecnológica do cinema inglês em The Thief of Bagdad (O ladrão de Bagdá, Michael Powell, 1941), um filme de aventura e fantasia recheado com impressionantes efeitos especiais. Tornou-se uma de suas pretensões realizar algo ainda mais espetacular para promover o aniversário de 25 anos da UFA. Esse grande filme, para o qual não existia ainda uma história, foi confiado ao diretor Josef von Baky, há pouco credenciado pelo drama Annelie (1941). O assunto, que, no seu contexto, não poderia ser mais improvável, somente apareceu quando o diretor transmitiu a solicitação de Goebbels ao roteirista Erich Kästner para desenvolver algum script". "Se seu convite vem do maior mentiroso do mundo", disse Kästner, "porque não fazer um filme sobre seu mais próximo rival, o Barão de Münchhausen?"2.

A trama tomaria por base, então, as extraordinárias peripécias do oficial saxão do século XVIII e célebre contador de histórias, Hieronymous Karl

\footnotetext{
${ }^{1}$ Um autor de livros populares, Kästner, devido às suas tendências antifascistas, encontrava-se em uma lista negra de escritores proibidos no Reich. Por motivos nunca perfeitamente esclarecidos, Goebbels, aquiesceu com sua inclusão no projeto, conquanto seu nome jamais aparecesse nos créditos. O escritor devolveu a solicitação trocando de nome. Passou a se chamar Bertolt Bürger, literalmente "Cidadão Bertolt", o que, segundo Courtade e Cadars, prestava homenagem simultaneamente à sua cidadania perdida e ao exilado Brecht, um dos grandes desafetos de Goebbels. Karl-Heinz Schoeps, contudo, propôs outra interpretação para o pseudônimo, sugerindo que, além do prenome de Brecht, ele se referia também ao sobrenome de Gottfried August Bürger (1747-1794), um dos escritores a quem foi atribuída a autoria das aventuras de Münchhausen. COURTADE, Francis; CADAR, Pierre. Histoire du Cinéma Nazi. Paris: Eric Losfield, 1972, 296, HULL, David Stewart. Film in the Third Reich: a Study of the German Cinema 1933-1945. Berkeley: University of California Press, 1969, 253 e RENTSCHLER, Eric. The Ministry of Illusion: Nazi Cinema and its Afterlife. Cambridge: Harvard University Press, 2002,194, SCHOEPS, Karl-Heinz. Literature and Film in the Third Reich. Tradução: Kathleen M. Dell'Oro. Rochester, Nova York: Camdem House, 2013, 216.

2 COURTADE, Francis; CADAR, Pierre. Op. cit., 296 e HULL, David Stewart. Op. cit., 253.
} 
Friedrich, o Barão de Münchhausen, que começaram a circular entre 1791 e 1793, às quais Kästner suplementaria com algumas novas narrativas ${ }^{3}$.

Uma presença perene no cinema ocidental desde sua primeira aparição, sob direção de Georges Méliès (1911), entre 1913 e 1938, Eric Rentschler encontrou seis produções protagonizadas pelo pueril e incansável Barão ${ }^{4}$. A versão alemã viria a ser um caso raro e especial de filme fantástico realizado na Europa durante a guerra ${ }^{5}$. Orçado em 4,57 milhões RM (mais que o dobro para filmes de prestígio no Reich), ultrapassou o orçamento em 2 milhões para cobrir os custos de uma produção que depletou os estoques de película colorida em Agfacolor, atravessada do início ao fim por incríveis efeitos especiais e estrelada pelos grandes nomes da UFA. A preparação dos cenários e figurinos consumiu cinco meses e mais dez foram dispensados para a encenação dos efeitos. Tornou-se, portanto, um dos maiores, mais caros e mais espetaculares filmes oriundos da Alemanha nazista. Após dois anos de trabalho, a obra resultante durava mais de duas horas e meia. Várias de suas sequências foram, por isso, suprimidas e desapareceram dos arquivos do estúdio ${ }^{6}$. Resultou numa superprodução apta a demonstrar a monumental envergadura do novo cinema alemão, cujas acrobacias e malabarismos técnicos desafiavam as mais alucinantes produções hollywoodianas.

Na ressaca da acachapante derrota em Stalingrado, Münchhausen chegou ao público como um verdadeiro prodígio da técnica cinematográfica, um filme que ultrapassava os limites tecnológicos na criação de ilusões, uma obra-prima de cores e efeitos. Estreou em março de 1943 no Ufa-Palast, numa noite de homenagens ao barão da mídia e maior acionista da UFA, Alfred Hugenberg, e

\footnotetext{
${ }^{3}$ COURTADE, Francis; CADAR, Pierre. Op. cit., 296 e SCHOEPS, Karl-Heinz. Op cit., 2013, 216.

${ }^{4}$ RENTSCHLER, Eric. Op. cit., 194.

${ }^{5}$ COURTADE, Francis; CADAR, Pierre. Op. cit., 298.

${ }^{6}$ A cópia original apresentada ao público alemão durava 130 minutos. Versões diferentes foram enviadas aos territórios ocupados. De algumas delas desapareceu a sequência do relógio humano e, de outras, uma cena no estilo de commedia dell'arte na passagem veneziana. Em alguns países, as representações de nudez no harém do sultão foram censuradas e, em outros, terminaram duplicadas. Uma cena comentada por David Stewart Hull referente a uma corrida em Viena não apareceu mais em certas cópias. A sequência de uma regata em Veneza, em outras, terminou reduzida ao ponto de se tornar indiscernível na trama. Hull catalogou, enfim, cinco versões diferentes dessa mesma obra. COURTADE, Francis; CADAR, Pierre. Op. cit., 296 e HULL, David Stewart. Op. cit., 257.
} 
de premiações aos diretores Veit Harlan, Carl Froelich e Wolfgang Liebeneiner7. Münchhausen entrou no circuito de exibição no momento em que Berlim atravessava uma onda de choque pelo endurecimento dos bombardeios dos Aliados, produzindo, de sua estreia até 1944, 25 milhões de ingressos nas bilheterias ${ }^{8}$. Os historiadores e críticos, desde então, louvaram a exuberância da produção em praticamente todos os seus aspectos. A despeito das dificuldades técnicas na manipulação do Agfacolor, David Stewart Hull exaltou a cuidadosa identidade visual do filme que situava as etapas das aventuras do Barão ao matiz e a temperatura das cores na tela ${ }^{9}$. Os efeitos especiais foram considerados extraordinários, em especial o artifício da mulher decapitada da Lua e o truque de vertigem com câmeras subjetivas multiplicadas na cena do duelo de espadas entre o Barão e o Príncipe Francesco d'Estre, além das animações de objetos (as roupas saltitantes, a algazarra dos instrumentos musicais e a cinese surreal da natureza lunar) ${ }^{10}$.

O roteiro de Kästner permitiu a presença de inúmeras estrelas de primeiro e segundo escalão da UFA em participações especiais. A trama principiava no salão do castelo de Bodenweder, na Baixa Saxônia, com o que parecia ser um baile de cortesãos do século XVIII. Numa inesperada transição, a cena revelava seu verdadeiro ambiente, uma festa à fantasias na época contemporânea. $\mathrm{O}$ atual Barão de Münchhausen (Hans Albers) convidava o jovem Fritz e sua noiva Sophie para lhes apresentar um fidedigno retrato biográfico de seu antepassado, o grande Hieronymus von Münchhausen. A história então recuava, agora de fato, ao século XVIII e ao vilarejo de Bodenweder, de onde um jovem Münchhausen (o mesmo Hans Albers) partia, ladeado pelo seu fiel camareiro Christian Kuchenreutter (Hermann Speelmans), para grandes aventuras mundo

\footnotetext{
7 Por outro lado, o diretor Josef von Baky, que nunca expressou entusiasmo pelo governo, não recebeu de Goebbels nenhuma honraria por ter provido ao Terceiro Reich sua maior obra cinematográfica. COURTADE, Francis; CADAR, Pierre. Op. cit., 296, HULL, David Stewart. Op. cit., 253, 259-60e RENTSCHLER, Eric. Op. cit., 193, 197.

${ }^{8}$ SCHOEPS, Karl-Heinz. Op. cit., 214.

${ }^{9}$ Hull destacou os tons sóbrios da corte de Braunschweig, o branco e o azul do episódio russo, o dourado e o vermelho da campanha turca e as tonalidades mais escuras e contrastantes, emulando os mestres da Renascença do interlúdio em Veneza, para enfim culminar numa miscelânea de cores e estilos da paisagem lunar. HULL, David Stewart. Op. cit., 258.

${ }^{10}$ COURTADE, Francis; CADAR, Pierre. Op. cit., 297-8 e HULL, David Stewart. Op. cit., 258-9.
} 
afora. A caminho da Rússia, era assediado pelo Conde Cagliostro (Ferdinand Marian), que lhe propunha campanhas em busca de poder e riqueza para as quais o Barão não demonstrava interesse algum. Mais tarde, Münchhausen salvou a vida de Cagliostro e esse lhe retribuiu o favor com dois dotes: um anel de invisibilidade e o dom da juventude eterna. Doravante, Münchhausen viveria um tempo maravilhoso, no qual as aventuras não teriam mais fim. Deixou para trás uma antiga paixão, Louise La Tour (Hilde von Stolz) para disputar com o Príncipe Potemkin (Andrews Engelmann) os favores da Imperatriz Catarina, a Grande (Brigitte Horney). Anos depois, apaixonou-se pela Princesa Isabella d'Estre (Ilse Werner), salvando-a do serralho do cruel Sultão de Istambul, AbdulHamid (Leo Slezak).

Seu idílio, contudo, durou pouco. Em Veneza, o Príncipe Francesco d’Este (Werner Scharf), irmão de Isabella, levantou a Inquisição contra o Barão e aprisionou a Princesa para sempre num convento. Münchhausen e Kuchenreutter conseguiriam escapar dos inquisidores fugindo pelo firmamento no prodigioso balão do Doge veneziano. Atravessaram os céus e desembarcaram na Lua. Ali se depararam com um mundo assombroso, onde as crianças nasciam em árvores e as mulheres podiam descolar a cabeça do corpo. E porque um dia lunar correspondia a um ano terrestre, Kuchenreutter rapidamente sucumbiu de velhice e morreu. Seu corpo se desvaneceu como fumaça. Até então, ao Barão nada havia sucedido de tão doloroso. Doravante, Münchhausen atravessou solitária e erraticamente a História. Esteve na Revolução Francesa, nas guerras napoleônicas, lutou na Lombardia em 1848 e depois no México. Aos trezentos anos de idade, mas ainda preservado em sua juventude, desposou uma gentil donzela, por quem renunciaria à eternidade para viver a velhice com ela e, depois, morrer ao seu lado.

Para a maior parte dos historiadores, Münchhausen foi o resultado cinematográfico do desastre alemão em Stalingrado. A monumental derrota na Rússia marcou o momento de clímax da Segunda Guerra Mundial e o ponto de 
virada dos combates, pelo que a Blitzkrieg começaria a regredir. Seria rapidamente acompanhada por dois funestos acontecimentos: o desembarque das forças anglo-americanas no norte da África pelo Estreito de Gibraltar e a vitoriosa resistência dos ingleses em El Alamein no Egito, o que interrompeu a fulminante campanha do Marechal Erwin Rommel, privando a Alemanha do estratégico acesso ao Canal de Suez ${ }^{11}$.

Stalingrado marcou assim um ponto de virada também na política cinematográfica. A contrapartida da guerra total seria, dali em diante, a provisão de mais entretenimento para distrair o público como compensação pelo revés ${ }^{12}$. Porque foi concebido em meio à maior crise do regime, historiadores e críticos declararam unanimemente que Münchhausen constituiu um fenômeno excêntrico na cinematografia do Terceiro Reich. Esquadrinharam na obra uma pletora de elementos ostensivamente contrários à doutrina nazista e se detiveram no peculiar problema de interpretar o propósito de uma superprodução

${ }^{11}$ EVANS, Richard J. The Third Reich at War: How the Nazis Led Germany From Conquest to Disaster. Londres: Penguin, 2009, 467, 483 e SHIRER, William L. The Rise and Fall of the Third Reich: a History of Nazi Germany. Nova York: Simon\&Schuster, 2011, 920, 922, 928, 933.

12 Nas suas primeiras manifestações, o nacional-socialismo almejava encetar no cinema uma afirmação da excelência e da excepcionalidade do gênio criativo alemão. A virada doutrinária que, nos anos 1930, capturou a indústria cultural alemã foi acompanhada de um esforço concentrado para produzir uma cinematografia original não somente nos conteúdos, mas notadamente no aspecto formal. Os filmes passaram a perseguir um novo estilo de realismo pelo qual pretendiam capturar a alma nacional, contrapondo-se ao degenerado naturalismo weimariano e ao ilusionismo do estilo de Hollywood. Uma variedade de práticas técnicas e marcadores estilísticos - planos sequenciais, iluminação difusa que refutava o efeito de halo e cenários naturais - surgiram como índices visuais dessa nova cinematografia. Até 1941, Goebbels ainda solicitava uma arte alemã que não emulasse cegamente o cinema estrangeiro, mas cultivasse as qualidades pictóricas e artísticas da nação. Almejava a filmes que formalizassem grandes ideias em concepções artísticas originais e suficientemente apelativas às massas para seu esclarecimento, instrução e edificação. A reviravolta russa, não obstante, dissipou o contexto para criações voltadas à sublimação. O regime colocou de lado sua preocupação em engendrar uma nova arte cinematográfica para perseguir pragmaticamente o entretenimento de massa em formas espetaculares como Münchhausen e Kolberg (Veit Harlan, 1945). E mesmo esses filmes monumentais rapidamente reverteriam em exceções. Pois, em meados de 1943, os nazistas renunciaram a todos os esforços de determinar os paradigmas de uma nova arte alemã. A guerra arrastara todos os interesses, atenções e recursos, esvaziando os quadros profissionais da Câmara de Cultura do RMVP, deixando projetos dispendiosos de lado, cortando verbas de teatros, cinemas e museus. CARTER, Erica. Dietrich's Ghosts: the Sublime and the Beautiful in the Third Reich Film. Londres: British Film Institute (BFI), 2011, 17, 36-41, CLINEFELTER, Joan. Artists for the Third Reich: Culture and Race from Weimar to Nazi Germany. Oxford, Nova York: Berg, 2005, 110, PETLEY, Julian. Capital and Culture: German Cinema 1933-45. Londres: British Film Institute (BFI), 1979, 102, 104 e WITTE, Karsten. How Nazi Cinema Mobilizes the Classics: Schweikart's Das Fräulein von Barnhelm (1940) in RENTSCHLER, Eric (ed.). German Film \& Literature: Adaptations and Transformations. Nova York, Londres e Methuen, 1986, 104. 
comissionada como propaganda do regime, mas que não continha nenhuma propaganda.

Do ponto de vista de Linda Schulte-Sasse, desde que a função da obra era homenagear o jubileu da UFA e, por extensão, a arte cinematográfica, o filme se tornou marcante pelo seu estilo autoconsciente, pelas reflexões alegóricas sobre o próprio meio, pelo investimento no fantástico, no imaginário e no ilusório e pelo confronto entre duas temporalidades, os séculos XVIII e $X^{13}$. Foi secundada, nesse único aspecto, por Eric Rentschler que reconheceu em Münchhausen uma produção singular porque suas operações narrativas se distanciavam dos códigos do filme clássico. Como não perseguia uma trama, atraía então a atenção para os próprios processos de fabulação. Segmentado em vários episódios, evocava as estruturas das grandes realizações do período weimariano, voltando-se não para linearidade dos enredos, mas à autorreflexão sobre os meios pelos quais as histórias vêm à luz ${ }^{14}$. Formalizava um meta-cinema não apenas porque Münchhausen era um especialista na arte de narrar histórias, um misto de mestre de cerimonias e encantador, mas pela sua habilidade em desmistificar o logro da cena para denunciar, nos momentos menos prováveis, os artifícios da técnica cinematográfica. Buscando estabelecer contato direto com o espectador, saudando-o ou solicitando sua cumplicidade com o olhar, expunha a realidade de uma arte voltada ao ilusionismo. No nível simbólico, os dotes de Cagliostro ao Barão, o anel mágico que lhe provia o controle de sua própria presença visual e o encantamento que o tornou imune às marcas do

\footnotetext{
${ }^{13}$ No protagonista, Schulte-Sasse identificou, em primeiro lugar, uma potente alegoria do próprio cinema. O Barão, segundo a autora, presentificava tanto os poderes materiais do meio cinematográfico sobre o tempo e o espaço, quanto seu apelo e fascínio junto às plateias. Como a própria imagem de cinema, Münchhausen jamais envelhecia. Tampouco retinha no seu corpo os danos causados pelas suas aventuras. Tal qual a arte cinematográfica, era uma presença ubíqua. Atravessava países, continentes e o próprio espaço celeste. Tinha, além do dom da eternidade, o poder de se fazer invisível e de romper com a barreira que separava os espaços do filme e da audiência para se dirigir aos espectadores por meio de olhares e piscadelas. SCHULTE-SASSE, Linda. Entertaining the Third Reich: Illusions of Wholeness in Nazi Cinema. Durhan, Londres: Duke University Press, 1996, 302-4.

${ }^{14} \mathrm{O}$ recuo ao cinema weimariano, observou Rentschler, espalhava-se nos cenários exóticos e nos ambientes inusitados: a opulenta corte de Catarina, a câmara fantástica de Cagliostro, o serralho do Sultão, o Carnaval de Veneza e a surrealista paisagem da Lua, quando enfim o filme alcançava os confins do primeiro cinema de Méliès. RENTSCHLER, Eric. Op. cit.,198, 200.
} 
envelhecimento, produziam o código pelo qual o filme se referia à própria mídia. O que, para Rentschler, situava a obra num debate mais amplo dos sistemas de ilusão formulados pela arte cinematográfica ${ }^{15}$.

Não era, porém no seu investimento metalinguístico que Münchhausen parecia descolado de seu contexto social e político, mas pelo caráter errático, mundano e lúbrico do seu protagonista e pela absoluta falta de propósito para suas deambulações mundo afora. Andarilhos e viajantes, incapazes de compreender a alegria do sedentarismo na terra natal eram tratados com suspeição no cinema do período nazista. Mesmo quando se tratavam de exploradores e aventureiros movidos pela ambição de conquistarem novos territórios a fim de expandir os domínios do Reich, seus destinos evolviam não para o cômico, mas para o trágico ${ }^{16}$. Disso, o filme sugeria uma problemática deficiência nas qualidades raciais do Barão que comprometiam seu pedigree ariano e, com ele, todo o edifício doutrinário do nacional-socialismo baseado no Volk e na Heimat.

O filme apresentava temas fundamentais ao nazismo acerca da história nacional, da organização social, da personalidade masculina e das identidades racial e sexual num tratamento tão heterodoxo que, sugeriu Linda Schulte-Sasse, parecia subvertê-lo em todas as suas frentes. O Barão não se dedicava a missão alguma. Vivia uma existência estritamente privada, rejeitava aderir a qualquer coletividade e saltava de um meio social a outro em busca de locações prazerosas que satisfizessem sua indomável imaginação. Não se assemelhava nem de longe ao novo homem fascista, mas, surpreendentemente, ao judeu. Pois eram ambos, na expressão de Schulte-Sasse, uma mesma "criatura apocalíptica", orientados pelo seu individualismo, mestres que dominavam a própria imagem e conduziam os fios de suas narrativas, conquistadores de espaços e de mulheres

\footnotetext{
15 Já na primeira sequência, o filme desmascarava os procedimentos técnicos de fabricação do ilusório pela simples manipulação do enquadramento da cena e da intensidade da luz. $\mathrm{O}$ espectador acompanhava o baile cortês ambientado no século XVIII. Todos os elementos situavam a ação nesse contexto. Porém, quando a câmera se deslocava para o detalhe do interruptor de luz e essa se espalhava sobre a cena, a ilusão se desmanchava. Em seu lugar surgia o baile de fantasias situado na época contemporânea. RENTSCHLER, Eric. Op. cit., 198, 204, 207. 16 RENTSCHLER, Eric. Op. cit., 141.
} 
(aspecto, aliás, ausente na referência literária da obra $)^{17}$.

Do mesmo modo que o Judeu Süß, o Barão fazia de si mesmo o enunciador textual de sua saga. Beneficiando-se da habilidade do mascaramento para mistificar os poderosos, nem Süß, nem Münchhausen jamais precisavam servir a ninguém. Como o judeu, o Barão também neutralizava a potência viril de seus adversários, castrando-os simbolicamente ${ }^{18}$. O inconfundível desdobramento especular pelo qual Münchhausen se alinhava ao estereótipo do judeu fixado em

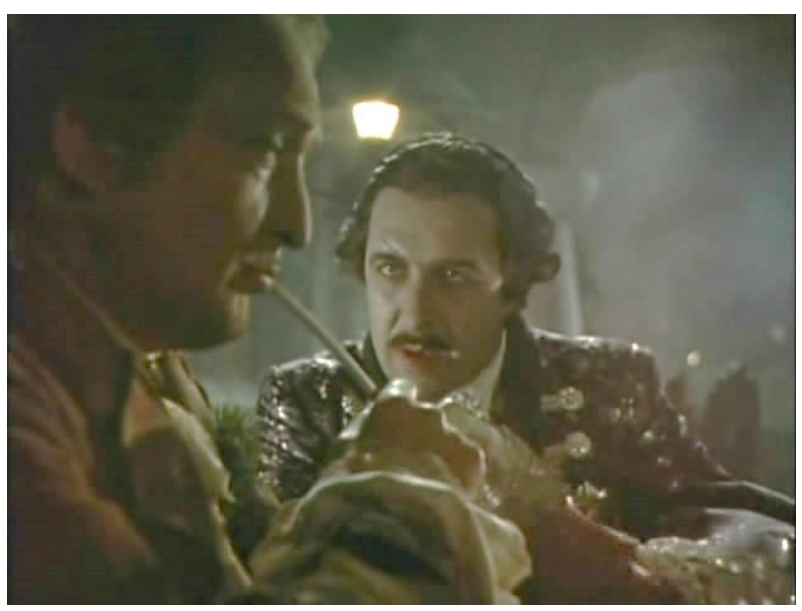

Fig. 3.1: Hans Albers e Ferdinand Marian. Jud Süß era estabelecido, para além de qualquer contestação, na sua formidável amizade com o Conde Cagliostro. Por seu caráter e sua aparência, Cagliostro se dispunha claramente na trama como um criptojudeu. Encarnado por Ferdinand Marian, a conexão entre o personagem e Süß não podia de modo algum passar despercebida.

O Conde fazia apenas duas aparições significativas no filme, ambas sensacionais. Era prontamente reconhecido como um farsante, um usurário e um conspirador implacável. Invadia a cena vindo de lugar algum. Ominosos sinais de mau augúrio precediam sua entrada na trama. Cortejava o Barão com promessas de riqueza e poder. Num diálogo elíptico, repleto de subliminares, convidava o Barão a se aproveitar de seu perfil ariano para conquistarem países estrangeiros. Mais tarde, assim como Süß, Cagliostro cumpriria o papel de Mefisto e agraciaria Münchhausen com o dom da imortalidade, transformando-o no super-homem decantado pelo nacional-socialismo ${ }^{19}$.

Não apenas pela prodigalidade de seus efeitos especiais, mas, sobretudo

\footnotetext{
17 SCHULTE-SASSE, Linda. Op. cit., 302-3, 307.

${ }^{18}$ O Príncipe Potemkin perdia um olho numa disputa com armas com o Barão e o Príncipe d'Estre terminava literalmente nu, exposto ao ridículo ao tentar enfrentá-lo num duelo de espadas. SCHULTE-SASSE, Linda. Op. cit., 308-9.

19 SCHOEPS, Karl-Heinz. Op. cit., 218, RENTSCHLER, Eric. Op. cit., Op. cit., 205, 207, 210 e SCHULTE-SASSE, Linda. Op. cit., 309, 311.
} 
pela originalidade e ousadia da estrutura narrativa e pelas alusões subliminares à realidade fascista, Münchhausen tornou-se um tópico de vibrantes debates. Dividiu a crítica em dois campos irredutíveis que se opuseram entre localizar o filme como uma obra de resistência da cultura de massa ou uma forma lapidar de propaganda fascista. No primeiro grupo, Linda Schulte-Sasse ressaltou as alusões ao contexto político imediato da obra, pelo que o conteúdo extradiegético produzia duplos sentidos aos diálogos. As referências explícitas à conquista da Polônia, ao governo autocrático do Sultão, aos trabalhos da Inquisição em Veneza e os frequentes comentários aos temas do tempo e da morte produziam a imagem de um mundo terminal, despedaçado pelo caos e politicamente desorientado. Münchhausen circulava por lugares transtornados, no que não era difícil vislumbrar uma imagem da própria Alemanha. A partir do que Schulte-Sasse concluiu que o filme explorava simulacros não para produzir utopias, mas como investimentos da imaginação libertada das constrições. Assim, suas elaborações não se continham na fronteira da doutrina fascista, mas a ultrapassavam transgressivamente ${ }^{20}$.

Shulte-Sasse contestava a celebrada leitura de Eric Rentschler, que, contrariamente, vislumbrou no filme mais uma situação de defasagem entre o contexto de recepção de uma obra e o prestígio que o revisionismo da crítica lhe apôs no pós-guerra. Situou Münchhausen dentro de um inequívoco projeto de autopromoção do regime, orientado à galvanização do ânimo popular para o tornar menos sensível à radicalização do conflito militar. Sua reputação de cult subversivo foi, por conseguinte, um equivocado acréscimo posterior ${ }^{21}$. Münchhausen era, na sua opinião, a fisionomia cinematográfica da guerra total anunciada por Goebbels em 1943 que, agora, voltava-se diligentemente para o

\footnotetext{
${ }^{20}$ Fosse como um cínico comentário dos nazistas a respeito de si mesmos e de seu insuperável aparato de ilusão ou um cifrado tratado de contestação crítica disfarçado de filme fantástico, Münchhausen, defendeu Schulte-Sasse, expressava o desejo fundamental de se livrar da ordem existente, de vagar irresponsavelmente e se misturar sem nunca se perder. De modo que qualquer que fosse o objetivo de seus idealizadores, o resultado final, opinou a autora, oferecia uma violenta subversão à obtusa pretensão do regime em fazer da comunidade racial o valor supremo do desejo masculino. SCHULTE-SASSE, Linda. Op. cit., 312, 315-6.

${ }^{21}$ RENTSCHLER, Eric. Op. cit., 196-7, 207.
} 
campo da mistificação ${ }^{22}$. Rentschler indicou que o filme exaltava a máquina bélica: a espingarda de Christian, cujo disparo alcançava 110 milhas, a bala de canhão sobre a qual o Barão desfilava pelos céus, além do maravilhoso balão do Doge. Essas representações repercutiam na obra os rumores que o regime disseminava sobre o advento de novas e poderosas armas capazes de reverter a má sina alemã na guerra ${ }^{23}$. Embalado como um produto de arte total, traficava essas e outras ilusões, perscrutando propositalmente desejos subterrâneos para promover o mito do bom homem nazista enquanto oferecia uma face suave à dureza do estado de exceção ${ }^{24}$. Do que Rentschler fixou no personagem uma poderosa figura ideológica. Nem uma réplica do Führer, nem uma reencarnação caprichosa de Frederico, o Grande, Münchhausen era o indivíduo que fabricou seu corpo como uma realidade estética. Fez de si próprio um ícone animado, uma criatura sobre-humana cujos poderes lhe garantiam o domínio sobre todas as narrativas. Tornou-se o homem que se construiu como uma obra de arte ${ }^{25}$. Longe, então, de rejeitar o ideário fascista, o filme o perseguia, entrevendo no seu protagonista a imagem que Lacoue-Labarthe e Nancy fixaram como o axioma quintessencial do nazismo: “a formação do povo alemão na, pela e como obra de

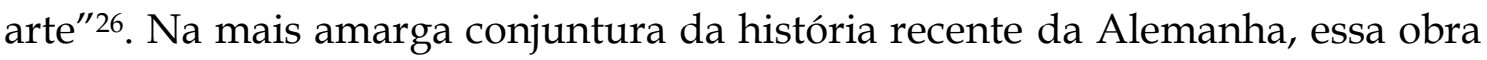
de arte humana se lançava em contentes caminhadas pelo globo terrestre como um judeu errante. Abria as portas de um mundo falso para uma plateia

\footnotetext{
22 "Guerra total" foi o conceito que chegou ao público num abrasador discurso de Goebbels em fevereiro de 1943. Porquanto Hitler atribuísse a derrota no Leste à inoperância dos seus aliados romenos, italianos e húngaros, Goebbels reconheceu que a vitória soviética em Stalingrado fora subsidiada pela mobilização da população civil russa, a qual excedia largamente o esforço na frente doméstica alemã. Atribulado pelo silêncio público de Hitler, Goebbels tomou a iniciativa de despertar o ânimo popular e promoveu uma elocução no Sportpalaz para inflamar a opinião pública em torno da noção da "mais total de todas as guerras" da qual se apresentou como o mentor espiritual. Discursou a uma plateia de dignitários do regime para quem, no clímax da elocução, lançou dez perguntas: "vocês estão decididos a seguir o Führer na dura luta pela vitória?", "vocês querem a guerra total?", "vocês confiam no Führer?", etc. O público respondeu às questões com um invariável "sim", em meio a uma onda de ovações. O que fez do pronunciamento um dos mais célebres discursos de guerra em qualquer época. LONGERICH, Peter. Joseph Goebbels. Tradução: Luiz A. de Araújo. Rio de Janeiro: Objetiva, 2014, 515-9.

${ }^{23}$ RENTSCHLER, Eric. Op. cit., 202-3 e SCHOEPS, Karl-Heinz. Op. cit., 218.

24 RENTSCHLER, Eric. Op. cit., 212-3.

${ }^{25}$ RENTSCHLER, Eric. Op. cit., 209-10.

${ }^{26}$ LACOUE-LABARTHE, Philippe: NANCY, Jean-Luc. O mito nazista seguido de O espírito do nacional-socialismo e o seu destino. Tradução: Márcio Seligmann Silva. São Paulo: Iluminuras, 2002, 45-6.
} 
desesperada em busca de escapismo, que diariamente precisava cumprir os ritos da denegação, rejeitando a realidade da guerra e o pressentimento do genocídio judaico $^{27}$.

Dentre seus críticos, Rentschler foi o único a descredenciar o fato de que, não tendo nenhuma missão que conduzisse sua vida, Münchhausen não servia apropriadamente como veículo de uma ideia, fosse pró ou antifascista. KarlHeinz Schoeps observou que o personagem se movia apenas motivado pelos seus interesses privados ${ }^{28}$. Mantinha, então, afinidades com os desenraizados, os turbulentos, os aventureiros, os rebeldes e todas as criaturas que, imaginariamente, subsidiam a atemporal fantasia da liberdade. Portanto, qualquer que fosse o ponto de vista político da obra, Münchhausen transitava na contramão de todas as tendências prevalentes no cinema tanto de sua época, quanto de seu contexto, os quais demandavam sacrifícios e heroísmo ao invés da rendição à folia sem fim.

Em oposição aos grandes filmes antissemitas que dominaram o cenário cinematográfico dos primeiros anos da década de 1940 - Jud Süß, Die Rothschilds Aktien aufWaterloo ("Os títulos dos Rothschilds em Waterloo", Erich Waschneck, 1940) e Der ewige Jude (O judeu eterno, Fritz Hippler, 1941) - a produção abria a cena a um herói ariano alinhado a um criptojudeu, que atravessava o mundo, sem pátria e sem raízes, sem laços familiares e sem propósito. Porque dispensava o amor à nação do rol de seus afetos, o personagem seguia a orientação contrária à corrente do Heimatfilm ("filme da pátria”), também prevalente na propaganda cinematográfica nazista ${ }^{29}$. As aventuras peculiarmente urbanas e em meio à alta

\footnotetext{
27 RENTSCHLER, Eric. Op. cit., 213.

28 SCHOEPS, Karl-Heinz. Op. cit., 218.

29 Os Heimatfilme surgiram em 1910, atravessando estavelmente o cinema alemão desde sua origem até o pós-guerra. Constituíam um gênero tipicamente germânico que não apenas oferecia enredos para evidenciar a paisagem natural da Alemanha, os costumes, as canções, os vestuários tradicionais e os espaços arquitetônicos das antigas cidades. Pretendiam, sobretudo, apresentar criticamente o contraste entre a saudável vida no meio rural e a decadência do meio urbano contemporâneo. No início dos anos 1930, constituíam um gênero plenamente desenvolvido, orientado para a realização de uma articulação harmônica entre o homem alemão, a paisagem natural do país e a música folclórica. De tal maneira que se tornariam uma forma ideologicamente apropriada para a mentalidade fascista, a qual se emprenhou em deslocar a ênfase dos espaços físicos para a ideia mais abstrata de comunidade racial. Do que resultaram os grandes filmes no gênero, Der verlorene Sohn (O filho pródigo, Luis Trenker, 1935), Heimat (Pecado de amor, Carl
} 
aristocracia distanciavam-no simultaneamente do tradicional Geniusfilm e também do Bergfilm com suas imagens da transcendente simbiose entre o homem e a natureza ${ }^{30}$.

Tomado sob o viés do seu conteúdo político, Münchhausen permaneceu como um objeto opaco, servindo, assim, para qualquer leitura. Esse turvamento se adensou na medida em que as análises se contentaram em transladar o propósito político da obra pelo caráter impenetrável do personagem. Esse, de sua parte, não se prestava a nenhuma outra utilidade do que funcionar como elemento de sutura para uma narrativa voltada à superposição de fantasias. Como tal, o texto do filme atravessou confusamente seu contexto para chegar à contemporaneidade motivando mais dúvidas do que esclarecimentos. Pois, enquanto personagem, o Barão pertencia ao domínio narrativo. Seu meio ideológico era o da fabulação voltada ao prazer de fazer boas histórias seguirem adiante. Nesse domínio, Münchhausem resiste como uma história sem fim. O trajeto do filme coincidiu com a sina do personagem, que se predestinou a viver para sempre confundindo seus interlocutores ávidos de apreender a lógica oculta sob seus atos ilógicos. Porque a obra foi precisamente constituída para suspender a lógica, suas operações se voltavam à censura, não dos elementos da sua conjuntura política, mas das relações de coerência. Os protocolos narrativos de Münchhausen se igualavam ao trabalho da censura onírica que obstrui o funcionamento ordinário do princípio da realidade e, consequentemente, avança além do princípio do prazer. Como nos sonhos, os quais as estruturas do filme trabalhavam para emular, seus conteúdos ideológicos (mais complexos e difusos do que os dogmas da doutrina) parecem suprimidos quando, de fato, estão

Froelich, 1939) e Heimkehr ("Volta ao lar", Gustav Ucicy, 1941). COURTADE, Francis; CADAR, Pierre. Op. cit., 158, 288-91 e MOLTKE, Johannes von. No Place Like Home: Locations of Heimat in German Cinema. Berkeley, Los Angeles: University of California Press, 2005, 27-9.

30 Realizações grandiloquentes, os Bergfilme ("filmes alpinos") estetizavam a luta de um personagem para superar a si mesmo na escalada de uma montanha. No cume da cordilheira, a provação física era recompensada pela glacial purificação do frio e da neve. As ficções montanhesas simbolizavam a vertigem da elevação numa contemplação estática e estoica da beleza abissal da paisagem. Essas obras celebravam a habilidade e a destreza, a vitória dos fortes sobre os fracos e a aspiração a um gozo transcendente, espiritual, dessexualizado num cenário virgem e sem limites. Para referências sobre o Geniusfilm e sua relação com filmes biográficos, cf. pg. 52, Capítulo 1. 
ostensivamente manifestos. Tornaram-se invisíveis porque foram disponibilizados por inteiro ao olhar onde não se supõe que deveriam estar.

\section{$\underline{\text { O Maravilhoso }}$}

As imagens e ideias dos sonhos, esclareceu a teoria psicanalítica, aparecem deformados à luz da razão porque se sujeitaram a um trabalho de censura inconsciente, o qual atenuou o material original, tornando-o significativo mediante aproximações e alusões ao invés de escancarar o conteúdo. Por causa dessa censura, esse conteúdo torna-se resistente à interpretação, pois os elementos obstruídos constituem desejos recalcados, cujo aparecimento no consciente resultaria em angústia e perturbação psíquica. Por conseguinte, na experiência onírica, a extensão da deformação de um conteúdo pela censura equivale à dimensão do desejo censurado ${ }^{31}$.

Mediante a censura um conteúdo desejável, porém inaceitável, encontrou a forma permissível para ser fruído sem incidir no risco de recriminação ou culpa. De modo que ela não se dispõe a impedir a manifestação do elemento proscrito. Muito ao contrário, constitui um meio para o fazer aflorar numa forma original, capaz de atravessar a percepção sem resultar em rejeição. A censura, nesse nível, não se comporta como uma barreira, mas como um desvio. Constitui, de acordo com Christian Metz, um sistema de deflexão que refrata a rota do sentido, pelo qual o que estava reprimido encontra uma trajetória até o consciente. O que se censura são os processos secundários que apartam, isolam e definem os objetos, separando-os dos sujeitos. A deflexão empurra a representação em direção ao processo primário, implodindo a lógica da unicidade, confundindo coisas e ideias com a estrita finalidade de promover uma satisfação imediata dos desejos ${ }^{32}$. A

\footnotetext{
${ }^{31}$ FREUD, Sigmund. Conferências introdutórias sobre a Psicanálise (Partes I e II): A censura nos sonhos: Conferência IX in FREUD, Sigmund. Obras psicológicas completas de Sigmund Freud. Tradução: José Octávio de Aguiar Abreu e Christiano Monteiro Oiticica. Rio de Janeiro Imago, 1996, 142-150.

$32 \mathrm{O}$ fenômeno denominado processo primário ocorre no nível inconsciente, em particular nos sonhos, promovendo ali um fluxo autônomo de energia, baseado em mecanismos de condensação e deslocamento, pelo que ideias e imagens distintas são livremente cambiados, visando à satisfação do princípio do prazer. Já nas fantasias elaboradas no estado consciente, houve correções governadas pelo princípio da realidade, às quais Freud denominou processos secundários. A
} 
expressão refratada pelo trabalho da censura, portanto, implica que a interpretação do conteúdo não pode mais ocorrer linearmente. Dela se demanda um trabalho de decodificação a partir dos processos primários fundamentais, $\mathrm{o}$ deslocamento e a condensação ${ }^{33}$.

Condensação e deslocamento, segundo Metz, constituem dois lados de um único movimento de mostrar e esconder. Não se colocam, portanto, como instrumentos de constituição do sentido, mas são o próprio sentido, o indício de desmascaramento de um objeto deslocado de seu estrato conceitual ordinário e combinado com outros objetos os quais lhe desvendam os significados ocultos e proibidos $^{34}$. Esses dois procedimentos - próprios ao inconsciente e à atividade onírica - deliberadamente abundavam em Münchhausen. Quando os utensílios e instrumentos expressavam emoções ou agiam como pessoas, condensavam num status impossível as condições simultâneas de sujeito e objeto. O mesmo recurso deslocava as emoções e expectativas humanas dos personagens para as coisas. Essas operações se estendiam dos personagens e seus apetrechos às relações de tempo e espaço. Os cenários de Münchhausen emulavam um mundo livre das leis ordinárias da realidade, governado por um tempo definido como kaputt, "quebrado". O que, também comungava com o domínio dos processos inconscientes. Pois esses são intemporais. Porque estão orientados pelo princípio do prazer, nem se referem a qualquer lógica cronológica, nem se pautam na realidade física ${ }^{35}$.

energia psíquica, nessa nova situação, passa por um reajuste que conecta ideias e imagens em expressões mais controladas, estabilizando-a nas formas passíveis de verificação pela experiência sensorial do sujeito no mundo externo. LAPLANCHE, Jean: PONTALIS, Jean-Bertrand. The Language of Psychoanalysis. Tradução: Donald Nicholson-Smith. Londres: Karnac Books, 1988, 33941.

$33 \mathrm{O}$ deslocamento constitui o movimento de cruzamento pelo qual uma ideia passa para outra, fazendo o sentido também deslizar de um lugar a outro. A condensação, por sua vez, produz a fusão de dois conceitos, o que desconstrói o princípio da não contradição pelo qual duas coisas diferentes jamais poderiam ser a mesma. LAPLANCHE, Jean: PONTALIS, Jean-Bertrand. The Language of Psychoanalysis. Tradução: Donald Nicholson-Smith. Londres: Karnac Books, 1988, 823, 121-3 e METZ, Christian. Psychoanalysis and Cinema: the Imaginary Signifier. Tradução: Celia Britton, Annwyl Williams, Brewster, Alfred Guzzetti. Londres: Macmillan Press, 1983, 258, 261$4,266$.

${ }^{34}$ METZ, Christian. Op. cit., 269-70.

${ }^{35}$ FREUD, Sigmund. O inconsciente in FREUD, Sigmund. Obras psicológicas completas de Sigmund Freud: Volume XIV. Tradução: José Octávio de Aguiar Abreu, Christiano Monteiro Oiticica. Rio de Janeiro: Imago, 1996, 152. 
Em Münchhausen, todas essas profusas e reiteradas representações de irracionalidade normatizavam a fantasia fílmica no âmbito do processo primário e, nesse circuito, faziam a história oscilar entre as atividades onírica e psicopática. Pois os processos primários, assinalou Freud, somente se dão a saber nessas duas condições psicológicas - os sonhos e as neuroses ${ }^{36}$. E esses estados, por sua vez, perfazem a um gênero narrativo próprio, constelado de implicações ideológicas.

Münchhausen, observaram seus críticos, tratava-se de um dos poucos filmes completamente devotados ao imaginário, ao fantástico e ao irreal oriundos do Terceiro Reich. Pertencia àquela categoria peculiar de obras narrativas que revertem os processos secundários (os quais, nos filmes narrativos, promovem uma costura dos elementos da fantasia em uma estrutura lógica), para dispor suas formas nos códigos do processo primário. Levava, assim, seu espectador a lugares estranhos, a mundos irracionais em voos rasantes na fantasia, encenando a intoxicante euforia da imaginação maximizada em seus extremos. Evolvia de uma história a outra em cenários e situações cada vez mais fabulosas. Contrastava com os pudores das demais produções do período nazista investindo numa representação de libertação do erotismo e da violência. Distanciava-se radicalmente das formas do cinema clássico, adotando os contornos do gênero das histórias fantásticas do período barroco alemão ${ }^{37}$. Sua estrutura narrativa, considerou Linda Schulte-Sasse, chegava a recuar a um protótipo até mesmo mais arcaico, As mil e uma noites. Construía, a partir dessa referência, uma fantasia em que o talento para o relato de histórias estendia o tempo de vida e espantava a morte. Münchhausen não perseguia, portanto, nenhum propósito, exceto seguir desejando. Nunca realizava qualquer desejo que não fosse o de narrar suas aventuras. Como Sheherazade, o gozo se resolvia no ato narrativo. Esse desejo de narrar não apenas recompensava o Barão pela sua renúncia aos objetos ordinários como o poder e a riqueza. Ele também escamoteava todas as necessidades que não podiam ser contidas pelas palavras. De modo que, quando encerrou o rol de suas narrativas, o Barão deixava de

\footnotetext{
36 FREUD, Sigmund. Op. cit., 192.

37 RENTSCHLER, Eric. Op. cit., 201, SCHOEPS, Karl-Heinz. Op. cit., 217-8 e SCHULTE-SASSE, Linda. Op. cit., 304.
} 
desejar. Podia então admitir sua própria mortalidade, e, enfim, entregar-se ao seu maior inimigo, o tempo ${ }^{38}$.

Ainda que categorizado por seus críticos como um filme fantástico, Münchhausen se filiava com mais precisão a uma subcategoria específica desse gênero que Todorov nomeou como maravilhoso (para a qual ofereceu justamente As mil e uma noites como paradigma). O maravilhoso difere do fantástico pelo significativo fato de que os acontecimentos da história soam extraordinários ao leitor, mas não produzem qualquer reação de estranhamento nos personagens ${ }^{39}$. Esse subgênero empresta do fantástico elementos e situações que escapam à lógica racional para os apresentar como eventos corriqueiros. Torna, assim, plausíveis ocorrências absolutamente inexplicáveis. Mas também trafega na direção oposta. Peculiarmente, investe na hipérbole, a qual, na trama, adquire um valor de medida, fazendo fenômenos ordinários parecerem sobrenaturais pelas suas dimensões. Caracteriza-se, igualmente, por um fascínio pelo exótico, mediante o que a paisagem, os habitantes e os costumes de lugares remotos, fictícios ou não, adquirem traços fabulosos. Lança mão rotineiramente de instrumentos e objetos miraculosos capazes de operar prodígios ${ }^{40}$. No mais, dentro das linhas gerais do gênero, o maravilhoso conjura um sistema de transgressões, notadamente a desconstrução do binômio sujeito/objeto, a desnormatização das relações de causa e efeito e a desetruturação da marcação de tempo. Tudo isso alinha as operações semânticas do gênero a uma variedade de experiências psíquicas, em especial a percepção psicológica infantil, a narcose e o quadro psicótico ${ }^{41}$.

O maravilhoso não determina, desse modo, apenas uma suspensão

\footnotetext{
$38 \mathrm{Um}$ aspecto que, observou Linda Schulte-Sasse, podia ser interpretado retrospectivamente como uma alegoria do próprio nazismo, que, em 1943 iniciara sua derrocada porque começava a lhe escapar a capacidade de engendrar narrativas mistificantes. SCHULTE-SASSE, Linda. Op. cit., 305-6, 315 .

39 TODOROV, Tzvetan. As estruturas narrativas. Tradução: Ligia Perrone-Moisés. São Paulo: Perspectiva, 2013, 58-9 e TODOROV, Tzvetan. Introdução à literatura fantástica. Tradução: Maria Clara Correa Castello. São Paulo: Perspectiva, 2014, 154, 156, 160.

40 TODOROV, Tzvetan. As estruturas narrativas. Tradução: Ligia Perrone-Moisés. São Paulo: Perspectiva, 2013, 59-63.

${ }^{41}$ TODOROV, Tzvetan. Introdução à literatura fantástica. Tradução: Maria Clara Correa Castello. São Paulo: Perspectiva, 2014, 128 e TODOROV, Tzvetan. As estruturas narrativas. Tradução: Ligia Perrone-Moisés. São Paulo: Perspectiva, 2013, 161.
} 
programada da lógica, nem somente convida o espectador a gozar na desordem. Enquanto gênero, ele promove um sistema lógico que organiza seus elementos para deliberadamente os dispor como desordenados, delirantes, extravagantes e irracionais. Trata-se, por conseguinte, de uma modalidade única de organização dos conteúdos. Tomando como base as operações da censura do inconsciente aos processos secundários como eles ocorrem nos sonhos e nos devaneios, constrói uma realidade imaginária baseada diretamente na linguagem do inconsciente. De modo que Münchhausen interpelava não o conteúdo manifesto dos desejos de seus espectadores, mas a latência do desejo em si mesmo, o desejo descarnado dos invólucros sem os quais remanesceria proscrito no estado de vigília consciente. O filme, por assim dizer, acessava sem subterfúgios o conteúdo proibido. Como tal, dirigia-se a sujeitos aptos a decodificá-lo por detrás da estratégia de desmascaramento. Apresentava como protagonista o homemimagem para quem nada era impossível. Promovia uma fantasia radical da masculinidade que rebatia no protagonista uma polimórfica miragem do masculino entrevisto dentro e fora da regra nazista, nomeada ora com o rótulo "o novo homem", ora com o epíteto "a personalidade fascista".

A qualificação da categoria antropológica do "novo homem" fascista marcou uma etapa fascinante do pensamento ocidental contemporâneo, porque produziu uma pletora de marcadores e indícios para descrever à distância ou $a$ posteriori o objeto ao qual as teses se propunham a elucidar. Ora convergindo, ora divergindo, os sistemas teóricos voltados à indexação do caráter, da identidade, das disposições psicológicas e das singularidades do homem engendrado pelo fascismo tomaram como ponto de partida precisamente o difuso paradigma do irracional.

Deve-se a Adorno e Horkheimer, e, com eles, os pensadores da Escola de Frankfurt, o acento original nesse nexo decisivo entre o nazismo e a irracionalidade. A partir do que a Teoria Crítica não vislumbrou nenhum sujeito próprio do fascismo apartado de um padrão de repetição compulsiva e da 
experiência de regressão vivenciada coletivamente em meio às massas. Da reprodução incessante de gestos e verbos, concluíram, esses sujeitos internalizavam irracionalidade. O fascismo era, então, uma técnica racional para induzir ao irracional ${ }^{42}$.

Essa subjetividade inexistente fora da órbita da massificação, foi, nessa mesma linha teórica, construída em torno do excesso passional como uma entidade sincrética, idealizada nos termos da fusão e da coparticipação. $O$ "novo homem", esclareceu Marcuse, pertencia a uma totalidade, o Volk, o povo, uma unidade orgânica superior a todas as demais diferenças de classe e de interesses existentes na sociedade. Era o herdeiro do binômio Blut und Boden, do sangue e do solo, modelado na imagem do camponês, vinculado às forças da terra, guardião das tradições ancestrais e ligado a uma comunidade de destino conservadora, reacionária e historicamente estática. Carregava, portanto, características intrínsecas de sua ascendência. Pelo que também encarnava a visão mística do viking sobre o qual se apôs a mentalidade da caserna prussiana para assim moldar uma forma heroica, forjada na excelência da raça. De modo que nele se combinava uma noção de heroísmo com valores abstratos como honra, moralidade, dever e renúncia. Encontrava então seu representante no homem de ação, que não habitava nenhum mundo de ideias, mas mourejava no campo de lutas. A disposição para o infortúnio passou a representar para ele a atitude honrosa que comungava os novos homens num destino universal. Tornara-se, assim, uma criatura intelectualmente inerme, que agia sem saber por quê e nunca decidia por si mesmo em favor do que dirimia seu ato. Simplesmente descredenciava o logos como mediador dos seus gestos e entravam em ação perseguindo as emoções de um pathos furioso ${ }^{43}$.

\footnotetext{
42 O fascismo, acrescentaram Adorno e Horkheimer, dispunha processos irracionais, inconscientes e regressivos aos extratos da população excluídos dos meios de representação política, cuja frustração os tornara propensos a sentimentos mesquinhos e ilógicos. De modo que triunfou, nesse ponto de vista, porque tomou os homens massificados pelo que eram - indivíduos destituídos de autonomia e de espontaneidade, incógnitos numa sociedade de massas que destruiu sua potência criativa. ADORNO, Theodor W.; HOKHEIMER, Max. Teoria freudiana e o padrão da propaganda fascista in ADORNO, Theodor W. Ensaios sobre psicologia social e psicanálise. Tradução: Verlaine Freitas. São Paulo: Editora Unesp, 2015, 184-6.

43 MARCUSE, Herbert. Negations: Essays in Critical Theory. Londres: MayFly, 2009, 2, 4, 15-7, 18, $19,20,23-4$.
} 
Marcuse atribuía o elemento irracional da personalidade do homem fascista à ênfase na ação. Do que derivava da sua irracionalidade o relativismo ético, o descolamento de qualquer programa de princípios, a volatilidade da retórica que lhe comovia, a inconsistência da sua ideologia e a identidade flutuante dos movimentos políticos aos quais ele aderia ${ }^{44}$. No que foi secundado por Hannah Arendt que, de sua parte, identificou na guerra imperialista e racial nazista não uma mera atualização da Realpolitik europeia, mas a formulação de um conceito de dominação sem precedentes e sem suporte na própria realidade humana. $\mathrm{O}$ que implicava seus sujeitos não no domínio da crueldade como um fim, mas como resultado de uma completa desconsideração pelas consequências dos atos. Daí, os nazistas não perseguiam seus próprios interesses e desprezavam qualquer razão utilitária. Curvaram-se a um idealismo pervertido, baseado na fé em um mundo de ficção no qual, a despeito dos fatos verídicos, somente era dado como verdadeiro aquilo que interessava ao Partido e ao movimento ${ }^{45}$.

O predicado "irracional", admitiram Adorno e Horkheimer, tornou-se, então, vago demais para justificar um fenômeno psicológico tão complexo quanto o fascismo. Essa irracionalidade, concluíram, era, pois, a face visível de uma patologia social, a exteriorização dos conteúdos neuróticos entre pessoas que partilhavam das mesmas disposições. Do que acentuaram o elemento da destrutividade como fundamento da psicologia de massa fascista e seu elemento retórico mais eficiente ${ }^{46}$. E essa patológica predisposição à destruição, poderia acrescentar Victor Klemperer resultava, por sua vez, de uma deficiência cognitiva. O sujeito sistematicamente exposto a uma retórica baseada no ódio, na violência e na impotência processou uma mutação em seu caráter. "O nazismo”, defendia Klemperer, "se embrenhou na carne e no sangue das massas por meio de palavras, expressões e frases impostas pela repetição milhares de vezes, e

\footnotetext{
${ }^{44}$ MARCUSE, Herbert. Reason and Revolution: Hegel and the Riseof Social Theory. Nova York: Humanity Books, 1999, 405-8.

45 ARENDT, Hannah. The Origins of Totalitarism. Nova York: Harcourt, 1997, 417.

${ }^{46}$ ADORNO, Theodor W.: HORKHEIMER, Max. Teoria freudiana e padrão da propaganda fascista in ADORNO, Theodor W. Ensaios sobre psicologia social e psicanálise. Tradução: Verlaine Freitas. São Paulo: Editora Unesp, 2015, 143-4, 152.
} 
aceitas inconsciente e mecanicamente" 47 . Esse déficit cognitivo, assentia Hannah Arendt, tornava então o homem da massa, incapaz de discernir um juízo autêntico de um discurso fraudulento ${ }^{48}$. Tomado pela sua crença, o nazista remanescia impermeável às impressões da experiência efetiva ou aos argumentos da razão. De modo que, de acordo com Arendt, a identificação com o movimento implicava na erradicação do contraditório e numa imersão no conformismo pela erosão da habilidade reflexiva ${ }^{49}$.

Essa reversão, contudo, somente se processou ao preço de uma transformação na sua percepção da realidade. Pois as massas nas quais esses sujeitos se refugiavam, almejam precisamente se evadir do real. Sendo compostas pelos desesperançados, pelos que decaíram socialmente e pelos excluídos dos sistemas de representação, elas se revoltavam contra a realidade. Rejeitavam-na pela sua qualidade anárquica e pela arbitrariedade das formas de existência social, procurando conforto nas elaborações fantasiosas da doutrina ${ }^{50}$.

A Hannah Arendt deve se atribuir o mérito de ter reconhecido a extraordinária maleabilidade da psique do homem totalizado, pelo que sua personalidade perdia a continuidade e podia, assim, adequar suas convicções a qualquer situação e contra qualquer crítica ${ }^{51}$. O que a obrigou, mais tarde, a levar em conta que que o fascista alemão não definia a si mesmo de modo algum como um fanático pervertido, nem como um aventureiro ou um criminoso, mas sim, como um burguês respeitável, um pater famílias preocupado em assegurar um futuro consistente aos seus filhos. Atribulado com a situação de adversidade econômica, esse bom burguês se dispôs a sacrificar seu discernimento e a se degradar, fazendo de si um colaborador. Justificava-se com a ideia de que o bemestar social e econômico de sua família dependia disso. Assim, isentava a si mesmo da culpa pelos seus atos. Em nome da respeitabilidade, sacrificou sem

\footnotetext{
47 KLEMPERER, Victor. LTI: a linguagem do Terceiro Reich. Tradução: Miriam Bettina Paulina Oelsner. Rio de Janeiro: Contraponto, 2009, 55.

48 ARENDT, Hannah. À mesa com Hitler in ARENDT, Hannah. Compreender: formação, exílio e totalitarismo (ensaios) 1930-54. Tradução: Denise Bottman. São Paulo: Companhia das Letras. Belo Horizonte: Editora UFMG, 2008, 315.

${ }^{49}$ ARENDT, Hannah. The Origins of Totalitarism. Nova York: Harcourt, 1997, 308,

${ }^{50}$ ARENDT, Hannah. Op. cit., 352.

${ }^{51}$ ARENDT, Hannah. Op. cit., 306.
} 
pestanejar sua responsabilidade ${ }^{52}$.

Dentre os exegetas coevos aos acontecimentos, Wilhelm Reich foi quem primeiramente contrariou todas as tendências que, logo de início, interpretaram o advento do fascismo como o resultado de um trabalho concertado de ilusão das massas. Produziu uma chave original para elucidação do fenômeno ao assinalálo como um grave desarranjo da libido. O que firmava o caráter fascista, era, ao seu ver, não uma cena política propícia, mas a estrutura funcional da família patriarcal que obstruía a realização da sexualidade por seus meios naturais de gratificação. A debilitação da sexualidade, prosseguiu Reich, não resultava na sublimação, mas no declínio da autoconfiança, o que, por sua vez, ensejava o embrutecimento do erotismo e o enrijecimento do caráter. Esse controle permanente sobre o desejo sexual exigia, por isso, mecanismos de manutenção da repressão que evolviam para noções abstratas como honra, dever, bravura e autocontrole. Consequentemente, esses homens viviam assombrados por um terror mortal de tudo que solicitava deles vitalidade e liberdade ${ }^{53}$. Reich, desse modo, implicou o fascismo no campo do desejo (um desejo de não desejar) e, somente assim, convergiu com o postulado de Adorno, para quem o nazismo chegou quando as massas mais o desejaram ${ }^{54}$.

Porque então exprimia uma visão coletivizada do desejo recalcado, o nazismo, observou Susan Sontag, comportava um sedimento de assexualidade que atravessava os corpos belos e saudáveis, mas esvaídos de libido na sua dupla servidão, ao superego e ao Führer. Evocava, assim, uma longeva visão da beleza: simples, figurativa, subtraída de qualquer intelectualidade, destituída de formas complexas que dificultassem a aproximação. Ensejou um erotismo petrificado e teatralizado nas formações de massa para mitigar as ansiedades de uma

\footnotetext{
52 Arendt derivou disso o conceito de banalidade do mal, ou seja, o mal vivido como uma experiência desenraizada da razão, que não perseguia objetivos malignos, mas apenas resultava de uma ação instrumental onde a consciência foi completamente expropriada. ARENDT, Hannah. Guilty and Universal Responsibility in BAEHR, Peter (ed.). The Portable Hannah Arendt. Londres: Penguin, 2000. 196 e ARENDT, Hannah. Guilty and Universal Responsibility in BAEHR, Peter (ed.). The Portable Hannah Arendt. Londres: Penguin, 2000, 196.

${ }^{53}$ REICH, Wilhelm. The Mass Psychology of Fascism. Nova York: Farrar, Straus and Giroux, 1985, 23, 28, 30-1, 34, 48, 54-5.

54 THEWELEIT, Klaus. Male Fantasies: Volume 1:Women, Floods, Bodies, History. Tradução: Stephen Conway, Erica Carter, Chris Turner. Minneapolis: University of Minnesota Press, 2010, 218.
} 
sociedade sexualmente reprimida. Sontag concluiu que, esquadrinhando os limites da encenação, o fascismo descambava, ao fim, no sadismo. Pois ambos partilhavam de um mesmo esquema cênico. Os dois se especializaram nos vestuários, nos ritos complicados e nas coreografias do desejo reprimido. Buscavam uma experiência erótica selvagem confortavelmente acomodada nos liames seguros da dissimulação. Aqui e ali, a estética investia no refreamento das forças vitais, sobrepondo-lhes movimentos crispados e ríspidos do que resultava um amálgama do kitsch com o camp para promoção de uma (bela) forma à pulsão de morte 55 .

Pela via da pulsão de morte, inferiu Adorno, o sadismo do caráter fascista convergia com sua homossexualidade reprimida. Pois, à guisa de Freud, nas obras da civilização, Adorno vislumbrou produtos de um amor-ódio por aquilo do corpo que foi disciplinado pela dominação social. Nos homicidas que os sistemas de poder empregam para sustentar o terror, sem o qual a dominação social não existiria, essa relação de amor e ódio se manifestava sem mediações. Nesse caráter empedernido, frio, rígido, predisposto a devolver como gozo a

\footnotetext{
$55 \mathrm{O}$ instinto de morte foi aquilo que Freud encontrou quando lançou seu olhar para além do princípio do prazer. Localizou ali uma compulsão à repetição mais primitivamente enraizada na inconsciência do que a energia libidinal, um remanescente de memórias traumáticas do momento em que os impulsos instintuais foram reprimidos, uma latência mal sepultada, sempre prestes a irromper como presença. Pelo que, acrescentou Laplanche, a pulsão de morte não demarcava um campo de conflito, pois se tratava do próprio conflito consubstanciado, a manifestação externa do princípio de discórdia e desunião com o mundo exterior. A pulsão de morte não se definia, portanto, como uma tendência à morbidez, mas, sim, pela cooptação da libido para fins alheios ao Eros. Daí, ela não contém uma energia própria, um destrudo que replicaria no campo psíquico a figura da libido. Sua energia, esclareceu Laplanche, é a própria libido. Coerentemente, observou Elisabeth Roudinesco, enquanto um sistema voltado a uma disciplina libidinal do desejo, o nazismo promoveu um regime de estatização das perversões privadas, instituindo ambientes propícios a diferentes modalidades de desenraizamento da pulsão de morte. Assim, para homens como Rudolph Höß, normatizou práticas que revertiam os processos de sublimação: destravoulhes as comportas do prazer sádico que atribuía às vítimas o desejo de serem seviciadas até a morte, um raciocínio que instruiu os funcionários de Auschwitz como meros executores da vontade autopunitiva dos encarcerados. E mesmo nos casos como o de Adolf Eichmann, em que nenhuma patologia psíquica pudesse se discernir, o nazismo produziu sistemas de satisfação sádica, ritualizando, teatralizando e automatizando os atos de destruição de vidas indesejáveis ao regime. FREUD, Sigmund. Além do princípio do prazer, in Obras psicológicas completas de Sigmund Freud Volume XVIII. Tradução: José Octávio de Aguiar Abreu Christiano Monteiro Oiticica. Rio de Janeiro: Imago, 1996, 28-33, LAPLANCHE, Jean. Vie et mort em $p$ sychanalyse. Paris. Flammarion, 2001, 185, ROUDINESCO, Elisabeth. A parte obscura de nós mesmos: uma história dos perversos. Tradução: André Telles. Rio de Janeiro: Zahar, 2008, 128-9, 125, 144, 154, 161-2 e SONTAG, Susan. Fascinante Fascismo in Sob o signo de Saturno. Tradução Ana Maria Capovilla. L\&PM, 1980, 73, 801.
} 
mesma violência que recebeu como punição, Adorno identificou o protótipo do homem de sua época, o tough guy, o he-man, o sádico que acolhera masoquistamente a estereotipia da masculinidade e, com ela, justificara a si próprio sua devoção à repressão. Tais homens efetuam seu rancor pelos seus corpos reificados, descarregando-o numa fúria cega sobre seus objetos. Do que Adorno concluiu que essa hostilidade dirigida ao outro reforçava socialmente, pela prática organizada do homicídio, laços homossexuais e paranoicos. O transbordamento de tamanha virilidade era, ao seu ver, o sintoma de uma homossexualidade reprimida, uma desintegração do desejo que se reintegrava, então, na ausência de felicidade. Essa personalidade polarizada pela infelicidade necessitava dos pacíficos para infligir contra eles a violência defensiva com a qual negava sua própria afeminação, totalizando à sua identidade somente aquilo que escamoteava o que ela continha de afeminado. Do que Adorno conclui que "totalidade e homossexualidade se ajustam" 56.

Não sendo homoerótica, havia na estridência da masculinidade nazista um elemento que o correspondente Curzio Malaparte descreveu como uma "qualidade feminina". Reconheceu esse conteúdo in loco nas atrocidades cometidas na Polônia, onde concluiu que ele servia como um elo de integração social para homens que viviam entre o medo e a crueldade. Pois, ao seu ver, os

\footnotetext{
56 A homossexualidade consistiu, para além de qualquer dúvida, uma das preocupações mais persistentes do nazismo, levada a extremos que atestavam a permanente tensão defensiva do caráter fascista em relação ao seu ideal de masculino. A política do Terceiro Reich em relação aos homossexuais era radicalmente voltada à meta exterminadora. Contra eles, artigos do código penal foram reforçados com decretos adicionais que implicavam em maior tempo de encarceramento e na transferência posterior, por períodos indeterminados, a campos de concentração. Durante a guerra, a cada ano, em média 2.300 homossexuais foram encaminhados a Sachsenhhausen e Dachau onde recebiam um severo tratamento baseado em trabalhos forçados com a finalidade de seleção dos mais masculinos. O bloco homossexual tornou-se um dos grupos preferenciais para a prática de abatimento a tiros em encenações de tentativas de fuga. Não há cálculo do número de prisioneiros dessa categoria nos campos, que oscila entre cinco a quinze mil, do que se estima que metade deles ali pereceu. ADORNO, Theodor W. Interesse pelo corpo in ADORNO, Theodor W.: HORKHEIMER, Max. Dialética do Esclarecimento. Tradução: Guido Antonio de Almeida. Rio de Janeiro: Zahar, 1985, 193 e ADORNO, Theodor W. Minima Moralia: reflexões a partir da vida lesada. Tradução: Gabriel Cohn. Rio de Janeiro: Beco do Azougue, 2008, 41-2, CHAPOUT, Joahann. Virilidade Fascista in CORBIN, Jean-Jacques Courtine; VIGARELLO, George. História da Virilidade 3: a Virilidade em crise - séculos XX-XXI. Tradução: Noéli Correia de Mello Sobrinho, Thiago de Abreu e Lima Florênciao. Petrópolis e Rio de Janeiro: Vozes, 2013, 339 40 e EVANS, Richard J. The Third Reich at War: How the Nazis Led Germany from Conquest to Disaster. Nova York: Penguin, 2009, 537 e LONGERICH, Peter. Heinrich Himmler. Tradução: Jeremy Noakes, Lesley Sharpe. Oxford: Oxford University Press, 2012, 234-40, 537, 595-6.
} 
alemães padeciam de um terror patológico, não de homens armados, mas dos desprotegidos. "Medo dos oprimidos, dos indefesos, dos fracos, dos doentes: medo de mulheres e de crianças, medo dos judeus". Por mais que tentassem esconder esse vergonhoso sentimento, ele aflorava nos seus gestos. Tamanho era esse terror que não conseguiam se evadir dele. Para provar a si mesmos que nada temiam, então, expunham-se à violência, à fome e ao morticínio com uma mórbida paixão que rescendia rancor, inveja, frustração e uma vibrante disposição pela autodegradação ${ }^{57}$. Então, porque temiam os objetos, imaginando neles seus próprios anseios destrutivos, os fascistas se dedicavam diligentemente ao seu extermínio, do que passavam a ocupar uma topologia impossível, comportando-se, ao mesmo tempo como paranoicos e sádicos ${ }^{58}$.

Para explicar a violência nazista fora do âmbito da perversão, o fenômeno terminaria, por conseguinte, incidindo no território das demências profundas. Jung, por esse expediente, viria então a atribuir à psicopatia de um só homem, Hitler, o contágio de todo meio social. Transladou o fascismo alemão como um

\footnotetext{
${ }^{57}$ MALAPARTE, Curzio. Kaputt. Tradução: Cesare Foligno. Nova York: Nyrb, 2005, 91-2.

58 Freud sugeriu que tanto na paranoia persecutória quanto na homossexualidade há um desvio e uma exasperação na orientação dos afetos hostis. Ambas coincidem no esforço de repressão de impulsos agressivos que, não encontrando outros meios de satisfação, orientam-se de volta ao objeto ao qual o sujeito devotava seus sentimentos. O homossexual experimenta amor pelo pai que odiou e o paranoico sente como ódio o que outrora foi amor. O que não implica no alinhamento da homossexualidade reprimida, da paranoia e do sadismo num mesmo denominador. Definir uma personalidade simultaneamente como sádica e paranoica interrompe a análise num impasse, pois os dois estados não podem ocupar o mesmo local da significação. Ainda que ambos sejam capturados na ordem simbólica e trabalhem freneticamente a serviço do Outro, essa relação difere no destino dado aos objetos. O sádico, na teoria freudiana, libertou o componente destrutivo do id e o dirigiu aos objetos. Do que Lacan derivou que ele se colocou como instrumento de uma vontade externa, o próprio objeto a serviço do Outro. Por isso, sua atividade destruidora não almeja a autossatisfação, mas o gozo do Outro. Faz de si o executor do flagelo porque assume o seu desejo como idêntico ao da ordem simbólica. O paranoico, ao contrário, identificou no Outro uma ameaça, um perigo, o portador de catástrofes que deve ser detido. De modo que, ao contrário do sádico, seu empenho se volta a interceptar o gozo do Outro. FREUD, Sigmund. Alguns mecanismos neuróticos no ciúme, na paranoia e no homossexualismo in FREUD, Sigmund. Obras psicológicas completas de Sigmund Freud: Volume XVIII. Tradução: José Octávio de Aguiar Abreu, Christian Monteiro Oiticica. Rio de Janeiro. Imago, 1996, 240, FREUD, Sigmund. O ego e o id in FREUD, Sigmund. Obras psicológicas completas de Sigmund Freud: Volume XIX. Tradução: José Octávio de Aguiar Abreu. Rio de Janeiro: Imago, 1996, 68, LACAN, Jacques. O seminário Livro 10: a angústia. Tradução: Vera Ribeiro. Rio de Janeiro: Zahar, 2005, 61, 166-7, MILLER, Jacques-Allain. Percurso de Lacan: uma introdução. Tradução: Ari Roitman. Rio de Janeiro: Zahar, 1987, 199 e ZIZEK, Slavoj. Looking Awry: an Introduction to Jacques Lacan through Popular Culture. Cambridge e Massachusetts: October Books/ Massachusetts Institute of Technology, 1991, 108, 179.
} 
prodigioso caso de possessão psíquica que depravou toda a sociedade ${ }^{59}$. Diagnosticou nessa doença social a irrupção de conteúdos primitivos recalcados no inconsciente que, uma vez libertados, passaram a operar de forma autônoma, submergindo os sujeitos nas suas imagens (na teoria junguiana, esses conteúdos se denominavam arquétipos ${ }^{60}$. Reconheceu, daí, na sanha nazista, a mal disfarçada renovação do culto de um desaparecido deus germânico, Wotan, o abissal homem-fera, o lutador errante e vingativo, o tempestuoso deus da carnificina, o açodador cruel ${ }^{61}$.

$\mathrm{Na}$ turbulência frenética da massa fascista, da qual Jung extraiu um vislumbre de um homem mitológico, Gramsci, outro analista contemporâneo aos fatos, diagnosticou não um acontecimento mítico, mas, contrariamente, apenas o triunfo da mediocridade mediatizada. Descreveu sumariamente o homem

59 JUNG, Carl Gustav. A luta contra as sombras in JUNG, Carl Gustav. Aspectos do drama moderno. Tradução: Lúcia Mathel Endlich Orth. Petrópolis: Vozes, 2012 e JUNG, Carl Gustav. Wotan in JUNG, Carl Gustav. Aspectos do drama moderno. Tradução: Lúcia Mathel Endlich Orth. Petrópolis: Vozes, 2012, 12-8.

${ }^{60}$ Arquétipos constituem um depósito de formas psíquicas invariantes, enfeixadas no substrato mais profundo da mente humana, o inconsciente coletivo. Detêm um poder compensatório sobre a consciência racional quando essa se impõe demasiadamente na estrutura psicológica do sujeito. $\mathrm{O}$ arquétipo atua como uma sombra do coletivo, uma condensação psíquica atemporal e universal, dissolvendo o juízo do sujeito e o lançando no êxtase da revelação ou da aniquilação. Traga o homem para dento de sua imensidão, obsedando-o emocionalmente, destruindo as barreiras defensivas da sua identidade. Torna-o propenso às invasões da sugestão coletivizada na massa. Se um arquétipo não se abaliza por uma via consciente, não provê garantia nenhuma de que se realizará por meios benéficos. Sob sua ascendência, o sujeito se torna, por assim dizer, possuído por forças impessoais e não mais responde por seus atos. JUNG, Carl Gustav. Os arquétipos e o inconsciente coletivo. Tradução: Maria Luiza Appy, Dora Mariana R. Ferreira da Silva. Petrópolis: Vozes, 2014, 11-81.

${ }^{61}$ Uma divindade da guerra e um psicopompo identificado junto aos romanos ora com Marte, ora com Mercúrio, celebrava-se Wotan às margens do Reno no século I, de onde seu culto se espalhou entre as populações do norte. Alcançou, do século II ao IV, a Dinamarca e a Suécia. Atravessou mais tarde o Mar do Norte. Desembarcou na Bretanha onde lhe atribuíram a ancestralidade de várias dinastias reais pagãs. Assumiu, nesse trajeto, diferentes nomeações (Wodan, Woden). A ele se devotou o quarto dia da semana, Wednesday, o dia de Woden. Entre as tribos que o adoravam - os Heruli, os Godos, os Cimbri, os Hemundari e os Chatti - violentos sacrifícios humanos desempenhavam papel primordial nos ritos de apaziguamento. Os Heruli lhe imolavam os prisioneiros de guerra em rituais duplos de esquartejamento e expiação no fogo. Os sacerdotes címbrios dependuravam as vítimas em galhos de árvores e ali as degolavam. Uma modalidade mais extrema de homenagem ocorria junto aos Hermundari e os Chatti, os quais votavam à destruição todo butim recolhido do inimigo. Trucidavam prisioneiros, animais, armas, armaduras, vestimentas, ferramentas e cerâmicas. Devolvendo-os como empenho pela vitória alcançada, os corpos e os despojos ofertados serviam para aplacar a ira do deus solicitada antes da batalha. DAVIDSON, H. R. Ellis. Gods and Myths of Northern Europe. Londres: Penguin Books, 1990, 54-6, 147-8 e JUNG, Carl Gustav. Wotan in JUNG, Carl Gustav. Aspectos do drama moderno. Tradução: Lúcia Mathel Endlich Orth. Petrópolis: Vozes, 2012, 19-27. 
inclinado ao fascismo como o pequeno burguês que macaqueia a luta da classe operária com estridência, mas sem consistência. Agrupou-o numa "classe de falastrões, de céticos, de corruptos", um "povo de macacos" especializado no cretinismo, que, com suas manifestações, produzia manchetes jornalísticas, mas jamais escrevia a história, e que, tomado de desencanto, convenceu-se de que que a solução da crise política deveria vir de fora da ação política, de preferência com um gesto arbitrário de autoritarismo ${ }^{62}$.

Um não-sujeito irracionalmente inclinado à destruição em decorrência de frustrações sociais tão profundas que comprometeram seu juízo cognitivo; o pequeno burguês que resolvia seus conflitos de consciência ora se mantendo em permanente estado de denegação, ora produzindo simulacros barulhentos da luta de classes; o homem transtornado sexualmente, cuja libido enrijecida vacilava entre a perversão sádica e a homossexualidade reprimida; e, por fim, um demente paranoico possuído por conteúdos psíquicos que subitamente ganharam vida e fizeram dele um instrumento de sua maligna vontade. O que todas essas interpretações produzem não é o retrato do homem nazista, mas o reconhecimento de que não houve um, mas muitos homens que viveram à sombra do nazismo - a latitude de sua variedade caracteriológica justificava esse repertório de teorias que, com maior ou menor consistência, pretendia sistematizar uma visão de um tipo social e de um ator histórico.

Fossem quais fossem seus contornos, contudo, nenhuma dessas variedades de masculino encontravam ressonância na luminosa figura do Barão. Dele não se podia dizer que era, por nenhum meio, um homem inibido sexualmente, um homossexual recalcado, um sádico, um oligofrênico ou um paranoico. Oferecia ao público o oposto disso. Ao invés da segurança da monogamia heterossexual burguesa, providenciava as mais variadas oportunidades para experimentar a suprema felicidade do amor livre junto a mulheres deslumbrantes e desinibidas.

${ }^{2}$ GRAMSCI, Antonio. O leitor de Gramsci: escritos escolhidos 1916-1935/ Carlos Eduardo Coutinho (org.). Rio de Janeiro: Civilização Brasileira, 2011, 86-8. 
Contestava com veemência a idealizada exaltação da terra natal para vagabundear onde o desterro o levasse. Destituído de qualquer coisa parecida com um superego, observou Linda Schulte-Sasse, o Barão somente atendia às exigências do seu narcisismo que parecia lhe oferecer as respostas mais adequadas às demandas do mundo tresloucado em que habitava. No lugar da renúncia e do comedimento, despendia sua energia para produzir mais excessos, mais erotismo, menos realismo e mais surrealismo. Münchhausen, concluiu Schulte-Sassse, vivia em estado lisérgico ${ }^{63}$. Por conseguinte, ao invés das teorias do "novo homem" e da "personalidade fascista", somente um sistema que alinha a imagem da masculinidade ao narcisismo, à psicodelia e à incontinência do desejo pode explicar o persistente carisma do Barão junto ao seu público.

$\mathrm{Na}$ desconcertante multiplicidade de expressões da masculinidade sob a regra fascista, subjazia um narcisismo ferido, traumatizado pela derrota na Primeira Guerra Mundial, reagindo contra as limitações do princípio da realidade, multiplicando fisionomias, mas fixado em si mesmo. Essa reação defensiva, por isso, mantinha o homem alemão numa suspensão de formas que vacilavam diante de si. E o cinema viria a ser um receptáculo imaginário para articular fantasias nas quais mesmo os semblantes desviantes podiam encontrar uma via de reintegração à nova ordem. Nesse domínio franqueado pelo narcisismo, o Barão comungava com o nazismo. Pois o que Münchhausen tematizava era, fundamentalmente, um anseio pelo ilimitado. Seu protagonista somente coincidia com uma personalidade ou um caráter passível de se apor o rótulo "fascista" pelos ritos que faziam dele uma criatura sem medidas, contornos ou fins. Havia, no filme, um constante movimento pelo qual as fronteiras se dissipavam e, assim, nada se interpunha ao movimento expansivo do Barão. Nesse sentido, Münchhausen era um curioso filme onde não havia conflitos, apenas obstáculos - e esses não persistiam por muito tempo.

Significativamente, o primeiro óbice a desaparecer do mundo do Barão era a figura paterna (ele próprio um consumado devasso revolvendo suas concupiscentes memórias ao filho). O velho Barão entrava e saía da história sem

${ }^{63}$ SCHULTE-SASSE, Linda. Op. cit., 304. 
produzir nenhum compromisso parental junto ao jovem Münchhausen e, do vácuo de sua ausência, emergiam subsequentemente personificações cada vez mais caricaturais da autoridade.

O desaparecimento do pai, no nível da fantasia, sugere o desvanecimento da interposição ao desejo. Pois a função paterna consiste precisamente em fornecer um escudo protetor contra seu transbordamento, notadamente, no que concerne ao desejo do filho de se juntar à mãe ${ }^{64}$. E nem mesmo essa discriminação, contudo, aplicava-se sem reservas ao nazismo. Ainda que que nele se vislumbre um universo sem obstáculos orientado para franquear a reunião do filho na mãe (do que se cunhou a expressão Blut und Boden e toda simbologia em torno da natureza e da raça) numa fusão livre do pai, o nazismo foi um movimento de homens que nasciam de si mesmos. Klaus Theweleit identificou no caráter fascista um desejo latente tanto de destruir a autoridade do pai quanto a fruição junto à mãe, um anseio formulado num imaginário voltado à visão de uma terra arrasada e calcinada. De modo que o homem predisposto ao fascismo tanto rejeitou o a lei do pai quanto excluiu o gozo na mãe 65 .

Esse desarranjo da função parental na sociedade alemã era um problema que remontava à época weimariana. A partir dele, Peter Gay elucidou os fenômenos sociais mais relevantes que, periodicamente, sacudiam a República: a inexplicável guerra de socialistas contra socialistas, a perpétua desordem social, as crises parlamentares, a violência paramilitar, a ascensão da casta dos demagogos, as provocações das vanguardas e a transformação da política num misto de caricatura e espetáculo66. Se, como queria Lacan, "o Nome do Pai cria a função do pai" 67, se há um momento em que o símbolo constitui a realidade e se a sociedade se validou à sombra mítica do patriarca martirizado, o sintoma mais característico da República de Weimar foi, então, a ruptura do pacto social numa

\footnotetext{
${ }^{64}$ LACAN, Jacques. O seminário Livro 6: o desejo e sua interpretação. Tradução: Claudia Berliner. Rio de Janeiro: Zahar, 2016, 133.

65 THEWELEIT, Klaus. Male Fantasies: Volume 2: Psychoanalyzing the White Terror. Tradução: Stephen Conway, Erica Carter, Chris Turner. Minneapolis: University of Minnesota Press, 2010, XXI.

${ }^{66}$ GAY, Peter, A cultura de Weimar. Tradução: Laura Lúcia da Costa Braga. Rio de Janeiro: Paz e Terra, 1978, 24-36, 90

${ }^{67}$ LACAN, Jacques Des Noms-du-Père. Paris: Éditions du Seuil: 2005, 55.
} 
insurreição da Kultur conta a Zivilisation, do ego contra o superego, do homem contra a Lei simbólica, do filho contra o pai. Segundo Peter Gay, "seria simplista interpretar a Revolução de novembro como uma coisa apenas, mas ela foi também e, significativamente, uma rebelião contra a autoridade paterna" 68 .

Na Alemanha do século XX, a disputa de gerações, consequentemente, adquiriu uma coloração política peculiar. Tornou-se um dos dínamos da história nacional na medida em que nenhuma luta de classes alterou as estruturas socioeconômicas do país ao final da Primeira Guerra e, mais tarde, na derrocada da República. Klaus Theweleit identificou no fascismo uma forma de "filiarquia", um movimento que explodiu entre filhos que combatiam no front da Primeira Guerra Mundial, para os quais o patriarcado tradicional havia fracassado ${ }^{69}$.

A complexidade histórica do movimento nacional-socialista, de sua origem em 1922 até sua consolidação como regime político, não permite, decerto, reduzilo ao horizonte de uma permanente revolta geracional. Não obstante, o primeiro e mais significativo impulso para instauração e fortalecimento do regime partiu da juventude alemã. $O$ fascismo apelava aos jovens e esses proveram uma consistente base social de apoio e sustentação para o governo hitlerista. Nos anos que antecederam a instauração do regime, os militantes nazistas eram predominantemente rapazes solteiros com formação militar. À medida que se estabeleceram no poder, o caráter prevalentemente juvenil e masculino foi sustentado pela perpetuação das violentas organizações paramilitares, encampadas pelo Partido e suas instituições. Mais tarde, seriam os estudantes que, nas universidades, organizariam campanhas contra os professores indesejáveis, arranjando massivos protestos e integrando esquadrões de depredação. Em maio de 1933, a juventude universitária encabeçou o "Ato contra o Espírito Anti-alemão" em dezenove cidades, do qual resultou a longeva memória das piras flamejantes onde arderam os livros de Marx, Mann, Freud, Remarque e tantos outros $^{70}$. O que, daí em diante, firmou uma relação de

\footnotetext{
${ }^{68}$ GAY, Peter, Op. cit., 133.

${ }^{69}$ THEWELEIT, Klaus. Male Fantasies: Volume 1:Women, Floods, Bodies, History. Tradução: Stephen Conway, Erica Carter, Chris Turner. Minneapolis: University of Minnesota Press, 2010, 107-8.

${ }^{70}$ EVANS, Richard J. The Coming of the Third Reich. Nova York, Londres: Penguin, 2003, 426-9 e
} 
dependência do regime com sucessivas gerações de rapazes para manter o ímpeto de um movimento político baseado na presunção de que a renovação nacional se sustentava a partir do espírito jovem da nação ${ }^{71}$.

A estabilização de um governo cuja plataforma política incluía um arrojado programa de remilitarização e um projeto de rápida expansão imperialista dependia do suporte da juventude. Por isso, o regime abriu várias frentes de doutrinação juvenil. Reconhecendo na família um obstáculo à totalização dos meninos, o nazismo promoveu uma série de medidas regimentais voltadas à fragilização dos laços de intimidade doméstica e à transferência das afeições parentais ao Estado, notadamente mediante a HJ, a Juventude Hitlerista ${ }^{72}$. Como a participação na $\mathrm{HJ}$ aguçava seus sentimentos de autoestima, alguns adolescentes vieram a se tornar rudes e arrogantes no âmbito doméstico. Em casos mais concretos de dissenção ideológica, os meninos podiam ser encorajados a denunciar seus pais, servindo como monitores do governo na

MANN, Michael. Fascistas. Tradução: Clóvis Marques. Record, 2008, 212.

${ }^{71}$ A dotação que firmou a Alemanha como um "país jovem" constituía uma noção consagrada quando o nazismo a recuperou para seus próprios fins. A ideia de que o Estado alemão chegara tardiamente à Europa como a mais nova nação continental gozava de imenso prestígio entre os pangermanistas e, matizada com seus preconceitos de raça, produziu resultados ideológicos portentosos. "Os povos germânicos ainda jovens estão em perfeitas condições de criar novas formas de cultura e este futuro ainda jaz no escuro do inconsciente de cada indivíduo como germe carregado de energia, capaz de transformar-se em chama vigorosa", declarou Jung em 1934. Na presunção de que essa potente linhagem racial aportava a ensolarada forma da contemporaneidade, Jung atualizava para a época atual uma tradição intelectual que associava a Alemanha à imagem renovada da masculinidade e da juventude europeia. Tais ideias eram, nessa época, quase tão antigas quanto a unificação alemã no século XIX. Remontava às teses de Gobineau que divisava a Alemanha como habitat de uma masculina nação de conquistadores, a qual trazia consigo a perpétua semente da renovação. GOBINEAU, Arthur de. The Inequality of Human Races. Londres: William Heinemann, 1915 (versão digitalizada pelo Internet Archive com fundos da University of North Carolina at Chapel Hill, 2011), 87 e JUNG, Carl Gustav. A situação atual da psicoterapia in JUNG, Carl Gustav. Civilização em transição. Tradução: Lúcia Mathel Endlich Orth. Petrópolis: Vozes, 2013, 175-6.

72 A Lei do Serviço Laboral de junho de 1935 determinou seis meses de trabalhos compulsórios para rapazes entre 18 e 35 anos com vista à os imbuir do espírito do nacional-socialismo. A partir de 1935, o alistamento no serviço militar passou a ser obrigatório pelo que as academias de treinamento de soldados voltaram a funcionar como escolas da masculinidade. E, em março de 1939, a participação na Juventude Hitlerista se tornou compulsória. Hester Vaizek, não obstante, identificou uma série de instâncias que tornaram todas essas medidas ineficazes. Nas escolas e na HJ, as crianças repetiam de cor os refrães do Partido, muitas delas sem os alcançar em sua plenitude e outras sem aderir a eles entusiasticamente. De modo geral, elas encaravam as atividades institucionais como algo enfadonho. Toleravam as preleções doutrinárias para desfrutarem das demais ações coletivas (acampamentos, esportes e jogos): frequentavam a HJ não como uma escola de edificação política, mas um clube desportivo. VAIZEY, Hester. Surviving Hitler's War: Family Life in Germany, 1939-48. Hampshire: Palgrave Macmillam, 2010, 23-5, 28. 
esfera privada. Desse modo, o poder dos adolescentes desequilibrava o balanço das relações domésticas. Ainda que em muitos casos, não necessariamente era a fixação da doutrina que predispunha o antagonismo dos filhos contra os pais, mas o típico conflito de gerações, o nazismo tornava as dissenções mais evidente pelo fortalecimento da posição social dos jovens ${ }^{73}$.

O regime, assim, operou duplamente para a desestruturação familiar. Klaus Theweleit observou que o fascismo não se opôs apenas à autoridade paterna, mas, igualmente, laborou para desconstituir a fixação materna. Do ponto de vista de Theweleit, a trajetória edípica delineada por Freud, que principiava na renúncia à mãe e se encerrava na transcendência do pai, não se aplicava ao homem fascista. Na modelação de seu caráter, a figura materna não foi deslibidinizada e a figura paterna permaneceu dissipada. O ego desse sujeito não se integrou pela experiência do afeto, mas da agressão nas academias militares. O único prazer que esse homem brutalizado nas escolas de cadetes concedia a si mesmo era o da sobrevivência. Suas pulsões sexuais foram subsumidas aos instintos de autopreservação. Porque se tratava, então, de um ego fragilizado e, por conseguinte, extremamente dependente do suporte de estruturas externas, viria a ser contido numa variedade de egos sociais - a nação, a tropa, o Partido e

\footnotetext{
${ }^{73}$ Numa cena intitulada O espião de sua peça teatral Terror e miséria do Terceiro Reich, Bertolt Brecht proveu uma pungente representação da política antifamília do nazismo. Ali se desfiava ao espectador o desalentador retrato de uma família de classe média aterrorizada pela penetração do horror totalitário na sua rotina doméstica. Um casal, em diálogos cifrados, ponderava cada palavra, receoso de que, num deslize de linguagem, deixasse escapara alguma inclinação antifascista diante do filho, um garoto comprometido com a Juventude Hitlerista. Incapazes de decifrar as veladas intenções do menino, o pai e a mãe habitavam um cenário pavoroso. Uma vez que uma alusão inadvertida poderia resultar em denúncia junto a Gestapo, encontravam-se privados da trivial felicidade de uma conversa banal. Não obstante, no nível social propriamente dito, a coesão familiar resistiu ao assalto fascista. Denúncias dentro das famílias tornaram-se casos excepcionais, mais comumente envolvendo depoimentos de esposas da classe operária contra seus maridos, a partir dos quais a Gestapo não conseguia deslindar se a motivação da queixa era de ordem política ou se referia a problemas domésticos do casal. Alhures, a família persistiu como um estável eixo de conexões afetivas e de resistência. Graças à intervenção parental, muitas crianças permaneceram imunes aos argumentos centrais do nazismo. Pais e mães produziram rotas de fuga para subtrair seus filhos do controle governamental. Enviavamnos para atividades nas igrejas ao invés das escolas nazistas, por exemplo. O lar resistiu como um refúgio das pressões externas, uma reserva privada de estabilidade emocional e conforto que se tornou, ao contrário das expectativas do regime, mais e mais desejável aos jovens alemães. BRECHT, Bertolt. Terror e miséria do Terceiro Reich. Tradução: Christine Röhrig, Marcos Renaux, in BRECHT, Bertolt. Teatro completo em 12 volumes, V. São Paulo: Paz e Terra, 1991, 238-50 e VAIZEY, Hester. Op. cit., 2010, 25-7.
} 
as máquinas capazes de engendrar totalidades ${ }^{74}$.

Alçada à linha de frente dos egos totalizantes, a nação era, daí, o cenário de uma grande batalha: a batalha imaginária do fascista contra si mesmo. Ela transcorria em cenários delirantes e avançava até as fronteiras da insanidade porque, ao se referir ao significante "Alemanha" e seus derivados (o exército, a Kultur, o Volk, a raça) o nazista descrevia os processos internos pelos quais seu desejo fora encarcerado numa armadura corporal. Tratava-se de uma luta na qual se transladava, na realidade externa, os processos inconscientes que cada sujeito experimentava em si. Por isso, a nação se oferecia como estrutura de unidade e, assim, opunha-se a tudo que representasse dissolução: a massa, o feminino, o liberalismo, o prazer sensual, a revolução. A única expressão possível de nação era, portanto, um estado masculino governado por soldados. A Gestalt do Volk resultava de uma regeneração pela soma dos exércitos de homens e pela fusão do masculino no masculino para produzir um futuro nomeado “Terceiro Reich", a forma final dos másculos trabalhos bélicos sobre o corpo da Terra, fertilizada pelo sangue das batalhas. A procriação da nação ocorreria apenas entre homens. A constituição egoica do homem fascista, por isso, escapava à linha da genealogia parental: não vinha de um pai e de uma mãe - o soldado nazista era um filho da tropa e irmão dos companheiros de guerra. Constituía-se por meio de uma autofiliação num renascimento a partir da máquina militar. Permanecia, ali, em perpétua atividade. Pois, nessa formação psíquica, o descanso inexistia: não havia possibilidade de relaxamento para um ego sob permanente risco de extinção ${ }^{75}$.

Para esses homens, cujos egos remanesceram alienados das referências parentais e em permanente estado de fusão narcísica numa totalidade simbólica governada pelo horror à dissolução, o fascismo, observou Peter Sloterdijk, produziu um pacto que comungava os soldados caídos em combate com aqueles que lhes sobreviveram. A partir do obsedante tema da vingança aos heróis e aos

${ }^{74}$ THEWELEIT, Klaus. Male Fantasies: Volume 2: Psychoanalyzing the White Terror. Tradução: Stephen Conway, Erica Carter, Chris Turner. Minneapolis: University of Minnesota Press, 2010, 210-22, 223.

75THEWELEIT, Klaus. Op. cit., 82-4, 87-92, 241, 251. 
mártires do movimento, o nazismo criou um ambiente comunal no qual os sobreviventes podiam experimentar socialmente suas doenças mentais privadas. O regime produziu uma neurose nacional cujo sintoma era a comunhão dos vivos com os mortos na guerra relâmpago que, simbolicamente, abria os túmulos para despertar os desaparecidos, ressuscitando-os como tropas de ataque ${ }^{76}$. Daí que a força motriz dessa neurose não fosse homenagear os mortos, mas transcender a morte. Pois sobreviver, ressaltou Elias Canetti, significava atestar a própria invulnerabilidade e, assim, experimentar uma ilusão de superioridade em relação aos que tombaram. Para o sobrevivente num campo de batalha todos os mortos lhe pertencem. Seu triunfo é mais explícito pelo contraste com o número de homens que caíram em seu lugar77.

Pois então o que era Münchhausen senão uma extensa apologia à sobrevivência a qualquer custo? Quem foi o Barão afora o filho sem pai nem mãe, narcisicamente fixado na juventude e que levou o seu desejo de superar a morte ao extremo? Não era esse personagem aquele que deixava um inconsequente rastro de destruição por onde passava para atestar sua indestrutível vitalidade? Münchhausen, o errante ungido pela eternidade e galvanizado por uma constante disposição em superar as adversidades, produzia uma imagem radicalmente idealista do homem alemão. Mas ao mesmo tempo em que incidia na idealização, provia um retrato que desvelava a verdade de seus múltiplos desejos: desejo de evasão, de ultrapassar fronteiras, de gozar todas as situações, de saciar todos os apetites numa pletora de possibilidades, de jamais perecer, de persistir numa infância sem fim, de nunca submergir no ciclo do devir para remanescer em perpétuo estado de encantamento juvenil e de fusão no mundo maravilhoso da filiarquia.

Münchhausen, afirmou Linda Schulte-Sasse, acomodava uma variedade de aspectos - a autorreflexão das formas codificadas pelo cinema alemão, a

\footnotetext{
76 SLOTERDIJK, Peter. Crítica à razão cínica. Tradução: Marco Casanova, Paulo Soethe, Pedro Costa Rego, Maurício Mendonça Cardozo, Ricardo Hiendlmayer. São Paulo: Estação Liberdade, 2012, 560-1.

77 CANETTI, Elias. Crowds and Power. Tradução: Carol Stewart. Nova York: Farrar, Straus and Giroux, 1984, 229.
} 
sobreposição da libertina moralidade aristocrática do século XVIII contra a norma burguês-fascista do século XX, o movimento narrativo de uma trajetória circular fragmentada, descontínua e costurada aos solavancos - para euforicamente celebrar uma única coisa: a alegria de viver. De modo algum esse Barão aventureiro se envergonhava de existir em estado de permanente adolescência e de se evadir de qualquer compromisso. Habitava, como Peter Pan, um mundo infantilizado, pré-edípico, esterilizado pela onipotência narcísica, dominado pela libido polimórfica para a qual as relações parentais não tinham importância alguma ${ }^{78}$. Portanto, não era o filme uma fantasia que escalonava o desejo, mas o desejo descrito ipsis litteris numa forma fantasmática.

Para formular o desejo como tal, Münchhausen assumia, então, a única modalidade de representação possível pela qual a fantasia não o ocultaria em formas secundárias, mas o desvelaria sem mediações: a expressão onírica, na qual a psicanálise fixou o território próprio do desejo ${ }^{79}$. E, para ajustar essa representação num sistema estético codificado junto ao público, o filme construía seus múltiplos enredos a partir do gênero em que melhor se assentam os estados de narcisismo primário, de delírio lisérgico e de sensualidade desviante: a forma fantástica na sua vertente do maravilhoso.

A narrativa fundamental da história fantástica impõe a existência de um universo com suas próprias regras sobre o qual se introduziu um desequilíbrio quando a trama se encerra, porém, o equilíbrio originário não se restabelece. Houve a passagem de um estado a outro, uma maturação do personagem, um abandono da perspectiva infantil para a percepção adulta. $\mathrm{O}$ desfecho da obra fantástica impõe uma ordem estática onde tudo antes era dinamismo. A estabilidade ocupa a cena e interrompe as modificações. Pelo que o sobrenatural serve como um meio de conjurar a mutação, de romper o equilíbrio, de desafiar a realidade - ou, mais precisamente, de desestabilizar os modos convencionais

\footnotetext{
78 SCHULTE-SASSE, Linda. Op. cit., 306, 316.

${ }^{79}$ FREUD, Sigmund. A interpretação dos sonhos in FREUD, Sigmund. Obras psicológicas completas de Sigmund Freud: Volume IV. Tradução: José Octávio de Aguiar Abreu, Christiano Monteiro Oiticica. Rio de Janeiro: Imago, 1996, 158, 166-7. ROUDINESCO, Elisabeth: PLON, Michel. Dicionário de psicanálise. Tradução: Vera Ribeiro, Lucy Guimarães. Rio de Janeiro: Zahar, 1998, 147.
} 
de decodificação da realidade ${ }^{80}$.

Os gêneros derivados do fantástico, por conseguinte, assemelham-se preliminarmente à descrição dos quadros psicopáticos da mente humana ou da percepção alterada por narcóticos. Nesse estado, o personagem se tornou incapaz de discernir os fenômenos da realidade de suas elucubrações imaginárias. Desceu a uma experiência de fusão do sujeito ao meio, de suspensão do tempo e de imersão num presente absoluto. E, porque entre a matéria e a ideia não há mais cisão, as leis da natureza também não funcionam de modo ordinário. $\mathrm{O}$ tempo e o espaço não reverberam suas qualidades físicas tal qual no mundo natural, nem podem ser medidos por escalas convencionais ${ }^{81}$.

Por extensão, considerou Tzvetan Todorov, o gênero incide nos modos cognitivos da infância, em seu estágio pré-verbal. Da mesma maneira que os personagens de uma narrativa fantástica, nessa etapa a criança viveu um tempo elástico e um presente contínuo. Num e noutro caso, o mundo físico se confunde com as percepções psíquicas. O infante desconhece as convenções que, pelo intermédio das palavras, fixam sentidos estanques aos objetos. Como na psique da criança, a história fantástica também não distingue o eu do mundo exterior, mas os integra numa mesma ação pelo que não se estabelece a diferença entre sujeito e objeto. Daí, os objetos se comportam de modo atípico, por vezes bizarro. Suas formas e cores rejeitam as convenções, seus contornos parecem imprecisos. Objetos, nesse universo, agem. Conduzem-se, portanto, como sujeitos e, assim, realizam, dentro de suas inauditas capacidades, aquilo que os personagens desejam ou temem. Do que Todorov concluiu que a peculiaridade desse gênero é o gradual apagamento do limite entre sujeito e objetos ${ }^{82}$.

O universo descrito pela narrativa fantástica se organiza por relações próprias de causa e efeito, muitas vezes governadas por coincidências excepcionais porque jamais resultam de algum acaso (como norma do gênero,

\footnotetext{
80 TODOROV, Tzvetan. As estruturas narrativas. Tradução: Ligia Perrone-Moisés. São Paulo: Perspectiva, 2013, 162-4.

81 TODOROV, Tzvetan. Introdução à literatura fantástica. Tradução: Maria Clara Correa Castello. São Paulo: Perspectiva, 2014, 46.

82 TODOROV, Tzvetan. Op. cit., 123-7.
} 
não existem acasos). Uma vez que todos os acontecimentos são potencialmente determinantes, tudo então se apresenta sobrecarregado de sentido. Nesse pandeterminismo, Todorov reconheceu também uma panssignificação a partir do que, em todos os objetos, subjaz a possibilidade de uma sobreinterpretação. A relação entre as coisas e as palavras sofre um abalo - há uma submersão da ideia com a matéria com a qual o sentido metafórico dos símbolos e imagens se desvanece. As ideias, então, tornam-se sensíveis ${ }^{83}$.

Nesse momento, a narrativa oferece um vislumbre do real - a imagem cessa de conotar para se tornar denotação. De maneira que, na corte de Catarina, o Barão deixou de experimentar iguarias preciosas como esmeraldas e rubis. Do mesmo modo, chegava à Turquia tão velozmente quanto um disparo de canhão. Nessas circunstâncias, a representação não provia um comentário imaginário,
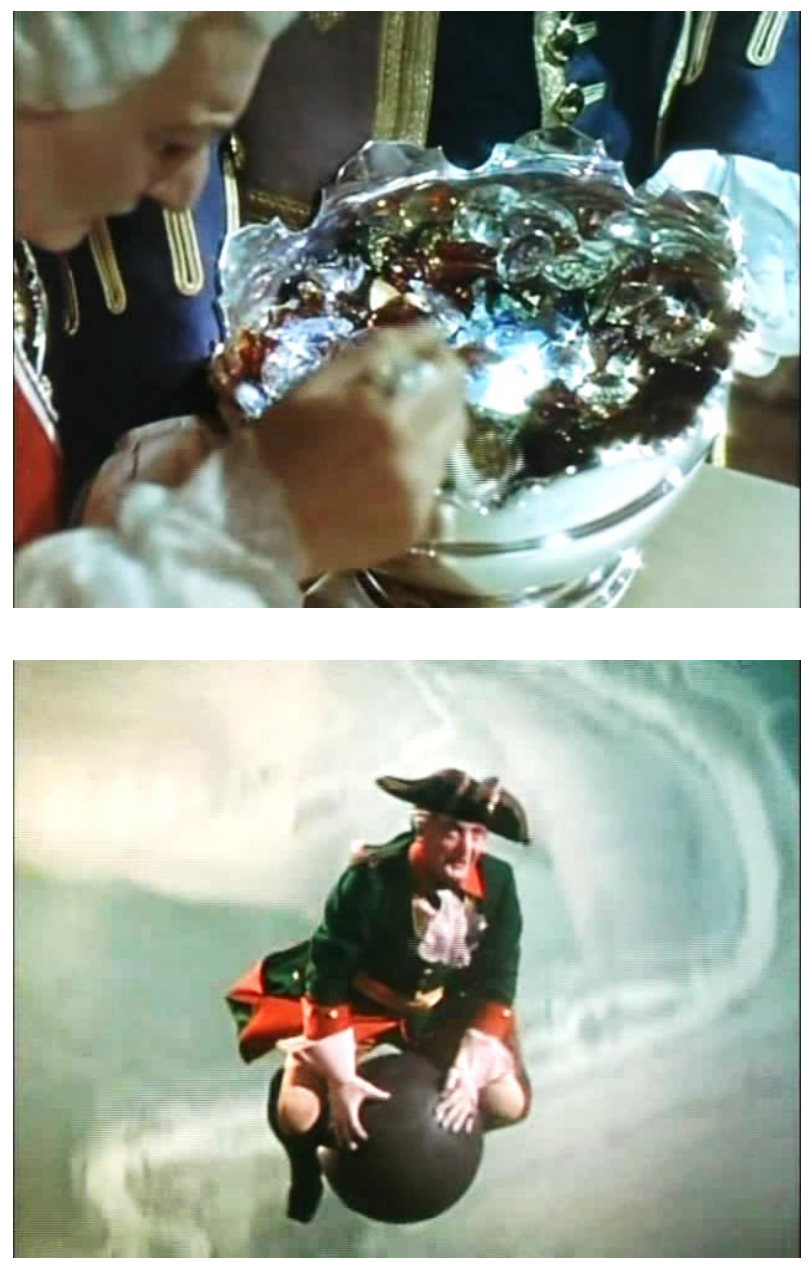

Figs. 3.2 e 3.3: Michael Bohnen e Hans Albers. mas realizava na imagem a própria situação descrita. Fundindo o sujeito ao objeto para descredenciar o valor conotado, Münchhausen, então, se apropriava de um dos marcadores do maravilhoso, a velocidade, para fazer dela o traço explícito da hipérbole. Era a estética do exagero, então, que desfazia o laço entre o simbólico e o real, transformando o imaginário em sentido denotado. O mensageiro de Münchhausen atravessava continentes num estalar de dedos. Um tiro com a espingarda de Christian cobria centenas de quilômetros em

83 TODOROV, Tzvetan. Op. cit., 118, 120-2 e TODOROV, Tzvetan. As estruturas narrativas. Tradução: Ligia Perrone-Moisés. São Paulo: Perspectiva, 2013, 157. 
segundos. E, na Lua, um dia selenita se igualava a um ano terrestre. “O tempo está quebrado", lamentava Christian antes de se esvanecer em fumaça sob efeito dessa temporalidade mortal.

Confundindo o sujeito e o objeto, destituindo o valor metafórico das representações e desconstruindo as conexões lógicas de tempo e espaço, Münchhausen produzia, pela marcação do fantástico, uma forma explícita do narcisismo primário, comum à criança e ao paranoico. Descrevia a situação mental pela qual o infante e o demente realizam sua existência tomando a si mesmos como medida de todas as coisas. O filme efetuava esse imaginário narcísico encarnando-o na imagem do homem em permanente estado de ubiquidade, de onipotência e de libertação física, submergindo-o em territórios e subjetividades alteritárias, satisfazendo incessantemente o desejo de fusão. Münchhausen descarregava sua energia no gozo da violência desenfreada que emulava o sadismo do narcisismo primário. Essa agressividade, a codificação do fantástico comutava em humor. O filme, então, permitia o extravasamento da violência retida provendo-lhe o destino do riso e da destruição. Do que Eric Rentschler vislumbrou em Münchhausen a fantasia da apoteose de um herói viril e vital em completo, ainda que ilusório controle de seu destino. Reconheceu no filme um perfeito exemplo daquela instância que Peter Sloterdijk qualificou como razão cínica: a adesão a uma justificativa lógica que abandonou as pretensões idealísticas para sustentar os atos não mais num esteio ético, mas, ao contrário, aderindo-os à pura realidade da ação, oferecendo toda brutalidade de um gesto como afirmação da sua verdadeira moralidade ${ }^{84}$. Daí, ao seu ver, Münchhausem era o personagem que deixava de fingir ser um ariano virtuoso para se comportar como um verdadeiro ariano. Realizava aquilo que o nazista desejava, deixando o traço da destruição após si como uma assinatura de sua passagem sem mais se preocupar com a responsabilidade das catástrofes em seu entorno. Comportando-se como um judeu sem pátria e sem rumo, revelava-se o ariano para além das idealizações ${ }^{85}$.

\footnotetext{
84 SLOTERDIJK, Peter. Op. cit., 31-6.

85 RENTSCHLER, Eric. Op. cit., 207, 211.
} 
Essa regressão narcísica, matizada pela violência, não obstante, tanto se referia ao desejo descarnado de desnudar a própria essência, quanto também incidia numa fantasia diversa, de rejeição à realidade totalitária. Por esse viés, o Barão, com sua alegria por simplesmente existir e em simbiose com os objetos produzidos pelo maravilhoso, colocava-se no lugar da denegação, da obstinada recusa em reconhecer os medonhos prodígios que o nazismo de fato produzia. Sua imagem funcionava, então, como um sistema defensivo, isolando seu espectador da realidade do extermínio judaico e da carnificina nos campos de batalha. E essa fuga da realidade, como esclareceu perfeitamente Hannah Arendt, naturalmente, também era uma fuga da responsabilidade ${ }^{86}$.

Nos exageros hiperbólicos que rejeitavam o princípio da realidade, havia no filme uma interpelação direta ao desejo numa profusa gama de variedades que coincidiam no denominador do impossível. Da evasão ao gozo absoluto, da regressão pré-edípica à transcendência da vida eterna, nenhum desejo formalizado no filme poderia encontrar meios de fruição mais satisfatórios além da destruição ou da fabulação. Porque somente prestava contas ao princípio do prazer, o filme cartografava, desse modo, um território miraculoso onde todo desejo coexistia com seu objeto, exceto um: o objeto de satisfação erótica. Esse somente subsistia como possibilidade narrativa.

O fantástico, per se, franqueia uma conturbada aproximação dos personagens com seu desejo, sobretudo seu desejo sensual. O gênero, notificou Todorov, permite a formulação de tabus sexuais - incesto, homossexualidade, necrofilia - constituindo, assim, um sistema narrativo propício para desacorrentar o desejo da censura. A satisfação sexual, que encontra um obstáculo à sua realização natural pela manifestação do sobrenatural, procura meios de deflexão, evadindo-se em formas pervertidas, sobretudo de ordem

\footnotetext{
86 ARENDT, Hannah. Após o domínio nazista: notícias da Alemanha in ARENDT, Hannah. Compreender: formação, exílio e totalitarismo (ensaios) 1930-54. Tradução: Denise Bottman. São Paulo: Companhia das Letras. Belo Horizonte: Editora UFMG, 2008, 273.
} 
sádica $^{87}$.

Em sintonia com esses marcadores, na figura do Barão, o cinema da época fascista produziu uma vibrante imagem do desejo sensual masculino, o qual se desviava do objeto e da realização no plano do ato para encontrar a descarga no volteio verbal. Sua trajetória erótica progredia de elaborações extremamente sensuais - os romances plenos de carnalidade com Louise La Tour e Catarina da Rússia e a aventura com a infeliz Isabella - à paz do santuário doméstico ao lado de uma gentil e maternal baronesa. Na formalização dessas peripécias eróticas, Eric Rentschler reconheceu a expressão da fantasia fascista de exorcismo dos poderes do feminino pela sua objetificação como meio de gratificação ${ }^{88}$.

O donjuanismo, contudo, não opera no sentido de destituição do feminino, mas pelo investimento do desejo num objeto peculiar, a mulher impossível. O verdadeiro Don Juan salta de uma mulher a outra numa infatigável procura, em busca de algo que a experiência real do feminino não lhe provê jamais. Vive uma situação sem saída porque a realidade não produziu esse mais-além da mulher. O donjuanismo, considerou Lacan, deixa entrever um meio

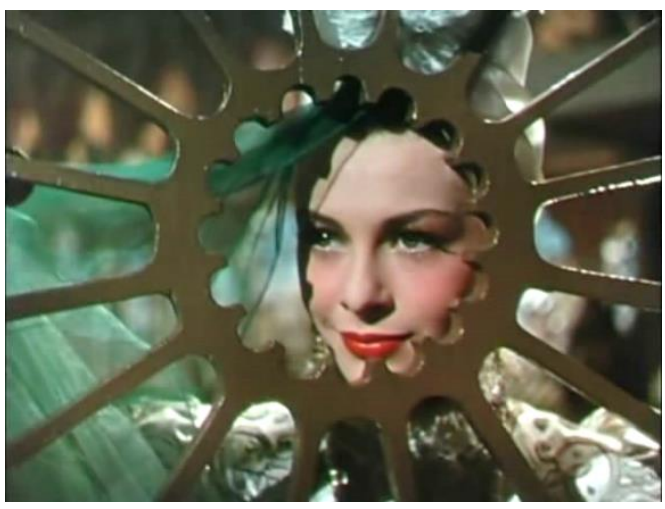
fundamentalmente bissexual de fixação do objeto de desejo. Ele almejava por uma mulher, por assim dizer, fálica ${ }^{89}$.

Porque o falo constitui o significante mestre, a mulher fálica, cujo protótipo é a mãe, provê o chão inicial da subjetivação. Ela simboliza o local fundamental em que o complexo de Édipo comuta a Coisa na Lei

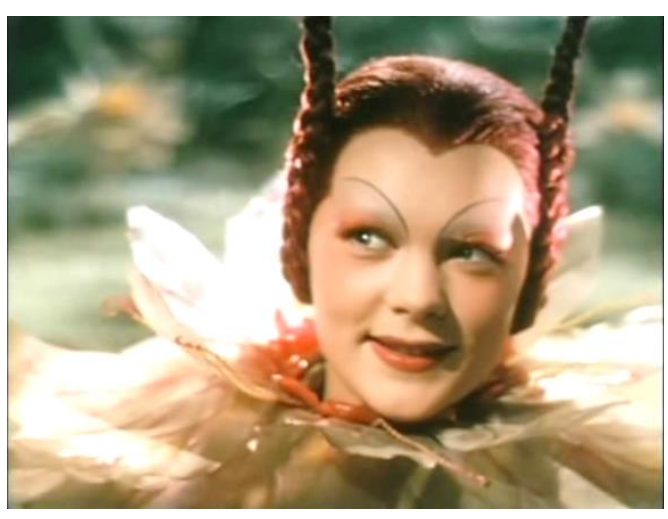

Figs. 3.4 e 3.5: Ilse Werner e Marianne Simson.

87 TODOROV, Tzvetan. As estruturas narrativas. Tradução: Ligia Perrone-Moisés. São Paulo: Perspectiva, 2013, 161 e TODOROV, Tzvetan. Introdução à literatura fantástica. Tradução: Maria Clara Correa Castello. São Paulo: Perspectiva, 2014, 140.

88 RENTSCHLER, Eric. Op. cit., 207-8.

89 LACAN, Jacques. O seminário Livro 4: a relação de objeto. Tradução: Dulce Duque Estrada. Rio de Janeiro: Zahar, 1995, 433. 
moral pela instauração simbólica do falo no lugar da autoridade. De modo que o donjuanismo nem se realiza fisicamente numa mulher, nem tende à atração homoerótica, mas fixa o gozo na dimensão do símbolo. Daí que Münchhausen não comportasse indícios ou traços homoeróticos alhures descritos em algumas variedades da personalidade dita fascista. Sua orientação sexual se voltava integralmente às mulheres, às quais ele colecionava como mementos de prazeres transitórios - tinha, para isso, uma parede de seu castelo em Bodenweder decorada com retratos das damas que cederam aos seus galanteios. Do que sua sexualidade, por esse meio, transitava entre a imagem e o símbolo. $\mathrm{O}$ interesse erótico do Barão, observou Linda Schulte-Sasse, não se fixava nas mulheres, mas na possibilidade de tecer e ornamentar tramas em torno delas. O erotismo encenado no filme desterrava reiteradamente as mulheres da paisagem do desejo para as encarnar como narrativas. A jovem Louise La Tour, uma vez desfrutada, não inspirava mais nenhum sentimento libidinal. Sempre disponível, tornava-se um objeto de zombaria, surgindo mais velha e mais ridícula a cada cena. As mulheres inacessíveis, ao contrário, permaneciam desejáveis porque, em torno delas, grandes histórias podiam prosperar. Isabella D'Estre, aprisionada num convento e a decapitada mulher da Lua pareciam muito mais excitantes ao Barão porque suas belas figuras se ofereciam incompletas. Uma intricada ambientação obstruía o acesso visual a elas, recortando-lhes a imagem atrás de ornamentos, grades e pétalas de flores. A mulher não acessível era mais desejada, de modo que o Barão evitava interagir com a nudez feminina: cobria com um lenço uma estátua despida e confidenciava a Cagliostro que apreciava mais a imagem de uma dama pintada num quadro quando vista de $\operatorname{costas}^{90}$.

Esse recato quase puritano do Barão, pelo que a sensualidade feminina somente era erótica enquanto ideia, tornou-se um elemento vagamente perceptível no filme porque o personagem vinha às telas na figura do mais impudico dos atores alemães, Hans Albers.

Um notório dissidente que rejeitava qualquer vínculo social com os dignitários do Partido, Albers despontou tardiamente ao cinema weimariano

\footnotetext{
${ }^{90}$ SCHULTE-SASSE, Linda. Op. cit., 315.
} 
onde se elevou como um dos últimos grandes galãs do período. Seu renome, contra a vontade de Goebbels, prosperou na Alemanha nazista ${ }^{91}$. Pertencia àquela geração que incluía grandes personalidades da indústria cultural como Heinz Rühmann e Heinrich George, os quais atravessaram o regime liberal para o domínio autoritário, pelo que informavam a continuidade da Kultur e da nação a despeito do derretimento do Estado. Eram figuras familiares, símbolos da germanidade indexados positivamente à cultura de massa, genuínos porta-vozes de seu tempo cujas imagens revividas no apogeu do Reich conciliavam a virulência do regime fascista com o mal recalcado passado liberal ${ }^{92}$.

Ao lado de astros como Willi Fritsch, Lilian Harvey e Zarah Leander, Albers compunha um grupo de performers resilientes à fixação das idealizações de gênero e raça recomendadas pelo regime, o que reforçou a sugestão de que constituía uma figura transgressiva dentro da nova ordem ${ }^{93}$. Como muitas celebridades cujo status de ícone alcançara dimensões mitológicas, passou a representar uma presença metafórica de negação do nazismo ${ }^{94}$. O que resultou em leituras contraditórias pelo que seu apelo viril transitava numa fronteira mal definida entre a sensualidade liberal e a violência fascista.

Albers tornou-se um dos atores mais populares da Alemanha porque, na opinião de Klaus Kreimeier, sua personalidade nos filmes apunha um continentalismo kitsch sobre papeis contemporâneos. Seus personagens produziam assim um misto de espírito aventureiro e otimismo inquebrantável numa mise en scène plena em energia. Essa explosiva combinação preservara-o como um dos poucos ícones cinematográficos autênticos do período nazista e

\footnotetext{
${ }^{91} \mathrm{O}$ Ministro aparentemente tomou como um insulto o fato de que Albers, a perfeita imagem do novo homem alemão, tivesse rejeitado abandonar sua amante, a atriz judia Hansi Burg. Durante o endurecimento das políticas antissemitas, o astro transladou sua companheira para Londres onde ela permaneceu até o final da guerra, após o que o casal voltaria a viver junto. O contrato que o vinculou à UFA em 1935, ademais, garantia-lhe o direito de recusar assuntos, diretores e roteiros, uma exigência do ator que rejeitava emprestar sua imagem para qualquer tipo de propaganda fascista, à qual Goebbels concedeu porque Albers era um dos poucos astros alemães de renome internacional. KREIMEIER, Klaus. The Ufa Story: a History of Germany Greatest Film Corporation, 1918-1945. Tradução: Robert Kimbler, Rita Kimbler. Berkeley, Los Angeles: University of California Press, 1999, 290, 292 e RENTSCHLER, Eric. Op. cit., 197-8.

${ }^{92}$ HAKE, Sabine. Popular Cinema of the Third Reich. Austin: University of Texas Press, 2001, 90.

${ }^{93}$ CARTER, Erica. Op. cit., 59, 61.

${ }^{94}$ HAKE, Sabine. Op. cit., 228.
} 
mais uma daquelas figuras a qual o regime não logrou reduzir aos denominadores da sua doutrina ${ }^{95}$.

Rentschler, ao contrário, divisou na persona de Albers, com seus cabelos louros e seus olhos azuis, o ambivalente protótipo do herói mítico alemão. Pois diferentemente dos empedernidos galãs do Terceiro Reich, ele parecia não padecer de nenhuma inibição. Projetava confiança, disposição e bom humor. Foi talvez o único ator de sua geração apto a expressar o desejo erótico sem conjurar implicações mórbidas ou destrutivas ${ }^{96}$. Um ponto de vista radicalmente contestado por Sabine Hake que descreveu sua personalidade cinematográfica como a figura do macho teutônico endurecido por uma hipermasculinidade, a qual, de tão excessiva, beirava à histeria. As caracterizações de Albers, desse ponto de vista, eram assertivas, mas com uma disposição à rudeza e à crueldade, confiantes num nível quase patológico, autossuficientes, porém com uma forte inclinação para a misantropia. Graças à sua presença marcante, seus filmes exploravam enredos de selvageria que libertavam energias subterrâneas para produzirem grandes espetáculos de destruição. Sua virilidade, desse modo, raramente envolvia o apelo romântico, mas sim, a urgência e a fugacidade do sexo, destituindo-o de qualquer outro valor que não fosse a consumação do desejo. Com seu olhar azul metálico, tornou-se o último macho do cinema alemão, aquele que mais chegou perto da forma do super-homem ariano sem pactuar com o ideal racializado da doutrina. Pois, deduziu Hake, Albers explicitava abertamente suas imperfeições. Tornou-se uma figura ideal encarnada numa pessoa real e em personagens plausíveis, o que desatrelava sua personalidade pública ariana da problemática ratio do discurso racial nazista ${ }^{97}$.

Hans Albers, fosse qual fosse o ponto de vista, assemelhava-se tão perfeitamente ao novo homem alemão por trafegar nas zonas limítrofes da representação onde beirava à antítese do sujeito totalizado. Na sua imagem, assentava-se a forma da criatura ariana, mas não seu pleno conteúdo. Essa qualidade tornava-o apto para representar a razão cínica do homem que se

\footnotetext{
${ }^{95}$ KREIMEIER, Klaus. Op. cit., 292.

${ }^{96}$ RENTSCHLER, Eric. Op. cit., 200.

${ }^{97}$ HAKE, Sabine. Op. cit., 227.
} 
conduzia nas formas do fascismo, prosperando sob sua égide, sem fazer disso um problema de consciência. Mas servia, igualmente, para afirmar os sistemas de denegação que apartavam o ato da reflexão. De modo que, como muitas pessoas que apreciavam suas caracterizações na Alemanha nazista, seus personagens admitiam se parecer com o sujeito idealizado pela doutrina sem com isso incorrer no assentimento aos seus conteúdos. Sua presença à frente de um filme, então, indicava a face externa da acomodação: era mesmo a pura exterioridade do sujeito que, enquanto resistia, ao mesmo tempo aquiescia, dando de ombros aos desastres produzidos pelo fascismo porque não se sentia nem remotamente responsável por eles. Essa qualidade ambivalente encontrou sua perfeita realização nas inconsequências do Barão em Münchhausen, mas também podia ser entrevista na sua caracterização subsequente do melancólico marinheiro de Große Freiheit Nr. 7 (“Grande Liberdade, Nr. 7”, Helmut Käutner, $1944)^{98}$.

Seu personagem em Münchhausen produzia uma síntese final de imagens significativamente acumuladas numa variedade caracterizações que o precederam nos anos 1940. Reunia as múltiplas qualidades do barão sensual, galhofeiro e ousado que encarnou em Trenck, der Pandur ("Trenck, o Pandur", Herbert Selpin, 1940), do milionário que abandonava uma existência de privilégio em busca do prazer de viver em Ein Mann auf Abwegen (“Um homem em desatino", Herbert Selpin, 1940) e do violento aventureiro em Carl Peters (Herbert Selpin, 1941). O elemento que Münchhausen adicionava a todas essas representações era o humor. Albers participara de filmes nos mais variados gêneros. Porém, mesmo nas produções voltadas ao cômico como Bomben auf Monte Carlo (Loucuras de Monte Carlo, Hanns Schwarz, 1931) ou Der Mann, der Sherlock Holmes war (Sherlock Holmes, Karl Hartl, 1937), o elemento viril de sua persona tendia a prevalecer (em ambos os filmes, Heinz Rühmann assumia o

\footnotetext{
98 Nos seus últimos filmes durante o Terceiro Reich, Albers adicionaria um tom de melancolia e masoquismo aos seus personagens, considerou Sabine Hake, ainda que jamais fosse destituído de uma aura de autoridade agressiva. Essa evolveu para a autoparódia nos anos de desnazificação quando sua presença filme servia como figura de revide nos processos de negociação com o passado nazista e o ator se viu consignado a repetir seus grandes papeis de Münchhausen e Große Freiheit Nr. 7. HAKE, Sabine. Op. cit. , 224, 228.
} 
encargo de sustentar o riso).

Münchhausen marcaria, portanto, um ponto atípico de sua carreira. Do início ao fim da história, o ator se deixava levar por um inédito estado de graça. Produzia momentos de franco riso, sobretudo nas muitas falas carregadas de duplos sentidos. "Você é o mesmo Münchhausen que a Duquesa de Choiseul inadvertidamente escondeu num armário em que eu já tinha sido depositado?", perguntava-lhe Giacomo Casanova, ao que o Barão respondia sem pestanejar natürlich pelo que o substantivo Shrank ("armário"), os verbos verstecken (esconder) e deponieren (depositar) e o advérbio "naturalmente" sugeriam algo entre um duplo coito ou um ménage à trois. Em outros momentos, o humor negro beirava o puro nonsense. "Quem pode decidir o que é melhor se dificilmente alguém sabe o que é bom?", retorquia o Barão quando, indagado sobre sua fé e sua pátria, todas as opções pareciam igualmente desagradáveis.

\section{$\underline{\text { Humor }}$}

Courtade e Cadars foram os primeiros críticos a apropriadamente reconhecerem que as tiradas satíricas e as gags humorísticas adicionavam uma tonalidade picante às aventuras de Münchhausen ${ }^{99}$. Esse tipo de humor remanesceu como um dos elementos mais duradouros e apreciados no filme, mas pouco cotejado nas análises. Uma obra que tocava em elementos cômicos sem nunca incidir no gênero da comédia, Münchhausen era atravessado por anedotas e troças que asseguravam uma sustentada atmosfera de vivacidade e graça. As tiradas satíricas, no filme, adotavam formas sui generis: aforismos, aporias, galanteios. E também eram expressas visualmente, quando a imagem servia ao propósito de conotar um conteúdo. O humor, assim, traficava temas e ideias contraditórias para dentro da ação.

Uma tirada satírica, observou Freud, funciona como um instrumento que mascara conteúdos recalcados numa fachada cômica, permitindo, por esse meio, sua irrupção no consciente. Ela faz uso do cômico e do humor justamente para

\footnotetext{
${ }^{99}$ COURTADE, Francis; CADAR, Pierre. Op. cit., 297.
} 
subornar o ouvinte, neutralizando sua atenção e, assim, alcançar elementos subjacentes e inibidos pela resistência psíquica, sem o que não produziria a descarga do riso, mas, ao contrário, repulsa e desprezo ${ }^{100}$. Pelo que Freud reconheceu nela uma relação de trânsito de energia psíquica similar ao dos sonhos. Tanto os sonhos quanto os chistes promovem um relaxamento da intenção intelectual, permitindo uma condensação que sumariza conteúdos complexos em poucos elementos. Estabelecem, ademais, jogos de conteúdos que trabalham pela suspensão da crítica racional, submergindo o pensamento no inconsciente em modos similares aos da elaboração psíquica infantil. O prazer proporcionado pelo chiste remonta aos primórdios da atividade simbólica. Ele carrega consigo uma rememoração do período lúdico da infância no momento de aquisição da linguagem, quando criar palavras significava mediar a realidade pelo recurso de uma poderosa ferramenta, o significante. Seus processos favorecem, então, a regressão da mente a um estado embrionário, onde as forças inibitórias perdem sua potência, permitindo o afloramento de ideias

\footnotetext{
100 Chistes ou tiradas satíricas abreviam uma expressão, oferecendo à atenção os mínimos elementos necessários à significação. Sua brevidade sinaliza que se formou neles um conteúdo substituto pelo que se pode localizar os vestígios dos conteúdos aludidos. Consistem num meio único de expressão porque promovem um desvio em relação ao pensamento ordinário. Operam um descolamento de ênfase que desloca a orientação do sentido previsto no início de seu enunciado. Não sendo abertamente declarado, esse sentido subjaz como algo implícito, ora condensando elementos, ora comutando-os em duplos sentidos. O efeito imediato desse procedimento é, então, uma alternância entre o desconcerto e o esclarecimento. Nos chistes subjaz, portanto, um cálculo pelo qual o conteúdo desfigurado na expressão reaparece na revisão inconsciente do ouvinte, restabelecendo ali sua forma e sentido. O efeito do chiste, então, consiste na modulação da elisão. Funcionam do mesmo modo que o lapso, mediando um duplo acontecimento. Um conteúdo é recalcado no circuito da mensagem e do código. Em seguida, outro conteúdo é impresso em seu lugar no nível do discurso. Como observou Jacques AlainMiller, as tiradas satíricas estabelecem uma infração premeditada do código fundamental da linguagem pela imposição de um nonsense que chacoalha a significação. Desafiam, assim, a estabilidade do Outro. Porque fazem vacilar a ordem linguística, detêm um poder subversivo: impõem no discurso uma zona de indeterminação a partir da qual figuram um novo saber que desestabiliza as relações ordinárias do significado com o significante. Mais propriamente, acentuam o efeito de deslizamento, as permutações e os jogos cognitivos pelas quais o significante engendra novos significados. ALAIN-MILLER, Jacques. Percurso de Lacan: uma introdução. Tradução: Ari Roitman. Rio de Janeiro: Zahar, 1997, 28-319, FREUD, Sigmund. Os chistes e sua relação com o inconsciente in FREUD, Sigmund. Obras psicológicas completas de Sigmund Freud Volume VIII. Tradução: Margarida Salomão. Rio de Janeiro: Imago, 1996, 58-9, 64-6, 152-3, 191 e LACAN, Jacques. O seminário, livro 5: as formações do inconsciente. Tradução: Vera Ribeiro. Rio de Janeiro, Zahar, 1999, 28, 46, 52 e LACAN, Jacques. O seminário, livro 16: de um Outro ao outro. Tradução: Vera Ribeiro. Rio de Janeiro: Zahar, 2008, 63, 88-9.
} 
represadas ${ }^{101}$.

A reversão aos determinantes da ideação infantil parecia a Freud essenciais para sustentar a produção do cômico. Essa conexão entre o cômico e a infância sugeria um caso peculiar de regressão pelo que tudo o que é passível de se desvelar na comédia, abriu caminho à consciência mediante o recuo à etapa infantil. Do que Freud assinalou no cômico não uma recordação do prazer, mas a rememoração distanciada do desamparo da criança diante do mundo. O cômico torna risível situações embaraçosas que guardavam semelhança com a inépcia das crianças em coordenar seus movimentos, em exagerar fantasiosamente as coisas pela sua falta dos sensos de proporção e de quantidade e em suas mascaradas, pelas quais se esforçavam em imitar os adultos. O que alinha o chiste, o cômico e o humor ao universo pueril são, pois, os afetos dolorosos da fase infantil dos quais, mais tarde, o adulto zomba. $\mathrm{O}$ humor, assim, obstrui a empatia e a compaixão, constituindo uma das mais eficientes modalidades de resistência defensiva contra o afloramento do desprazer implícito nas memórias da infância. Permite a libertação de emoções aflitivas de modo que um conteúdo penoso pode ser suspendido e a energia psíquica economizada na sua contenção reflui na descarga pelo riso. De tal modo que, enquanto o chiste economiza as inibições, o humor economiza os sentimentos ${ }^{102}$.

O humor provê um lenitivo a um ego afligido por alguma angústia. Tornao refratário aos traumas do mundo externo, transformando os fatores de sofrimento em oportunidades de prazer. Consiste num processo de rebeldia que afirma o poder do ego e a primazia do prazer contra a violência das circunstâncias reais. Pois, pelo humor o sujeito se recusa a sofrer. Ao fazer graça, ele se coloca acima de uma situação adversa. Investe a si da superioridade do verdadeiro adulto que dá de ombros aos perigos do mundo como se esses fossem tolices de crianças ${ }^{103}$.

Em Münchhausen, o intercâmbio entre o chiste e o humor, com todas as suas

\footnotetext{
101 FREUD, Sigmund. Op. cit., 166-7, 169, 197 e LACAN, Jacques. O seminário, livro 5: as formações do inconsciente. Tradução: Vera Ribeiro. Rio de Janeiro, Zahar, 1999, 28, 52.

102 FREUD, Sigmund. Op. cit., 219-20, 222-3, 227.

103 FREUD, Sigmund. Op. cit., 170-1.
} 
implicações psicoemocionais, intermediava, no nível dos diálogos, os elementos regressivos que, no nível formal, coincidiam com a filiação ao gênero fantástico. Disso se presume no filme uma variedade de elementos voltados a construir um universo defensivo, pautado na imaginação infantil, encenado num mundo povoado por caricaturas de figuras autoritárias, sempre passíveis de serem degradas pela imitação ou pelo desmascaramento. Tudo na obra parecia suscitado por uma relação entre o pequeno e o grande, sendo esse invariavelmente rebaixado às dimensões daquele. Porque estabelecia uma atmosfera que impunha a censura ao princípio da realidade e mediava a fala pela tirada satírica, Münchhausen comutava o horror em humor - esse servia como barreira àquele. Do que resultava que o riso se produzia a partir de situações pavorosas. E essas, de sua parte, assumiam uma tonalidade erótica na qual o conteúdo violento se confundia com a saciedade do desejo.

Linda Schulte-Sasse frisou que, no mundo tresloucado por onde o Barão errava, o orgânico se confundia com o inorgânico, a cultura com a natureza e os homens com as coisas. O corpo humano era ali tratado como objeto num processo de dessubjetivação cuja principal figuração consistia num tema recorrente: as cabeças cortadas. A metáfora principiava como uma transação erótica, quando o Barão convidava a Czarina a "perderem a cabeça" em prazeres sensuais. Paulatinamente, o chiste evolvia em ameaça concreta. Na corte do Sultão Adbul Hamid, a cabeça do Barão pendeu em arriscadas barganhas. Mais tarde, Münchhausen viria a se lembrar do reino de terror da Revolução Francesa, quando as cabeças eram arrancadas dos corpos em nome da razão. Linda Schulte-Sasse concluiu que o filme tematizava a realidade de um corpo social que perdera sua cabeça e, daí, passou a ser governado por poderes masculinos e irracionais: o Sultão, o Doge e a Czarina (que, no filme, era descrita por um cortesão como "Catarina, o Grande"). O tema
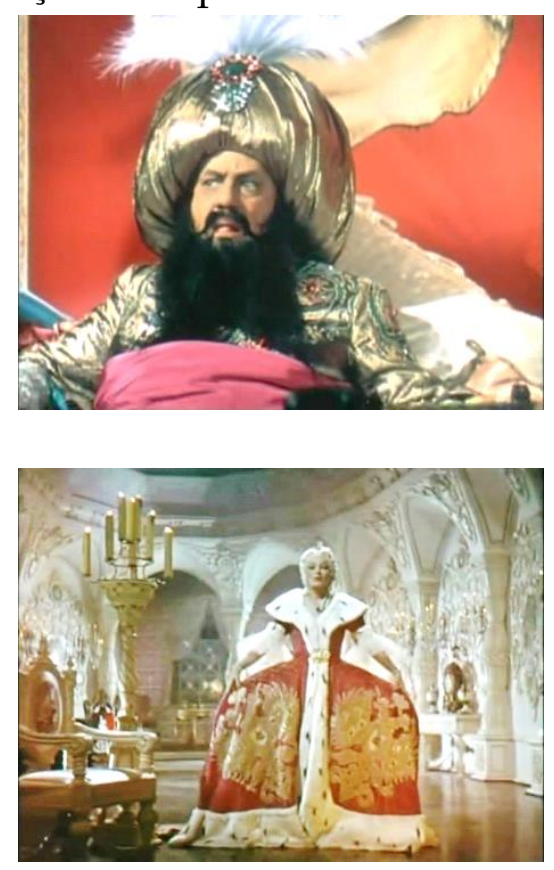

Figs. 3.6 e 3.7: Leo Slezak e Brigitte Horney. 
da decapitação atravessava assim o filme até atingir sua forma literal no episódio lunar. Na sequência da Lua, a metáfora chegava então ao seu extremo. Ali, as mulheres levavam uma existência agradável com suas cabeças separadas de seus $\operatorname{corpos}^{104}$.

O encontro entre o Barão e a selenita fora uma invenção do roteirista Kästner, o qual não existia nos relatos originais das aventuras de Münchhausen ${ }^{105}$. Nessa ocasião, ambos trocavam elogios e galanteios. Münchhausen enaltecia a aparência jovial da cabeça da mulher e ela lamentava não lhe poder apresentar o restante de sua figura, pois deixara seu corpo guardado num armário para evitar que ele cometesse tolices enquanto estivesse só e decapitado. Em meio a essa absurda conversa, um conteúdo medonho, a degolação, rendia-se ao humor negro dos chistes recheados de duplos sentidos. De tal modo que o diálogo emulava o próprio ato sexual sugerindo imagens que abandonavam a metáfora para descrever o conteúdo como tal numa modalidade de relação sexual sem sexo. O gozo era, ali, imaginar um corpo tão belo, fremente de desejo, contido num closet, mas desfrutado em palavras. Por esse meio, o tema da decapitação e sua relação com os prazeres eróticos escancarava o conteúdo sexual e o risco sempre iminente da castração. Pois o Barão seguia vivendo em plena infância justamente porque não realizara nenhum complexo de Édipo. A castração, não se processando na ordem do símbolo, ganhava,

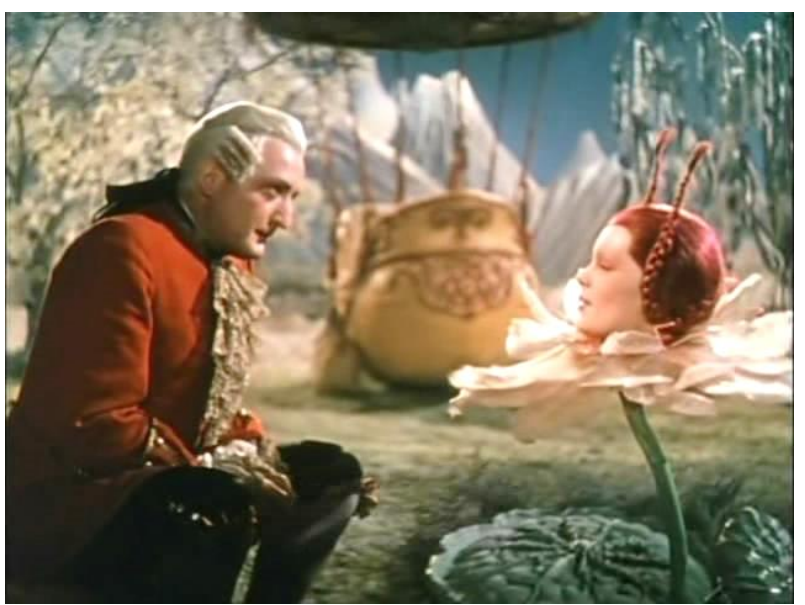

compensatoriamente, expressão real. Por esse motivo, Münchhausen se evadia de qualquer possibilidade pela qual a decapitação pudesse assumir sua forma simbólica de castração, a partir do que sua eterna fase préedípica fatalmente se encerraria.

Fig. 3.8 Hans Albers e Marianne Simson.

104 SCHULTE-SASSE, Linda. Op. cit., 313

105 RASPE, Rudolph Erich. The Surprising Adventures of Baron Munchausen. Project Gutenberg EBook, 2006, 38-40. 
No desfecho do filme, Münchhausen renunciava definitivamente à errância e à imortalidade. Admitia, por vontade própria, retornar à condição de sujeição ao tempo e ao espaço para poder morrer na sua Heimat ao lado da idosa esposa. Acompanhado por um delicado arranjo musical, o Barão pronunciava seu voto de abstinência: "A juventude eterna faz de um homem um semideus e um semihomem. Eu exijo tudo. Quero o restante". Não mais o desassossegado, mas o narcisista domesticado. Seus excessos foram contidos, sua exuberância, moralizada, seu hedonismo, constrangido e a promiscuidade deu lugar à dessexualização monogâmica. Linda Schulte-Sasse observou que esse desenlace, repleto de clichês da moralidade pequeno-burguesa, servia para pôr fim àquela sucessão de flashbacks, os quais, de outro modo, haveriam de se estender indefinitivamente. Esse desfecho politicamente correto era, contudo, insuficiente para erradicar as penetrantes impressões estéticas e ideológicas das grandes aventuras do Barão. Pois Münchhausen fora reconhecido como um notável impostor que dizia ser quem não era e quando retornava aos acontecimentos do passado nada garantia a fidedignidade de seu relato. Schulte-Sasse sugeriu que era o Barão que contava as histórias e não o Barão que as vivenciou quem mentia, pois esse estava comprometido com seu meio social, enquanto o outro somente prestava contas ao seu narcisismo ${ }^{106}$.

Na cena final, um servente, levando à mão um candelabro, desligava as luzes elétricas. O retrato do Barão emoldurado num grande quadro se agitava, inclinava-se adiante e soprava três vezes para apagar cada uma das velas. Da fumaça evanescente formavam-se as letras da palavra Ende ("fim"). Para Linda Schulte-Sasse, esse último ornamento visual indicava que era ainda o Barão que viveu suas lendas (não o que as contava e que as sacrificara para tomar seu lugar na comunidade temporal) quem ainda determinava o andamento da trama. Sua autoridade parecia então escapar aos limites do quadro para que sua imagem zombeteira permanecesse como último memento da obra aos olhos dos espectadores antes que a ilusão do filme se dissipasse e eles se vissem de volta à 
realidade da sala de exibição ${ }^{107}$.

Esse gesto dava continuidade, por meio de uma pilhéria visual, ao diálogo extradiegético que o Barão estabelecera durante o filme com a plateia. Em vários momentos - ostensivamente na sequência em que Münchhausen atravessava o céu sobre uma bala de canhão - o personagem interpelava o espectador produzindo uma situação peculiar de identificação secundária (não com um personagem, mas com os elementos do próprio dispositivo: os enquadramentos, as técnicas e os processos de fixação da instância narrativa). Por intermédio desse expediente, observou Jacques Aumont, três espaços diferentes convergem no momento do encontro olho a olho: o ambiente da filmagem, o universo diegético e a sala de cinema. O toque de olhares - o do personagem e do espectador dissipa a fronteira entre esses espaços, num artificio de presentificação pelo que o ator (presente no set, mas ausente na plateia) encontra o espectador (ausente no estúdio, mas presente na audiência). $\mathrm{O}$ artificio suspende a distância entre fantasia e realidade numa fusão momentânea, sobretudo porque o olhar do personagem atinge o espectador carregado de intenções. Por proceder de um astro consagrado e se dirigir a um meta-espectador (não a um espectador em particular, mas a todo o público), essa interpelação implica num rebatimento do real sobre o imaginário. Nesse instante, o aparato de ilusão e distanciamento do cinema clássico se desfaz. O público, então toma consciência de si e dos artifícios da técnica cinematográfica a serviço da fantasia. A sensação de privacidade voyeurística da plateia, então, simplesmente desaparece ${ }^{108}$.

Ultrapassando o limite da diégese, a história se encerrava quando o Barão, desdobrado na imagem de seu quadro, com um sorriso zombeteiro, suspirava a palavra final, Ende. Colocada imediatamente antes dos créditos finais, a cena contradizia veementemente a grandiloquência da sequência anterior, na qual Münchhausen renunciava à sua imortalidade para envelhecer ao lado da Baronesa. Pela inesperada irrupção do maravilhoso contra o esforço derradeiro de redução da trama ao chão do realismo, o contraste entre as duas sequências

107 SCHULTE-SASSE, Linda. Op. cit., 317.

108 AUMONT, Jacques, MARIE, Michel. A análise do filme. Tradução: Marcelo Felix. Lisboa: Ediçoes Texto\&Grafia, 2013, 226-7. 
sugeria que o Barão continuava sendo o mesmo mentiroso de sempre. Seu ato de renúncia não comportava, por isso, nenhuma verdade. A última tirada satírica do Barão solicitava do espectador a anuência de quem se tornou cúmplice de um segredo maledicente. Exatamente qual segredo o Barão - ou, mais precisamente, os artistas e ideólogos que providenciaram esse inesperado posfácio ao filme pretendia informar ao público com seu sorriso maroto remanesce como um objeto de estimulante especulação. A transição momentânea da forma rígida da pintura, com seu aplomb e sua dignidade barroca, para a forma flexível e móvel do personagem leva a acreditar que a admissão do princípio da realidade, da inevitabilidade da morte e do apagamento de todas as grandes vivências não devia ser levada a sério, nem sobressignificada em comentários adicionais. Sobre o que já não se pode mais falar, era mais prudente se calar.

Até ali, o Barão convidava seus espectadores para partilharem de seu Bildungsroman ("romance de formação") às avessas, solicitando que adentrassem num mundo de crenças e códigos há muito desaparecido. Münchhausen, assim, recuava a um imaginário estado pré-edípico, anterior à violenta usurpação do desejo pelo superego. Produzia uma Paideia alucinada, narcísica, pueril e encantadora. O Barão, por isso, vivia num mundo sem culpa, nostalgicamente perdido na infância. Por esse ângulo, de modo algum o filme escamoteava sua filiação ao nazismo. Pois oferecia a libertação inconsequente da pulsão de morte redimida pelo recuo a um estado de pureza pristina, onde o dolo da destruição não incidia sobre o ego, mas sobre seus objetos.

Porém, porque seu caráter estava enraizado na dinâmica do desejo de gozar a qualquer custo - uma asserção verdadeiramente obscena e coerente com a razão cínica fascista - o filme fatalmente teria de dispensar o martírio e, com ele, sua comunhão com a raça, com o povo, com a terra e com as bases da moral idealizada pelo nacional-socialismo. Münchhausen, enquanto produto da indústria cultural voltado para a satisfação do desejo, conseguiu produzir, assim, uma fantasia total, tão abrangente que englobava os anseios mais reprimidos dos seus espectadores, os coevos e os adventícios, os pró e os antifascistas. Era, por isso, uma obra que atendia à doutrina como a melhor modalidade de propaganda 
invisível: um filme de propaganda tão engenhoso que oferecia entretimento da máxima qualidade, dispensando-se, por conseguinte, do esforço de superpor à diversão qualquer conteúdo publicitário adicional. A excelência da mercadoria tornou-se, desde então, sua melhor propaganda. Dispunha ao seu público a cabal desmistificação do gozo de destruir como uma forma de autopromoção de um regime que se sustentava mediante o apelo do extermínio, da aniquilação e da terra arrasada numa guerra total. Explicitando o desejo de destruição esclarecia, então, a própria essência destrutiva da natureza humana. Uma essência baseada na substância do narcisismo, do egoísmo, do infantilismo e do escapismo, cujo atrativo, por fim, ultrapassou a órbita do seu contexto para desvelar a ampla face do desejo humano. Münchhausen não era, portanto, apenas uma imago lapidar do homem fascista. Era um retrato perfeitamente delineado da masculinidade contemporânea, emparedada nas fantasias de um resistente Peter Pan, assombrada pela iminência da castração e em permanente tensão com a perspectiva de render a polimorfia do erotismo à maldição da sublimção burguesa-patriarcal. 


\section{Capítulo 4}

\section{Titanic}

Um palácio flutuante, um prodígio tecnológico, um microcosmo da civilização burguesa, uma imagem congelada da sociedade como ela idealizava a si mesma, uma totalidade estável, definida, harmônica, funcional, singrando rumo ao futuro - nas palavras de Slavoj Žižek, o Titanic foi o ego-ideal da sociedade burguesa patriarcal. Seu naufrágio deflagrou, consequentemente, um formidável efeito de sobredeterminação simbólica. Serviu, em sua época, como uma prefiguração metafórica da calamidade que já pairava sobre a cultura europeia novecentista. As representações da tragédia produziram uma linha factual a partir da qual aquela sociedade podia antecipar imaginariamente sua iminente liquidação. Por isso, tornou-se um ponto de referência ubíquo. Aos tradicionalistas, proveu um monumento nostálgico de uma época galante, completamente depurada da vulgaridade contemporânea. Para os reformadores, propiciou uma história exemplar sobre a impotência da sociedade de classes ossificada em seus privilégios. E, aos teóricos da cultura de massa como o próprio Žižek, exteriorizou um sintoma social stricto senso ${ }^{1}$.

Desse ominoso acontecimento, Žižek enfatizou precisamente o traço sintomático da cultura. Vislumbrou nele uma formação reativa, um desconfortável significante cifrado que marcava um ponto de resistência à integração de seu conteúdo à ordem simbólica. Desse nó de significados, o Titanic, considerou o autor, encetou uma expressão exemplar do retorno do recalcado. Seu desaparecimento produziu um acontecimento chocante, porque impossível, o afundamento de um navio insubmergível. O que tornava o evento ainda mais demolidor era, então, o efeito de revide do imaginário no real - pois a tragédia ocorreu, indicou Žižek, no seu momento oportuno, quando a fantasia

\footnotetext{
1 ŽIŽEK, Slavoj. The Sublime Object of Ideology. Londres e Nova York: Verso, 2008, 75-6.
} 
já lhe tinha reservado seu próprio espaço. Quatorze anos antes do acidente, Futility, or the Wreck of the Titan (Futilidade, ou o naufrágio do Titan, 1898), um romance popular de Morgan Robertson, tratava precisamente do desastre de um indestrutível transatlântico fictício, o Titan, que colidia contra um iceberg, levando seus passageiros da alta classe e tripulantes para o fundo do mar².

Não apenas a incrível coincidência alinhavava o desaparecimento do Titanic ao sintoma traumático. O transatlântico era parte do Zeitgeist, do espírito de uma época, que alcançara seu apogeu nos idos de 1850 e, no final do século XIX, principiava a declinar. Tratava-se de uma era dourada de progresso e de relações de classe imutáveis que seria varrida pela guerra para dar lugar ao tempo das lutas sociais e dos nacionalismos ferrenhos ${ }^{3}$. $\mathrm{O}$ cinema, que imediatamente capturou a grandiloquente dimensão imaginária desse desastre, viria então a lhe acrescentar novas e peculiares perspectivas: a figuração do transatlântico como o espaço da anomia liberal e a metáfora da autonomização da máquina seguida de seu desmantelamento, arrastando tudo consigo numa gigantesca e exemplar catástrofe.

O naufrágio do Titanic foi rapidamente absorvido pelos meios midiáticos e tomado como assunto cinematográfico documental e ficcional na Europa e nos Estados Unidos ${ }^{4}$ Nos dias seguintes ao acontecimento, trechos do cinejornal da Gaumont com imagens do transatlântico e do Capitão Smith, o comandante da embarcação, entraram em circulação sob o título Titanic Disaster ("O desastre do Titanic"). Suas exibições tornaram-se uma modalidade reverencial de homenagem às vítimas. As plateias eram convidadas a cantar Nearer My God to Thee, que, de acordo com uma lenda já em voga, a orquestra tocou enquanto o navio descia ao mar ${ }^{5}$. Menos de duas semanas depois do naufrágio, projetos de

\footnotetext{
${ }^{2}$ LORD, Walter. A Night to Remember. Nova York: Bantam Books, 1977, XI-II e ŽIŽEK, Slavoj. Op. cit., 74,79 .

3 ŽIŽEK, Slavoj. Op. cit., 75.

${ }^{4}$ BERGFELDER, Tim: STREET, Sarah (ed.). The Titanic in Myth and Memory: Representations in Visual and Literary Culture. Nova York: I. B. Taurus, 2004, 7.

${ }^{5} \mathrm{O}$ que a banda do navio de fato tocou na noite do naufrágio remanesceu como um objeto de especulações. Os depoimentos dos sobreviventes reunidos por Walter Lord em 1956 não produziram nenhum esclarecimento. Muitos deles insistiram que os músicos peformaram Nearer My God to Thee, enquanto outros se recordaram claramente de que o único ritmo da noite foi o ragtime. Um deles declarou que, nos instantes finais, a banda não tocou nada, ao que contestou o
} 
dramatizações do episódio entraram nos cronogramas de estúdios alemães e norte-americanos. Em junho de 1912, surgiu a versão americana, Saved from the Titanic ("Salva do Titanic", Étienne Arnaud, 1912), que recriava com a atriz Dorothy Gibson, uma das sobreviventes do Titanic, os momentos que ela experienciou no navio. No mês seguinte, a Continental Kunstfilm estreou a primeira produção europeia, In Nacht und Eis ("Na noite e no gelo", Mime Misu, 1912). O filme de meia hora pretendia documentar os acontecimentos pela ficcionalização e, ao mesmo tempo, oferecer entretenimento com imagens grandiloquentes. Foi a primeira obra a elevar a tragédia ao domínio do espetáculo, fazendo uso de maquetes e de um navio de verdade para representar o desastre. In Nacht und Eis obteve, por isso, um grande sucesso de público, pavimentando o caminho para as sucessivas versões sonoras que fizeram do Titanic uma categoria particular do cinema catástrofe ${ }^{6}$.

Baseada na peça teatral The Berg ("A Montanha”, Ernest Raymond, 1929), o filme Atlantic, foi, ao mesmo tempo, a primeira produção de cinema falado europeia e a primeira dramatização fictícia e extraoficial da tragédia. Ainda que os nomes do navio e de seus tripulantes e passageiros fossem alterados para evitar atritos jurídicos com a White Star Line, a referência a um naufrágio causado pela colisão de um transatlântico num iceberg imediatamente identificava o navio Atlantic ao Titanic 7 . Uma segunda versão sonora do acidente teria acontecido em

operador do telégrafo, Harold Bride, um dos últimos tripulantes a encontrar abrigo num bote salva-vidas, afirmando ter deixado o navio ao som de um hino episcopal intitulado Autum. $\mathrm{O}$ comportamento dos músicos foi, doravante, tomado como medida de valor para qualificar o ethos sob o qual a tragédia seria enquadrada nas adaptações cinematográficas. A versão tricontinental dos anos 1930 produziu uma mistura de foxtrote e charleston, somente elevando o tom dramático no clímax com Nearer My God to Thee, enfatizando a galhardia dos náufragos diante da morte. Contrariamente, a versão alemã de 1943 apresentava a cena da banda como um angustiante momento de diversionismo em completo desacordo com a dimensão do acidente. LORD, Walter. Op. cit., 178.

${ }^{6}$ WEDEL, Michael. Early German Cinema and the Modern Media Event: Mime Misu's Titanic - in Night and Ice in BERGFELDER, Tim: STREET, Sarah (ed.). Op. cit., 97-108.

${ }^{7}$ Ewald André Dupont dirigiu, nos estúdios Estree de Londres, duas versões do filme, uma em alemão e outra em inglês, enquanto uma terceira, falada em francês, recebeu a direção de Jean Kimm. A trama principal envolvia um padre anglicano em crise com sua fé para a qual a catástrofe no Atlantic provia uma súbita revelação: daí, o religioso poderia oferecer conforto e amparo espiritual aos náufragos momentos antes de desaparecerem no mar. Num filme conduzido mais pelo diálogo do que pela ação, a cena final enfatizava o heroísmo, a fé, a dignidade e a serena coragem dos condenados à morte. A versão alemã estreou em outubro de 1929 como a primeira produção integralmente falada na língua nativa. Transmitida diretamente 
Hollywood em 1939. O projeto pretendia transformar o acontecimento num monumental disaster movie, incluindo o afundamento de um navio real. Contaria com um elenco exclusivamente composto por atores ingleses sob direção de Alfred Hitchcock (então um nome desconhecido na indústria de cinema norteamericana) e produção de David O. Selznick. Titanic viria coroar Selznick como o maior produtor de Hollywood logo após seu triunfo em Gone With the Wind (E o vento levou, Victor Fleming, 1939) ${ }^{8}$. A se crer nas declarações sempre contestáveis de Hitchcock, o filme deveria conjugar grandes cenas de ação com a moralidade exaltada do heroísmo inglês nos momentos finais do navio ${ }^{9}$. Fosse porque a White Star Line ameaçou lançar uma implacável batalha jurídica contra o filme, fosse porque os custos de produção se provaram impraticáveis, o projeto terminou abandonado. O elenco britânico foi transladado ao solar de Manderley e Hitchcock estreou em Hollywood com outro filme que se tornou seu primeiro hit internacional, Rebecca (Rebecca, a mulher inesquecível, 1940)10. Daí, Titanic (Herbert Selpin/Werner Klingler, 1943), a versão alemã comissionada pelo RMVP, veio a ser o primeiro filme sonoro a se referir explicitamente ao naufrágio, apresentando personagens e eventos factuais misturados à ficção para produzir uma peça de propaganda contra os ingleses e uma moralidade de guerra para os alemães.

A adaptação da tragédia fora anunciada pela Tobis Filmkunst em 1940, no auge da voga de filmes antibritânicos. Desse projeto, contudo, nada resultou. Não houve mais referências a ele até o final de 1941, quando um outro anúncio informou que a produção logo chegaria ao público. Não obstante, o filme propriamente dito somente começou a ser rodado em fevereiro de 1942, tendo à

do Gloria Palast em Berlim pelo meio radiofônico, a trilha sonora da cena da colisão foi acompanhada em várias cidades alemãs e o filme tornou-se um acontecimento nacional. $\mathrm{O}$ mesmo sucesso acompanhou o lançamento da versão inglesa em Londres no mês seguinte. PECK, Robert. Atlantic: the First Titanic Blockbuster in BERGFELDER, Tim: STREET, Sarah (ed.). Op. cit., 111-2, 114-6.

${ }^{8}$ HAVER, Ronald. David O. Sezlnick's Hollywood. Nova York; Alfred Knopf, 1980, 313.

${ }^{9}$ HITCHCOCK, Alfred. Hitchcock por Hitchcock: Coletânea de Textos e Entrevistas. Tradução Vera Lúcia Sodré. Rio de Janeiro; Imago, 1998, 230.

10 MORLEY, Sheridan. Tales From the Hollywood Raj: the British in California. Londres: Coronet Books, 1985, 188-9. 
frente o diretor Herbert Selpin e o roteirista Walter Zerlett-Olfenius ${ }^{11}$. Em setembro de 1943, quando finalmente ganhou sua estreia, os temas da arrogância britânica e de sua inexplicável hostilidade contra os alemães estavam, porém, completamente desgastados e não tinham mais nenhuma ressonância publicitária. A mensagem pró-fascista, do mesmo modo, havia se tornado dúbia, confusa e até mesmo subversiva.

Todos os filmes históricos produzidos sob o nacional-socialismo perseguiram a fantasia afirmativa da genialidade germânica, a qual, como contraparte, necessitava do contraste de seu oposto, a crueldade dos inimigos da Alemanha. Os rivais da nação foram alternativamente diferenciados em três categorias: 1) estereótipos fixados em figuras factuais, como Cecil Rhodes e Winston Churchill em Ohm Krüger (“Tio Krüger”, Hans Steinhoff, 1941); 2) atores sociais, como os "plutocratas" em Die Rothschilds Aktien aufWaterloo ("Os títulos dos Rothschilds em Waterloo", Erich Waschneck, 1940); e 3) grupos étnico-raciais tais quais os violentos poloneses de Heimkehr ("Volta ao lar", Gustav Ucicky, 1941) e os judeus nos filmes antissemitas dos anos $1940^{12}$. Oscilando entre todas essas denominações, os ingleses foram uma presença eminente que atravessou o cinema da época nazista, inspirando afetos ambíguos e oferecendo um privilegiado espelho para as aproximações contraditórias do Terceiro Reich com a Grã-Bretanha. Os filmes encenaram as inúmeras flutuações que acompanharam as instáveis relações diplomáticas entre as duas maiores potências europeias. Durante os primeiros anos do regime, nas produções cinematográficas em que sua presença foi solicitada, os ingleses se portaram como honrados cavalheiros que, a contragosto, cumpriam o desagradável dever patriótico de combaterem os alemães. A rivalidade anglo-alemã, usualmente alocada à remota Guerra dos Bôeres ou mal situada na Primeira Guerra Mundial, não dispensava a cortesia de

\footnotetext{
11 O filme de 1940 seria roteirizado por Pelz von Felinau, um sobrevivente da catástrofe, e protagonizada por Karl Ludwig Diehl. Quando o projeto reapareceu, o roteiro mudara de mãos, passando para Harald Bratt e contaria com a participação dos atores Michael Bohnen e Hilde Weissner. GIESEN, Rolf. Nazi Propaganda Films: a History and Filmography. Jefferson: McFarland, 2003, 106.

12 KALLIS, Aristotle A. Nazi Propaganda and the Second World War. Hampshire: Palmgrave MacMillan, 2005, 202, 206-7.
} 
apresentar os inimigos insulares como homens decentes e corajosos à altura de enfrentar a Alemanha13 ${ }^{13}$ Essa galante aproximação durou até 1935, quando a desejada aliança com os ingleses parecia ainda uma realidade iminente ${ }^{14}$. Entre 1936 e 1939, enquanto Hitler se beneficiava com a apatia diplomática de Londres, os ingleses nunca desapareceram por completo dos filmes de propaganda, resistindo ambiguamente nas margens das telas alemãs. $\mathrm{O}$ fracasso dos acordos diplomáticos para firmar um pacto de cooperação com a Inglaterra, porém, implicou que a gentil representação dos rivais perdesse a utilidade de propaganda. Quando a deterioração das relações transnacionais impossibilitou a aliança entre as duas nobres linhagens da estirpe ariana, os veículos de propaganda rapidamente deram voz aos ressentimentos até então recalcados pelo cálculo político. De modo que, a partir de Verräter (“Traidor”, Karl Ritter, 1936), a primeira realização antianglicana, os ingleses receberam um tratamento cada vez menos polido e mais inverídico ${ }^{15}$.

Verräter coincidia com a radicalização da diplomacia de choque hitlerista, promovendo uma aberta apologia ao militarismo germânico. Reconhecia no serviço secreto britânico o principal antagonista à política de rearmamento nazista e, por extensão, o agente obstrutor da reabilitação da Alemanha ao rol dos grandes poderes europeus ${ }^{16}$. A obra precedeu em poucos anos o apogeu dos filmes antibritânicos que se seguiu à deflagração da Operação Leão do Mar e acompanhou as campanhas de anexação alemã dos países liberais ocidentais, entre 1940 e $1941^{17}$.

\footnotetext{
${ }^{13}$ LEISER, Erwin. Nazi Cinema. Tradução: Gertrud Mander e David Wilson. Nova York: Collier Books, 1975, 95-6.

${ }^{14}$ Celebrou-se, naquele ano, um importante pacto naval anglo-germânico, mas, dali em diante, as aproximações entre os dois países tornaram-se cerimoniosas e ineficientes. Comissionado para conferenciar em Londres com simpatizantes britânicos, Joachim von Ribbentrop, o Ministro das Relações Exteriores, retornou a Berlim sem sequer costurar um pacto anti-Comintern. A abdicação de Eduardo VII, a quem Hitler considerava pró-alemão, para desposar a plebeia americana Wallis Simpson em 1936 reforçou junto ao Führer a convicção de que a Inglaterra fora cooptada numa conspiração antigermânica liderada por judeus, maçons e lobbies partidários liberais. KERSHAW, Ian. Hitler. Tradução: Pedro Maia Soares. São Paulo: Companhia das Letras, 2010, 401.

${ }^{15}$ LEISER, Erwin. Op. cit., 96 e WELCH, David. Propaganda and the German Cinema 19331945. Londres: I. B. Taurus, 2001, 219.

16 WELCH, David, Op. cit., 220-1.

17 KALLIS, Aristotle A. Op. cit., 203.
} 
De 1940 a 1942, uma série de filmes foi então colocada à disposição do público com a finalidade de fazer coincidir a ocasião de suas estreias com as expectativas em torno da campanha militar contra a Inglaterra: Das Herz der Königin ("O coração da rainha”, Carl Froelich, 1940), Der Fuchs von Glenarvon ("A raposa de Glenarvon", Max Kimmich, 1940), Carl Peters (Herbert Selpin, 1941), Mein Leben für Irland ("Minha vida pela Irlanda", Max Kimmich, 1941) e Ohm Krüger ${ }^{18}$. A Inglaterra imaginariamente concebida pelos filmes do período nazista parecia então uma esplêndida potência negativa cuja única função histórica era perpetuar as desigualdades entre os Estados europeus. Incapaz de reviver sua remota aura imperial, nada mais ela produzia no cenário internacional do que a desestabilização diplomática e a incerteza econômica entre as nações continentais ${ }^{19}$. Os ingleses assumiam, assim, o papel de capitalistas violentos e corruptos, que construíram seu império por meio de trapaças e crueldades, enquanto alguma simpatia era dispensada aos povos que caíram sob seu domínio: os irlandeses, os galeses e os escoceses. Essa distinção obrigava o cuidado de discernir os súditos da coroa, referindo-se a eles preferencialmente como "britânicos" ao invés de "ingleses" 20. E essa nova orientação, por seu lado, sustentava a convicção de que uma cisão fundamental havia fracionando a GrãBretanha em duas partes conflituosas. Uma linha divisória iria, então, distinguir os maus ingleses (envolvidos com o governo real, com o parlamento e com a elite econômica) dos bons britânicos (essencialmente as pessoas comuns do povo). De um lado, a vítima das desastradas opções dos seus líderes, o prosaico e honesto cidadão britânico, um bem-intencionado, ainda que desorientado patriota. De outro, as corrompidas autoridades do país ${ }^{21}$. Foi, por fim, nos meses que precederam a Segunda Guerra Mundial, que Goebbels lançou mão de um prolífico rótulo, plutocracia, para qualificar a casta governamental londrina.

\footnotetext{
${ }^{18}$ HULL, David Stewart. Film in the Third Reich: a Study of the German Cinema 1933-1945. Berkeley: University of California Press, 1969, 179-83, GIESEN, Rolf. Op. cit., 97-105, LEISER, Erwin. Op. cit., 103-4 e MALONE, Paul. Goebbels Runs Aground: the Nazi Titanic Film in BERGFELDER, Tim: STREET, Sarah (ed.). Op. cit.,, 2004, 122.

${ }^{19}$ WELCH, David, Ibid.

${ }^{20}$ MALONE, Paul. Op. cit.,122.

${ }^{21}$ LEISER, Erwin. Op. cit., 96.
} 
Colorindo-a com as populares tonalidades anticapitalistas, a propaganda encontrou nessa etiqueta uma inédita fonte de satisfação. Conseguiu isolar ali a fração imaginária de uma elite financeira e política corroída pela ambição e pelo egoísmo. "Plutocracia”, daí, viria a conotar um opressivo sistema de governança subterraneamente enxertado nas estruturas democráticas liberais, uma oligarquia financeira por trás das casas parlamentares, regendo em segredo a política mundial, beneficiando-se dos seus privilégios de classe e delegando às camadas sociais menos afortunadas as externalidades negativas de seus ganhos. No crescente esfriamento das relações entre Churchill e Hitler, Goebbels afirmou então que "os ingleses são os judeus entre os arianos". Do que foi finalmente derivada num mesmo horizonte cognitivo a equivalência entre os dois referentes mais perniciosos da fantasia fascista: a "plutocracia" e o "judeu". Desse emparelhamento de significantes, à já candente retórica antianglicana, adicionou-se o explosivo elemento do antissemitismo ${ }^{22}$.

A cisão imaginada pelos publicitários entre o povo e os plutocratas modulava uma fantasia doutrinária mediante a qual os espectadores podiam experimentar simultaneamente sentimentos de compaixão e ódio pelos ingleses. Não obstante, havia nessa articulação uma senha subterrânea, pela qual a Inglaterra deixava de representar a alteridade adversa da Alemanha nazista para se tornar seu duplo especular. Pois, tanto a sociedade inglesa quanto a alemã encontravam-se fraturadas por uma linha imaginária que separava seu povo - na península, cindia-a em ricos e pobres e, no continente, entre católicos e protestantes. A relação de similaridade foi prontamente reforçada quando o mesmo fantasma conjurado pela fantasia nazista para explicar a fratura social na Alemanha também veio à cena a fim de justificar a cesura na Inglaterra: o judeu ${ }^{23}$.

\footnotetext{
22 O produto mais notável desse intenso esforço de identificação com o rival inglês foi o infame Die Rothschilds. LEISER, Erwin. Op. cit., 96-7 e WELCH, David, Op. cit., 220, 222.

${ }^{23}$ A resiliência imaginária da identidade dos alemães com os inimigos ingleses sugeria que, então, subliminarmente, havia também uma cisão mais ampla, que fracionara a grande sociedade ariana europeia. Seu fator, defendiam os ideólogos nazistas, era o judeu. A finalidade de superar a ruptura e promover a integração ariana em todas as partes, então, explicava o alargamento da guerra racial nazista da Alemanha para todo o continente. Daí, a afinidade entre judeus e ingleses tornou-se um tema constante durante a guerra, de modo que cada agressão militar britânica era de imediato imputada como um gesto movido em segredo pelos judeus assentados no nicho da plutocracia. Essa linha retórica atravessou vários discursos de doutrinação emanados das
} 
Após 1942, os temas da maldita casta dos plutocratas e as mensagens antibritânicas desapareceram das produções mais prestigiosas comissionadas pelo regime, à exceção de um filme considerado unanimemente pelos críticos como contraproducente em termos propagandísticos e dramaticamente ineficaz, Titanic ${ }^{24}$.

Titanic se enquadrava no rol de projetos de propaganda para os quais, segundo as injunções de Goebbels, os artistas deveriam tomar as necessárias liberdades para retratar ficcionalmente acontecimentos históricos com a finalidade de tornar a representação artística mais fiel aos fatos do que o puro relato historiográfico - o que, em última instância, significava apor aos eventos as falsificações que se coadunassem ao nacional-socialismo ${ }^{25}$. Tal possibilidade veio a ser extensivamente explorada pelo roteirista Walter Zerlett-Olfenius, um ardoroso militante nazista para quem o desastre do transatlântico adveio como uma fascinante oportunidade de combinar propaganda pró-fascista e antibritânica com um grandioso espetáculo. Para tanto, sua imaginação concebeu como protagonista o personagem fictício Petersen, o oficial alemão que, diante do vacilante comando do Capitão Smith, intuiu a possibilidade de uma catástrofe e procurou, por todos os meios, preveni-la. Inventou, também, os variados personagens da terceira classe, os quais demonstrariam muito mais nobreza e coragem do que os abastados ingleses do pavilhão nobre. Criou, daí em diante, uma miríade de situações e dramas - um roubo de joias, uma descoberta cientifica secreta e flertes em todas as seções do navio - que terminariam interrompidos pelo naufrágio. Para reforçar a mensagem, no desfecho, Petersen, diante da Comissão de Comércio Britânica, onde se instaurou o inquérito de investigação acerca dos acontecimentos que levaram ao naufrágio, prestaria um veemente apelo de condenação à ganância dos investidores ingleses e à leniência

autoridades nazistas. De tal maneira que a Alemanha e a Inglaterra comungavam dos mesmos males e eram assoladas pelo mesmo inimigo: sua rivalidade constituía, então, uma farsa montada pelo judaísmo internacional para debilitar os arianos em todas os seus territórios. HERF, Jeffrey. O inimigo judeu: Propaganda nazista durante a Segunda Guerra Mundial e o Holocausto. Tradução: Walter Solon. São Paulo: Edipro, 2014, 105-6. 108-9, 115.

${ }^{24}$ KALLIS, Aristotle A. Op. cit., 206.

${ }^{25}$ PECK, Robert. Op. cit., 121 
das autoridades navais. E como tudo isso não parecesse suficiente, um intertítulo fecharia o filme, informando que os 1.500 mortos do transatlântico ainda aguardavam que alguma justiça lhes fosse feita ${ }^{26}$. O que, para os comentaristas e historiadores, viria a ser o derradeiro motivo de derrisão de uma obra, a qual, com tantos exageros de vilania e praticamente nenhum personagem empático, naufragava perante sua audiência muito antes que o navio começasse a afundar.

A trama iniciava com Bruce Ismay (Ernst Fürbringer), presidente da White Star Line, à frente de uma reunião de acionistas para os informar que a construção do maior navio do mundo exauriu as reservas da empresa, levou-a ao endividamento e, por extensão, jogou abaixo os valores de suas ações. Essa conjuntura, para Ismay e seus assessores, provia uma preciosa oportunidade de adquirir mais títulos da companhia a baixo custo, pois a viagem inaugural do transatlântico faria suas ações dispararem da noite para o dia e transformaria o Titanic na glória da Inglaterra.

O drama passava, disso, para o transatlântico em toda sua magnificência, atravessando orgulhosamente o Atlântico. Nele, a nata da sociedade inglesa desfilava pela escadaria do saguão nobre. Bruce Ismay e sua amante, a deslumbrante Gloria (Kirsten Heiberg) precediam a entrada da exótica e independente milionária dos Balcãs, Sigrid Olinsky (Sybille Schmitz). Daí, desciam pelos degraus da riqueza a Duquesa de Canterville (Toni von Bukovics), ao lado do seu escort, o endividado Lord Archibald Douglas (Fritz Böttger). Mais adiante, seguiam-nos o pouco pomposo Professor Bergmann (Theodor Loos) e seu assistente, Dr. Lorenzen (Just Scheu), além do trapaceiro internacional, Señor Cristóbal Mendoz (Werner Scharf). Fechavam essa rodada de luxo o banqueiro John Jacob Astor (Karl Schönböck), rico entre os ricos, e sua esposa, Lady Madeleine Astor (Charlotte Thiele).

Bruce Ismay pedia a atenção dessa esplêndida companhia para anunciar que, com suas 46 mil toneladas, o Titanic era o maior e mais seguro navio do mundo. Mas, que todos soubessem naquele momento, seria também o mais 
rápido de todos os tempos. Cruzaria o Atlântico e chegaria a Nova York em poucos dias, quebrando o recorde de velocidade na travessia do Atlântico. Para tanto, o presidente até mesmo subornara o Capitão Smith (Otto Wernicke) para acelerar o trabalho nas caldeiras. Nos bastidores, contudo, Ismay e Lord Astor disputavam a mesma coisa: elevar-se como o maior acionista da White Star Line para possuir o Titanic - pois o transatlântico não era apenas um punhado abstrato de títulos, mas, sim, uma base real de poder.

Ao Primeiro Oficial Petersen (Hans Nielsen), tudo isso parecia escandaloso e ultrajante. Considerava uma afronta que um investidor, Ismay, sobrepujasse a autoridade do Capitão e tomasse a gerência do navio. Petersen, um homem de confiança do comandante, causava desconforto entre os oficiais pela sua origem germânica. Foi ele, contudo, o único que vislumbrou com exatidão a possibilidade de uma tragédia. Ninguém lhe deu crédito quando advertia que a invulnerabilidade do Titanic era pura ficção. Ismay lhe retorquia acusando-o de conspirar a bordo com uma campanha de "pessimismo intencional" para difamar o engenho britânico e sabotar a certeira condecoração do transatlântico com a máxima honraria naval, a Fita Azul.

Enquanto isso, os corredores, o convés, os salões, os camarotes, a casa das máquinas e a ponte de comando proviam cenários para uma miríade de subtramas. Ismay se afligia porque a ruina financeira pairava sobre ele. Lord e Lady Astor se digladiavam num tedioso casamento: o banqueiro vivia apenas para seus negócios e, por isso, Madeleine se entretinha com Lord Douglas. Já o Señor Mendoz labutava para roubar qualquer coisa dos camarotes da primeira classe, ora as joias de Madeleine, ora uma fórmula secreta desenvolvida pelo Professor Bergmann. Nos labirínticos caminhos do Titanic teve início o romance da manicure Hedi (Monica Burg) e o violinista da orquestra Franzl Grüber (Hermann Brix). Na terceira classe, dois camponeses, Bobby (Peter Elsholtz) e Henry (Fritz Genschow), disputavam a atenção da licenciosa Marcia (Jolly Bohnert), parceira do Levantino (Aruth Wartan). E, no bar da primeira classe, o oficial Petersen reencontrou a mulher que frivolamente o desprezou no passado, a Srta. Olinsky: essa, então, decidiu-se a o atormentar durante a viagem com 
exigências absurdas.

Nesse cenário atravessado por dramas e disputas pessoais, a persistente advertência de Petersen de que a embarcação se arriscava em alta velocidade na zona de gelo invariavelmente caía em ouvidos surdos. Da primeira à terceira classe, todos confiavam cegamente na ilusória invulnerabilidade do Titanic. Os ricos desfrutavam luxuosos entretenimentos, enquanto os pobres vibravam com as desinibidas coreografias de Marcia, à qual até mesmo um casal de frugais protestantes, Jan (Sepp Rist) e Anna (Liselotte Klinger), não permanecia indiferente. Despreocupados, os passageiros se entregavam aos seus próprios problemas e distrações. Por isso, poucos se deram conta do fatal momento da colisão contra o iceberg.

Já era tarde, portanto, quando o Capitão Smith emitiu a mensagem de S.O.S. e deu início à evacuação do navio. Apenas à Srta. Olinsky, Petersen preveniu que não haveria botes para todos. Ciente da real conjuntura do naufrágio, Sigrid revelou sua imensa presença de espírito. Passou imediatamente a colaborar com os oficiais na organização do fluxo no convés. Heroicamente escolheu permanecer e trabalhar como um verdadeiro soldado: chegou a ser simbolicamente investida com o casaco de serviço de Petersen. Reconciliou-se com ele, renovando os votos de amor e somente deixou o navio por suas ordens.

Houve momentos esporádicos de similar nobreza, sobretudo na terceira classe. Henry superou sua rivalidade com Bobby e lhe salvou a vida. Anne recusou-se a abandonar Jan, ainda que, mais tarde, viessem a se perder um do outro. Pois logo o caos se instaurou. O navio bramia freneticamente suas sirenes, explodia seus fogos de artifício e dava espaço a momentos de violência e frenesi. A ordem rapidamente se desmantelou. Na luta pela própria vida, todos se voltavam contra todos e cada um tratava de salvar a si. Os acionistas da White Star Line ofereciam todas as suas posses por um lugar num bote. Apenas a Bruce Ismay, contudo, Petersen assegurou um salvo conduto para que, no futuro, a justiça o punisse pela catástrofe. E, quando enfim o Capitão Smith, do alto da ponte decretou "salve-se quem puder", o pânico tomou a multidão. Não havia mais pobres nem ricos, mas apenas a horda diante da morte. No momento final, 
os acordes de God save the Queen se misturaram ao clamor da destruição. Lord Astor, o Professor Bergmann, Marcia e a duquesa de Canterville pereceram com o navio. Para resgatar uma garotinha aprisionada numa cabine, Petersen se lançou às águas. Sigrid o acolheu no seu bote de onde testemunharam atônitos o desaparecimento do Titanic. Essa cena, contudo, dissolvia-se, pois toda narrativa fora o depoimento de Petersen à Comissão de Inquérito da Marinha no julgamento de Bruce Ismay. O veredito, porém, absolveu-o. Atribuiu toda responsabilidade pelo naufrágio ao finado Capitão Smith.

A trajetória do filme, da concepção ao lançamento, e o curioso itinerário que percorreu no pós-guerra fizeram dele um produto excêntrico, cujo destino não pareceu muito distinto do objeto que tomou por assunto. Os historiadores explicaram os impasses em torno da obra e seu ulterior descarte como peça publicitária pela defasagem entre a situação da produção e o momento do lançamento. Pois de fato a efetividade da propaganda nos filmes comissionados pelo RMVP invariavelmente dependia do contexto da recepção, o que colocava todos os projetos numa zona de risco situada entre o momento de seu planejamento e a conjuntura de sua estreia. As oscilações da situação política podiam, em muitos casos, destruir completamente toda intenção original de uma produção, tornando-a desatualizada ou mesmo indesejável ${ }^{27}$. A partir dessa premissa, os críticos tentaram então costurar os eventos que explicassem a peculiar carreira comercial e doutrinária do filme.

Revisando Titanic em dezembro de 1942, Goebbels não lhe atribuiu nenhum valor artístico ou político ${ }^{28}$. Contraditoriamente, em abril de 1943, conferiu-lhe a honraria máxima, o Prädikat de "Recomendado por seu valor político e artístico" para, em seguida, proibi-lo de ser lançado na Alemanha. Os motivos pelos quais o filme foi suspenso permaneceram, desde então, um tema para variadas pressuposições. Atribui-se essa decisão a uma combinação de fatores. Pesava

\footnotetext{
${ }^{27}$ KALLIS, Aristotle A. Op. cit., 202.

${ }^{28}$ MALONE, Paul. Op. cit., 127.
} 
contra a produção os misteriosos eventos que levaram à morte seu diretor, Herbert Selpin, após uma altercação com Zerlett-Olfenius e Goebbels. Críticos e historiadores, de modo geral, também defenderam que a representação do desastre se tornara real demais para uma plateia que vivia um cotidiano de bombardeios, motivo principal pelo qual justificaram o seu banimento ${ }^{29}$.

A Illustrierter Film-Kurier adiantara uma sinopse do filme bastante diversa da obra atualmente em circulação. Nela, a personagem principal chamava-se Sigrid Oole, uma dinamarquesa falsamente reputada como milionária que embarcava no Titanic onde também viajariam, rumo ao destino fatal, a nata da sociedade inglesa. Não há registro de quantas e quais alterações foram efetuadas entre a sinopse original e a obra final para a adequar ao contexto de sua estreia ${ }^{30}$. Seus analistas, não obstante, concordam que os cortes no filme promovidos sucessivamente por Goebbels e pelas comissões de censura dos Aliados após a guerra comprometeram irremediavelmente a coerência dramática da trama ${ }^{31}$. Supõe-se que uma dublagem posterior corrigiu o sobrenome da personagem de Sybille Schmitz de Oole para Olinky. Ainda assim, cenas completamente defasadas permaneceram no filme, prejudicando seu valor de propaganda. $O$ telegrama que informava Sigrid de que suas terras na região do Báltico haviam sido confiscadas e estavam perdidas, por exemplo, chegava ao público de abril de 1943 como um conteúdo repleto de significados extradiegéticos devido à reversão da guerra no Leste ${ }^{32}$.

Para recuperar parte dos altos custos da produção, o filme teve sua estreia adiada, a qual ocorreu em setembro de 1943 em Praga. Apareceu numa versão dublada em francês ao invés de legendada, com intertítulos que reforçavam o conteúdo antibritânico em novembro do mesmo ano para uma bem-sucedida temporada em Paris. Além de ser apresentado nos territórios ocupados, circulou com grande sucesso de 1943 até o final da guerra pela Espanha, Finlândia e

\footnotetext{
${ }^{29}$ COURTADE, Francis; CADAR, Pierre. Op. cit., 288, GIESEN, Rolf. Op. cit., 107, HULL, David Stewart. Op. cit., 229 e ROMANI, Cinzia. Tainted Goddesses: Female Film Stars of the Third Reich. Tradução: Robert Connolly. Roma: La Moderna, 2001, 68.

${ }^{30}$ MALONE, Paul. Op. cit., 127-8.

${ }^{31}$ HULL, David Stewart. Op. cit., 231.

32 MALONE, Paul. Op. cit., 128.
} 
Suécia ${ }^{33}$. Os alemães, contudo, somente vieram a prestigiar a obra bem depois do final da guerra. Quando, em dezembro de 1949, foi enfim exibido ao público da República Federal, houve protestos do governo inglês contra o conteúdo antibritânico, do que resultou sua suspensão em março de 1950. Contrariamente, na Alemanha Oriental, as autoridades soviéticas consideraram o material de propaganda antiliberal perfeitamente apropriado à propaganda comunista, de modo que o filme, distribuído pela Sovexport-Film, pode circular pelo bloco socialista sem embaraços ${ }^{34}$. Somente em 1955, Titanic recebeu permissão para distribuição na Alemanha Ocidental - o slogan de lançamento continha três palavras: "proibido, proibido, proibido"35.

Com pouco respaldo documental, permaneceram insuficientes os argumentos para explicar porque Goebbels suspendeu um projeto pessoal de elevado custo e alto impacto publicitário. Não havia na obra nenhuma imagem explicitamente violenta que os alemães não tivessem antes assistido nos Wochenschauen. Ao lado de alguns indícios apontados pelos seus analistas - a encenação realística de uma catástrofe naval, a significativa identificação dos espectadores com as vítimas, a dupla proscrição, dos nazistas e dos aliados, ao filme pelos mesmos conteúdos e a curiosa ressureição das cenas do naufrágio numa ulterior produção britânica, A Night to Remember (Somente Deus por Testemunha, Roy Baker, 1958) - um retrato completo de Titanic implica no reconhecimento dos elementos extremamente originais que o filme elaborou na sua construção dramática. Neles se confrontavam esteticamente aspectos ideológicos e doutrinários contraditórios que fizeram da obra uma peça de propaganda contestável porque explícita demais, não no seu conteúdo antibritânico, mas, essencialmente nas suas feições pró-germânicas.

\footnotetext{
${ }^{3}$ COURTADE, Francis; CADAR, Pierre. Op. cit., 288, GIESEN, Rolf. Op. cit., 107 e HULL, David Stewart. Op. cit., 229 e MALONE, Paul. Op. cit., 127.

${ }^{34}$ COURTADE, Francis; CADAR, Pierre. Op. it., 288, GIESEN, Rolf. Op. cit., 108 e HULL, David Stewart. Op. cit., 229-30.

35 Para detalhes adicionais do contexto de produção e recepção da obra cf. PEREIRA, Wagner Pinheiro. O poder das imagens: cinema e política nos governos de Adolf Hitler e de Franklin D. Roosevelt (1933-1945). São Paulo: Alameda, 2012, 476-83 e GIESEN, Rolf. Op. cit., 108.
} 
$\underline{\text { Alegoria heroica }}$

Os comentaristas do pós-guerra não pouparam críticas ao conteúdo propagandístico e à flacidez da mise en scène do filme. Qualificaram o resultado final como uma aventura sem clímax nem imaginação e destituída de qualquer interesse dramático. Titanic foi sumariamente descrito por Courtade e Cadars como "um teatro mal filmado". Não apenas o roteiro deficiente, mas a obviedade da propaganda pareceu-lhes constrangedora, sobretudo no que concernia aos personagens ingleses, cujas caracterizações afetadas beiravam à caricatura. Em meio a eles, o empedernido Petersen se sobressaia como um pastiche de segunda mão dos personagens interpretados por Hans Albers (embora sem o seu desembaraço) nos filmes em que o grande astro estrelou sob a direção de Herbert Selpin. O diretor Selpin, de sua parte, recebeu a maior parte das críticas por tratar o tema com insensibilidade cinematográfica, produzindo quadros rotineiros e mal encenados, desperdiçando as habilidades dramáticas de seus atores, em especial Sybille Schmitz ${ }^{36}$. A produção, concordam Tim Bergfelder e Sarah Street, ofereceu uma prova documental de como o mito do Titanic transcendia à sua funcionalização pela propaganda política. "Assim, embora originariamente pretendesse representar a hybris e a arrogância britânicas”, concluíram, “Titanic, por fim, rebatia de volta a hybris e a derrota política do regime que o comissionou"37.

Por conseguinte, a obra se situava mal até mesmo na sua manifesta preleção antiliberal. O filme, ponderou Julian Petley, perscrutava os elementos "anticapitalistas" da doutrina fascista para atender a duas finalidades.

\footnotetext{
${ }^{36} \mathrm{Da}$ curta carreira de Herbert Selpin como diretor cinematográfico não resultou nenhuma grande obra. Obteve, não obstante, sucesso considerável com os cinco filmes que realizou com Hans Albers, com quem partilhava, além das afinidades artísticas, uma franca antipatia pelo regime nazista. Após o fracasso comercial de Carl Peters, a parceria se desfez e Selpin se aproximou do roteirista Walter Zerlett-Olfenius, o qual redigiu os scripts da maioria dos filmes do diretor. Zerlett-Olfenius manejou, nessas obras, a introdução de conteúdos de propaganda nazista, aos quais Selpin assimilava com encenações frouxas e morosas. Sua associação com o roteirista e sua experiência em filmes ambientados em cenários marítimos - em especial Geheimakte W.B.I ("Ação secreta W.B.I", 1942) sobre Wilhelm Bauer, um dos inventores do submarino, credenciou-o perante Goebbels para a direção de Titanic. COURTADE, Francis; CADAR, Pierre. Op. cit., 286-8, HULL, David Stewart. Op. cit., 222-6, MALONE, Paul. Op. cit., 123 e ROMANI, Cinzia. Op. cit., 71.

${ }^{37}$ BERGFELD, Tim: STREET, Sarah (ed.). Op. cit., 8.
} 
Tencionava responder aos anseios da pequena burguesia ressentida com sua exclusão dos privilégios do liberalismo. E, ao mesmo tempo, desprestigiava ideologicamente a classe operária, apresentando-a como um simulacro mal constituído da elite. Daí, para Petley, o filme oferecia um antiliberalismo de fachada, preocupado em fabular uma fantasia de edificação do pequeno burguês, condenando o capitalismo contaminado pelos abusos dos financistas e pela concentração de renda numa casta de plutocratas e especuladores. Encenava o que autor qualificou como um "anticapitalismo reacionário" o qual pretendia fazer o liberalismo recuar para uma época passada inexistente, exceto como ideia $^{38}$.

Diante do conteúdo manifestamente retrógrado do filme, dois aspectos atraíram a atenção dos poucos críticos que, usualmente em linhas concisas, resenharam a obra: a qualidade da cenografia e a verossimilhança do naufrágio. As cenas da luta dos náufragos e do afundamento do navio combinavam efeitos especiais em maquetes com as espetaculares tomadas dos botes filmadas por Friedel Behn-Grund no porto de Gotenhafen (atual Gdynia), na Polônia. Os comentaristas do filme concordaram unanimemente que esses momentos viriam a ser o ponto culminante da trama. Identificaram nas cenas do naufrágio uma qualidade de enquadramentos e contrastes comparável aos registros documentais dos cinejornais ${ }^{39}$. A edição promovia mais cortes, fragmentando as sequências, sugerindo uma escalada rítmica que indicava a crescente extensão do desastre, tornando mais excruciantes as situações de confronto entre os

\footnotetext{
38 Esse capitalismo reacionário era a chave pela qual filmes como Der verlorene Sohn ( $O$ filho pródigo, 1934) e Der Kaiser von Kalifornien (O imperador da Califórnia, 1936), ambos dirigidos e estrelados por Luis Trenker, e também Verwehte Spuren (Angústia em Paris, Veit Harlan, 1938) e Titanic almejavam alçar o pequeno burguês à estatura de uma grandiosa burguesia. De modo que o filme rejeitava qualquer solução proletária para a crise. Pois esse setor era igualmente corrompido pelo culto à distração. Titanic produzia, consequentemente, elaborações que preservavam o status do capitalismo mesmo que às custas da destruição de tudo ao seu redor. PETLEY, Julian. Capital and Culture: German Cinema 1933-45. Londres: British Film Institute (BFI), 1979, 23, 150, 152.

39 Tamanho foi seu impacto que, em 1958, parte dessas sequências reapareceram, sem o devido crédito, em A Night to Remember, o qual também tratava do desaparecimento do Titanic. COURTADE, Francis; CADAR, Pierre. Op. cit., 287, GIESEN, Rolf. Op. cit., 108 e HULL, David Stewart. Op. cit., 231-2.
} 
personagens ${ }^{40}$. Como se carregassem a chave para elucidação da curiosa persistência da popularidade dessa malfadada peça de propaganda política, essas cenas tornaram-se, assim, o objeto mais privilegiado pela revisão historiográfica. Sua mística ganhou contornos subversivos porque elas custaram a vida do seu diretor, o que imantou o enigma do fracasso publicitário do Titanic nazista com a aura da resistência de um artista menor contra Goebbels ${ }^{41}$.

A marca distintiva da obra era prover uma representação da catástrofe pela qual se rejeitava imprimir qualquer dignidade ao acontecimento. O heroísmo, então, não se aplicava nem à mera luta pela sobrevivência, nem à pacífica resignação diante da morte. No Titanic fascista, os personagens adentravam no domínio de uma alegoria heroica para transladarem no naufrágio a realidade de uma situação sem saída. O filme se apropriava de algumas representações do transatlântico fixadas nas produções que o precederam, mas as remodelou de uma maneira ideologicamente peculiar. Apresentou uma cena de visita à casa das máquinas, mas encenada de maneira muito distinta àquela que originariamente apareceu em In Nacht und Eis. Na produção nazista, pela primeira vez, a elite descia aos subterrâneos do navio para apreciar suas

\footnotetext{
${ }^{40}$ MALONE, Paul. Op. cit., 125.

${ }^{41}$ Os interiores do navio foram construídos em estúdio de Berlim, onde as filmagens se iniciaram em maio de 1942, enquanto as cenas externas em Gotenhafen ficaram a encargo de ZerlettOlfenius, responsável pelos trabalhos de pré-produção. Os oficiais da Marinha, infelizmente, demonstraram pouco interesse em colaborar com os procedimentos, o que implicou em atrasos no cronograma e altercações entre Selpin e Zerlett-Olfenius entremeadas por insultos aos militares: "Dane-se você", berrou Selpin. "Com teus soldados de merda, teu tenente de merda na frente de teu exército de merda". Zerlett-Olfenius comunicou o ocorrido ao comandante da SS, Frank Hinkel, o qual anuiu que insultar a Wehrmacht constituía crime de traição. Transmitiu, por isso, a informação ao Serviço de Segurança e esse levou o caso a Goebbels. Selpin foi, então, conduzido por dois agentes da SS ao escritório do Ministro onde se seguiu uma violenta discussão da qual resultou o encarceramento do diretor e, no dia seguinte, a emissão de uma nota oficial comunicando seu suicídio por enforcamento. Uma semana mais tarde, um anúncio publicitário na revista Film-Kurier informou aos leitores o suicídio de Selpin na prisão, chamando a atenção contra suas "ignóbeis injúrias e proposições caluniosas em relação aos soldados e oficiais alemães do front", consideradas "um atentado à moral do exército", uma conduta particularmente execrável porque o diretor não tomara parte nem da Primeira Guerra Mundial, nem do conflito contemporâneo. Seu nome foi suspenso dos créditos e o remanescente dos trabalhos de condução das filmagens passou para outro diretor, Werner Klingler. Em 1947, uma corte de desnazificação retomou o caso e sentenciou Zerlett-Olfenius a cinco anos de prisão em campos de trabalho forçado, além do confisco de parte de sua propriedade. O roteirista, não obstante, evadiu-se secretamente para a Suíça. COURTADE, Francis; CADAR, Pierre. Op. cit., 286, 288, GIESEN, Rolf. Op. cit. 107, HULL, David Stewart. Op. cit., 174-5.
} 
engrenagens em pleno funcionamento - e essas, por seu lado, quase trabalhavam sozinhas, com pouca necessidade da labuta humana. Como a produção de 1912, a cena da despedida entre os leais operadores da casa do telégrafo foi conservada, acrescida de um arremate dramático, a libertação de um canário de sua gaiola por Jack Phillips (Karl Dannemann), o operador sênior, aos acordes de God Save the King. Já de Atlantic, Titanic preservou a cena em que a banda entretinha os tripulantes, adicionando uma atmosfera mais lúgubre que se tornaria uma das marcas dos filmes referentes ao transatlântico. A escalada do desespero ao redor dos botes salva-vidas, dramatizada a extremos na produção de 1929, receberia tonalidades ainda mais realistas, enquanto as representações do estoicismo dos oficiais e dos passageiros que permaneceram no navio até o último momento praticamente desapareceram.

A versão alemã não apenas recauchutou esses episódios, mas adicionou à encenação da catástrofe significativas representações originais. A cena da escadaria, na qual os passageiros da primeira classe são apresentados ao público e a segmentação do navio em estratos sociais, com o drama concentrado na elite apareceram pela primeira vez na versão alemã. A inédita apresentação de uma terceira classe - que, quase como uma paródia da elite, ocupava-se apenas com danças e música - também foi uma das inovações da produção. Ambos elementos, daí em diante, adentrariam no índex de cenas repetidas acriticamente em realizações subsequentes, quando a história do Titanic se tornou um atraente subgênero do disaster movie. Esses elementos repletos de implicações ideológicas remanesceram à margem das parcas análises do filme, centradas estritamente no problema político, na propaganda antibritânica e
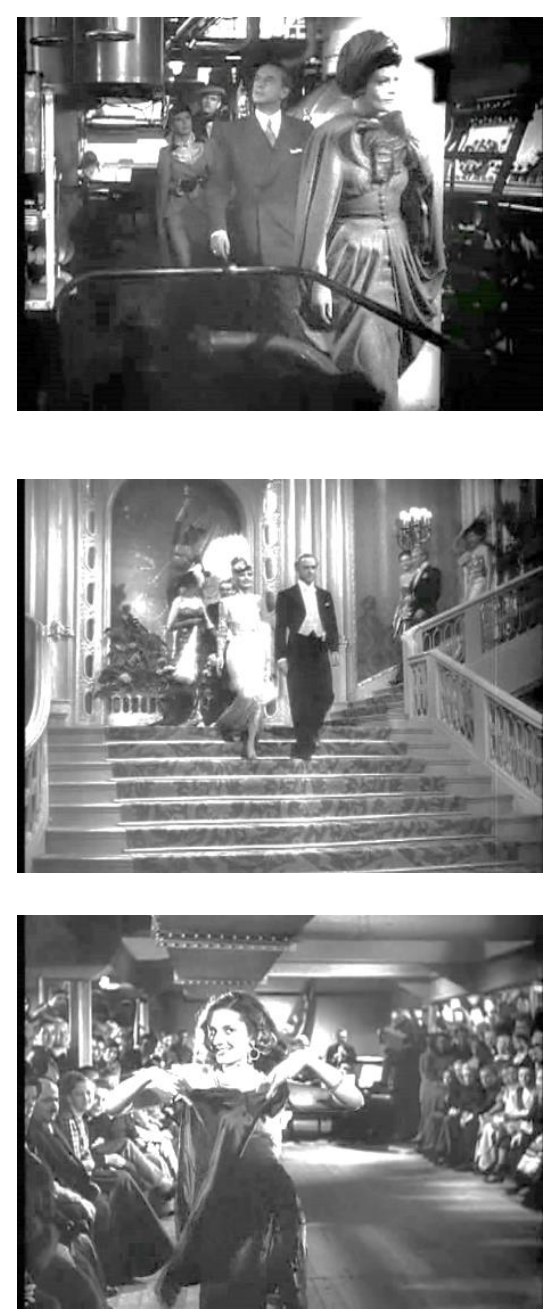

Figs. 4.1, 4.2 e 4.3: Sybille Schmitz, Ernst Fürbringer, Kirsten Heiberg e Jolly Bohnert. 
na malfadada carreira da obra. De modo que somente Julian Petley assinalou que, pela primeira vez numa produção ficcional em torno das ocorrências que levaram o transatlântico ao fundo do mar, o desastre resultava dos desesperados trabalhos de especuladores para salvarem suas ações. Disputavam-nas entre si com tanta ferocidade que lançaram o navio a uma travessia arriscada em condições extremamente desfavoráveis de navegação. Esses se tornaram, doravante, os maiores responsáveis pelo acidente e suas casualidades ${ }^{42}$.

Tomando os plutocratas como paradigma da vilania, o tema central de Titanic revolvia em torno das noções de competição, posse e perda. Tais práticas disseminavam-se em todos os ambientes do navio, descendo da primeira à terceira classe, implicando tanto as lutas por bens materiais quanto pelos afetos $\operatorname{amorosos}^{43}$. O naufrágio funcionava, então, como o gatilho que desfazia os impasses porque rompia os mascaramentos. Quando o pânico escalava a bordo, cada personagem abandonava sua aparência de autocontrole e ressurgia em sua verdadeira essência. O presidente da companhia se comportava como um egoísta covarde. A egoísta milionária dos Balcãs, ao contrário, conduziu-se com surpreendente dignidade, auxiliando os desesperados a embarcarem nos botes ${ }^{44}$. A conduta de cada um dos personagens, observou Petley, rebatia, pela qualidade ética dos atos, as proclividades étnicas de seus agentes. Por conseguinte, as poucas pessoas equilibradas, mesmo nos momentos mais agudos da catástrofe, eram indivíduos de origem nórdica. Os dois cientistas alemães, por exemplo: o Professor Bergmann, uma personalidade desprezada pela nata do capitalismo inglês por que não era rico o bastante para confraternizar com os demais milionários, recebia a morte com pragmatismo e confiava ao jovem assistente sua obra intelectual para o benefício da humanidade ${ }^{45}$. Daí, a marcação racial evolvia para a noção mais abrangente de uma comunidade de sangue superior às dotações sociais, assediada por uma conjuntura adversa cujas semelhanças com a situação da Alemanha entre 1942 e 1943 dificilmente passariam despercebidas.

\footnotetext{
42 PETLEY, Julian. Op. cit., 151.

${ }^{43}$ MALONE, Paul. Op. cit., 123.

${ }^{44}$ HULL, David Stewart. Op. cit., 231.

${ }^{45}$ PETLEY, Julian. Op. cit., 151.
} 
O Primeiro Oficial Petersen, segundo Paul Malone, constituía, assim, uma variante dos personagens que o cinema da época nazista modulou nos Geniusfilme. A partir da imagem-matriz de Adolf Hitler, surgia como um protótipo da figura do líder. Cotejava a reincidente estereotipia do homem de gênio alemão num contexto em que esse se via sozinho, movido por uma inabalável convicção, empenhado numa luta encarniçada contra a destrutiva ambição de inimigos poderosos. Mais ou menos reunidos em torno de Petersen, porque agiam como elementos de um verdadeiro Volk, cooperando para a salvação uns dos outros, Sigrid, Jan, Anna, Bobby, Henry, Franzl e Hedi superavam as distâncias de classe e lograram escapar da morte no mar. Sua vitória indicava que, abandonando o interesse pessoal, asseguraram melhores oportunidades para si do que aquelas disponíveis aos viajantes de outras raças. Esse conspícuo comportamento previa que, em tal situação, o desinteresse necessariamente deveria coincidir com o desapego. Por isso, ao final do filme, aqueles que não perderam a vida no navio, terminaram espoliados de tudo. $\mathrm{Na}$ primeira classe, Astor e Ismay viram-se sós, abandonados por suas mulheres. $\mathrm{Na}$ terceira classe, Bobby e Henry compreendiam que deveriam renunciar à sua disputa por Marcia e colaborarem para se salvarem juntos. E, mais importante no contexto histórico da obra, a ação concertada dos sobreviventes atestava que quem não demonstrara tal desprendimento e insistiu em lutar sozinho pela sobrevivência como o Señor Mendez, Marcia e o Levantino condenou-se a um destino trágico ${ }^{46}$.

Em todos esses aspectos, era impossível não reconhecer, por trás do cenário alegórico da crise do capitalismo liberal, um retrato perfeitamente delineado da própria Alemanha contemporânea e dos sujeitos que, nas condições mais adversas, buscavam produzir sua sobrevivência enquanto o país se desmanchava na guerra. Nenhum desses elementos constituíam figurações acidentais que, uma vez inseridas na narrativa, deformaram inadvertidamente seu valor de propagada para o regime. As caracterizações psicológicas dos personagens foram cuidadosamente demarcadas para produzirem modelos exemplares de 
comportamento no contexto da reversão da Blitzkrieg. Funcionavam do mesmo modo que produções como Wunschkonzert ("Pedido de concerto", Eduard von Borsody, 1940), Aufwiedersehen Franziska (Adeus, Francisca!, Helmut Käutner, 1941) e Die große Liebe ("O grande amor", Rolf Hansen, 1942) que solicitavam estoicismo, altruísmo, camaradagem e desprendimento para superação de grandes adversidades. De modo que Titanic, não por um acidente, ultrapassava o propósito de insultar os ingleses. O filme, contrariamente, promovia uma história exemplar para edificação dos próprios alemães.

Em Titanic, podem ser divisados dois filmes separados radicalmente um do outro pelo momento do naufrágio: de início, um drama de costumes e, em seguida, um disaster movie. A obra seguia a fórmula da fusão de fatos reais, elementos ficcionais e lendas acerca de acontecimentos históricos que, observou Paul Malone, já fora consagrada em inúmeras peças publicitárias precedentes. Constituía uma maneira rotineira para os cineastas acomodarem ideologicamente um evento factual em torno de dramas pessoais com ênfase no excesso e no espetáculo ${ }^{47}$. Titanic, não obstante, apresentava uma variante à equação: provia um duplo retrato da Alemanha pelo que dois contextos sociais e políticos opostos eram condicionados aos padrões de cada gênero.

Por seus elementos narrativos (dilemas pessoais, encontros e desencontros amorosos, bailes noturnos) e seus conteúdos cênicos (ambientes faustosos e elegantes, ricamente iluminados, enfatizando detalhes e ornamentos para sugerir entretenimento e conforto), a primeira parte, o drama de costumes, modelava um sistema representação que remetia, ao imaginário de desregramento da Alemanha weimariana. As figuras femininas - Sigrid, Gloria, Madeleine, Marcia - dominavam as situações com seu apelo erótico e sua frivolidade. Após a colisão com o iceberg e a transição do melodrama para o filme catástrofe, a encenação adquiria uma tonalidade mais realista - a qualidade quase "documental" observada pelos críticos - e processava um reajuste no comportamento dos personagens. Doravante, o elemento masculino tendia a prevalecer, ao ponto de Sigrid terminar parcialmente travestida como um oficial do navio. Com seus

${ }^{47}$ MALONE, Paul. Ibid. 
gestos de grandeza e suas mesquinharias, todos passavam a agir conforme os modos fixados nos filmes de promoção da campanha militar alemã. Daí que, nesse segundo segmento, a representação da República cedesse lugar a uma evidente figuração da Alemanha nazista, com seus códigos de conduta e seu ethos militar próprios à adversa conjuntura contemporânea, metaforicamente representada pelo naufrágio.

No âmbito do melodrama, o filme adotava, então, o formato consagrado em Grand Hotel (Grande Hotel, Edmund Goulding, 1932). Lançava mão de um cenário de luxo onde transitavam grandes e pequenos personagens. Esses viviam seus dramas particulares que se encadeavam devido sua presença simultânea no mesmo espaço. Daí, uma estética de excesso visual dominava o espetáculo. Os cenários abundavam em elementos indicando ostentação e magnificência, renunciando à caracterização da atmosfera marítima em prol de um ambiente que alternava esplendor, confinamento e claustrofobia.

Esse panorama franqueava à cena uma variedade de possibilidades dramáticas para apresentar a existência social dos personagens na chave da moralidade burguesa e fixada pela atitude individualista. O drama se concentrava sobretudo nas aventuras de Sigrid Olinsky cortejada por Bruce Ismay, enquanto secretamente flertava com Petersen ${ }^{48}$. Assim, a existência privada dos plutocratas era apresentada num registro tão detestável quando suas negociatas financeiras. Ismay deixava para trás sua opulenta amante e labutava para seduzir Sigrid, pretendendo custear com a fortuna dela suas aventuras financeiras. Lady Astor, ostensivamente ignorada pelo marido, que admitia apreciar mais seu dinheiro do que a beleza da esposa, flertava com o decadente Lord Douglas. Esse, aparentemente, fazia do serviço de escort de mulheres endinheiradas seu modo de subsistência. Nessas ocasiões, as interpretações empostadas dos atores, tomadas pelos historiadores pelo seu valor de face, produziam uma paródia da vilania. As expressões de desdém de Kirsten Heiberg e Charlotte Thiele, a afetação pomposa de Karl Schönböck e a vulgaridade déclassée de Ernst Fürbringer não escondiam a intenção caricatural. Compunham

${ }^{48}$ MALONE, Paul. Ibid. 

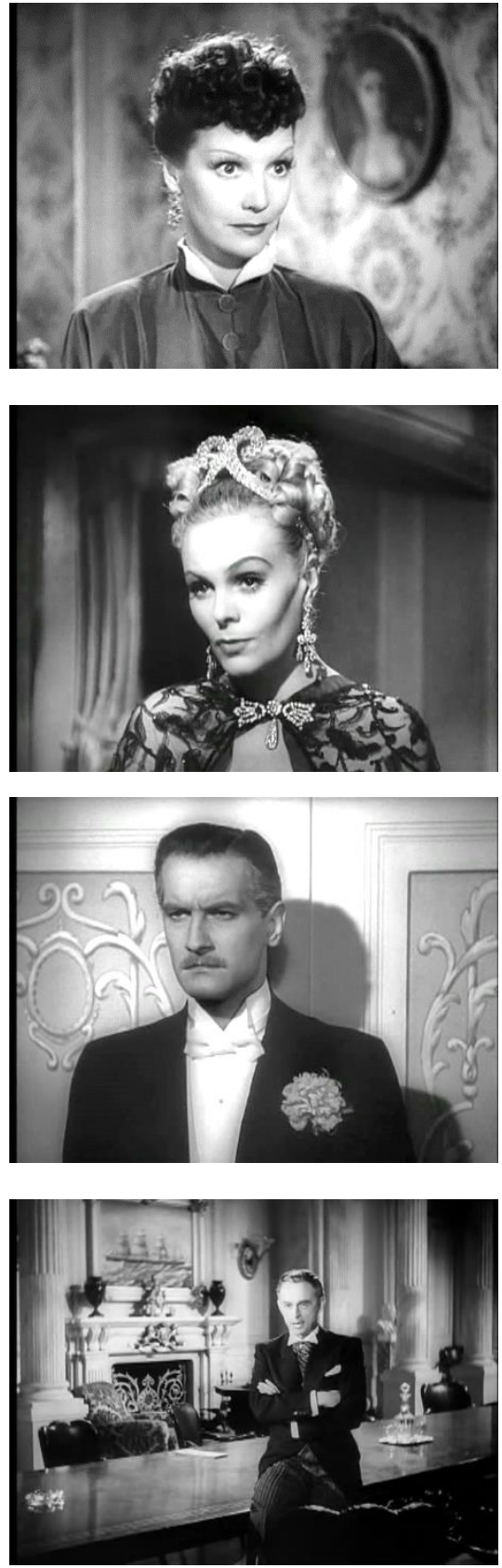

Figs. 4.4 , 4.5, 4.6 e 4.7: Kirsten Heiberg, Charlotte Thiele, Karl Schönbock e Ernst Fürbringer. um retrato da elite como uma grande mascarada, voltada ao ridículo e ao riso. O que tornava mais gritante o contraste com a segunda parte do filme, quando as máscaras despencavam e os personagens saiam do domínio da estereotipia para adentrarem no realismo catastrófico. Todos esses momentos se assentavam a um drama de costumes e serviam bem à propaganda antibritânica tanto pela crítica aos valores liberais, os quais produziam condutas desregradas, quanto pela frouxidão do sistema inglês de poder, do que resultava a grande catástrofe. Mas, como foi assinalado, havia entre os ingleses e alemães traços de uma identidade constituída imaginariamente, estabelecida em torno das fraturas racial e social, pelo que ambos comungavam de um mesmo assento simbólico. Esse conteúdo transparecia no filme que, ao remeter o drama à imprevidência dos ingleses, referia-se indiretamente à história recente de cisões políticas seguidas de crises terminais da própria Alemanha.

\section{Disaster movie}

Resultando de uma dupla ruptura - com a natureza e com a homeostase narcísica primária -, a cultura, observou Žižek, funciona como uma formação reativa desdobrada a partir de um trauma originário. Forma, assim, um núcleo resistente que escapa à simbolização ${ }^{49}$. Uma das chaves do desejo acionada num

49 ŽIŽEK, Slavoj. Op. cit., XVIII, XXIX. 
filme catástrofe é precisamente a provisão de uma fantasia voltada à destruição do sintoma fixado pela cultura. As produções vinculadas ao disaster movie promovem enredos nos quais uma dada ordem passa por um cataclismo, depois do que a situação original jamais poderá ser restabelecida na sua totalidade primeva. Após a consumação do desastre, todos os sintomas da cultura se dissipam. Em seu lugar, surge uma sociedade que regrediu à condição de indiferenciação originária. Os sistemas que apartavam o homem do meio natural foram decompostos, o que, em termos de articulação do desejo, significa o regresso a um estado de narcisismo primário, para o qual já não subsiste nenhum obstáculo imposto pela civilização. O cinema catástrofe perscruta o desejo de retorno à origem, antes do trauma da castração, numa fantasia que encena persistentemente a pulsão de morte em pleno movimento ${ }^{50}$.

Titanic recuava a um evento em que um sistema de classes fora, em questão de poucas horas, completamente dissipado, dando lugar ao fenômeno da massa. Essa, relegada a si mesma, degenerou numa horda de desesperados, acelerando sua própria destruição, franqueando a sobrevivência apenas aos mais aptos. Num filme antibritânico, essa representação nem remotamente provia algum índice de similaridade histórica com a Inglaterra contemporânea para operar como uma alegoria do decadentismo liberal. O filme remetia a processos traumáticos para os quais a fantasia da catástrofe advinha com a finalidade de desatar o nó dos sintomas sociais que faziam daquela sociedade encerrada no microcosmo do transatlântico uma comunidade de degenerados vivendo existências sem sentido. Essa fantasia rescendia não ao sistema políticoeconômico inglês, mas recuava ao mal sepultado passado alemão e ao trauma da experiência democrática liberal weimariana.

A política, segundo Agamben, explicita a medialidade que torna visível o meio como tal ${ }^{51}$. Uma noção claramente conforme à encenação do segmento melodramático de Titanic. Nas disputas do banqueiro Douglas contra os acionistas da White Star Line, dos oficiais com seus superiores e dos passageiros

\footnotetext{
50 Para considerações sobre a pulsão de morte, cf. nota 54 do Capítulo 3.

${ }^{51}$ AGAMBEN, Giorgio. Meios sem fim: notas sobre a política. Tradução: Davi Pessoa. Belo Horizonte: Autêntica Editora, 2015, 107.
} 
entre si em todas as classes, o filme tornava visível os processos de circulação das decisões e a instabilidade do meio onde o poder flutuava. "O Titanic é uma garantia tangível, " dizia Lord Astor no clímax de sua guerra acionária contra Bruce Ismay. “Garantias tangíveis criam o poder". O tema de fundo que movia o filme adiante era precisamente a luta pelo poder concentrada na disputa por um espaço físico, o transatlântico. Esse funcionava como uma sociedade em miniatura, segmentada em classes, sob a frouxa liderança do Capitão Smith e paralisada pela disputa dos plutocratas. O meio social estava, em todos os seus estratos, consumido pelo decadentismo, absorvido numa cultura de entretenimento e hedonismo. A imagem que a obra desenhava era então, ipsis litteris, uma descrição da República de Weimar vislumbrada pelos ideólogos fascistas.

No seu idioma cifrado, os nazistas se referiam aos quatorze anos da República parlamentar como o Systemzeit, a "época do sistema", implicando nesse rótulo a imagem de um tempo estéril, um período de destituição, esvaído de dinamismo, uma etapa estacionária, a qual o nacional-socialismo adveio, então, para sua superação ${ }^{52}$. O System não se definia nem como um regime de distribuição de poder, nem como um princípio de governo, mas simplesmente como uma memória da paralisia política e da fragmentação ideológica ${ }^{53}$. Consagrada após uma escandalosa derrota por meio de uma concordata desonrosa, a República de 1919 elevou ao poder uma classe governamental inepta, que nunca contara com qualquer simpatia da sociedade. Sua política pacifista soava subserviente e vergonhosa, uma traição aos que se autodenominavam nacionalistas e conspiravam abertamente contra o novo regime democrático. Foi, por isso, entrevista por muitos como um tempo de frustração e engodo, uma época de ódios disseminados, um renovado front de lutas para os radicais desterrados dos campos de batalha ${ }^{54}$. Esse mal-estar se

\footnotetext{
52 ARENDT, Hannah. The Origins of Totalitarism. Nova York: Harcourt, 1997, 260.

${ }^{53}$ KLEMPERER, Victor. LTI: a linguagem do Terceiro Reich. Tradução: Miriam Bettina Paulina Oelsner. Rio de Janeiro: Contraponto, 2009, 169-73.

${ }^{54}$ ELIAS, Norbert. Os alemães: a luta pelo poder e a evolução do habitus nos séculos XIX e XX. Tradução: Álvaro Cabral. Rio de Janeiro: Zahar, 1997, 169-71, 177, 203 e SLOTERDIJK, Peter. Crítica à razão
} 
distribuía homogeneamente entre radicais de direita e os comunistas, dois grupos que pregavam o comprometimento político e o sacrifício pessoal em prol do bem comum. Ambos, por isso, comungavam na crítica contra tudo que subsidiava a exaltação do hedonismo na época republicana: a apologia à liberdade sexual, o fortalecimento do movimento feminista e o florescimento de variadas subculturas sociais com suas vanguardas radicais ${ }^{55}$.

A República produziu, assim, uma imagem na qual os doutrinadores fascistas podiam assimilar simultaneamente a decadência política à degeneração do meio social numa dupla crise: a decomposição da Kultur e a corrupção da Zivilisation $^{56}$. Pois o período de Weimar inaugurou uma época de ataque contra os paralisantes efeitos da tradição. Fez da Kultur o campo minado dos embates ideológicos, o que tornou o choque traumático das vanguardas mais profundo e permanente na Alemanha do que alhures. A burguesia alemã, que havia admitido com amargura o sistema parlamentar, temendo alternativas mais radicais como uma república bolchevista, interpretou a súbita politização da sua Kultur como o maior dos insultos. Pelos meios de representação no cinema e no teatro, os burgueses se viram diante de um inédito espetáculo: a entrada em cena de uma legião de gangsteres, caftens, prostitutas, onanistas, pederastas e fetichistas, invocados das profundezas do submundo para protagonizarem a narrativa daquela nova Alemanha - moderna, alienada, falida e corrompida. Skandal tornou-se, então, a palavra-chave da crítica artística ${ }^{57}$. Tornou-se também

cínica. Tradução: Marco Casanova, Paulo Soethe, Pedro Costa Rego, Maurício Mendonça Cardozo, Ricardo Hiendlmayer. São Paulo: Estação Liberdade, 2012, 546, 551-2.

${ }^{5}$ EVANS, Richard J. The Coming of the Third Reich. Nova York: Penguin, 2003, 126, 128-9, GAY, Peter. A cultura de Weimar. Tradução: Laura Lúcia da Costa Braga. Rio de Janeiro: Paz e Terra, 1978, 154-6 e LIONEL, Richard. A República de Weimar, 1919-1933. Tradução: Jônatas Batista Neto. São Paulo: Companhia das Letras, 1988, 167-72.

56 À Kultur pertenciam os estratos médios da população, economicamente produtivos, mas politicamente excluídos. Nela, a burguesia alemã reconhecia seus campos de verdadeira existência social: a religião, a ciência, a filosofia e as artes. Daí que na Kultur subjazesse uma inerente indisposição contra a atividade política, assunto exclusivo do Estado, o humilhante demarcador da falta de autonomia dos burgueses. O comportamento político e civilizado, a Zivilisation, passou então a se referir ao ambiente da polidez, à presunção dos governantes, às boas maneiras, à hipocrisia aristocráticas, à diplomacia e ao fingimento dos políticos. ELIAS, Norbert. Op. cit., 119-28 e GAY, Peter, A cultura de Weimar. Tradução: Laura Lúcia da Costa Braga. Rio de Janeiro: Paz e Terra, 1978, 108.

57 Por conseguinte, muitos experimentaram com um sentimento de alívio a violenta erradicação da praga vanguardista na primavera de 1933. Interpretaram, naquele acontecimento, não um 
o denominador de uma cultura social voltada ao narcisismo, ao exibicionismo e ao imediatismo. “No colapso de todos os valores, uma espécie de loucura tomou posse particularmente dos círculos burgueses que, até então, tinham sido inabaláveis na sua probidade", constatou Stefan Zweig na Berlim dos anos 1920, onde entreviu visões dignas de Bosch. "Por toda Kufürstedamm, jovens rapazes maquiados desfilavam e nem todos eram profissionais: todo estudante universitário queria ganhar alguns trocados e, nos bares mal iluminados, podiam-se ver funcionários públicos e financistas ternamente cortejando marinheiros bêbados sem nenhuma vergonha"58. Aos olhos de seus comentaristas, a República veio assim ao mundo como bordel a céu aberto. "No Hotel Eden, onde eu residi em Berlim, o café-bar era enfileirado com vagabundas de luxo" recordou-se a atriz Louise Brooks. "As garotas baratas caminhavam lá fora na rua. Na esquina, ficavam as moças com botas anunciando flagelação. Agentes de atores cafetinavam para as senhoras em apartamentos de luxo no quarteirão bávaro. Cambistas de corridas automobilísticas no Hoppegarten arranjavam orgias para grupos de atletas. O clube noturno Eldorado exibia uma excitante linha de homossexuais vestidos como mulheres. No Maly, havia uma opção entre lésbicas femininas ou em fraque. A luxúria rugia nos teatros" 59 .

Toda essa coreografia de mascaramentos chamava a atenção de seus observadores pela artificialidade do exibicionismo sob o qual revolvia a vaidade profundamente ferida de um país derrotado. “Era a necessidade de

\footnotetext{
retrocesso conservador, mas a almejada restituição da Kultur à sua condição pristina. Foi a emancipação da cultura que os setores ilustrados da Alemanha, a princípio, saudaram na revolução nazista. A aliança num pacto autoritário chegou a esse setor como a única, senão desesperada alternativa de recomposição de sua envergadura social perdida. Segmentos mais amplos da sociedade, não obstante, rapidamente superaram as últimas e nebulosas marcas que discerniam Kultur e Zivilization. Predispuseram-se a uma nova modalidade de espetacularização da política: a teatralidade do líder, o coruscante fascínio das marchas uniformizadas, a música, os efeitos de luz, os cenários a céu aberto onde a massa se oferecia como espetáculo. Os palcos das esmagadoras assembleias do Partido transformaram-se, então, no caldeirão da nação levando a politização da Kultur a níveis nunca vislumbrados durante a República. STROBL, Gerwin. The Swastika and the Stage: German Theatre and Society, 1933-1945. Cambridge: Cambridge University Press, 2009, 18-9, 21, 23-4, 27, 35.

58 ZWEIG, Stefan. The World of Yesterday. Tradução: Anthea Bell. Nebraska: University of Nebraska Pres, 2011, 316.

59 BROOKS, Louise. Lulu in Hollywood: Expanded Edition. Minneapolis. University of Minnesota Press, 2000, 97.
} 
autoafirmação, à qual ninguém se subtraía”, diagnosticou Elias Canetti. "Quem não quisesse ser esquecido deveria ser visto. Isso valia para todas as classes, todas as camadas, até mesmo para os pedintes que, no Café Romanisches, conservassem intacto o personagem que representavam, e não admitissem qualquer deturpação"60. Não se tratava, portanto, de um tempo dourado de liberdade e ousadia, mas de desespero e confusão. "Sempre achei aqueles anos sobrecarregados e cheios de tensão - uma época esquisita, em que tudo parecia ser feito com exagero e meio doidamente, “, lembrava-se Albert Speer. “'Dourado' seria o último adjetivo que eu escolheria para descrever tal década" 61. Na expressão lapidar de George Grosz, a República de Weimar era, pois, como "um mundo negativo, com uma espuma colorida na superfície"62.

“A República de Weimar faz parte dos fenômenos históricos junto aos quais é possível estudar da melhor forma possível como a modernização de uma sociedade procura ser paga”, subsumiu Peter Sloterdijk. “Trocam-se conquistas técnicas pelo mal-estar crescente na não cultura: alívios civilizatórios pelo sentimento de ausência de sentido"63. Uma descrição que, mutatis mutandis, poderia vir apensa como sumário crítico de Titanic. As múltiplas situações de adultério, a libertinagem desenfreada em todos os níveis sociais do navio e, sobretudo, a promiscuidade entre os interesses públicos e privados mimetizavam as estruturas sociais do período liberal alemão. Referiam-se a um imaginário nativo, muito distante da cena político-social inglesa, contra a qual o filme pretensamente investia. A malaise que se esparramava nos corredores e desvãos do navio era inconfundivelmente germânica.

O transatlântico, porém, não constituía apenas um cenário para alegorizar a sociedade liberal, mas, também, o espaço que explicitava a política como um meio de trânsito por onde uma decisão procurava se assentar. E, assim, oferecia o liberalismo e suas modalidades decisórias como a alteridade negativa do

${ }^{60}$ CANETTI, Elias. Uma luz em meu ouvido: história de uma vida 1921-1931. Tradução: Kurt Jahn. São Paulo: Companhia das Letras, 2010, 297.

${ }^{61}$ SPEER, Albert. Os diários secretos de Spandau. Tradução: Guilherme da Nóbrega Cesarino. Rio de Janeiro: Editora Arte Nova, 1995, 420.

62 SLOTERDIJK, Peter. Op. cit., 551.

${ }^{6}$ SLOTERDIJK, Peter. Op. cit., 515. 
nazismo $\mathrm{O}$ filme organizava bastidores para disputas as quais, no microcosmo do navio, reproduzia o padrão de lutas políticas condicionadas pelo modelo de Estado que a doutrina fascista, na interpretação de Carl Schmitt, definia como binário, ou seja, cindido, de um lado, pelo aparato administrativo estatal e, de outro, pela sociedade civil ${ }^{64}$. Mesmo um apologista dos regimes democráticos como o jurista Hans Kelsen reconhecia que esse modelo, consubstanciado pelo sistema parlamentarista alemão, na percepção da opinião pública, era tal qual um corpo estranho e mal situado entre a efetivação da ação estatal e os anseios populares. Pois a representação popular se efetuava indiretamente, numa instituição que nem sempre abarcava toda diversidade social. Daí que, do ponto de vista da sociedade, o Reichstag não representava, mas produzia uma ficção de representação65.

Na Alemanha, essa estrutura binária fora abolida em março de 1933 por uma série de medidas - notadamente a suspensão das atividades partidárias, a proscrição do comunismo, a cessação da liberdade de opinião e a concentração dos poderes no Executivo - que, em suma, significaram a suspensão da Constituição de 1919. Em lugar do modelo binário, o nacional-socialismo introduziu a estrutura triádica, baseada no Estado, no povo (definido como o setor etnicamente homogêneo da sociedade organizado de forma corporativa) e o Partido, a organização central da estrutura que comandava as demais instâncias, obstruindo o conflito entre elas e mantendo-as dentro das linhas do movimento 66 .

Precisamente faltava à fábula do poder encenada no transatlântico uma representação dessa terceira estrutura, a instituição partidária, que deveria operar como um poder moderador, administrando os interesses conflituosos. Daí, na sua estrutura binária, as disputas dramatizadas em Titanic principiavam como uma guerra na plutocracia e descambavam, no momento da crise, em pura

\footnotetext{
${ }^{64}$ SCHMITT, Carl. State, Movement, People: the Triadic Structure of Politica Unity (1933) / The Question of Legality 1950). Tradução Simona Draghici. Corvalis: Plutarch Press, 2001, 10.

${ }^{65}$ KELSEN, Hans. A democracia. Tradução: Ivone Castilho Benedetti, Jefferson Luiz Camargo, Marcelo Brandão Cepolla, Vera Barkow. São Paulo: Martins Fontes, 2000, 114.

66 SCHMITT, Carl. Op. cit., 3-7, 12, 17-8, 38, 43.
} 
anarquia. Naquela situação extrema de excepcionalidade, a autoridade política desvaneceu e a crise se transformou numa catástrofe.

"Soberano é aquele que decide sobre a exceção", decretou Carl Schmitt em 192267. Pois, na situação de normalidade constitucional e jurídica, a ordem vigente coincide com a norma, de modo que nenhuma instância social pode provar sua força na hierarquia do poder. Contrariamente, norma alguma se aplica à exceção, pois ali se suspende toda ordem existente. Daí que a situação da crise instaura a exceção e essa revela o lócus da decisão em sua absoluta pureza ${ }^{68}$. Durante a submersão da República de Weimar na crise, Carl Schmitt atinou, por meio desse axioma, que aquela situação criava sua própria legalidade - porque a soberania decidia a exceção, a república liberal era uma exceção sem soberania. E assim também era o Titanic. Nos termos da ficção, o Primeiro Oficial Petersen solicitava do Capitão Smith a interrupção do tráfico de influências e a concentração do privilégio das decisões no círculo do oficialato. Titanic servia, então, como um caldeirão de representações para atestar que, no momento da exceção, inexistia num sistema binário, parlamentar e liberal a autoridade capaz de decidir sobre ela. $O$ filme se dispunha como um estudo sobre a substância do poder informada numa fantasia catastrófica pela qual os pilares do ideário liberal - a racionalidade, o individualismo e o materialismo - provavam-se inúteis para responder à crise. Enquanto peça de propaganda, Titanic, então, atualizava a memória de um período crítico da história alemã para, assim, revalidar o nacional-socialismo como instrumento de organização do poder. A contrapartida dessa rememoração era a aposição da moralidade e da conduta nazista à situação do naufrágio. De tal maneira que a disputa monopolista, os embates para centralização do poder num espaço instável e a impotência da modernidade tecnológica contra o meio hostil, nos meados de 1943, rebatia sobre o passado weimariano a contemporaneidade e a atualidade do próprio nazismo.

\footnotetext{
${ }^{67}$ SCHMITT, Carl. Political Theology: Four Chapters on the Concept of Sovereignty. Tradução: George Schwab. Chicago: University of Chicafo Press, 2005, 5.

${ }^{68}$ SCHMITT, Carl. Op. cit., 12-3.
} 
Nos seus momentos finais, o Titanic tornou-se não apenas um palco de disputas e de despedidas tumultuosas, mas, foi também o cenário de gestos grandiosos, os quais incidiam na peculiar atração do imaginário fascista pela solidariedade que os homens de caráter dispensam aos seus iguais. Por isso, o professor Bergmann, ciente de que dispunha de poucas chances de escapar, desistia de sua vida para assegurar melhores oportunidades de resgate ao seu assistente, Lorenz e, assim, garantir que sua fórmula também sobrevivesse. Da mesma maneira, a despedida dos operadores do telégrafo Phillip e Bride (Heinz Welzel) marcava um ponto elevado do drama. A cena, de acordo com Paul Malone, adquiria uma tonalidade que oscilava entre a qualidade paternal e o afeto homossocial. Tornava-se verdadeiramente melodramática no momento em que Phillip libertava seu canário de estimação e esse voava sozinho rumo à escuridão ${ }^{69}$. Nessas circunstâncias, continuou Malone, ao invés de promover satisfação sádica, o drama produzia comiseração pelo destino das vítimas. E esse sentimento não se confinava aos leais tripulantes e aos náufragos desamparados da terceira classe, mas se distribuía por todos os setores sociais do navio. De tal modo que mesmo o ataque à plutocracia financeira e à administração corrompida se revertia em simpatia. No momento da catástrofe, os pérfidos ingleses tornaram-se frágeis e não despertavam a expectativa de vingança, mas, sim, piedade pela sua miséria. Tornavam-se, ao seu modo, personagens grandiosos porque se viam diante de uma situação extrema e fatal. A Duquesa de Canterville descia ao convés quando já não havia mais botes e ali se percebia sozinha, confusa e desamparada, sem meios de se salvar. Lord Astor, igualmente, reconhecia tarde demais seus erros e, ao fim, também se encontrava diante da morte só e arrependido. Os gestos do Capitão Smith, por seu lado, rescendiam contrição e remorso enquanto se despedia dos oficiais e subia à ponte para informar à multidão que todos cumpriram seu dever ${ }^{70}$.

Abrindo o cenário a diversas intrigas que se entrecruzavam, na relação de amor e ódio entre Sigrid e Petersen subjazia uma das chaves ideológicas da obra

\footnotetext{
${ }^{69}$ MALONE, Paul. Op. cit., 126.

70 MALONE, Paul. Op. cit., 127.
} 
pelo que o filme comutava um drama crítico acerca da Alemanha pré-fascista numa moralidade nazista para tempos catastróficos. Quando o pânico irrompia a bordo, cada personagem abandonava sua aparência de autocontrole e ressurgia em sua verdadeira essência. Na primeira classe, o presidente Ismay se comportava como um egoísta covarde. Gloria e Madeleine deixavam para trás seus parceiros para se salvarem a qualquer custo. Mas a fútil e leviana milionária dos Balcãs, ao contrário, conduziu-se com surpreendente dignidade. Aclamada unanimemente pelos críticos do pós-guerra pela sua caracterização da frívola Sigrid Olinsky, na primeira parte do filme, a atriz Sybille Schmitz concentrava sobre si a parcela mais expressiva do drama. David Stewart Hull foi o primeiro a observar que, de sua memorável entrada em cena, descendo as escadarias do salão nobre, envergando uma vistosa peruca negra, em diante, ela governava todas as cenas em que aparecia71. Sua personagem não constituía apenas um meio de distração romântica, mas um compósito de elementos referentes à identidade de gênero sexual, de classe social e de atitude moral que se tornariam o eixo de significação pela qual o filme deveria veicular sua mensagem doutrinária. A conduta dessa personagem, que abandonava seus pertences e sua segurança para servir ao interesse coletivo no momento em que tudo se desfazia ao seu redor, era em tudo coadunada à situação de 1942-1943, quando o filme deveria chegar ao seu público alemão.

$\mathrm{Na}$ alternância entre seus mascaramentos, a imagem cambiante de Sigrid Olinsky encontrou um perfeito registro na persona cinematográfica de Sybille Schmitz. Considerada como uma atriz de grande alcance dramático, capacitada a representar um amplo arco de emoções, da inocência adolescente ao delírio da necrofilia, sua carreira floresceu em grandes filmes na época weimariana, especialmente Tagebüch einer Verlorenen (Diário de uma garota perdida, G. W. Pabst, 1929) e Vampyr (O vampiro, Carl Theodor Dreyer, 1932)72. No período nazista, foi categorizada pelas revistas de cinema como uma das atrizes alemãs mais aptas a

\footnotetext{
${ }^{71}$ COURTADE, Francis; CADAR, Pierre. Op. cit., 1972, 287 e HULL, David Stewart. Op. cit., 2312.

72 ROMANI, Cinzia. Op. cit., 67.
} 
encarnar a sedutora e perigosa mulher cosmopolita ${ }^{73}$. Porém, por motivos não precisamente estabelecidos, Goebbels desapreciava a atriz, o que reduziu suas oportunidades na indústria de cinema. Não obstante, ela estrelou grandes sucessos como Fährmann Maria ("Balseiro Maria”, Franz Wysbar, 1936) e Der Tanz auf dem Vulkan ("Dança sobre o vulcão", Hans Steinhoff, 1938). Seus enormes olhos castanhos e os ângulos abruptos de seu rosto, muitas vezes apropriados para filmes fantásticos, opinou Cinzia Romani, não proviam a aparência racial apreciada pela doutrina fascista. Tinha traços estrangeiros e uma fisionomia problemática, turvada por uma crescente fragilidade emocional, que a tornou propensa a crises de depressão e a inclinações suicidas, qualidades acentuadas devido à dependência de narcóticos. Como lhe faltavam os caracteres germânicos que a qualificasse como uma saudável heroína romântica, terminou, então, consignada ao papel de mulheres problemáticas e ambivalentes. Do que resultaram algumas caracterizações marcantes do cinema alemão na época nazista: Georg Sand em Abscheidswalzer (A valsa do adeus, Géza von Bolváry, 1934), a chantagista Gloria Cheveley em Ein idealer Gatte ("Um marido ideal”, Herbert Selpin, 1935) e uma passional espiã russa em Hotel Sacher (Hotel Sacher, Erich Engel, 1939) ${ }^{74}$.

Em Titanic, Schmitz representava a mulher que, devido a seus privilégios de classe social, tivera o caráter corrompido pelo luxo e pela riqueza - porém, em circunstâncias mais favoráveis, poderia ter merecido o amor de um homem como

\footnotetext{
${ }^{73}$ MALONE, Paul. Op. cit., 124

74 Ao lado da estrela Renate Müller (cuja morte misteriosa em 1937 foi atribuída, direta ou indiretamente, à Gestapo por sua resistência em sustentar relações cordiais com Hitler e pelo seu envolvimento com um amante judeu) e do ator Joachim Gottschalck (que, em 1941, recusou-se a entregar a esposa judia e a filha à custódia da Gestapo, assassinando ambas e se suicidando em seguida), pela sua morte prematura e misteriosa em 1955 (aparentemente resultante de uma overdose de pílulas contra a insônia, o que não afastou a hipótese de suicídio), Sybille Schmitz tornou-se uma referência nos debates acerca das relações da indústria cultural alemã com o regime nazista. Foi a primeira personalidade cinematográfica, após o Manifesto de Oberhausen, a prover elementos à cultura de massa para os complexos processos de negociação da Alemanha democrática com seu passado fascista. Serviu, assim, como inspiração a Rainer Werner Fassbinder, o qual a considerava uma das maiores atrizes cinematográficas de todos os tempos, a realizar uma biografia romanceada de sua vida, Die Sehnsucht der Veronika Voss (O desespero de Veronica Voss, 1981). HULL, David Stewart. Op. cit., 174-7, ROMANI, Cinzia. Op. cit., 68, 119-21e TÖTEBERG, Michael (org.). Rainer Werner Fassbinder: a anarquia da fantasia: ensaios, anotações de trabalho, conversas e entrevistas. Tradução: Sonia Baldessarini, Clóvis Marques, 1988, 195-6
} 
Petersen. Seu verdadeiro caráter, contudo, o oficial não fora hábil o suficiente para discernir. Pois ela sempre surgia em cena sobredeterminada pelas marcas do excesso visual. Adentrava no filme carregada de signos: a lustrosa peruca negra e os figurinos opulentos, transitando

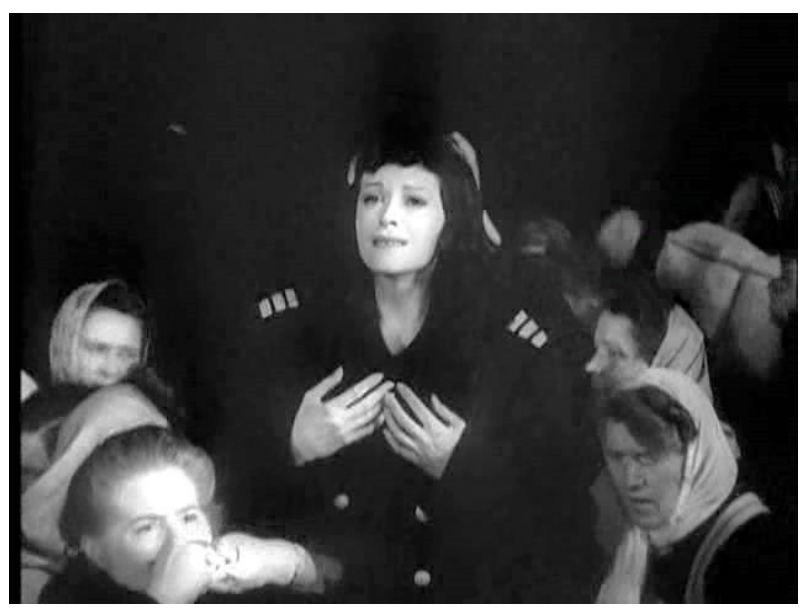

Fig. 4.8: Sybille Schmitz .

fleumaticamente em ambientes de luxo. O que tornava mais significativa sua ulterior transformação numa voluntária da tripulação. Essa mutação se processava por meio de uma transição marcada pela troca de figurino. Sua personagem abandonava a vaidade no momento em que todos os demais se rendiam ao desespero. Passava a trabalhar junto aos tripulantes, auxiliando-os na organização dos embarques de passageiros nos botes salva-vidas. Nesse momento, dispensava seu imaculado casaco de hermínia para proteger a manicure Hedi do frio, um gesto que demarcava sua nova posição - de vilã, iniciava sua trajetória de ascenção a heroína ${ }^{75}$.

Observando-a a distância, Petersen se surpreendeu com seu desprendimento e sua atitude de solidariedade. Por isso, oferecia-lhe seu casaco de oficial. Ela não apenas era, então, uma voluntária. Estava, agora, investida da dignidade militar. Tornara-se diferente da dama acetinada que frequentava a plutocracia britânica. De uma mulher rica se transfigurara num soldado. E essa metamorfose era um ponto marcante nas caracterizações cinematográficas de Sybille Schmitz. Para acompanhar seu amante em uma arriscada aventura no Atlântico, ela foi travestida como um piloto de aeronaves em F.P.1 antwortet nicht

\footnotetext{
${ }^{75}$ Manifestações adicionais de nobreza reforçavam seu novo status, como o célebre enquadre que representava sua descida num bote. Lançava, então, um desesperado olhar para Petersen. Sua imagem desaparecia deixando a marca da máscara facial de seu sofrimento numa representação extremamente expressiva, uma mistura de emoções: desespero, dúvida, descrença, fatalismo e prontidão para a morte. Uma caracterização tão macabra que desafiava o naturalismo para produzir uma imagem do real por trás da encenação, a qual, para Cinzia Romani, justificaria, per se, a repulsa de Goebbels contra o filme. ROMANI, Cinzia. Op. cit., 68.
} 
("F.P.1 não responde", Karl Hartl, 1932). Em Abscheidswalzer sua personagem, Georg Sand, trajava roupas masculinas e agia como um homem quando lhe convinha, pelo que preservava sua identidade social feminina apartada da condição de subserviência imputada ao seu gênero sexual. E, na sua caracterização em Trenck, der Pandur (“Trenck, o Pandur", Herbert Selpin, 1940), renunciava ao status de princesa para vestir o uniforme dos Pandures, os mercenários que combateram pelo Império Austro-húngaro, e, assim, aderir à causa revolucionária de seu amante em. Nesses momentos, suas personagens adentravam num domínio dialético de gênero. A mascarada masculina esvaziava sua identidade de mulher para a preencher com um simulacro dos emblemas da virilidade. Abandonando os adereços que demarcavam seu caráter feminino e tornando-se dessexuada parecia irresistível aos homens. Somente assim Petersen podia admirá-la e a amar. Pois a função simbólica do uniforme com o qual a investira era precisamente funcionar como um objeto de transição pelo qual dela se exorcizava o apelo sensual, comutando-o em valor viril.

Uma variedade autores vinculou a agressividade do homem inclinado ao fascismo a uma complicada condição de homossexualidade mal inumada. A libido recalcada desses sujeitos ressurgia no seu comportamento por meio de impulsos brutais que demandavam sua libertação na forma de destruição ${ }^{76}$. Wilhelm Reich considerava que os tipos masculinos mais violentos são incapazes de estabelecerem relações eróticas balanceadas com mulheres porque sua agressividade caminha junto com o esforço de represar sua inclinação homossexual. O impulso homoerótico recalcado evolve, assim, para um "espírito de camaradagem" e para a disposição de vivenciar coletivamente a obediência e a submissão. Faz aflorar impulsos sádicos ocultos sob a fachada do esprit de corps, da honra, da disciplina e das experiências partilhadas junto aos "parceiros de armas"77. Adorno acompanhou esse raciocínio, implicando a violência da masculinidade fascista como a face manifesta da homossexualidade latente e mal

\footnotetext{
${ }^{76}$ THEWELEIT, Klaus. Male Fantasies: Volume 1:Women, Floods, Bodies, History. Tradução: Stephen Conway, Erica Carter, Chris Turner. Minneapolis: University of Minnesota Press, 2010, 54.

77 REICH, Wilhelm. The Mass Psychology of Fascism. Nova York: Farrar, Straus and Giroux, 1985, 192.
} 
acomodada pela repressão. O transbordamento dessa virilidade era, ao seu ver, o sintoma pelo qual esses homens negavam sua afeminação. Dai, a hostilidade dirigida ao outro reforçava os laços homossexuais que os mantinham afetivamente integrados ${ }^{78}$.

Klaus Theweleit sugeriu uma leitura alternativa à noção prevalente da "homossexualidade reprimida" comutada em chauvinismo para estabelecer um princípio próprio à personalidade do homem identificado com o fascismo: o enrijecimento psíquico. Theweleit observou que os corpos desses homens foram mecanizados, esvaziados de suas emoções, endurecidos pela dor. Seu desejo era, então, purgar tudo que remanescia de feminino em si para se fazerem invulneráveis, id est, livres da produção dos desejos. Nos seus corpos enclausurados e dessensualizados, a sexualidade revertia a um estágio de permanente erradicação do desejo ${ }^{79}$. Esse estado, que apartava o homem dos perigos do contato, era fixado num processo de educação coletiva, o qual reunia indivíduos anônimos em grandes massas sólidas. Essas se tornavam cantões seguros contra a dissolução dos seus egos. A partir das unidades e das colunas militares que coletivizavam o esforço individual de preservar a rigidez do ego, os mecanismos de identificação afetiva eram então orientados de um soldado a outro. Posto que não evoluía para uma fixação erótica, seus afetos se exprimiam, então, por uma variedade de objetos intermediários partilhados entre eles: o povo, a pátria, a cidade ou a terra natal, o comandante, os demais camaradas, os subordinados, a tropa, as armas, as atividades esportivas, os animais (particularmente os cavalos) e os uniformes da companhia. Esses objetos funcionavam então como o receptáculo da libido homossocial, mas prescindiam da possibilidade problemática do ato sexual propriamente dito. Pois o objeto, ao

\footnotetext{
78 ADORNO, Theodor W. Interesse pelo corpo in ADORNO, Theodor W.; HORKHEIMER, Max. Dialética do Esclarecimento. Tradução: Guido Antonio de Almeida. Rio de Janeiro: Zahar, 1985, 193 e ADORNO, Theodor W. Minima Moralia: reflexões a partir da vida lesada. Tradução: Gabriel Cohn. Rio de Janeiro: Beco do Azougue, 2008, 42

79 THEWELEIT, Klaus. Male Fantasies: Volume 2: Psychoanalyzing the White Terror. Tradução: Stephen Conway, Erica Carter, Chris Turner. Minneapolis: University of Minnesota Press, 2010, XIX.
} 
mesmo tempo em que formalizava a afeição homossocial, deserotizava a relação $0^{80}$.

Nos tempos de guerra, os uniformes tornaram-se objetos intermediários privilegiados e adquiriram uma conotação especial. Eram o invólucro simbólico que protegia um ego em permanente estado de disputa com o mundo exterior. Curzio Malaparte se impressionava que, por baixo deles, jaziam homens sem vitalidade. Não era, pois, de si próprios que emanava a potência do terror, mas da dignidade de sua armadura. "Sua pele real é seu uniforme", escreveu Malaparte. "Se os povos da Europa soubessem da nudez flácida, indefesa e morta escondida pelo cinza esverdeado do uniforme, o exército alemão não poderia aterrorizar nem mesmo os mais indefesos povos" 81 . De modo que a armadura externa não se prestava apenas à defesa contra as pulsões libidinais interiores, mas, também, ofereciam uma carapaça a egos debilitados contra as ameaças externas. Era uma barreira ao desejo que protegia e nivelava todos os homens numa mesma situação de permanente suspensão erótica. A virilização de Sigrid em Titanic, então, incidia num padrão de fantasia pela qual o uniforme que ela recebia instaurava um obstáculo à sua sexualidade porque a transformava simbolicamente num homem como Petersen. O que eles partilhavam não era mais a atração libidinal, mas o senso de participarem numa mesma missão, colaborando na organização da horda dos náufragos. Esse novo status suspendia seus interesses privados, mas os unia num laço mais estreito. Ambos se tornavam parte da mesma máquina que totalizava tudo ao seu redor e pertenciam, naquele momento extremo, a uma realidade comum a qual os assimilava num mesmo e contínuo movimento de amparar e resgatar um Volk desnorteado.

A metáfora do movimento era um leitmotiv que atravessava Titanic promovendo importantes marcações ideológicas e doutrinárias. O movimento, no filme, alternava-se entre o espaço e os personagens. Padrões específicos de

\footnotetext{
80 THEWELEIT, Klaus. Male Fantasies: Volume 1: Women, Floods, Bodies, History. Tradução: Stephen Conway, Erica Carter, Chris Turner. Minneapolis: University of Minnesota Press, 2010, 57-61. ${ }^{81}$ MALAPARTE, Curzio. Kaput. Tradução: Cesare Foligno. Nova York: Nyrb, 2005, 388.
} 
composição, de organização dos recintos, de enquadramento e de iluminação discerniam os ambientes sociais sempre frementes, ocupados por passageiros e tripulantes circulando de um lado a outro. Neles, a despeito das diferenças ambientais, ricos e pobres padeciam da mesma modalidade de alienação pela qual renderam seus destinos à cobiça de alguns plutocratas e ao desgoverno de uma autoridade inepta. Daí que a sobriedade de Petersen fosse visualmente marcada por uma estética de iluminação natural, conferindo a muitas de suas cenas uma aura de veracidade documental que contrastava com as demais figurações do segmento melodramático do filme. Ao contrário de Sigrid, Petersen jamais cambiava sua figura - era, em todas as ocasiões, apresentado em seu uniforme de serviço, o que o tornava uma presença estática, constante, não importando a vertiginosa oscilação do drama quando esse evolvia do idílio para a calamidade. E essa, por sua vez, era sinalizada a partir do instante em que o navio colidia com o iceberg e parava de se movimentar. De modo que a catástrofe coincidia com o momento de paralisia.

Sob o crivo doutrinário fascista, a crise da democracia era precisamente a paralisia. Suas engrenagens funcionavam mal, nunca chegavam ao seu limite, entravam em fadiga e, por fim, simplesmente paravam de trabalhar. Não se comparavam ao nazismo em movimento perpétuo, como uma máquina em marcha. Pois máquina e movimento coincidem, de tal maneira que aquilo que nunca para, não pode jamais afundar.

Bewegung, "movimento", observou Victor Klemperer, constituiu o substantivo quintessencial do nazismo, seu denominador vital. O nacionalsocialismo se definia precisamente como um "movimento". Daí que os atributos daquilo que se move cristalizaram-se na retórica do regime, passando a conjurar um campo semântico próprio. Sugeriam a importância do que se mostrava dynamisch ("dinâmico). Inferiam a reiterada característica da Tendenz ("tendência), ou seja, o ímpeto irrefreável vitoriosamente direcionado a um objetivo. Seguir a tendência do movimento, portanto, converteu-se num 
imperativo da revolução reacionária fascista ${ }^{82}$. Daí, a metáfora da obstrução à ação servia para marcar a transição do drama da representação da crise do sistema weimariano à crise da ditadura de Hitler. Para tanto, o filme se apropriava da mitologia moderna da máquina autônoma, orgânica e infalível.

O Titanic era, simultaneamente, uma máquina de poder e uma máquina dos prazeres. Nesse segundo domínio, o aparelho produzia aos ricos os cenários perfeitos para seu exibicionismo, o que explicava a inédita inclusão de uma cena descritiva na escadaria, onde cada milionário era delineado pela grandeza de suas posses. Aos pobres, também nunca antes conjurados numa representação do transatlântico, essa máquina franqueava um ambiente livre do rigor do trabalho, no qual podiam imitar a elite, ocupando-se de prazeres transitórios, música e festas. Em meio à exultação democraticamente distribuída, somente Petersen retinha a necessária qualidade de repressão tão apreciada pela doutrina fascista. Graças a isso, ele não se deixava lograr pela mistificação daquele gigantesco cenário talhado para produzir um regime diversionista, agradável tanto à elite quanto ao operariado, mas inútil no momento da crise.

Pela representação dos espaços, os filmes do período nazista, assinalou Sabine Hake, formalizavam uma crítica reacionária contra a modernidade que incidia tanto sobre as inovações arquitetônicas quanto contra o progresso tecnológico. A reprodução de recintos cênicos elegantes, as linhas do design moderno, as fachadas translúcidas, as curvas dinâmicas, os saguões elegantes e os ambientes graciosamente decorados, de acordo com Hake, subsumiam os piores atributos do liberalismo: o vício consumista, o hedonismo, o decadentismo e o vazio da luxúria. O estilo moderno era associado com os gostos da classe alta, preocupada com prazeres fúteis, muito usualmente indexados nos termos do feminino, do individualismo e da promiscuidade. Do que resultava uma

\footnotetext{
82 A noção de movimento estendeu-se num largo vocabulário colateral. Incluía Sturm ("ímpeto", "assalto") para caracterizar as SA (Sturmabteilungen, "divisões de assalto") e o Reitersturm ("assalto de cavalaria"). Na esteira do movimento, a língua exultava a velocidade das schlagartige Aktionen ("ações fulminantes) e da Blitzkrieg ("guerra relâmpago"). E quando o movimento ameaçava escapar ao controle, não era interrompido pela estase, mas pelo contramovimento. Então, à triste memória do entorpecimento na Stellungsfront ("frente de trincheira") da Primeira Guerra Mundial, impôs-se o beweglicher Verteidigungskrieg ("guerra de defesa em movimento"). KLEMPERER, Victor. Op. cit., 342-5.
} 
complicada relação entre a solicitação antimoderna e os objetos materiais da modernidade dispostos à curiosidade escópica dos espectadores. A crítica contra o moderno disputava com uma estética que glamurizava, enfatizava e fetichizava objetos luxuosos. Se o texto manifesto das obras rejeitava esses objetos, paradoxalmente, no nível subliminar, eles adentravam no círculo do desejo para responderem a uma cultura de consumo que solicitava tais e mais prazeres ${ }^{83}$.

Por isso, em Titanic, o espaço cenográfico do navio presumia não apenas o ambiente ideal para uma variedade de subtramas, mas, sobretudo, a própria titularidade dramática. Do princípio ao fim, cada detalhe do cenário era fragorosamente perscrutado pela câmera num explícito exercício de voyeurismo onde se produzia a revelação proibida do luxo, dos negócios escusos e das traições eróticas. Nos seus corredores, personagens surgiam e desapareciam. Os recintos abriam-se em outros recintos onde as histórias se misturavam. O labirinto cênico correspondia visualmente ao labirinto das tramas costuradas entre si. O espaço físico do navio interagia com os personagens por uma sonoridade peculiar que, por assim dizer, dava voz ao espaço - a música da orquestra, a banda da terceira classe, o grito das sirenes, os cristais e os metais retinindo, os fogos explodindo, a sonora violência da água. Nesse drama, portanto, o índice Titanic implicava em algo mais complexo do que um lugar. Era, em sentido lato, uma realidade autônoma, não apenas um lócus, mas um sistema sujeito à sua própria emanação vital, portanto irredutível aos esforços de dominação humana. Trazia consigo a natureza da Coisa e a potência da pulsão de morte às quais somente Petersen, imune aos encantos dessa grande cena (e também a qualquer dispersão do feminino em geral) conseguia perscrutar ${ }^{84}$. $\mathrm{O}$ que fazia do navio uma metáfora complexa, que condensava as duas posições da máquina - prazer e poder - numa mesma representação para formular a imagem de um Estado desgovernado rumando em direção ao caos.

Uma tradição cultivada no cinema weimariano (Metrópolis proveu seu primeiro paradigma) e revivida no período nazista vinculava o culto à máquina

\footnotetext{
${ }^{83}$ HAKE, Sabine. Popular Cinema of the Third Reich. Austin: University of Texas Press, 2001, 54-5, 58-9, 67.

84 Para referências à Coisa, cf. nota 124 do Capítulo 1.
} 
aos efeitos corruptivos da modernidade. Filmes como Gold (Ouro, Karl Hartl, 1934) e Der Tunnel (“O túnel”, Curtis Bernhardt, 1933) associavam o advento de tecnologias revolucionárias a efeitos socais devastadores. Quando não colocado a serviço da comunidade e da nação, o progresso tecnológico fatalmente descambava em ruína para todos. Essas obras problematizavam um conflito imanente entre o conhecimento técnico e o poder. Ofereciam a solução conciliatória do retorno dos proventos do saber aos valores do nacionalismo, condição sine qua non para afirmação positiva da modernização. Do contrário, a tecnologia se transformava num monstro indomável. A máquina, então, presentificava uma entidade desvirilizada, inacessível à autoridade, e, por conseguinte, investia-se das mesmas estereotipias aplicadas à mulher. Estigmatizadas pela perspectiva masculina, ambas revelavam uma natureza refinada, elegante, voluntariosa, indócil, insensível, possante e perigosa ${ }^{85}$.

Na história cultural europeia, uma longeva tradição artística transladou o imaginário referente à tecnologia como uma força autônoma e magnificente perante a qual a vontade humana se curvava. Sua primeira forma significativa foram os Maschinenmenschen, as máquinas humanas, os androides. Quando surgiram na literatura dos Setecentos não se discernia nessas criações uma identidade sexual. No século XIX, observou Andreas Huyssen, essas figuras passaram a personificar potências mórbidas, capazes de deflagrar o caos e a destruição. Ao mesmo tempo, começaram a se diferenciar sexualmente: adquiriram os contornos de mulheres ${ }^{86}$.

O peculiar tema da mulher-máquina costurava, nesse contexto, a fantasia masculina que produzia uma conexão simbólica entre o corpo e a sexualidade feminina com os misteriosos mecanismos que faziam um aparelho tecnológico funcionar. Nessa figura coalesceram natureza e técnica, formando uma imagem híbrida pela qual se dava a ilusão de um mecanismo autônomo que operava sob o governo de uma vontade própria. Ali se imaginava uma conexão entre a natureza (a vida orgânica, então tratada como um grande mecanismo biológico)

\footnotetext{
${ }^{85}$ HAKE, Sabine. Op. cit., 53, 55-6.

86 HUYSSEN, Andreas. After the Great Divide: Modernism, Mass Culture, Postmodernism. Bloomington, Indiana: University of Indiana Press, 1986, 69.
} 
e a máquina (um artefato da cultura e da tecnologia que rivalizava com a natureza na criação da vida). A partir do que a figura da mulher-máquina adentrou em fantasias alteritárias cujo destino final era o exorcismo do espírito que habitava o aparelho, culminando na sua apoteótica morte. Disciplinar a máquina não equivalia apenas a domesticá-la pela punição, mas trabalhar para sua completa erradicação. A máquina, então, perfazia um circuito multiforme do desejo: desejo de criação, desejo de controle, desejo de violência e, por fim, desejo de morte ${ }^{87}$.

Havia, em Titanic, uma flutuação pela qual o gênero da máquina, a princípio, alinhava-se ao feminino. A versão alemã indexou ao cânone dos filmes voltados à catástrofe do transatlântico a inédita cena da catábase à casa das máquinas, a qual se tornaria, doravante, um clichê do gênero. Por razões triviais, um grupo de aristocratas e endinheirados esnobes resolve, nessas cenas, prestar uma visita às caldeiras para apreciarem os mecanismos internos da grande máquina que os circunda. Encontram, nas profundezas do navio, um cenário infernal, habitado por homens suados, labutando sob uma tóxica nuvem de carvão flamejante. Ausente nas versões cinematográficas anteriores, a visita à casa das máquinas produzia um episódio aparentemente insignificante na trama. Sigrid desafiava as diretrizes de Petersen e organizava uma turnê vespertina junto a um grupo de vips da primeira classe. Ali, as máquinas pareciam funcionar sem a necessidade do empenho humano. Mais tarde, porém, os operários eram instados por um oficial a trabalharem mais para o Titanic não perder seu ímpeto. Pelo contraste entre a personalidade dos ricos e a falta de identidade dos carvoeiros, assinalavam-se uma série de representações: as diferenças de classe, a frivolidade da elite, a distinção do comportamento dos oficiais e dos passageiros. A cena provia, igualmente, um momento de identificação de Sigrid, na sua condição de femme fatale, com as entranhas violentas do aparelho: ambas presenças coincidiam pela sua personalidade autônoma, pela independência de seu mecanismo de ação e pela sua força motriz que, sem um governo masculino, fatalmente se encaminhava ao desastre.

${ }^{87}$ HUYSSEN, Andreas. Op. cit., 68-9, 75-6. 
Havia nessas sequências também um investimento fetichista na mecânica e no movimento das peças metálicas. As cenas permitiam um vislumbre dos secretos mecanismos da máquina num passeio visual pelas suas engrenagens. Provia um contato sensorial com seus ruídos e a sugestão de uma cavidade fremente e quente, imprópria ao olhar e, por isso, mais atraente à escopia. Nesse sentido, Titanic levava além a relação estática de paixão e horror pelas máquinas, coincidindo com uma tendência distinta ao cinema weimariano que se tornaria popular nos filmes do período nazista nos anos 1940. Em realizações como Stukas ("Bombardeiros", Karl Ritter, 1941), Besatzung Dora ("Tripulação Dora”, Karl Ritter, 1943) e U-Boote westwärts ("Submarinos rumo ao Oeste", Günther Rittau, 1941) a potência triunfal dos aparelhos mecânicos se tornava o centro do espetáculo. Do mesmo modo, o compartilhamento deles pelos soldados aprimorava a camaradagem masculina. A destreza no manejo dos seus aparatos tecnológicos de destruição aguçava as qualidades viris dos personagens. As máquinas de guerra recebiam, nessas obras, um tratamento diferenciado. Funcionavam tal qual os uniformes oficiais, os objetos intermediários que Klaus Theweleit reconheceu como veículos para a expressão dos afetos homossociais fixados na base da identidade fascista. Não havia, por isso, um amor mais puro e sincero do que o do homem pela sua máquina.

Titanic promovia, então, uma interação entre o sujeito, a máquina e a tecnologia. Porque servia ao poder e ao prazer, era o transatlântico uma máquina total. Todos os seus ambientes, seus salões e camarotes, suas escadarias e corredores tornavam-se objetos da atenção da câmera como se ali ela encontrasse um sistema orgânico no qual a fachada deslumbrante era subsidiada pelo estado da arte da tecnologia. Por esse meio, o filme rebatia, no plano da fantasia, um modelo doutrinário que assimilava o decadente ao moderno. Desenhava a célebre síntese imaginária que o nazismo promovia para justaposição da tecnologia com a reação nacionalista à qual Jeffrey Herf nomeou modernismo reacionário. Por esse rótulo, Herf qualificou o peculiar arranjo de discursos, metáforas e expressões que promoviam a conciliação dos componentes tecnológicos da modernidade provenientes da Zivilisation ocidental no tecido da 
tradição do nacionalismo orgânico da Kultur. Assim, da Kultur os modernistas reacionários pretendiam reter as virtudes raciais do Volk alemão contra as influências destrutivas do cosmopolitismo liberal e materialista. Do que derivaram a notável conclusão de que a tecnologia deveria ser sequestrada do âmbito da Zivilisation para servir à Kultur. Quando definiu a mentalidade da nova ordem como um "Romantismo de aço", Goebbels produziu uma imagem sintética de uma sociedade que chegara à modernidade tecnológica sem se imaginar conspurcada na etapa das revoluções liberais. Por isso, ela podia funcionar como uma máquina perfeita - nela, a Zivilisation metálica revestiu as paixões da transcendente Kultur com um impenetrável verniz platinado ${ }^{88}$.

O Titanic conjurado na versão cinematográfica alemã pretendia, então, subsumir, na imagem da máquina total, uma imago contemporânea do Estado alemão pela qual propugnava a revalidação dos laços de solidariedade comunal em torno do pacto autoritário. Essa interpretação é fortemente subsidiada pela típica perspectiva simbólica que congregava, no imaginário fascista, as noções de "máquina" e "inundação".

Klaus Theweleit reconheceu a peculiaridade de caráter do homem fascista nos esforços de evasão defensiva contra qualquer forma de conexão emocional imediata e um translado dos afetos para grandes temas abstratos - a nação, o destino da raça, a política - numa permanente negação daquilo que singulariza as relações de um sujeito com o outro. A personalidade de um indivíduo inclinado ao fascismo, por isso, cruzou a tênue fronteira que diferenciava o sujeito dos objetos: sua subjetividade se confundiu com a objetividade. Theweleit reconheceu, então, processos de dissolução de barreiras pessoais e distúrbios nas relações objetais dificilmente redutíveis à noção corrente do ego consagrada pela psicanálise freudiana. Na personalidade do homem tendente ao fascismo, segundo o autor, o ego subsistia de maneira fragmentária e funcionava fora da

\footnotetext{
88 HERF, Jeffrey. Reactionary Modernism: Technology, Culture and Politics in Weimar and the Third Reich. Cambridge: Cambridge University Pres, 1998, 1, 35, 40, 46, 195-7.
} 
lógica edipiana. Não participava de nenhuma fixação originária ao corpo materno. Por conseguinte, a fantasia da fusão libidinal laborava num padrão de tensão entre desejo e temor pelo qual o fascista somente podia conceber a experiência do prazer objetal sob estados de extrema intoxicação alucinatória e mediante a violência, a explosão, a destruição e a aniquilação do objeto ${ }^{89}$.

A díade medo/desejo de fusão e a dissolução dos limites do ego pelo apagamento dos meios de diferenciação com o objeto aproximavam a personalidade do homem inclinado ao fascismo à dos sujeitos psicóticos. Como esses, eles também não estabeleciam relações objetais estáveis e, por isso, experimentavam momentos de alucinação e ausência nos quais percebiam seu ego se fragmentando, sendo inundado por pressões externas, contra as quais reagiam com padrões mecanizados de ataque e defesa. Tais mecanismos, continuou Theweleit, assumiam uma relação dual que integrava a violência da autopreservação como uma experiência de prazer. De tal maneira que, na contramão da formação edípica, o caráter fascista não reprimia. As fantasias de destruição desses homens, por conseguinte, não eram, de modo algum, inconscientes, nem expressavam desejos recalcados. Elas exprimiam o pavor e a vontade de fusão, a ameaça latente de fragmentação e de dissolução do ego, a inabilidade em conviver com a vitalidade cambiante da realidade e o fracasso concreto da diferenciação que distinguia sua subjetividade dos objetos de desejo que vinham ao seu alcance ${ }^{90}$.

Theweleit tomou como protótipo de uma personalidade voltada ao fascismo os militantes dos Freikorps, homens cuja identidade fora forjada pelas academias e escolas militares ${ }^{91}$. Ali, seus corpos foram mecanizados e

89 THEWELEIT, Klaus. Male Fantasies: Volume 1: Women, Floods, Bodies, History. Tradução: Stephen Conway, Erica Carter, Chris Turner. Minneapolis: University of Minnesota Press, 2010, 88-9, 2046.

90 THEWELEIT, Klaus. Male Fantasies: Volume 1:Women, Floods, Bodies, History. Tradução: Stephen Conway, Erica Carter, Chris Turner. Minneapolis: University of Minnesota Press, 2010, 206-9 e THEWELEIT, Klaus. Male Fantasies: Volume 2: Psychoanalyzing the White Terror. Tradução: Stephen Conway, Erica Carter, Chris Turner. Minneapolis: University of Minnesota Press, 2010, XXI.

${ }^{91}$ Esses homens eram, por isso, o produto de um contexto histórico específico. Nas condições desse contexto, somente com muito esforço um jovem conseguiria resistir à insanidade que, mais tarde, o fascismo tornou socialmente aceitável. Pois, nas academias militares, a existência do cadete transcorria sob o signo da violência e da arbitrariedade. Sua ascensão às hierarquias superiores da caserna dependia da capacidade dos recém-chegados - ali, denominados Sacks 
aprenderam a funcionar sob comandos, performando harmonicamente nos conjuntos de linhas e colunas das tropas. Pernas e braços tornavam-se destros na marcha uniforme. O corpo mecanizado se integrava numa máquina de corpos, uma totalidade composta por cada soldado, organizada em formações geométricas conectadas umbilicalmente a uma central de energia, a uma ideia imantada num significante, "Alemanha". Em termos estéticos, o modo de produção fascista impunha a violação da matéria e sua compressão em blocos compactos, em formas rígidas, marchando em batidas regulares que buscavam incessantemente mais e mais totalidades uniformizadas. Essa grande máquina humana, em todas as suas engrenagens - colunas, linhas, corpos, braços, pernas - produzia uma forma estética orientada por uma motivação libidinal de confronto ao invés de fusão erótica. O desejo que então movia as peças não era o amor, mas a guerra ${ }^{92}$. Na batalha as potências do homem-máquina tornavam-se concretas. O combate promovia uma libertação destrutiva que falseava em explosão de gozo o persistente terror de dissolução do ego na massa. O que se extravasava era, então, o desejo anárquico de libertação da repressão. E isso promovia umasatisfação extraordinária, pois a cada confronto o objeto resistia e, portanto, solicitava mais esforços de destruição ${ }^{93}$.

No imaginário fascista, o androide, a criatura-máquina, ao contrário da metáfora liberal, correspondia, portanto, a uma figuração inédita do masculino,

\footnotetext{
("sacos") - de tolerarem os abusos e de compreenderem códigos de conduta para os quais não existia instrução alguma. Como num conto kafkiano, na sua condição de sacos, estavam sujeitos às mais brutais punições por transgressões que escapavam ao seu alcance. Pouco a pouco, seus corpos eram adestrados a aceitar as intervenções dolorosas com ansiedade, depois expectativa e, por fim, prazer. Eles eram extraviados do princípio do prazer e passavam a se regular por um "princípio de dor" que tornava agradável aquilo que lhes feria. Seu investimento emocional nunca mais se voltava ao deleite. Somente gozavam quando reconheciam os indícios de enrijecimento na periferia de seu corpo. Buscavam, por isso, endurecê-lo como uma armadura para acolher melhor o momento da fustigação. THEWELEIT, Klaus. Male Fantasies: Volume 2: Psychoanalyzing the White Terror. Tradução: Stephen Conway, Erica Carter, Chris Turner. Minneapolis: University of Minnesota Press, 2010, 143-53.

92 “Todos os esforços de estetização da política culminam em um ponto", observou, por conseguinte, Walter Benjamin. "Esse ponto é a guerra. Pois a guerra, e somente a guerra desfiava um propósito àqueles movimentos de grandíssima escala das massas". BENJAMIN, Walter. A obra de arte na época de sua reprodutibilidade técnica (segunda versão). Tradução: Francisco De Ambrosis Pinheiro Machado. Porto Alegre: Zouk, 2014, 117 e THEWELEIT, Klaus. Op. cit., 153-9, 200, 211.

93 THEWELEIT, Klaus. Op. cit., 201-4.
} 
não do feminino. Ao invés do mergulho no hedonismo, voltava-se para a destruição fálica. Ganhava os originais contornos das formações dos cadetes, com seus corpos fundidos e energizados pela fixação imaginária à Alemanha. Provia um sistema de engrenagens humanas acopladas em estruturas mais amplas, produzindo a totalidade de um Estado-máquina masculino partejado, à guisa de Goebbels, com romantismo e aço ${ }^{94}$.

Deleuze e Guattari atribuíram ao conceito de "máquina" uma qualidade mais do que metafórica. Vislumbraram nele um princípio funcional do desejo, um modo de operação do inconsciente cuja atividade essencial consiste na produção de conteúdos. O inconsciente opera como uma máquina de desejos que toma dos objetos as partes de que necessita para prosseguir numa ininterrupta ação produtiva. Essa atividade fabril constitui um modo de funcionamento que não persegue representações, mas se volta para modelar os contornos da realidade - não pretende impor significações aos conteúdos que produz, mas simplesmente seguir funcionando. Disso, concluíram Deleuze e Guattari, somente existe um tipo de produção inconsciente - a produção do real. Toda produção social é, portanto, uma produção desejante ${ }^{95}$. A partir do que Klaus Theweleit tomou as condições do fascismo alemão para estabelecer um modo próprio a ele de produção do real baseada na imagem do homem-máquina que oferecia ao ego uma última fronteira de resistência contra a inundação do desejo ${ }^{96}$.

A fantasia da inundação, registrou Theweleit numa variedade de casos, aparecia como uma representação constante no imaginário nazista e um meio simbólico de translação da realidade. O comunismo era, por isso, definido variavelmente como uma "inundação vermelha", uma "maré vermelha", uma "enchente bolchevique", uma "corrente de insurgência", um "grande dilúvio" ou um "furacão asiático" avançando contra o oeste civilizado. Do que concluiu que

\footnotetext{
94 THEWELEIT, Klaus. Op. cit. , 207, 210.

${ }^{95}$ DELEUZE, Gilles; GUATTARI, Félix. L'Anti-CEdipe: capitalismo et schizophrénie 1. Paris: Éditions de Minuit, 1972, 7-59 e THEWELEIT, Klaus. Male Fantasies: Volume 1: Women, Floods, Bodies, History. Tradução: Stephen Conway, Erica Carter, Chris Turner. Minneapolis: University of Minnesota Press, 2010, 212, 219.

96 THEWELEIT, Klaus. Op. cit., 220.
} 
a metáfora da inundação engendrava um estado claramente ambivalente de excitação. Ela era simultaneamente ameaçadora e atraente. A linguagem sugeria um uso simbólico para as águas. Pela imagem do fluxo violento, fixava o tema da destruição, um aprés nous le déluge que, na fantasia fascista, retinha o risco e o gozo da destruição total do ego ${ }^{97}$.
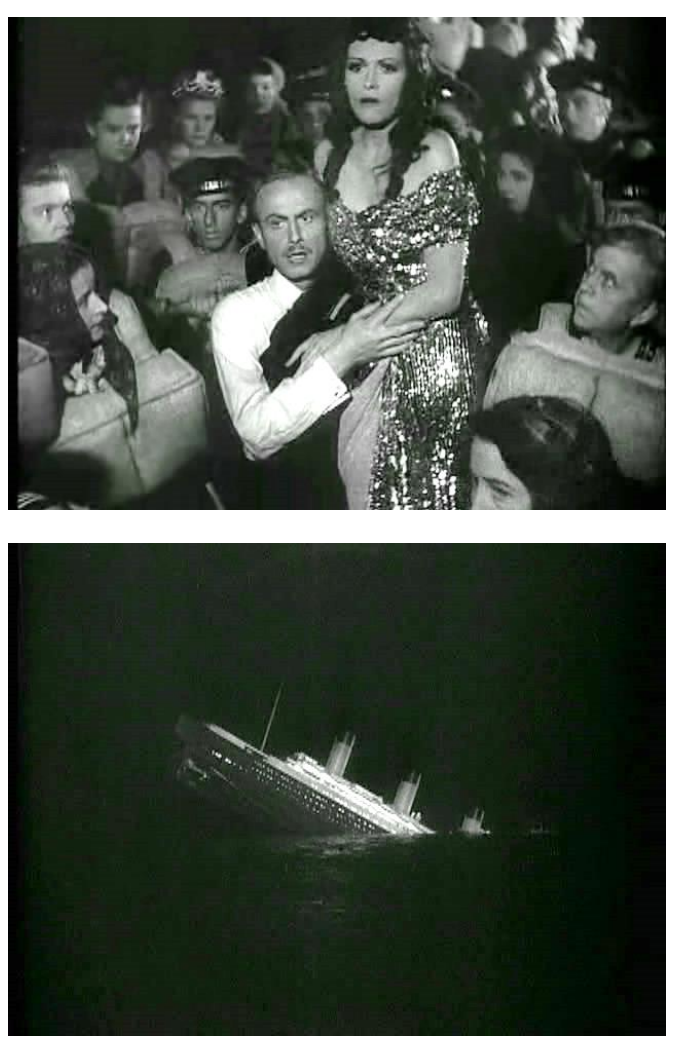

Figs. 4.9 e 4.10: Hans Nielsen e Sybille Schimtz.

Para uma personalidade fixada pela rigidez nas formações padronizadas das tropas, em suas linhas e colunas maciças e nas suas unidades impenetráveis, a imagem da inundação descontrolada parecia não apenas ameaçadora. Era ela a única potência radical apta a pulverizar as formas petrificadas pelas quais o caráter fascista se protegia das forças de dissolução da vida. A inundação, que tudo engolfa e deglute, produzia uma figuração da ruptura das barreiras internas, abrindo as comportas pelas quais o exterior se funde ao interior. O desejo de colisão, portanto, era tão extremo quanto o terror que ele prenunciava. Pois consistia num desejo de contato cuja realização se consumava pela morte, pela destruição do eu, pela aniquilação na solidão das águas - não na união de dois elementos, mas na extinção de um dentro de outro. Ao invés das correntes do amor era a penetração do corpo enrijecido no rio da morte que a imaginação fascista perseguia ${ }^{98}$.

As imagens líquidas, por conseguinte, formalizavam o pavor da dissolução do corpo masculino (e, por extensão, das fronteiras do seu self) no corpo feminino. Contra essa ameaça, o imaginário nazista interpunha o corpo encouraçado, armado, metalizado do soldado, protegido pelo revestimento simbólico de seu

\footnotetext{
97 THEWELEIT, Klaus. Op. cit., 229-30.

98 THEWELEIT, Klaus. Op. cit., 216, 218, 231-4.
} 
uniforme. O suave, o fluído, o languido e o feminino constituíam o negativo do corpo duro, organizado, esvaziado, metalizado, cuja apoteose não era mais o homem, mas a máquina da Wehrmacht conectada à Grande Alemanha. O que sugere que, em Titanic, a metáfora da inundação a qual invadia e engolia a carapaça metálica do transatlântico funcionava como uma libertadora fantasia fálica. Produzia uma variante pervertida da cena primitiva adequada ao prazer de um ego enrijecido, incapaz de experimentar o prazer sem nele entrever a possibilidade imanente da autodestruição ${ }^{99}$. Oferecia a uma seleta e privilegiada plateia de sobreviventes num bote salva-vidas um vislumbre do proibido, a visão do gozo da máquina rígida, fremente e ereta, penetrando em águas profundas, as quais, simbolicamente, remetiam a processos violentos de extermínio da ordem e submersão na barbárie. Pelo que o filme validava, com essa encenação alegórica da dissipação e extinção do poder na máquina total, a referência imediata da situação catastrófica da própria Alemanha nazista.

Por avançar rápido demais, essa máquina infalível falhou. Nenhuma imagem poderia se assentar melhor à Alemanha de 1943. Seguindo as convenções do disaster movie, somente uma categoria de personagens - os corajosos, os altruístas, os desprendidos e os abnegados - produziam melhores oportunidades de sobrevivência. Por conseguinte, o filme necessariamente investia no domínio da pulsão de morte para, assim, produzir uma fábula exemplar do verdadeiro heroísmo. Promovia uma fantasia na qual uma estrutura diferenciada retornava ao estado original de indiferenciação da matéria, em que tudo - distinções de classe, de gênero, de status civil ou militar - também desapareciam em uma massa informe. Essa fantasia cuidadosamente encenada no filme não podia remeter à memória de Weimar, que desapareceu da Alemanha sem desconstituir a composição socioeconômica a qual cindia a sociedade, mas, sim, à guerra total do Terceiro Reich. De modo que, onde parecia dramatizar apenas o declínio do liberalismo num acontecimento exemplar, Titanic também produziu

\footnotetext{
99 A Urszene, a cena primitiva, refere-se à precepção imaginária da criança a respeito da atividade sexual de seus pais, a qual a fantasia infantil, constatou Freud, usualmente não reconhece como um encontro amoroso, mas, ao contrário, como um ato de violência do pai contra a mãe. LAPLANCHE, Jean; PONTALIS, Jean-Bertrand. The Language of Psychoanalysis. Tradução: Donald Nicholson-Smith. Londres: Karnac Books, 1988, 335.
} 
reversivelmente a imagem de uma mutilação da Alemanha fascista, de uma fratura no seu grande corpo metálico. Antevia o momento em que, desfeitas todas as cisões sociais, a única diferença residual seria entre os bravos e os covardes numa variedade de exemplos de conduta com as quais o espectador poderia tomar como referência no momento em que tal desastre também se produzisse no seu próprio meio social.

\section{$\underline{\text { O Real }}$}

Havia, em Titanic, uma permanente tensão pela qual seu ambiente procurava intencionalmente imitar uma representação da Inglaterra para se referir à imagem cindida da Alemanha na sua dupla crise, a republicana e a fascista, formalizando-a numa alternância de gêneros, do melodrama ao filme catástrofe. Esse procedimento, longe de constituir um déficit na qualidade da propaganda, cumpria uma variedade de propósitos que se tornaram turvos pela distensão dos procedimentos de produção e pela estratégia de promoção do filme nos territórios ocupados antes que Goebbels tivesse a oportunidade de o lançar na Alemanha nazista (o que nunca veio de fato a acontecer).

Entre o momento inicial da concepção da obra e o contexto pretendido da sua recepção pública, a situação militar da Alemanha havia se deteriorado para além de qualquer remissão. Mas, em meados de 1942, quando o filme entrou em produção, os U-Boote, os submarinos alemães, dominavam o Atlântico. Já haviam torpedeado 6.250.000 toneladas de embarcações aliadas no Mediterrâneo e em torno da Inglaterra. Levaram 485 navios aliados a pique. O número de $U$-Boote em ação se erguera, por isso, de 22 em janeiro a 100 no final do ano. Mas, no início de 1943, os Aliados haviam aprimorado seus equipamentos de radar e de artilharia aérea, revertendo a vantagem naval nazista. A Batalha do Atlântico atingiu seu apogeu entre fevereiro e março desse ano: 50 embarcações alemãs foram destruídas em combate e, em maio, mais 37 U-Boote terminaram no fundo do mar. A rapidez da depleção e a qualidade dos equipamentos perdidos excediam largamente a capacidade de reposição da indústria bélica alemã. De 
modo que o almirante Karl Dönitz, comandante da Marinha, viu-se forçado a recuar a frota do Mar do Norte. E quando a lançou novamente ao combate, em setembro de 1943, amargou a perda de mais 64 submarinos, o que encerrou definitivamente a luta no Atlântico ${ }^{100}$. Ainda sob o impacto desses sombrios eventos, poucos dias depois, ocorria a première de Titanic em Praga com suas representações do caos, do desespero, dos afogamentos e da destruição de uma imensa embarcação. Pelo contexto da guerra nos mares, a ênfase na tragédia marítima revertera a mensagem positiva do filme a favor dos britânicos, esmaecendo os demais elementos publicitários da obra.

Havia, pelo filme afora, uma variedade de conteúdos que a todo tempo confundiam a localização metafórica do filme. Quando demandava do Capitão Smith que reduzisse a velocidade do navio para se precaver de um desastre, Petersen era acusado de "pessimismo malicioso" e de conspiração contra a excelência da engenharia naval britânica na sua rota para conquistar a Fita Azul. “Pessimismo malicioso" era, à época do filme, mais do que um insulto, mas um crime de traição largamente normatizado na jurisprudência nazista101. O que favorecia uma interpretação da ação no cenário de paranoia e conspiração da Alemanha fascista do que alhures, colocando Petersen numa indesejável situação de dissidente de uma ordem que se desmanchava ao seu redor.

Esse derretimento da ordem, contudo, podia também ser prontamente indexado não ao regime fascista, mas ao período weimariano. Pois, de 1925 a 1929, o Chanceler Heinrich Brüning proclamou a exceção mais de 150 vezes. Os

\footnotetext{
100 EVANS, Richard J. The Third Reich at War. Londres: Penguin Books, 2009, 481-2 e SHIRER, William L. The Rise and Fall of the Third Reich: a History of Nazi Germany. Nova York: Simon\&Schuster, 2011, 1007.

101 O Ato sobre práticas maliciosas (Verordnung zur Abwehr heimtüsckishe Diskreditierung der nationalen Regierung), decretado em março de 1933 determinava o banimento de comentários maliciosos contra o presente governo. A medida foi fortalecida pelo Ato de traição de 20 de dezembro de 1934 (a Heimtückegesetz) e a Lei contra ataques traiçoeiros ao Estado e ao Partido e pela proteção dos uniformes do Partido (Gesetz gegen heimütckische Angriffe auf Staat und Partei und zum Schutz der Parteinuniformen). As normas proscreviam críticas e comentários de contestação ao regime produzidas por pessoas "indesejáveis", às quais, pelo novo ordenamento, podiam ser removidas sob custódia preventiva do Estado - o que resulto na instituição, em uma fábrica de pólvoras na vila de Dachau, do primeiro campo de concentração voltado para o encarceramento por tempo indeterminado de pessoas por crimes de opinião. KERSHAW, Ian. Hitler. Tradução: Pedro Maia Soares. São Paulo: Companhia das Letras, 2010, 312.
} 
últimos anos da República, de fato, transcorreram em permanente estado de exceção. Quando Hitler tomou o poder, a excepcionalidade vigia há quase três anos, enquanto o Reichstag se desfazia em querelas ${ }^{102}$. Tão logo assumiu o comando, em 28 de fevereiro, Hitler baixou o Decreto de Proteção do Povo e do Estado que suspendeu os artigos da Constituição de Weimar referentes às liberdades pessoais. E porque o decreto nunca foi suspenso, do ponto de vista jurídico, o Terceiro Reich constituiu um permanente estado de exceção103.

Titanic podia então servir de referência à renovação da demanda pela situação de exceção que, tendo originado o Terceiro Reich em meio à crise republicana, tornara-se novamente necessária para revalidar o regime na sua própria crise de autoridade. Do que, então, o filme recuperava a memória das soluções radicais adotadas para superação dos impasses que fragmentaram a República, atualizando-as à situação crítica da Alemanha nazista. Pois desde 1942, a liderança do Terceiro Reich na frente doméstica claramente adentrara num período de dissolução. A administração civil e a burocracia estatal tornaram-se mais autônoma enquanto as intermitentes intervenções de Hitler pareciam erráticas, arbitrárias e contraditórias. O Führer se mostrava incapaz de administrar todos os assuntos internos do país, pelo que os departamentos do Estado passaram a fixar suas próprias regulamentações. Isso resultou numa crescente fragmentação do governo, o que aguçou as disputas entre as lideranças nazistas por mais espaço político ${ }^{104}$. Nesse contexto, Goebbels adotou a estratégia de reforçar a propaganda em torno da totalização da guerra pelo que, implicitamente, solicitava também uma radical centralização do Estado em torno do Führer. Obteve dele um decreto que permitia a realocação da maior parte da

\footnotetext{
102 Em 1930, Brüning, que perdera a maioria parlamentar, resistiu à renúncia dissolvendo a Câmara, o que doravante fez a Alemanha deixar de ser uma república parlamentar. Sob coligações partidárias flutuantes, os congressistas se reuniram esporadicamente até que, em 1932, Paul von Hindenburg, o último presidente da República, dissolveu definitivamente o Reichstag ele jamais foi restituído até o advento do nazismo. Hindenburg se colocou como um guardião da constituição e um protetor da democracia para exercer a derradeira rodada de ditadura constitucional que franqueou os meios de instalação do regime nazista e sua fixação definitiva no poder. AGAMBEN, Giorgio. State of Exception. Tradução: Kevin Attill. Chicago: University of Chicago Press, 2003, 15. 103 AGAMBEN, Giorgio. Op. cit., 2.

${ }^{104}$ EVANS, Richard J. Op. cit., 510-1.
} 
força de trabalho para a indústria bélica. Almejava lançar uma maciça campanha publicitária de mobilização militar, para, assim, reforçar o poder político de Hitler ${ }^{105}$. Titanic coincidia com esse projeto. Visto desse ângulo, o valor promocional de sua mensagem de coletivização do esforço para superação de uma situação extrema não poderia ter sido mais apropriado ao desígnio de retotalização da sociedade que o Ministro tão freneticamente perseguia.

Assim, o filme construía uma grande situação paranoica para justificar prospectivamente a necessidade de radicalização autoritária. O conteúdo conspiratório que tomava conta da cena parecia mais acentuado pelo desencontro de informações que se instaurava logo após a colisão com o iceberg. Até então, a propaganda britânica apresentara o Titanic como um navio "inafundável". Muitos sustentaram essa crença mesmo contra todas as evidências. Somente quando o Capitão Smith subia à ponte para declamar o canônico "salve-se quem puder", a realidade da catástrofe coincidia com um pronunciamento oficial. Nesse domínio, o filme se afigurava como um comentário crítico do poder mistificador de uma campanha publicitária encabeçada num eficiente slogan: God himself could not sink this ship.

Entre o momento do impacto e o da declaração oficial, a cena se abria para boatos, rumores, informações desencontradas e comunicados propositalmente falsos com vista à preservação da ordem. Tudo isso coincidia à perfeição com o passado de excepcionalidade política do período weimariano. Não obstante, em 1943, esse conteúdo extrapolou o propósito da propaganda para incidir negativamente sobre o regime que o comissionou como assunto publicitário ${ }^{106}$.

${ }^{105}$ LONGERICH, Peter. Joseph Goebbels. Tradução: Luiz A. de Araújo. Rio de Janeiro: Objetiva, 2014, 508-10.

106 O monopólio da informação pelo RMVP havia, até então, realizado eficientemente o desmantelamento da opinião pública, sugerindo uma atmosfera de conformidade ideológica e a ilusão da participação popular numa aprovação plebiscitária tácita do regime. Esse privilégio, contudo, começou a erodir em 1942. A princípio, a resistência popular à propaganda oficial restringia-se a comentários de descrença a respeito das elocuções governamentais e ao distanciamento voluntário dos canais de disseminação de conteúdos. Tornou-se mais aguda quando a correspondência dos soldados nos fronts passou a oferecer um panorama assombrosamente distinto daquilo que os meios de comunicação oficiais noticiavam. Entrementes, Goebbels reconheceu que, depois de inúmeras repetições, as mensagens políticas haviam se desgastado em expressões e estilos que o público passou a detestar. Os alemães já intuíam, nos sucessivos vácuos de silêncio dos porta-vozes do regime, a constrangedora lacuna 
Esse paradoxo, pelo que uma imagem doutrinária do Estado semianárquico liberal foi comutada na figura de um Estado semianárquico fascista era o problema que Titanic deveria deslindar. O filme fora orientado pela noção de que a anarquia liberal não era apenas mais perniciosa, mais letal e mais amoral do que a totalitária, mas, sobretudo, mais destrutiva, pois predestinava seus sujeitos à catástrofe. Esse argumento, válido em meados de 1940, quando a guerra parecia ser breve e vitoriosa, perdera a sustentação na realidade do contexto de sua exibição em 1943. Daí, os críticos levaram em conta apenas os aspectos da propaganda que caducaram para fixar no filme um retrato inadvertido da Alemanha nazista. Diagnosticaram a relação de equivalência com o desgoverno de uma liderança pomposa, mas fraca, que se evadia no momento de aflição social e não respondia pelos flagelos que ela mesma invocou. Reconheceram no navio um território para uma política de escapismo, de desinformação e de distração, retinindo como a banda que tocava ritmos vibrants para distrair os náufragos antes das águas geladas os alcançarem. O transatlântico era, assim, $\mathrm{O}$ espaço do boato, das perdas irreversíveis, do desespero sem liderança, do rompimento de pactos de confiança. Produzia a imagem terminal de um grande delírio, submergindo a vontade de potência na escuridão de um inferno gelado.

Paul Malone destacou a importância histórica de Titanic como um caso concreto dos meios de operação da propaganda nazista e de seu derradeiro fracasso. Considerou que, pela estatura mítica do acidente, o assunto superava largamente o âmbito estreito da invocação antibritânica para se voltar ao problema fundamental da luta pela sobrevivência nas condições mais adversas,

\footnotetext{
que antecedia justificativas para desastres terríveis na frente de guerra que o governo sempre se esmerava em edulcorar. Visando controlar o fluxo de informações, Goebbels passou a promover a disseminação programada de rumores por meios extraoficiais com a finalidade de preparar a população para posteriores notícias ominosas. Uma modalidade de contra-informação que, em breve, passou a operar desfavoravelmente ao regime. Essa Mundpropaganda ("propaganda de boca") escapou ao controle e começou a funcionar num timing próprio, disputando a primazia da fixação da realidade com os meios oficiais de informação. Daí em diante, a sociedade se viu exposta a boatos de todos os tipos, cuja proveniência e confiabilidade jamais podia ser determinada, produzindo expectativas infundadas (o advento de novas armas devastadoras como bombas e aeroplanos que reverteriam o desastre militar) e terrores injustificáveis (a súbita aliança da França com os Aliados, a prisão de Rommel pelos britânicos e a iminência de um ataque químico sobre Berlim, por exemplo). KALLIS, Aristotle A. Op. cit., 130-2, 137, 139 e KLEMPERER, Victor. Op. cit., 46.
} 
para as quais nenhuma figura de liderança poderia oferecer saídas ${ }^{107}$. Mas em Titanic havia algo mais do que a inadequação entre elementos subversivos contra um propósito doutrinário. O filme produziu um descompasso crucial não entre a essência da propaganda e a aparência que ela tomou, mas, ao contrário, entre o que o filme pretendia representar - a derrocada do idealismo liberal num desastre exemplar, minimizado pela atitude solidária preconizada pela doutrina nazista - e as implicações mais abrangentes implícitas na própria representação - um retrato alegórico de um sistema naufragando numa grande catástrofe pela gestão delirante e pela arrogância imprevidente de seus comandantes. Esse descompasso denunciava não apenas a profunda mudança de contexto entre o momento da produção e da recepção, mas o problemático funcionamento de uma doutrina (fascista e autoritária) nas malhas mais difusas da ideologia burguesa. Se, doutrinariamente, a mensagem do filme permanece inequívoca, ideologicamente ela podia flutuar, resistindo à fixação para oferecer múltiplas possibilidades de decodificação. Enquanto produto votado à cultura de massa, não servia unilateralmente a uma imagem doutrinária, mas às fantasias de seus espectadores. Era, antes de um dispositivo de retórica política, um articulador do desejo da sua audiência. Assim, podia se evadir da instrumentalização, escapando do domínio almejado pelos seus idealizadores para atravessar o campo fascista, o campo comunista e o campo liberal, permanecendo fiel apenas à própria fantasia de uma calamidade monumental que erradicava o sintoma tramático da civilização, selecionando os mais aptos à sobrevivência.

Nos termos da cultura de massa, o espaço que o filme ocupou provê uma evidência do quanto o meio social baliza suas próprias regras quando negocia seus desejos em troca de mercadorias artísticas. No contexto de 1943, do ponto de vista promocional, a imagem da máquina total descendo para o fundo do mar tornara-se, para além de qualquer dúvida, a mais indesejável possível. Titanic escapou ao desígnio de promoção da refundação autoritária e agora pronunciava, num imaginário paranoico, que o delírio de grandeza do Terceiro Reich terminou sepultado nas frias águas da inoperância administrativa - de 
onde, ademais, nunca mais se reabilitaria. A inadmissível mensagem fixada no clímax do filme era a destituição do Romantismo de aço pelo retorno do recalcado numa epígrafe baseada no Real, a qual os alemães, calejados por duas conflagrações internacionais, já conheciam de cor: "salve-se quem puder". Num país que a cada par de décadas trocava de regime e de sistema político e via seus sonhos de potência descambarem em pesadelos militares, devastações, calamidades e amputações no seu território, Titanic anunciava que o sonho de aniquilação no qual o nazismo tanto desejava submergir, finalmente o tragou. 


\section{Conclusão}

O canto do cisne da propaganda nazista foi também a mais prodigiosa realização do cinema alemão, Kolberg (Veit Harlan, 1945). E desde seu advento, críticos e historiadores têm sido unânimes em reconhecer, na massiva monumentalidade dessa superprodução, a imagem de uma estética terminal tão insubstancial quanto a situação do regime que a promoveu.

A obra falseava ostensivamente uma nota de rodapé da História contemporânea europeia, a resistência de uma pequena vila contra a investida de Napoleão após a queda de Jena e Austerlitz ${ }^{1}$. A ideia para um filme que dramatizasse a luta da pequena Kolberg (atualmente Kołobrzeg, situada na Polônia) surgiu no início da campanha militar alemã. Porém, somente foi enfaticamente reconsiderada em meados de 1943, tomando a forma de uma alegoria da causa nacional contra as mais extremas adversidades ${ }^{2}$. O incidente no qual a trama se baseava era de fato tão obscuro que a maioria das pessoas não sabiam que, na realidade, a cidade não resistiu, mas fora tomada pelo exército francês ${ }^{3}$. Kolberg foi o último produto cinematográfico que veio à cena como parte do programa de guerra total. O filme pertencia a uma categoria de promoção política particularmente valiosa a Goebbels, a propaganda positiva, baseada em conteúdos afirmativos das vantagens do povo alemão contra a ênfase em aspectos negativos da conjuntura da guerra. Daí, adquiriu uma significação especial aos olhos do Ministro, que redigiu a maior parte dos diálogos e promoveu as revisões na edição final da obra4.

Por isso, poucos filmes do Terceiro Reich explicitaram melhor os mecanismos de investimento estatal e de colaboração artística para um grande projeto publicitário - o qual seria, ademais, a última campanha de propaganda

\footnotetext{
${ }_{1}^{1}$ PETLEY, Julian. Capital and Culture: German Cinema 1933-45. Londres: British Film Institute (BFI), 1979, 114.

2 KALLIS, Aristotle A. Nazi Propaganda and the Second World War. Hampshire: Palmgrave Macmillan, 2005, 200 e TAYLOR, Richard. Film Propaganda: Soviet Russia and Nazi Germany. Londres, Nova York: I. B. Taurus, 2009, 196.

${ }^{3}$ EVANS, Richard J. The Third Reich at War: How the Nazis Led Germany from Conquest to Disaster. Nova York: Penguin Books, 2009, 573.

${ }^{4}$ KALLIS, Aristotle A. Op. cit., 131-2 e TAYLOR, Richard. Op. cit., 2009, 196.
} 
política nazista. Em todos os níveis - da seleção do tema, do ambiente de encenação e da equipe artística aos trabalhos de financiamento e distribuição - a realização perseguia o propósito de promover a mobilização e a resistência civil nos estertores do regime. Orçado em 8,5 milhões RM (oito vezes mais que as produções de qualidade da época), tornou-se o mais custoso filme de toda história da UFA. Numa época de escassez de recursos e de racionamentos generalizados, a produção dispendeu três mil metros de película em Agfacolor. O RMVP demandou a completa cooperação das demais instituições do Estado. Por isso, a Wehrmacht viu-se obrigada a dispensar 180 mil soldados e seis mil cavalos da frente soviética para servirem como figurantes nas cenas de batalha, justamente quando o exército vermelho avançava sobre a fronteira da Prússia. O filme contou com a imprescindível colaboração do diretor Veit Harlan, incumbido de colorir as visões de Goebbels com sua marca artística para sugestionar uma opinião pública que recobrara sua autonomia e resistia abertamente às campanhas do regime. Coincidindo com a mais devastadora ação de bombardeio sobre Berlim, a edição e a montagem enfrentaram imensas dificuldades. A cópia final demandou, sucessivos cortes e acréscimos para adequar a mensagem do filme à deterioração do contexto de recepção. As revisões de Goebbels, com vista a reduzir as impressionantes cenas de destruição em favor da representação do caráter heroico dos personagens, postergaram a conclusão dos trabalhos de novembro de 1944 para janeiro do ano seguinte. O esforço concertado das instâncias políticas e da equipe artística logrou, por fim, superar as imensas dificuldades do projeto para a efetivação de uma obra monumental ${ }^{5}$. Ainda assim, sua utilidade promocional beirou a nulidade.

Em 1945, a primeira cópia de Kolberg foi despachada de paraquedas sobre a fortaleza francesa de La Rochelle com a finalidade de fazer a première acontecer no último bastião ocupado da França, coincidindo com a celebração do $12^{\circ}$ aniversário de Hitler à frente da Chancelaria alemã. O lançamento ao público ocorreu em 30 de janeiro no cineteatro da UFA da Alexanderplatz. O Ministro imediatamente providenciou cópias para as regiões conflitadas da Alta Silésia,

${ }^{5}$ KALLIS, Aristotle A. Op. cit., 200-3. 
Frankfurt, Neisse e Könisberg. Disponibilizou o material a Göring, Himmler e Dönitz que, àquela altura, necessitavam do suporte de qualquer ficção para elevar o moral de seus homens. Porém, como os grandes cinemas da Alemanha jaziam em escombros, o filme circulou em pequenas salas para uma plateia cada vez mais exígua. Poucos dias depois, a verdadeira Kolberg começava a ser evacuada e, em março, já estava ocupada pelos russos ${ }^{6}$.

Kolberg promovia a mistura de melodrama romântico e filme histórico, sobre o que se apunha a legenda "baseado em fatos reais" para, sobre ela, fixar as falsificações conformes às litanias derradeiras de um regime agonizante. A obra perseguia o propósito de instruir o público de que um Volk unido no front doméstico pode derrotar até mesmo o mais poderoso inimigo. O povo, então, constituía a força universal decisiva para colocar a História adiante, superando a tibieza dos reis e dos príncipes ${ }^{7}$. No contexto das sucessivas crises militares que desagregaram o regime hitlerista, significativamente, Kolberg fixava a fonte da renovação nacionalista não mais no âmbito das forças armadas, mas na esfera civil. Na vila, precisamente no momento da máxima crise militar, os oficiais do exército tornaram-se recalcitrantes e indispostos à causa nacional. A defesa da cidade era, então, consignada à população liderada pelo Prefeito Nettelbeck (Heinrich George), o que fazia de um dissidente político, o novo protótipo de herói. Nettelbeck rejeitava a autoridade do Coronel Loucadou (Paul Wegener) e de seu staff de militares derrotistas e buscava amparo numa liderança autêntica, o jovem general Gneisenau (Horst Caspar) para organizar a resistência e enfrentar os invasores franceses ${ }^{8}$.

O filme tomava como mote os versos patrióticos de Theodor Körner, Der Volk steht auf, der Sturm bricht los ("o povo se ergue, a tempestade irrompe") - a mesma estrofe que Goebbels fez uso no seu discurso no Sportpalast em 1943. A legenda serviu de slogan à última campanha de conscrição, o Volksturm ("tempestade do povo"), que recrutou entre os enfermos, idosos e adolescentes as derradeiras milícias civis para engrossarem as fileiras residuais das frentes de

\footnotetext{
${ }^{6}$ EVANS, Richard J. Op. cit., 574, TAYLOR, Richard. Op. cit., 2009, 196, 206.

7 TAYLOR, Richard. Op. cit., 197-8.

8 PETLEY, Julian. Op. cit., 114.
} 
combate$^{9}$. Aplicado ao filme, o poema descrevia o ânimo marcial da população de Kolberg, votada à destruição por Napoleão, para assim inscrever uma história exemplar onde uma política de guerra total desdobrou-se prolificamente. Kolberg oferecia a delirante fantasia de como um povo desarmado e faminto, graças à excelência inata de sua estirpe, transformou-se num exército de cidadãos e se elevou à última coluna de defesa contra um inimigo invencível ${ }^{10}$.

Para promover tal mensagem, o filme inventariava um catálogo de figuras anacrônicas, que povoaram a publicidade do regime desde 1933, para pronunciarem um voto de esperança às aflições atuais. À frente da ação heroica, a produção oferecia uma trindade masculina. Primeiramente, Heinrich George, provavelmente o ator mais vinculado ao regime e à imagem da liderança autoritária hitlerista ${ }^{11}$. Em segundo lugar, Horst Caspar, identificado com heróis românticos e rebeldes desde Friedrich Schiler, der Triumph eines Genies ("Friedrich Schiller, o triunfo de um gênio", Herbert Maisch, 1940) representando o máximo líder marcial, Gneisenau. E, por fim, Gustav Diessl, no paradigmático papel do soldado enrijecido dentro de seu uniforme, casado com a guerra e lutando até a morte por uma causa perdida ${ }^{12}$.

Contrariamente, na retaguarda da covardia, dois exemplos negativos. De um lado, o velho Loucadou, encarnado por Paul Wegener, especialmente reconhecido pelos seus papéis de vilão em Hans Westmar. einer von vieler ("Hans Westmar, um entre muitos", Franz Wensler, 1933), Mein Leben für Irland ("Minha vida pela Irlanda", Max Kimmich, 1941) e Der große König (O grande rei, Veit Harlan, 1942)13. E, de outro, um músico afeminado (Kurt Meisel), corrompido

\footnotetext{
9 HOFFMANN, Hilmar. The Triumph of Propaganda Film and National Socialism, 1933-1945. Tradução: John A. Broadwin, V. R. Berghahn. Oxford: Birghahn Books, 1996, 230-1 e TAYLOR, Richard. Op. cit., 198.

${ }^{10}$ TAYLOR, Richard. Op. cit., 198, 200, 202.

${ }^{11}$ Heinrich George foi um dos primeiros astros a aderir incondicionalmente ao campo nazista. Emprestou seu talento a Hitlerjunge Quex (Mocidade heroica, Hans Steinhoff, 1933) e Kolberg, respectivamente o primeiro e o último filme de propaganda fascista. Entrementes, tornou-se uma presença constante nas mais prestigiosas produções do regime, o que fez dele o ator quintessencial do Terceiro Reich. KREIMEIER, Klaus. The Ufa Story: a History of Germany Greatest Film Coroporation, 1918-1945. Tradução: Robert Kimbler. Rita Kimbler. Berkeley, Los Angeles: University of California Press, 1999, 296.

12 KREIMEIER, Klaus. Op. cit., 295-6 e TAYLOR, Richard. Op. cit., 199, 201, 204.

13 TAYLOR, Richard. Op. cit., 199.
} 
pelo cosmopolitismo, que, agindo como colaborador, portava-se como um dos artistas psicóticos e hipersensíveis que rescendia, ainda em 1944, ao decadentismo weimariano ${ }^{14}$.

Entre um lado e outro, a trama interpunha, na frente civil, duas portentosas figuras femininas. Na corte real, a rainha da Prússia (Irene von Meyendorff) surgia numa única e marcante cena, envolta num mistificante halo de luz como uma diáfana fada para reverenciar Kolberg, a joia da Prússia e interceder a seu favor $^{15}$. E em Kolberg, o Reichswasserleiche, o cadáver d'água do Reich, a eterna mulher-menina, a náiade nórdica Kristina Söderbaum recebia sozinha os duros golpes da guerra ${ }^{16}$. Como em Die große Liebe e Titanic, sua personagem cumpria o papel da mulher envolvida romanticamente com um homem de armas, que renunciava aos seus anseios pessoais para também servir à causa militar. Agindo como um soldado, tornava-se desejável ao capitão que amava. Por isso, ela doava tudo de si para a batalha - o lar, o pai, os irmãos e o próprio homem amado - o que fazia dela, nas palavras de Nettelbeck, "uma mulher de verdade". De modo que, depois de inúmeras encarnações de suicidas, uma personagem de Söderbaum era a única coisa viva que remanescia no final do filme. A última vestal teutônica, na sua derradeira encarnação da virgem ariana, preservava-se da morte, porque nada mais havia na Alemanha pelo que morrer ${ }^{17}$.

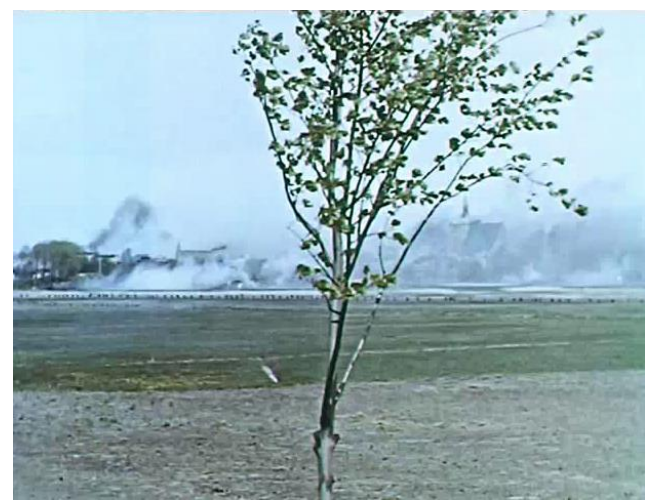

Fig. 5.1.

Com essa galeria de personagens, Kolberg recuava num imaginário devotado a celebrar a pulsão de morte. Exaltava a guerra como uma oportunidade de fortalecimento dos laços comunais. Convidava o povo a se desapegar de todas as suas posses, destruindo tudo de que dispunha - seus lares, suas terras e suas

\footnotetext{
14 TAYLOR, Richard. Op. cit., 199. 201.

${ }^{15}$ COURTADE, Francis; CADARS, Pierre. Histoire du cinema nazi. Paris: Eric Lostfeld, 1972, 228 e TAYLOR, Richard. Op. cit., 202.

16 PETLEY, Julian. Op. cit., 135.

17 KREIMEIER, Klaus. Op. cit., 297 e TAYLOR, Richard. Op. cit., 202, 205.
} 
propriedades - para legar uma terra arrasada ao inimigo. Nettelbeck, em diferentes momentos, incentivava que o povoado se enterrasse nas ruínas, pois isso era mais honroso do que a capitulação. Ao final do filme, o povo renascia, então, fantasmaticamente dos escombros aos acordes de um hino de ação de graças $^{18}$.

A visão cenográfica da cidade arruinada, com suas paredes calcinadas e os edifícios fumegantes produzia uma versão fictícia, colorida em Agfacolor, das imagens documentais em P\&B dos cinejornais, quando esses, anos atrás, celebravam a Europa devastada pela Wehrmacht. Era, pois, um contra-imaginário que Goebbels provia ao seu público: a evanescente memória da Alemanha pulverizada em chamas, renascendo como uma fênix na imagem simbólica de um verdejante broto de carvalho à frente da cidade destruída. Uma réplica cinematográfica da antiga cidade de Kolberg foi, por isso, reconstruída nos arredores de Berlim para ser queimada até o chão, promovendo um espetáculo tão grandioso quanto o incêndio de Atlanta em Gone with the Wind (E o vento levou, Victor Fleming, 1939).

Durante sua reclusão em Spandau, Albert Speer guardou na memória o deslumbramento de Hitler por um imaginário desse tipo, estritamente voltado à destruição. A visão do fogo, observou o arquiteto, afetava-o profundamente. $\mathrm{O}$ Führer assistia regularmente a filmes mostrando Londres em chamas e o incêndio de Varsóvia. Nos últimos anos da guerra, imaginava o quadro de uma Nova York aniquilada por um furacão de fogo. “Descreveu os arranha-céus tombando uns sobre os outros e as chamas gigantescas a iluminar o céu escuro", lembrou-se Speer ${ }^{19}$. Tudo isso, Kolberg provia. A cenografia crestada pelas chamas, dessubstanciada em fumaça, fazia então da ruína a derradeira teoria estética do Terceiro Reich ${ }^{20}$.

\footnotetext{
18 TAYLOR, Richard. Op. cit., 204, 237.

19 SPEER, Albert. Os diários secretos de Spandau. Tradução: Guilherme da Nóbrega Cesarino. Rio de Janeiro: Editora Arte Nova, 1995, 97.

20 Albert Speer, tentando imprimir numa figura arquitetônica ideal a admiração de Hitler pelos monumentos do passado greco-romano pronunciou uma "teoria do valor de ruína". A partir dela, os projetos de engenharia do Reich deveriam perseguir uma visão romântica da arquitetura, vislumbrada para durar milênios e, depois isso, decair graciosamente, produzindo belas ruínas. As colunas deveriam resistir para terminarem cobertas por heras e, assim, ilustrarem a
} 
Em termos promocionais, as ruínas de Kolberg provaram ser uma peça de propaganda supérflua e estéril. Quando ficou pronto para o lançamento, 237 cinemas de Berlim já estavam, eles próprios, em ruínas e fora de operação devido aos bombardeios. O colapso da rede ferroviária impediu que cópias do filme fossem distribuídas pelo país, de modo que poucas pessoas chegaram a prestigiar a produção ${ }^{21}$. Para esse público, pode-se ainda assim especular que, mesmo em condições menos extraordinárias, Kolberg teria despertado mais aversão à guerra, ao governo e ao nazismo do que simpatia e motivação. No crescente caos dos últimos meses do Reich, a influência de Hitler sobre as massas havia se dissipado e mesmo os nazistas ferrenhos criticavam espontaneamente o regime. $\mathrm{O}$ ressentimento da população contra as lideranças se tornara generalizado. Porque Hitler recusasse a rendição da Alemanha quando a guerra estava obviamente perdida, a indisposição popular escalou a níveis extremos. As pessoas começaram a remover as suásticas dos edifícios e depredavam emblemas nazistas nos locais públicos. Culpavam os líderes do Partido por persistirem sacrificando suas vidas inutilmente ${ }^{22}$. Contra o que, em 17 de abril, Goebbels pronunciou seu último discurso à frente do RMVP. Disse: “Cavalheiros, numa centena de anos no futuro, vocês estarão assistindo a um belo filme colorido dos dias terríveis que estamos atravessando. Vocês gostariam de representar que papel nesse filme? Aguentem firme agora, assim, numa centena de anos adiante, a audiência não irá vaiar e assobiar quando vocês aparecerem na tela" ${ }^{23}$.

A chave para a revelação de Kolberg e sua estética de ruínas não incidia, portanto, apenas nas plateias de seu contexto, mas almejava ao público do futuro, as audiências adventícias que poderiam apreciar o último gesto grandioso do cinema político fascista. Do que a vergonhosa derrota na guerra se comutaria num grande triunfo: a mensagem fascista persistiria para além do seu contexto, encarnada numa fantasia exemplar, que, no próximo século, serviria como o

persistência atemporal do Reich no rol dos grandes impérios clássicos europeus. SPEER, Albert. Inside the Third Rich: Memoirs. Tradução: Richard Winston, Clara Winston. Nova York: Simon \& Schuter, 56.

${ }^{21}$ EVANS, Richard J. Ibid.

22 EVANS, Richard J. Op. cit., 714-5.

${ }^{23}$ Menos de um mês depois, o Ministro se suicidou. TAYLOR, Richard. Op. cit., 207. 
testamento cinematográfico do Terceiro Reich.

Cumprindo seu papel testamentário, Kolberg, então, inventariava os doze anos de experimentos voltados à promoção publicitária do nazismo nas telas. Nettelbeck atualizava uma presença firmemente estabelecida pelos filmes de propaganda, o herói rebelde, em geral identificado às figuras históricas dos Geniusfilme investidas das feições de um proto-fascista. Como tal, visava apelar ao pequeno burguês com a fantasia da rebelião contra os aparatos da autoridade, mas dentro das margens seguras da doutrina ${ }^{24}$. Kolberg se voltava ao Geniusfilm também no episódio em que Napoleão reverenciava o túmulo de Frederico, o Grande, pelo que a obra prestava homenagem ao prolífico ciclo de filmes de propaganda que tomaram o rei da Prússia como modelo de liderança. Seu espírito, repousando em Potsdam, ainda velava pelo destino da nação como quando era vivo nos seus Friedericusfilme ${ }^{25}$

A realização provia personagens igualmente aptos a constelar num Kampfzeitfilm, em especial Gneisenau, a incontestável liderança fardada e estridente. $\mathrm{O}$ belo rosto de Horst Caspar sobreposto às bandeiras dos reinos germânicos no último plano da produção reproduzia o mesmo imaginário visual que encerrava Hans Westmar e SA Mann Brand ("Homem da SA Brand", Franz Seitz, 1933). Mediante o que o filme ressuscitava uma simbologia decadente, na qual a morte dos protagonistas era metaforizada pelas bandeiras, formalizando na matéria inerte a presença etérea dos mártires sacrificados em prol do nazismo ${ }^{26}$.

Kolberg, assim, provê um fascinante arranjo de temas e assuntos para uma historiografia voltada ao estudo da substância do poder, que toma o ponto de

\footnotetext{
24 PETLEY, Julian. Op. cit., 138-9.

${ }^{25}$ Para notas sobre o Geniusfilm, cf. pg. 52. Quanto a considerações a respeito do Friedericusfilme, cf nota 23 do Capítulo 1.

${ }^{26}$ Nos filmes do Kampfzeit, as bandeiras atualizavam a presença desses heróis numa forma carregada de simbolismo arcaico, provendo assim uma modalidade contemporânea de culto aos mortos. A imagem do espírito do herói se dissolvia e, em seu lugar, emergiam as triunfantes bandeiras do Reich. De modo que as bandeiras promoviam o prodígio da ressureição do fantasma e, assim, constituíam uma importante expressão da hagiografia totalitária. Esses emblemas da salvação engoliam todo espaço da tela. Forneciam a visão de uma identidade coletiva encarnada nas formas do tecido flutuante. Sob as bandeiras, os mortos marchavam ao lado dos vivos. Elas eram, por isso, um marcador da massificação e do indiferenciamento inscrito nos filmes como símbolo máximo da renovação da causa nacional. HOFFMANN, Hilmar. Op. cit., 24-5, 51-5.
} 
vista das agências ideológicas hegemônicas como o fundamento da análise. Oferece à linha materialista um prolífico material pelo qual se subsumem os sistemas doutrinários que, numa dada conjuntura, determinaram o destino histórico do continente europeu. Por isso, o filme produziu uma pletora de análises voltadas às mensagens emanadas de Goebbels e aos valores nazistas que ainda resistiam na agonia do regime. Dificilmente a essa obra canônica do cinema de propaganda fascista se aplicaria alguma análise pela linha psicanalítica de que se derivassem nele os produtos voltados às fantasias sociais de seus espectadores. Eram ali as fantasias do Ministro que tomaram a frente da cena para conjurar à posteridade o legado de um homem e de uma doutrina moribundos. Em Kolberg, então, inscrevia-se um exaltado elogio aos derrotados, aos arruinados, aos atemporais destroços da Alemanha e ao fracasso do sonho de potência. $O$ filme fazia tudo isso parecer seu inverso, uma vitória prospectiva, postergada para um eterno país do futuro. Pelo que a produção revalidava um actante prevalente nos filmes de propaganda nazista, o herói emasculado no momento de sua capitulação.

No cinema alemão, a fantasia do masculino em crise, antecedeu em muitos anos o regime fascista. Desde 1919, os filmes perscrutavam enredos e personagens que, direta ou indiretamente, remetiam ao trauma de guerra, à culpa pelos mortos e mutilados em batalha e à incapacidade de assimilação da derrota. Numa variedade de produções, os estados psíquicos de homens dilacerados por memórias terríveis ou psicologicamente perturbados pelo Zeitgeist da República de Weimar serviu para conformar aquela categoria de obras catalogadas com a etiqueta Expressionismo alemão ${ }^{27}$. E mais tarde, nas muitas variantes de Lola e Lulu, durante o período da Neue Sachlichkeit, a Nova Objetividade, a desestabilização da subjetividade masculina iria deslocar a responsabilidade pelos sentimentos de inadequação e impotência do homem à

\footnotetext{
${ }^{27}$ HALES, Barbara. Unsettling Nerves: Investigating War Trauma in Robert Reinert's Nerven (1919) in, ROGOWSKI, Christian (ed.). The Many Faces of Weimar Cinema: Rediscovering Germany's Filmic Legacy. Rochester, Nova York: Camden House, 2010, 31-3, 43-4, HANS, Anjeana. "These Hands Are Not My Hands": War Trauma and Masculinity in Crisis in Robert Wiene's Orlacs Hände (1924) in ROGOWSKI, Christian (ed.). Op. cit., 103-4 e OTTO, Elizabeth. Schaulust: Sexuality and Trauma in Conrad Veidt's Masculine Masquerades in ROGOWSKI, Christian (ed.). Op. cit., 144-6.
} 
"nova mulher" na sua encarnação contemporânea de femme fatale ${ }^{28}$. O macho castrado constituiu, assim, um actante permanente no cinema popular alemão. Ao invés de heroísmo, sua presença conjurava fantasias masoquistas de autoaniquilação, de rejeição ao passado traumático e de transferência dos impulsos associais à figura feminina. A derrota do masculino integrou um leitmotiv que, dessa maneira, transladou-se estavelmente de uma obra a outra, passando do momento republicano para a propaganda fascista onde sua presença ganhou o centro da encenação. A castração simbólica tornou-se, então, um protótipo idealizado de aderência dos personagens ao heroísmo melodramático fascista.

O cinema da época nazista ofereceu uma variedade de caracterizações do personagem que, vislumbrando uma ordem mais justa e harmônica - na qual se entreviam as noções do modernismo e do anticapitalismo reacionários da doutrina -, desafiava o status quo para terminar destruído, arruinado e solitário, mas remido pela grandeza de sua tragédia ${ }^{29}$. Ele protagonizou Hitlerjunge Quex (Mocidade Heroica, Hans Steinhoff, 1933), Der Kaiser von Kalifornien (O imperador da Califórnia, Luis Trenker, 1936), Wasser für Canitoga (“Água para Canitoga”, Herbert Selpin, 1939), Bismark (Wolfgang Liebeneiner, 1940), Carl Peters (Herbert Selpin, 1941), Friedemann Bach (Traugott Müller, 1941), Die Entlassung ("A exoneração", Wolfgang Liebeneiner, 1942) e Paracelsus (G. W. Pabst, 1943), para citar alguns exemplos. De maneira que, a essa coleção de derrotados se juntaram os gênios da História alemã, os aventureiros, os artistas, os cowboys do western nazista, os mártires do Kampfzeit e toda figura de vulto que, pelo seu destino trágico, validasse a violência contemporânea do regime.

Nas quatro obras investigadas nesse estudo, esse actante preencheu a cena para cumprir uma função crucial no desenlace de uma campanha política. Em Jud Süß, desvendava-se a solução para a Judenfrage, a questão judaica, pela resposta à mutilação que Oppenheimer impunha a Faber. No enforcamento do vilão, então, já se prefiguravam os contornos imaginários da destruição dos

\footnotetext{
28 ELSAESSER, Thomas. Weimar Cinema and After: Germany's Historical Imaginary. Londres, Nova York: Routledge, 200, 276-89.

${ }^{29}$ Para referências sobre o modernismo reacionário, cf. Capítulo 4, pg. 254-5. Para considerações acerca do anticapitalismo reacionário, ver Capítulo 4, pg. 226-7.
} 
judeus nos campos de concentração. A figura do alquebrado piloto Paul Wendlandt em Die große Liebe, por seu lado, solicitava a renovação do pacto social em torno da campanha militar e a comunhão dos fronts de guerra e doméstico para reversão da má fortuna da Alemanha no Leste. Um ano mais tarde, enquanto Goebbels conclamava a nação pela guerra total, o eterno Barão pronunciava seu voto de renúncia à imortalidade para se assujeitar à condição humana com uma enigmática invocação - "eu exijo tudo" - no que Ganzes ("tudo") coincidia com o adjetivo fundamental do nazismo, total ${ }^{30}$. Por fim, desconfortavelmente alojado entre os sobreviventes num bote salva-vidas, $\mathrm{o}$ Primeiro Oficial Petersen tornava-se o observador privilegiado da realização de sua terrível profecia de Cassandra. Confirmando seu vaticínio, testemunhava a perdição da máquina perfeita, contra o que somente triunfaram aqueles que cooperaram para a própria salvação.

Em todos esses personagens, inscreveu-se o signo da derrota, à qual o nazismo, com seu catálogo de valores pautados no Volk, na Heimat e no Bllut und Boden, dispunha-se a reabilitar, mesmo que ao custo de mais derrotas. Tomando proveito da iconografia cinematográfica da masculinidade interrompida, o propósito político dessas caracterizações era modular a disposição à renúncia, dispondo a virulência do regime como a resposta apropriada para a longeva crise de identidade do macho ariano.

Reconhecer essa incontestável finalidade política e as diferentes aplicações de tal dispositivo para atender circunstancialmente à agenda de propaganda do regime, contudo, não esgota a análise dessas obras. Pois elas chegaram ao seu público não como panfletos políticos, mas como filmes de entretenimento, pelo que reivindicavam a fixação do desejo em fantasias socialmente partilhadas. Daí que o cinema da época nazista não inventou nenhuma fórmula narrativa diferencial, nem tampouco alguma variedade estética discrepante ao cinema

\footnotetext{
30 Pois, na retórica nazista, total não representava um valor máximo, mas uma extrapolação do cálculo que excedia qualquer medida, do que Victor Klemperer enumerou algumas de suas aplicações - totaler Krieg ("guerra total"), totale Erziehungssituation ("ambiente de educação total"), totales Spiel ("jogo total") e, conspicuamente, totaler Staat ("Estado total"). KLEMPERER, Victor. LTI: a linguagem do Terceiro Reich. Tradução: Miriam Bettina Paulina Oelsner. Rio de Janeiro: Contraponto, 2009, 332-3.
} 
narrativo clássico. Para seduzir seus espectadores, esses e os demais filmes do período seguiam a tendência de tramar fantasias ao redor de personagens carismáticos, envolvidos em enredos intrigantes e emoldurados nas flexíveis formas genéricas que o público reconhecia e apreciava. Esses fundamentos asseguraram sua popularidade e preservaram o seu apelo mesmo depois da supressão de seu contexto sociopolítico.

$\mathrm{Na}$ transnacional comunidade imaginária constituída pelo meio virtual, esses filmes são, hoje, compartilhados clandestinamente em sites de vídeos, distribuídos em redes de streaming e resenhados em portais especializados. Integrando diferentes gerações de espectadores, essas páginas virtuais se sobrepõem, aparecendo e desaparecendo num constante devir. Perfis intermitentes na internet exclusivamente voltados ao cinema alemão dos anos 1930 e 1940 ou dedicados a algum dos seus artistas vêm reabilitando, assim, a popularidade de várias obras e performers. Dessa maneira, por exemplo, Paula Wessely e Marika Rökk, até há pouco completamente esquecidas pelo público, voltaram à cena numa nostálgica, ainda que seletiva rememoração de suas grandes performances. A húngara Rökk foi redescoberta no auge de sua forma em seus filmes realizados durante o Terceiro Reich, circulando integralmente na rede. Pelo que voltou a ser celebrada em suas vibrantes coreografias nos complexos números musicais de Gasparone (Gasparone, Georg Jacoby, 1937), Eine Nacht im Mai (“Uma noite em maio”, Georg Jacoby, 1938), Hallo Janine (Alô Janine!, Carl Boese, 1939), Kora Teri (“Kora Teri”, Georg Jacoby, 1940), Frauen sind doch bessere Diplomaten ("Mulheres são mesmo melhores diplomatas", Georg Jacoby, 1941) e Die Frau meiner Träume ("A mulher dos meus sonhos", Georg Jacoby, 1944). Já da austríaca Wessely, figuraram entre os favoritos dos internautas seus grandes papéis românticos, em alguns casos ao lado de seu marido Attila Hörbiger, com quem formou o casal dourado do cinema austríaco na época do Anschluß: Maskerade (Mascarada, Willi Forst, 1934), So endete eine Liebe (Assim acaba um grande amor, Karl Hartl, 1934), Die Julika (Julika, Géza von Bovary, 1936), Spiegel des Lebens ("Espelho da vida", Géza von Bovary, 1940) e Ein Leben lang (“Uma vida inteira”, Gustav Ucicky, 1940). Conspicuamente, da única e 
controversa participação do casal num filme de propaganda fascista, o infame Heimkehr ("Volta ao lar", Gustav Ucicky, 1941), uma peça difamatória contra os poloneses, apenas há pouco passaram a circular versões completas da obra ao invés de trechos seletivos. Pelo que os internautas puderam finalmente vislumbrar a atriz pronunciando o mais célebre discurso cinematográfico de exaltação à Heimat: "Imaginem como será, apenas imaginem, quando tudo ao nosso redor for alemão. Quando entrarmos numa loja, não escutaremos ídiche ou polonês, mas apenas alemão. E não apenas a aldeia, mas tudo nela será alemão. Nós estaremos no coração da Alemanha. Apenas imaginem, meus amigos. Por que não deveria ser desse modo? E, se não podemos viver uma vida alemã, pelo menos podemos morrer uma morte alemã. E mesmo mortos, seremos parte da Alemanha".

Para além da solicitação imaginária, de modo algum, esses filmes têm sido recepcionados acriticamente pelos seus espectadores adventícios, do que sua apreciação implicaria em alguma remissão automática dos horrores perpetrados pelo nazismo. Dentre os novos admiradores de Renate Müller no site youtube, por exemplo, invariavelmente uma parte das discussões se distancia da versatilidade dramática e vocal da atriz para se referirem também à sua mal situada posição no regime como uma das estrelas favoritas de Hitler e às circunstâncias de sua precoce morte ${ }^{31}$. O tema ressurge com tal incidência que sugere a persistência, ainda hoje, do problema da negociação entre o desejo e a doutrina nos caminhos subterrâneos pelos quais as obras culturais do Terceiro Reich chegam até os dias atuais.

Longe de procurarem esclarecimentos, os comentários apensos às visualizações dessas obras, usualmente redigidos em alemão, inglês e russo, indicam a massiva preferência pela sua apreciação estética do que pela exegese de sua função política nas décadas de 1930 e 1940. Assim, paulatinamente, figuras

\footnotetext{
${ }^{31}$ Apologistas coevos do fascismo atribuem a morte de Renate Müller, após a queda do alto de uma janela, à adição alcóolica e à depressão, o que a levou ao suicídio, enquanto seus demais apreciadores apontam as evidências do rompimento de suas relações com Goebbels e Hitler para preservar seu relacionamento com o editor judeu Karl Simon, do que lhe teria advindo uma visita letal da Gestapo.
} 
esquecidas ressurgem como favoritos de uma nostálgica rememoração, polarizando a atenção desse novo público. Em julho de 2017, um vídeo no youtube com Hans Albers performando Ein Wind weht von Süd und zieht mich hinaus auf See ("um vento sopra do Sul e me leva para além do mar"), os versos da canção romântica La Paloma em Große Freiheit Nr 7 (“Grande Liberdade, n 7", Helmut Käutner, 1944) contava com mais de 1,8 milhão de visualizações. Superava mesmo sua performance em Münchhausen, com 92 mil acessos em quatro anos de exposição. Dentre os mementos da época fascista, a atual popularidade de Albers somente tem sido menor do que a da estrela máxima do Terceiro Reich, Zarah Leander. Um clip com sua performance na canção-tema de Die große Liebe, Ich weiß es wird einmal ein Wunder geschehn ("Eu sei que uma vez um milagre vai acontecer") ultrapassou dois milhões de visualizações. A mesma cifra se aplica à sua interpretação da balada Nur nicht aus Liebe weinen ("Apenas não chore pelo amor") do filme Es war eine rauschende Ballnacht (Noite de baile, Carl Froelich, 1939). Sustentando sua reabilitação pública, Leander figura nos números musicais Kann denn Liebe sünde sein ("Pode o amor ser um pecado?") do filme Der Blaufuchs (A raposa azul, Viktor Tourjansky,1939) e Davon geht die Welt nicht unter ("Disso o mundo não vai acabar") também proveniente de Die große Liebe, respectivamente com 1,6 milhão e 1,5 milhão de acessos. Nesse último exemplo, um internauta comentou em alemão "isso não era a Alemanha", ao passo que outro, referindose a Ich weiß es wird einmal ein Wunder geschehn respondia a uma interpelação antifascista com outra questão: "Eu sou de extrema direita ou mesmo um verdadeiro nazista apenas por que gosto da música?".

Completamente desterradas do seu contexto político, com suas mensagens doutrinárias caducadas, do ponto de vista dos comentários disponibilizados pelos internautas, essas realizações permanecem galvanizadas pela tensão entre o desejo e a doutrina. Tais filmes e artistas seguem protagonizando uma candente querela, agora abrangendo um público mais amplo e difuso, distribuído em todas as partes do mundo, acerca da titularidade do entretenimento contra a prevalência do político. No domínio da cultura de massa, eles desafiam a ortodoxia das análises acadêmicas e, assim, servem a qualquer discurso 
ideológico. Pela excelência artística e técnica das produções, à audiência neofascista, esses filmes provêm um argumento de que a época nazista marcou um momento culminante de altivez cultural na Alemanha. Aos comentaristas antifascistas, as mesmas obras subsidiam abundantes indícios dos conteúdos atemporais da propaganda e de seus perversos efeitos retroativos (em especial a ilusória sugestão de que esses filmes coloridos e melódicos atestariam que o nazismo não constituiu, por trás da fachada glamorosa, um sistema extremo de terror estatal). Aqueles que rejeitam validar seu interesse estético pelas produções ao denominador político de sua conjuntura encontram nelas uma heterogênea mistura de entretenimento nostálgico ao qual se adiciona a mística dos objetos proscritos. Finalmente, para uma parcela de apreciadores que reencontraram essas realizações após longos anos de supressão, elas desenterraram memórias afetivas consteladas de significados simbólicos. Acerca da interpretação de La Paloma por Hans Albers, um internauta identificado como Leopold Ballek, 74 anos, comentou: “Conheço e amo essa música da minha infância. E ela sempre foi e ainda é a minha música favorita! E quando eu tiver que me despedir desse mundo, quero que essa música seja tocada. Para mim, ela simboliza tudo que pode haver de sentimento em uma longa vida: desejo, saudade distante, saudade do lar, partir e voltar, mas acima de tudo, amor".

Esses filmes servem hoje como antigamente para qualquer fixação do desejo numa fantasia retrospectiva. Para cada novo espectador proporcionam um mosaico de possibilidades e perspectivas de aproximação pelo que, agora, tornaram-se eles próprios o petit objet a da fantasia. Funcionam como a fração imaginária do passado o qual, do ponto de vista do sujeito que procura seu lugar na ordem simbólica, preenche o vazio da significação e provê sentido onde antes subsistia a hiância do real. Continuam, portanto, atuais, produzindo efeitos e afetos. São ainda parte de uma grande e problemática fantasia coletivamente partilhada.

Numa comédia ressuscitada pela internet, Die Feuerzangenbowle ("O ponche de pinças de fogo", Heinrich Spoerl, 1944), Heinz Rühmann, o mais perene ator alemão, interpretou o papel de Hans Pfeiffer, um grande escritor que regredia 
imaginariamente à adolescência. Essa farsa, uma das favoritas entre os alemães desde seu advento até os dias atuais, destituída de propaganda política e repleta de tiradas hilariantes, ganhou sua plateia em janeiro de 1944. Coincidiu, portanto, com a mais devastadora onda de bombardeios aliados sobre as grandes cidades do país, o que enterrou qualquer vestígio residual de otimismo com a guerra no front doméstico ${ }^{32}$. Nenhum momento poderia ser mais oportuno para uma comédia tresloucada com o espirituoso Rühmann.

Vestido em calção e boné, Pfeiffer transformava sua escola num tropel, flertava com a filha do diretor e zombava da autoridade dos professores, tudo isso para prestar uma homenagem "ao desejo que nos impele, com o qual devemos nos contentar". Num desfecho emblemático, o tom da comédia desaparecia para dar lugar a um raro momento melodramático na carreira do ator, quando Rühmann, num imenso close-up, voltava-se à câmera e interpelava diretamente o espectador. "Eu confesso publicamente que menti sobre toda essa história, de A a Z", dizia melancólica e resignadamente. “Eu inventei até mesmo a mim próprio".

Desse inusitado final, subsistem variadas possibilidades de aproximação analítica. Nele, de um lado, podiam-se antever os preâmbulos dos processos de denegação com os quais os simpatizantes, os complacentes e os conformistas se juntariam na rejeição à culpa pelo papel passivo que prestaram à legitimação da ordem fascista. Por outro lado, nessa prontidão em admitir a disposição para a mentira, o filme, então, parecia estabelecer um acerto de contas não com o futuro, mas com o presente, no que, então, sugeria o enfraquecimento dos controles doutrinários pelas agências ideológicas. Daí, a realidade da grande mentira podia ser significada tão ostensivamente. Finalmente, além de tudo isso, no diálogo cifrado entre o grande astro e seu meta-espectador, subjazia a premissa de que ninguém enganou ninguém - ambos faziam parte de uma mentira coletivamente partilhada. O que, portanto, implicava a cena não no âmbito da psicologia de massa ou da disputa política material, mas no domínio semântico e

\footnotetext{
32 SHIRER, William L. The Rise and Fall of the Third Reich: a History of Nazi Germany. Nova York: Simon \& Schuster, 2011, 1008-10.
} 
metalinguístico. Pois, ali, Pfeiffer desmascarava a ilusão do aparato cinematográfico. Discriminava o mecanismo pelo qual uma história delirante tomava forma, ganhava vida, produzia sensações e retornava inocuamente aos desvãos da imaginação criativa, onde a ilusão seguia produzindo o efeito de prazer. O filme, daí, explicava a si mesmo como um ato volitivo da fantasia, voltado à finalidade de satisfazer "o desejo que nos impele". Die Feuerzangenbowle, dessa maneira, assenta-se respectivamente à leitura psicanalítica, à análise materialista e à exegese semiótica.

Qualquer que seja a linha de interpretação, o efeito de descolamento promovido por esse desfecho, do que a crítica pode derivar uma leitura alinhada ao seu método, depende de sua peculiar qualidade extra-cênica. O close-up fechava o quadro no rosto de Rühmann encanecido pela maquiagem, o que fazia todos os demais elementos cênicos desaparecerem. Remanescia apenas o tête-àtête entre o astro e o público situado num espaço indefinido, fora da cena, obsceno. No que o filme produzia, então, uma forma perfeitamente assentada ao seu contexto psico-ideológico.

O fascismo, observou Žižek, credenciou-se junto às massas precisamente pela qualidade obscena de sua retórica, que formalizava a solicitação à renúncia como um fim em si mesmo. Contra o decadentismo liberal e a degeneração marxista, o sacrifício não deveria comportar nenhum outro objetivo do que preencher a forma oca do sacrifício enquanto tal. Essa obscenidade não procurava o significado sacrificial numa cena, mas no gesto vazio da encenação. O matiz obsceno, que os críticos liberais e marxistas denunciavam como a principal debilidade do fascismo, era, ao contrário, a motivação fundamental do seu apelo. "É, por isso, evidente porque o fascismo era tão aterrorizado pela psicanálise”, observou Zizek: “a psicanálise nos habilita a localizar o gozo obsceno em funcionamento no ato do sacrifício formal" 33 .

Esse "gozo obsceno" acompanhou o cinema produzido durante o Terceiro Reich, desde seus primeiros momentos, quando as multidões clamavam por seu Führer porque desejavam veementemente sua própria servidão. As massas, 
recordaram Deleuze e Guattari, jamais foram ludibriadas pelo fascismo. Elas o esperavam numa dada circunstância em que o campo social estabeleceu uma conexão eficiente com o desejo ${ }^{34}$. Essa conexão, não obstante, persistiu precariamente e, uma vez desfeita, nunca mais se reabilitou. $\mathrm{O}$ nazismo jamais subsistiu como uma entidade constante e homogênea. Seu apelo flutuou, alcançou altitudes elevadas quando fixou compromissos insustentáveis com seus interlocutores e, pouco a pouco, despencou das alturas, mergulhando sua doutrina em descrédito. Essa trajetória penetrou nos filmes que, como um inventário da memória coletiva, preservou, nas formas flutuantes de suas fantasias, os complexos embates ideológicos deflagrados entre o desejo que resistia à doutrina e uma doutrina voltada à erradicação do desejo. Todas as obras analisadas nesse estudo atestam a envergadura e a extensão desses embates que ainda não cessaram de ocorrer.

Na súbita ressurgência dessa cinematografia pelo meio virtual, as mesmas questões permanecem assombrando seu público. Pela controversa proveniência desse cinema, seus novos espectadores necessariamente assumem uma linha ideológica pela qual se habilitam a emoldurar o quadro que melhor convém à sua apreciação. A cada novo filme subterraneamente disponibilizado nas redes de compartilhamento, então, abre-se uma oportunidade de perscrutar os caminhos pelos quais as disputas entre o desejo e a doutrina persistem. E, por extensão, a durabilidade do apelo desse cinema obriga à reflexão dos sistemas ideológicos profundos que, atravessando as conjunturas fascista e liberal, permitem, ainda hoje, a decodificação de suas fantasias num registro atraente e intrigante. Discutir o papel ideológico-doutrinário dos produtos artísticos oriundos da Alemanha nazista apenas do ponto de vista de suas mensagens políticas , portanto, apaga do campo analítico o crucial papel da indústria cultural e de seus agentes produtores, artistas e consumidores - na modulação do desejo pela organização disciplinada das fantasias sociais em formatos que vêm funcionando estavelmente dentro dos mesmos padrões, em qualquer contexto, nazifascista ou

\footnotetext{
${ }^{34}$ DELEUZE, Gilles; GUATTARI, Felix. L'Anti-CEdipe: capitalismo et schizophrénie 1. Paris: Éditions de Minuit, 1972, 46-8.
} 
democrático-liberal - e em qualquer época, no passado e no presente. Daí que os filmes do Terceiro Reich, mesmo carregando consigo as emanações do opróbrio e das abominações do nazismo, ainda se ofereçam ao seu público contemporâneo como objetos paradoxais, a um só tempo enigmáticos e atuais, mas também ambíguos, problemáticos e controversos. Pelo que persistentemente seguem resistindo às leituras unívocas nas quais as complexidades de suas formas desaparecem sob o véu da maléfica doutrina que labutava para inocular suas monolíticas mistificações nas resilientes e fluidas malhas da fantasia fílmica. 


\section{Filmografia}

Os filmes estão referidos pelos seus títulos originais em italic. Entre os parênteses foram discriminados seus títulos de lançamento no Brasil em italic, quando esse foi o caso, ou, a tradução aproximada dos títulos entre aspas, quando as obras não foram exportadas. Entre parênteses estão igualmente fixados o nome do diretor da produção e a data de seu lançamento, referindo-se à apresentação inaugural da obra, seja na Alemanha, Áustria ou nos territórios ocupados pelos alemães durante a Segunda Guerra Mundial.

Hitlerjunge Quex (Mocidade Heroica, Hans Steinhoff, 1933)

Hans Westmar: einer von Vielen ("Hans Westmar: um entre muitos”, Franz Wenzler, 1933)

SA Mann Brand ("Homem da SA Brand", Franz Seitz, 1933)

Der Tunnel ("O túnel”, Curtis Bernhardt, 1933)

Gold (Ouro, Karl Hartl, 1934)

Maskerade (Mascarada, Willi Forst, 1934)

So endete eine Liebe (Assim acaba um grande amor, Karl Hartl, 1934)

Abscheidswalzer (A valsa do adeus, Géza von Bolváry, 1934)

Der alte und der junge König (Alma mascarada, Hans Steinhoff,1935)

Das Mädchen Johanna (Santa Joanna D'Arc, Gustav Ucicky, 1935)

Ein idealer Gatte (“Um marido ideal”, Herbert Selpin, 1935)

Fährmann Maria (“Balseiro Maria”, Franz Wysbar, 1936)

Friedericus, der alte Fritz ("Frederico, o velho Fritz”, Johannes Meyer, 1936)

Der verlorene Sohn (O filho pródigo, Luis Trenker, 1935)

Der Kaiser von Kalifornien (O imperador da Califórnia, Luis Trenker, 1936)

Die Julika (Julika, Géza von Bovary, 1936)

Verräter ("Traidor", Karl Riter, 1936)

Gasparone (Gasparone, Georg Jacoby, 1937)

La Habanera (La Habanera, Detlef Sierk, 1937)

Der Herrscher (Crepúsculo, 1937) 
Der Mann, der Sherlock Holmes war (Sherlock Holmes, Karl Hartl, 1937)

Premiere (Première, Géza von Bolváry, 1937)

Zu neuen Ufern (Recomeça a vida, Detlef Sierk, 1937)

Capriccio (Caprichos, Karl Ritter, 1938)

Jugend (Juventude Ardente, 1938)

Eine Nacht in Mai ("Uma noite em maio", Georg Jacoby, 1938)

Heimat (Pecado de amor, Carl Froelich, 1938)

Der Tanz auf dem Vulkan ("Dança sobre o vulcão", Hans Steinhoff, 1938)

Verwehte Spuren (Angústia em Paris, 1938)

Die vier Gesellen ("As quatro companheiras", Carl Froelich, 1938)

Der Blaufuchs (A raposa azul, Viktor Tourjansky,1939)

Es war eine rauschende Ballnacht (Noite de baile, Carl Froelich, 1939)

Frau am Steuer ("Mulher no comando", Paul Marin, 1939)

Hallo Janine (Alô Janine!, Carl Boese, 1939)

Hotel Sacher (Hotel Sacher, Erich Engel, 1939)

Leinen aus Irland ("Linho da Irlanda", Heinz Helbig, 1939)

Das Lied der Wüste ("A canção do deserto", Paul Marin, 1939)

Robert Koch, der Bekämpfer des Todes (Robert Koch, 1939)

Robert und Bertran (“Robert e Bertran”, Hans Heinz Zerlett, 1939)

Das unsterbliche Herz ("O coração imortal”, Veit Harlan, 1939)

Wasser für Canitoga (“Água para Canitoga”, Herbert Selpin, 1939)

Bismark (Wolfgang Liebeneiner, 1940)

Ein Leben lang (“Uma vida inteira”, Gustav Ucicky, 1940)

Der ewige Jude (“O judeu eterno”, Fritz Hippler, 1940)

Feldzug in Polen ("Campanha na Polônia", Fritz Hippler, 1940)

Die Feuertaufe ("O batismo de fogo", Hans Bertram, 1940)

Friedrich Schiller, der Triumph eines Genies ("Friedrich Schiller, o triunfo de um gênio", Herbert Maisch, 1940)

Der Fuchs von Glenarvon (Max Kimmich, 1940)

Das Herz der Königin (“O coração da rainha”, Carl Froelich, 1940)

Jud SüB (“Judeu Süss, Veit Harlan, 1940) 
Kora Teri (“Kora Teri”, Georg Jacoby, 1940)

Die Rothschilds Aktien auf Waterloo ("Os títulos dos Rothschilds em Waterloo",

Erich Waschneck, 1940)

Trenck, der Pandur (“Trenck, o Pandur”, Herbert Selpin, 1940)

Ein Mann auf Abwegen (“Um homem em desatino", Herbert Selpin, 1940)

Spiegel des Lebens ("Espelho da vida”, Géza von Bováry, 1940)

Wunschkonzert ("Pedido de concerto", Eduard von Borsody, 1940)

... reitet für Deutschland (“... cavalga pela Alemanha”, Arthur-Maria Rabenalt, 1941)

Annelie (Josef von Baky, 1941)

Aufwiedersehen Franziska (Adeus, Francisca!, Helmut Käutner, 1941)

Carl Peters (Herbert Selpin, 1941)

Ewiger Rembrandt ("Eterno Rembrandt", Hans Steinhoff, 1941)

Frauen sind doch bessere Diplomaten ("Mulheres são mesmo melhores diplomatas", Georg Jacoby, 1941)

Friedemann Bach (Traugott Müller, 1941)

Heimkehr ("Volta ao lar", Gustav Ucicky, 1941)

Komödianten ("Comediantes", Georg Wilhelm Pabst, 1941)

Mein Leben für Irland ("Minha vida pela Irlanda", Max Kimmich, 1941)

Ohm Krüger (“Tio Krüger”, Hans Steinhoff, 1941)

Sieg in Western (“Vitória no Oeste”, Fritz Brunsch, Svend Noldan, 1941)

Stukas ("Bombardeiros”, Karl Ritter, 1941)

Über alles in der Welt ("Acima de tudo no mundo", Karl Ritter, 1941)

U-Boote westwärts ("Submarinos rumo ao Oeste", Günther Rittau, 1941)

Andreas Schüller (Herbert Maisch, 1942)

Diesel (Gehard Lamprecht, 1942)

Die Entlassung ("A exoneração”, Wolfgang Liebeneiner, 1942)

Der große König (O grande rei, Veit Harlan, 1942)

Geheimakte WB I (“Dossiê secreto WB I”, Herbert Selpin, 1942)

Die goldene Stadt (Cidade da ilusão, Veit Harlan, 1942)

Die große Liebe (“O grande amor”, Rolf Hansen, 1942) 
Wen die Götter lieben (“Quem os deuses amam”, Karl Hartl, 1942)

Besatzung Dora ("Tripulação Dora”, Karl Ritter, 1943)

Damals ("Outrora", Rolf Hansen, 1943)

Immensee ("Lago das abelhas", Veit Harlan, 1943)

Münchhausen (Josef von Baky, 1943)

Paracelsus (Georg Wilhelm Pabst, 1943)

Titanic (Herbert Selpin/Werner Klingler, 1943)

Wien, 1910 (“Viena, 1910”, E. W. Emo, 1943)

Die Feuerzangenbowle ("O ponche de pinças de fogo", Heinrich Spoerl, 1944)

Die Frau meiner Träume ("A mulher dos meus sonhos", Georg Jacoby, 1944)

Große Freiheit Nr 7 (“Grande Liberdade, n 7”, Helmut Käutner, 1944)

Opfergang ("Sacrificio", Veit Harlan, 1944)

Romanze in Moll (“Romance em bemol”, Helmut Käutner, 1944)

Kolberg (Veit Harlan, 1945)

Unter dem Brücken (“Sob as pontes”, Helmut Käutner, 1945)

\section{Créditos de imagens}

Capítulo 1: fotogramas do filme Jud Süß (direção: Veit Harlan; direção de fotografia: Bruno Mondi/ Terra Filmkunst, 1940).

Capítulo 2: fotogramas do filme Die große Liebe (direção: Rolf Hansen; direção de fotografia: Hans Theyer/UFA, 1942).

Capítulo 3: fotogramas do filme Münchhausen (direção: Josef von Baky; direção de fotografia: Konstantin Irmen-Tschet e Werner Krien/UFA, 1943).

Capítulo 4: fotogramas do filme Titanic (direção: Herbert Selpin/Werner Klingler; direção de fotografia: Friedl Behn-Grund/Tobis Filmkunst, 1943).

Conclusão: fotograma do filme Kolberg (direção: Veit Harlan: direção de fotografia: Bruno Mondi/UFA, 1945) 


\section{Referências bibliográficas}

ADORNO, Theodor W. Ensaios sobre psicologia social e psicanálise. Tradução: Verlaine Freitas. São Paulo: Editora Unesp, 2015.

Introdução à sociologia da música. Tradução: Fernando R. de Moraes Barros.

São Paulo: Editora Unesp, 2011.

Introdução à sociologia. Tradução: Wolfgang Leo Maar. São Paulo: Editora

Unesp, 2008.

Minima Moralia: reflexões a partir da vida lesada. Tradução: Gabriel Cohn.

Rio de Janeiro: Beco do Azougue, 2008.

Teoria Estética. Tradução: Arthur Mourão. Lisboa: Edições 70, 2013.

ADORNO, Theodor W.; HORKHEIMER, Max. Dialética do Esclarecimento. Tradução: Guido Antonio de Almeida. Rio de Janeiro: Zahar, 1985.

AGAMBEM, Giorgio. Profanações. Tradução: Selvino J. Assmann. São Paulo: Boitempo, 2007.

Homo Sacer: poder soberano e a vida nua. Tradução: Henrique Burigo. Belo Horizonte: Editora UFMG, 2007.

Meios sem fim: notas sobre a política. Tradução: Davi Pessoa. Belo Horizonte: Autêntica Editora, 2015.

Press, 2003.

State of Exception. Tradução: Kevin Attill. Chicago: University of Chicago

ALAIN-MILLER, Jacques, Percurso de Lacan: uma introdução. Tradução: Ari Roitman. Rio de Janeiro: Zahar, 1997.

ARENDT, Hannah. Compreender: formação, exílio e totalitarismo (ensaios) 1930-54. Tradução: Denise Bottman. São Paulo: Companhia das Letras. Belo Horizonte: Editora UFMG, 2008.

Guilty and Universal Responsibility in BAEHR, Peter (ed.). The Portable Hannah Arendt. Londres: Penguin, 2000.

The Origins of Totalitarism. Nova York: Harcourt, 1997.

ASCHEID, Antje. Hitler's Heroines: Stardom and Womanhood in Nazi Germany. Filadélfia: Temple University Press, 2003.

AUMONT, Jacques. A imagem. Tradução: Estela dos Santos Abreu, Cláudio Cesar Santoro. Campinas, São Paulo: Papirus, 2012.

L'œil interminable: Cinéma et peinture. Paris: Éditions Séguier, 1995.

AUMONT, Jacques; MARIE, Michel. A análise do filme. Tradução: Marcelo Felix. Lisboa: Edições Texto\&Grafia, 2013.

BALIBAR, Etienne; WALLERSTEIN, Immanuel. Race, nation, classe: les identités ambiguës. Paris: Éditions La Découverte, 1990.

BATAILLE, Georges. A literatura e o mal. Tradução: Fernando Scheibe. Belo Horizonte: Autêntica Editora, 2015.

BENJAMIN, Walter. A obra de arte na época de sua reprodutibilidade técnica (segunda versão). Tradução: Francisco De Ambrosis Pinheiro Machado. Porto Alegre: Zouk, 2014.

BERGFELDER, Tim: STREET, Sarah (ed.). The Titanic in Myth and Memory: 
Representations in Visual and Literary Culture. Nova York: I. B. Taurus, 2004.

BRECHT, Bertolt. Diario de trabajo I 1938/1941. Tradução: Hélida Mendilaharzu de Machain. Buenos Aires: Ediciones Nueva Visión, 1977.

Terror e miséria do Terceiro Reich. Tradução: Christine Röhrig, Marcos

Renaux, in BRECHT, Bertolt. Teatro completo em 12 volumes, V. São Paulo: Paz e Terra, 1991.

BROOKS, Louise. Lulu in Hollywood: Expanded Edition. Minneapolis. University of Minnesota Press, 2000.

BROOKS, Peter. The Melodramatic Imagination: Balzac, Henry James, Melodrama, and the Mode of Excess. New Haven e Londres: Yale University Press, 1995.

CAILLOIS, Roger. L'home et le sacré. Paris: Gallimard, 2013.

CÂNDIDO, Antonio, ROSENFELD, Anatol, PRADO, Décio de Almeida, GOMES, Paulo Emílio Salles. A personagem de ficção. São Paulo: Perspectiva, 2011.

CANETTI, Elias. Crowds and Power. Tradução: Carol Stewart. Nova York: Farrar, Straus and Giroux, 1984.

Uma luz em meu ouvido: história de uma vida 1921-1931. Tradução: Kurt Jahn. São Paulo: Companhia das Letras, 2010.

CARTER, Erica. Dietrich's Ghosts: the Sublime and the Beautiful in the Third Reich Film. Londres: British Film Institute (BFI), 2011.

CLINEFELTER, Joan. Artists for the Third Reich: Culture and Race from Weimar to Nazi Germany. Oxford, Nova York: Berg, 2005.

CORBIN, Jean-JacqueS Courtine; VIGARELLO, George. História da Virilidade 3: a Virilidade em crise - séculos XX-XXI. Tradução: Noéli Correia de Mello Sobrinho, Thiago de Abreu e Lima Florênciao. Petrópolis e Rio de Janeiro: Vozes, 2013.

COURTADE, Francis; CADAR, Pierre. Histoire du Cinéma Nazi. Paris: Eric Losfield, 1972.

DAVIDSON, H. R. Ellis. Gods and Myths of Northern Europe. Londres: Penguin Books, 1990.

DELEUZE, Gilles; GUATTARI, Felix. L'Anti-CEdipe: capitalismo et schizophrénie 1. Paris: Éditions de Minuit, 1972.

DOANE, Mary Ann. The Desire to Desire: the Woman's Film of the 1940's. Blooming: Indiana University Press, 1987.

ELIADE, Mircea. Mito e realidade. Tradução: Pola Civelli. São Paulo: Perspectiva, 1991.

ELIAS, Norbert. Os alemães: a luta pelo poder e a evolução do habitus nos séculos XIX e XX.

Tradução: Álvaro Cabral. Rio de Janeiro: Zahar Editora, 1997.

ELLIOT, J. H. A Europa dividida: 1559-1598. Tradução: Conceição Jardim e Eduardo Nogueira. Lisboa: Editorial Presença, 1985.

ELSAESSER, Thomas (ed.). A Second Life: German Cinema's First Decades. Amsterdam, Amsterdam University Press, 1996.

Weimar Cinema and After: Germany's Historical Imaginary. Londres: Routledge, 2008.

ELTON, Geoffrey Rudolph. A Europa durante a Reforma 1517-1559: as Reformas Religiosas. Lisboa: Editorial Presença, 1982.

EVANS, Richard J. The Coming of the Third Reich. Nova York: Penguin Books, 2003.

The Third Reich at War: How the Nazis Led Germany from Conquest to Disaster.

Nova York, Londres: Penguin, 2009. 
The Third Reich in Power 1933-1939. Nova York: Penguin Books, 2005.

FERRO, Marc. Cinéma et histoire. Paris: Gallimard, 2009.

FEST, Joachim C. Hitler. Tradução: Ana Lucia Teixeira Ribeiro, Antônio Nogueira Machado, Antônio Pantoja, Francisco Manuel da Rocha Filho. Rio de Janeiro: Nova Fronteira, 1997.

FOUCAULT, Michel. Em defesa da sociedade: curso no Collège de France (1975-1976). Tradução: Maria Ermantina Galvão. São Paulo: Editora WMF, Martparacelsins Fontes, 2010.

Histoire de la sexualité 1: la volonté de savoir. Paris: Gallimard, 2003.

Microfísica do poder. Tradução: Roberto Machado. Rio de Janeiro: Edições Graal, 2004.

Segurança, território, população. Tradução: Eduardo Brando. São Paulo: Martins Fontes, 2008.

FOX, Jo. Filming Women in the Third Reich. Oxford: Berg, 2000.

FREUD, Sigmund. Além do princípio do prazer, in Obras psicológicas completas de Sigmund Freud Volume XVIII. Tradução: José Octávio de Aguiar Abreu Christiano Monteiro Oiticica. Rio de Janeiro: Imago, 1996.

Alguns mecanismos neuróticos no ciúme, na paranoia e no homossexualismo in FREUD, Sigmund. Obras psicológicas completas de Sigmund Freud: Volume XVIII. Tradução: José Octávio de Aguiar Abreu, Christian Monteiro Oiticica. Rio de Janeiro. Imago, 1996.

O caso Schreber, in Obras psicológicas completas de Sigmund Freud Volume XII. Tradução: José Octávio de Aguiar Abreu e Christiano Monteiro Oiticica. Rio de Janeiro: Imago, 1996.

Os chistes e sua relação com o inconsciente in FREUD, Sigmund. Obras psicológicas completas de Sigmund Freud Volume VIII. Tradução: Margarida Salomão. Rio de Janeiro: Imago, 1996.

Conferências introdutórias sobre a Psicanálise (Partes I e II): A censura nos sonhos: Conferência IX in FREUD, Sigmund. Obras psicológicas completas de Sigmund Freud Volume XXII. Tradução: José Octávio de Aguiar Abreu e Christiano Monteiro Oiticica. Rio de Janeiro Imago, 1996.

O ego e o id in FREUD, Sigmund. Obras psicológicas completas de Sigmund Freud Volume XIX. Tradução: José Octávio de Aguiar Abreu. Rio de Janeiro: Imago, 1996.

Escritores criativos e devaneio, in FREUD, Sigmund. Obras psicológicas completas de Sigmund Freud Volume IX. Tradução: Maria Aparecida Moraes Rego. Rio de Janeiro: Imago, 1996.

O 'estranho', in Obras psicológicas completas de Sigmund Freud Volume XVII. Tradução: José Luiz Meurer. Rio de Janeiro: Imago, 1996.

O inconsciente in FREUD, Sigmund. Obras psicológicas completas de Sigmund Freud: Volume XIV. Tradução: José Octávio de Aguiar Abreu, Christiano Monteiro Oiticica. Rio de Janeiro: Imago, 1996.

A interpretação dos sonhos in FREUD, Sigmund. Obras psicológicas completas de Sigmund Freud: Volume IV. Tradução: José Octávio de Aguiar Abreu, Christiano Monteiro Oiticica. Rio de Janeiro: Imago, 1996.

Novas Conferências introdutórias sobre a Psicanálise: Feminilidade: Conferência 
XXXIII in FREUD, Sigmund. Obras psicológicas completas de Sigmund Freud: Volume XXII. Tradução: José Luiz Meurer. Rio de Janeior Imago, 1996.

Personagens psicopáticos no palco, in FREUD, Sigmund. Obras psicológicas completas de Sigmund Freud Volume VIII. Tradução: José Octávio de Aguiar Abreu, Christiano Monteiro Oiticica. Rio de Janeiro: Imago, 1996.

Psicologia de grupo e a análise do ego in FREUD, Sigmund. Obras psicológicas completas de Sigmund Freud Volume XVIII Tradução: José Octávio de Aguiar Abreu, Christiano Monteiro Oiticica. Rio de Janeiro: Imago, 1996,

Totem e tabu: algumas concordâncias entre a vida psíquica dos homens primitivos e dos neuróticos. Tradução: Paulo César de Souza. São Paulo: Penguin Classics, Companhia das Letras, 2013.

Uma criança é espancada, in Obras psicológicas completas de Sigmund Freud Volume XVII. Tradução: José Luiz Meurer. Rio de Janeiro: Imago, 1996.

GAY, Peter. A cultura de Weimar. Tradução: Laura Lúcia da Costa Braga. Rio de Janeiro: Paz e Terra, 1978, 154-6

GIESEN, Rolf. Nazi Propaganda Films: a History and Filmography. Jefferson: McFarland, 2003.

GOBINEAU, Arthur de. The Inequality of Human Races. Londres: William Heinemann, 1915 (versão digitalizada pelo Internet Archive com fundos da University of North Carolina at Chapel Hill, 2011).

GOETHE, Johann Wolfgang. Lamartine. Porto Alegre: Editorial Curiosidade, 1942.

GRAMSCI, Antonio. O leitor de Gramsci: escritos escolhidos 1916-1935. Tradução: Carlos Nelson Coutinho (org.) Rio de Janeiro: Civilização Brasileira, 2011.

GREIMAS, Algirdas Julius. Semântica estrutural: pesquisa de método. Tradução: Haquira Osakabe, Izidoro Blikstein. São Paulo: Cultrix e Editora Universidade de São Paulo, 1976.

GREIMAS, Algirdas Julius; COURTES, J. Dicionário de semiótica. Tradução: Alceu Dias Lima, Diana Luz Pessoa de Barros, Eduardo Peñuela Cañizal, Eduardo Lopes, Ignacio Assis da Silva, Maria José Castagnetti Sombra, Tieko Yamaguchi Miyazaki. São Paulo: Contexto.

GUNNING, Tom. The Films of Fritz Lang. Londres: British Film Institute, 2000.

HAKE, Sabine. Popular Cinema of the Third Reich. Austin: University of Texas Press, 2001.

HASKELL, Molly. From Reverence to Rape: the Treatment of Women in the Movies. Chicago: University of Chicago Press, 1987.

HAVER, Ronald. David O. Sezlnick's Hollywood. Nova York; Alfred Knopf, 1980.

HERF, Jeffrey. O inimigo judeu: Propaganda nazista durante a Segunda Guerra Mundial e o Holocausto. Tradução: Walter Solon. São Paulo: Edipro, 2014.

Reactionary Modernism: Technology, Culture and Politics in Weimar and the Third Reich. Cambridge: Cambridge University Press, 1998.

HILLENBRAND, F.K.M. Underground Humour in Nazi Germany 1933-1945. Londres, Nova York: Routledge, 1995.

HITCHCOCK, Alfred. Hitchcock por Hitchcock: Coletânea de Textos e Entrevistas. Tradução Vera Lúcia Sodré. Rio de Janeiro; Imago, 1998.

HOFFMANN, Hilmar. The Triumph of Propaganda Film and National Socialism, 19331945. Tradução: John A. Broadwin, V. R. Berghahn. Oxford: Birghahn Books, 
1996.

HULL, David Stewart. Film in the Third Reich: a Study of the German Cinema 1933-1945. Berkeley: University of California Press, 1969.

HUYSSEN, Andreas. After the Great Divide: Modernism, Mass Culture, Postmodernism. Bloomington, Indiana: University of Indiana Press, 1986.

HALLIDAY, Jan. Conversations avec Douglas Sirk. Tradução: Serge Grünberg. Paris: Cahier du cinéma.

JUNG, Carl Gustav. Aspectos do drama moderno. Tradução: Lúcia Mathel Endlich Orth. Petrópolis: Vozes, 2012.

Civilização em transição. Tradução: Lúcia Mathel Endlich Orth. Petrópolis: Vozes, 2013.

Os arquétipos e o inconsciente coletivo. Tradução: Maria Luiza Appy, Dora Mariana R. Ferreira da Silva. Petrópolis: Vozes, 2014.

JUNGER, Ernst. Tempestades de aço. Tradução: Marcelo Backes. São Paulo: Cosac Naify, 2013.

KALLIS, Aristotle A. A. Nazi Propaganda and the Second World War. Hampshire: Palmgrave Macmillan, 2005.

KELSEN, Hans. A democracia. Tradução: Ivone Castilho Benedetti, Jefferson Luiz Camargo, Marcelo Brandão Cepolla, Vera Barkow. São Paulo: Martins Fontes, 2000.

KERSHAW, Ian. Hitler. Tradução: Pedro Maia Soares. São Paulo: Companhia das Letras, 2010.

KIRSTEIN, Lincoln; LEYDA, Jay; LOSEY, Mary; STEBBINS, Robert; STRASBERG, Lee. Films - a Quaterly of Discussion and Analysis. Nova York: Arno Press, 1968.

KLEIN, Melanie. Contribuições à Psicanálise. Tradução: Miguel Maillet. São Paulo: Editora Mestre Jou, 1970.

KLEMPERER, Victor. LTI: a linguagem do Terceiro Reich. Tradução: Miriam Bettina Paulina Oelsner. Rio de Janeiro: Contraponto, 2009.

KOEPNICK, Lutz. The Dark Mirror: German Cinema between Hitler and Hollywood. Berkeley, Los Angeles: University of California Press, 2002.

KRACAUER, Siegfried. From Caligari to Hitler: a Psychological History of the German Film. Princenton: Princenton University Press, 2004.

O ornamento da massa. Tradução: Carlos Eduardo Machado e Marlene Holzhausen. São Paulo: Cosacnaify, 2009.

The Salaried Masses: Duty and Distraction in Weimar Germany. Tradução:

Quintin Hoare. Nova York: Verso, 1998.

KREIMEIER, Klaus. The Ufa Story: a History of Germany Greatest Film Corporation, 19181945. Tradução: Robert Kimbler, Rita Kimbler. Berkeley, Los Angeles: University of California Press, 1999.

KRISTEVA, Julia, Pouvoirs de l'Horreur: Essai sur l'abjection. Paris: Édition du Seuil, 1980.

LACAN, Jacques. Des Noms-du-Père. Paris: Éditions du Seuil: 2005. Le seminaire Livre XX Encore 1972-1973. Paris: Éditions de Seuil, 1999. Livre XI Les quatre concepts fondamentaux de la psychanalyse. Paris: Éditions du Seuil, 1990. O Seminário livro 4: a relação de objeto. Tradução: Dulce Duque Estrada. Rio 
de Janeiro: Zahar, 1995.

O seminário livro 5: as formações do inconsciente. Tradução: Vera Ribeiro. Rio

de Janeiro. Zahar, 1999.

O seminário Livro 6: o desejo e sua interpretação. Tradução: Claudia Berliner.

Rio de Janeiro: Zahar, 2016.

O seminário, livro 7: a ética na psicanálise, 1959-1960. Tradução: Antônio

Quintet. Rio de Janeiro: Zahar, 2008.

O seminário Livro 8: a transferência. Tradução: Dulce Duque Estrada. Rio de Janeiro: Zahar, 2016.

O seminário 10: a angústia. Tradução: Vera Ribeiro. Rio de Janeiro: Zahar,

2005.

O seminário livro 16: de um Outro ao outro. Tradução: Vera Ribeiro. Rio de Janeiro: Zahar, 2008.

O Seminário livro 18: de um discurso que não fosse semblante (1971). Tradução: Vera Ribeiro. Rio de Janeiro: Zahar, 2009.

Zahar, 2012.

LACLAU, Ernesto. Politics and Ideology in Marxist Theory: Capitalism, Fascism, Populism. Londres: NBL, 1977.

LACOUE-LABARTHE, Philippe: NANCY, Jean-Luc. O mito nazista seguido de O espírito do nacional-socialismo e o seu destino. Tradução: Márcio Seligmann Silva. São Paulo: Iluminuras, 2002.

LAPLANCHE, Jean. Vie et mort em psychanalyse. Paris. Flammarion, 2001.

LAPLANCHE, Jean: PONTALIS, Jean-Bertrand. The Language of Psychoanalysis. Tradução: Donald Nicholson Smith. Londres: Carnac Books, 1988.

LEBEL, Jean-Patrick. Cinema e ideologia. Tradução: Jorge Nascimento. Lisboa: Editorial Estampa, 1975.

LEISER, Erwin. Nazi Cinema. Tradução: Gertrud Mander, David Wilson. Nova York: Collier Books, 1974.

LIONEL, Richard. A República de Weimar, 1919-1933. Tradução: Jônatas Batista Neto. São Paulo: Companhia das Letras, 1988.

LIPOVETSKY, Gilles: SERROY, Jean. A estetização do mundo: Viver na era do capitalismo artista. Tradução: Eduardo Brandão. São Paulo: Companhia das Letras, 2015.

LONGERICH, Peter. Heinrich Himmler. Tradução: Jeremy Noakes, Lesley Sharpe. Oxford: Oxford University Press, 2012.

2014. Joseph Goebbels. Tradução: Luiz A. de Araújo. Rio de Janeiro: Objetiva,

LORD, Walter. A Night to Remember. Nova York: Bantam Books, 1977.

MALAPARTE, Curzio. Kaput. Tradução: Cesare Foligno. Nova York: Nyrb, 2005.

MANN, Michael. Fascistas. Tradução: Clóvis Marques. Rio de Janeiro: Record, 2008.

MARCUSE, Herbert. Negations: Essays in Critical Theory. Londres: MayFly, 2009.

One-dimensional Man: Studies in the ideology of advanced industrial society. Londres e Nova York: Routledge, 2002.

Reason and Revolution: Hegel and the Riseof Social Theory. Nova York: Humanity Books, 1999.

METZ, Christian. Psychoanalysis and Cinema: the Imaginary Signifier. Tradução: Celia 
Britton, Annwyl Williams, Brewster, Alfred Guzzetti. Londres: Macmillan Press, 1983.

MILLER, Jacques-Allain. Percurso de Lacan: uma introdução. Tradução: Ari Roitman. Rio de Janeiro: Zahar, 1987.

MOLTKE, Johannes von. No Place Like Home: Locations of Heimat in German Cinema. Berkeley, Los Angeles: University of California Press, 2005.

MORIN, Edgar. Les stars. Paris: Éditions du Seuil, 1972.

MORLEY, Sheridan. Tales From the Hollywood Raj: the British in California. Londres: Coronet Books, 1985.

NEALE, Steve. Genre and Hollywood. Londres e Nova York: Routledge, 2000.

O'BRIEN, Mary Elizabeth. Nazi Cinema as Enchantment: the Politics of Entertainment in the Third Reich. Rochester, Nova York: Camden House, 2004.

PARKER, Geoffrey (ed). The Thirty Years' War. Londres e Nova York: Routledge, 1987.

PASQUINO, Gianfranco. Curso de ciência política. Tradução: Ana Sassetti da Mota. Cascais: Principia, 2002.

PEREIRA, Wagner Pinheiro. O poder das imagens: cinema e politica nos governos de Adolf Hitler e de Franklin D. Roosevelt (1933-1945). São Paulo: Alameda, 2012.

PETLEY, Julian. Capital and Culture: German Cinema 1933-45. Londres: British Film Institute (BFI), 1979.

PRIBAM, E. Deidre (ed.). Female Spectactors: Looking At Film and Television. Londres e Nova York: Verso, 1988.

RASPE, Rudolph Erich. The Surprising Adventures of Baron Munchausen. Project Gutenberg EBook, 2006.

REESE, Dagmar. Growing Up Female in Nazi Germany. Tradução: William Templer. Michigan: University of Michigam Press, 2009.

REICH, Wilhelm. The Mass Psychology of Fascism. Nova York: Farrar, Straus and Giroux, 1985.

RENTSCHLER, Eric (ed.). German Film \& Literature: Adaptations and Transformations. Nova York, Londres: Methuen, 1986.

The Ministry of Illusion: Nazi Cinema and its Afterlife. Cambridge: Harvard University Press, 2002.

ROGOWSKI, Christian (ed.) The Many Faces of Weimar Cinema: Recovering Germany's Filmic Legacy. Rochester, Nova York: Camden House, 2010.

ROMANI, Cinzia. Tainted Goddesses: Female Film Stars of the Third Reich. Tradução: Robert Connolly. Roma: La Moderna, 2001.

ROUDINESCO, Elisabeth. A parte obscura de nós mesmos: uma história dos perversos. Tradução: André Telles. Rio de Janeiro: Zahar, 2008.

ROUDINESCO, Elisabeth: PLON, Michel. Dicionário de psicanálise. Tradução: Vera Ribeiro, Lucy Guimarães. Rio de Janeiro: Zahar, 1998.

SARTRE, Jean-Paul. Réflexions sur la question juive. Paris: Gallimard, 2009.

SCHICKEL, Richard. The Stars. Nova York: Bonanza Books, 1962.

SCHMITT, Carl. Political Theology: Four Chapters on the Concept of Sovereignty. Tradução: George Schwab. Chicago: University of Chicafo Press, 2005.

State, Movement, People: the Triadic Structure of Politica Unity (1933) / The Question of Legality 1950). Tradução Simona Draghici. Corvalis: Plutarch Press, 2001. 
The Concept of the Political. Tradução: George Schwab. Chicago: University of Chicago Press, 2007.

SCHOEPS, Karl-Heinz. Literature and Film in the Third Reich. Tradução: Kathleen M. Dell'Oro. Rochester, Nova York: Camdem House, 2013.

SCHULTE-SASSE, Linda. Entertaining the Third Reich: Illusions of Wholeness in Nazi Cinema. Durhan, Londres: Duke University Press, 1996.

SHIRER, William A. Berlim Diary: the Journal of a Foreign Correspondent, 1934-1941. Baltimore: Johns Hopkins University Press, 2002.

The Rise and Fall of the Third Reich: a History of Nazi Germany. Nova York: Simon\&Schuster, 2011.

SINGER, Claude. Le Juif Süss et la propagande nazie: la histoire confisquée. Paris: Les Belles Letres, 2003.

SLOTERDIJK, Peter. Crítica à razão cínica. Tradução: Marco Casanova, Paulo Soethe, Pedro Costa Rego, Maurício Mendonça Cardozo, Ricardo Hiendlmayer. São Paulo: Estação Liberdade, 2012.

SONTAG, Susan. Fascinante Fascismo in Sob o signo de Saturno. Tradução Ana Maria Capovilla. L\&PM, 1980.

SORLIN, Pierre. Sociologie du cinema: Ouverture pour l'histoire de demain. Paris: $6^{\circ}$ Aubier Montaigne, 1977.

SPEER, Albert. Inside the Thrid Reich: Memoirs. Tradução: Richard Winston, Clara Winston. Nova York, 1981.

Os diários secretos de Spandau. Tradução: Guilherme da Nóbrega Cesarino. Rio de Janeiro: Editora Arte Nova, 1995.

STEIGMANN-GALL, Richard. The Holy Reich: Nazi Conceptions of Christianity, 19191945. Cambridge: Cambridge University Press, 2003.

STEINBERG, S. H. The 'Thirty Years War' and the Conflict for European Hegemony 16001660. Londres: Edward Arnold Publishers, 1966.

STROBL, Gerwin. The Swastika and the Stage: German Theatre and Society, 1933-1945. Cambridge: Cambridge University Press, 2009.

TAL, Ulrich. Religion, Politics and Ideology in the Third Reich: Selected Essays. Londres e Nova York: Routledge, 2004.

TAYLOR, Richard. Film Propaganda: Soviet Russia and Nazi Germany. Londres, Nova York: I. B. Taurus, 2009.

TEGEL, Susan. Jew Süss: Life Legend, Fiction, Film. Londres, Nova York: Continuum, 2011.

Nazis and the Cinema. Londres: Hambledon, 2007.

THEWELEIT, Klaus. Male Fantasies: Volume 1: Women, Floods, Bodies, History. Tradução: Stephen Conway, Erica Carter, Chris Turner. Minneapolis: University of Minnesota Press, 2010.

Male Fantasies: Volume 2: Psychoanalyzing the White Terror. Tradução: Stephen Conway, Erica Carter, Chris Turner. Minneapolis: University of Minnesota Press, 2010.

THOMASSEAU, Jean-Marie. O melodrama. Tradução: Cláudia Braga e Jacqueline Penjon. São Paulo: Perspectiva, 2012.

TODOROV, Tzvetan. As estruturas narrativas. Tradução: Ligia Perrone-Moisés. São Paulo: Perspectiva, 2013. 
Introdução à literatura fantástica. Tradução: Maria Clara Correa Castello. São Paulo: Perspectiva, 2014.

TOOZE, Adam. The Wages of Destruction: the Making and the Breaking of the Nazi Economy. Nova York: Penguin, 2006.

TOTEBERG, Michael (org). Rainer Werner Fassbinder: a anarquia da fantasia - ensaios, anotações de trabalho, conversas e entrevistas. Tradução: Sonia Baldessarini, Clóvis Marques, 1988.

VAIZEY, Hester. Surviving Hitler's War: Family Life in Germany, 1939-48. Hampshire: Palgrave MacMillam, 2010.

VIRILIO, Paul. Guerra e cinema. Tradução: Paulo Roberto Pires. São Paulo: Boitempo, 2005.

VOEGLIN, Eric. As religiões políticas. Tradução: Teresa Marques da Silva. Lisboa: Vega/Passagens, 2002.

WELCH, David. Propaganda and the German Cinema 1933-1945. Londres: I. B. Taurus, 2001. 2002.

WINKEL, Roel Vande, WELCH, David (eds.). Cinema and the Swastika: the International Expansion of the Third Reich Cinema. Hampshire: Palgrave Macmillan, 2011.

ŽIŽEK, Slavoj (org.) Um mapa da ideologia. Tradução: Vera Ribeiro. Rio de Janeiro: Contraponto, 1996.

Looking Awry: an Introduction to Jacques Lacan through Popular Culture. Cambridge e Massachusetts: October Book/ Massachusetts Institute of Technology, 1991.

The Sublime Object of Ideology. Londres, Nova York: Verso, 2008.

ZWEIG, Stefan. The World of Yesterday. Tradução: Anthea Bell. Nebraska: University of Nebraska Pres, 2011. 


\section{Indíce onomástico}

(pessoas, obras artísticas, gêneros e instituições / n: nota / italic: imagem)

... reitet für Deutschland (1941), 52n, 116n, 291.

\section{A}

A Night to Remember (Somente Deus por Testemunha, 1958), 225, 227n.

Abscheidswalzer (1934), 244, 246, 289.

Adeus, Francisca, ver Aufwiedersehen, Franziska (1941).

Adorno, Theodor W., 28, 91, 114, 123, 175, 176n, 179-81, 246, 293.

Agamben, Giorgio, 86, 96n, 235.

Albers, Hans, 19, 126, 161, 166, 198-91, 193, 207, 226, 227n, 282-3.

Alô Janine!, ver Hallo Janine (1939).

Alte und der junge König, Der (1935), 101, 153n, 289.

Althusser, Louis, 38n.

Andersen, Lale, 154n. Andreas Schüller (1942), 54n, 291.

Angústia em Paris, ver Verwehte Spuren (1938). Annelie (1941), 159, 291.

Antonioni, Michelangelo, 79 .

Arendt, Hannah, 30, 178, 180n, 196.

Arnaud, Étienne. 213.

Assim acaba um grande amor, ver So endete eine Liebe (1934).

Atlantic (1929), 213, 229.

Aufwiedersehen, Franziska (1941), 108, 116n, 232, 291.

\section{B}

Baarova, Lida, 126.

Baile noturno, ver Es war eine rauschende Ballnacht (1939).

Baker, Roy, 225.
Baky, Josef von, 19, 35, 39,

156, 161n, 291-2.

Balz, Bruno, 136, 157,

120n.

Bauer, Wilhelm, 53n,

226n.

Bavaria Film, 27n.

Bdk (Bund für deutsche

Kirche), 11, 62.

BdM (Bund deutscher

Mädel), 11, 111.

Behn-Grund, Friedl, 21,

227.

Bekennende Kirche, 11, 63.

Benjamin, Walter, 123,

256n.

Berg, The (1929), 213.

Bergfilm, 11, 170.

Bernhardt, Curtis, 252,

289.

Bertram, Hans, 144n, 290.

Besatzung Dora (1943), 139,

254, 292.

Bismark (1940), 52n, 278,

290.

Blaufuchs, Der (1939), 119,

126n, 134n, 282, 290.

Boese, Carl, 280, 290.

Bohnen.Michael, 19, 215n, 194.

Bohnert, Jolly, 21, 221, 229.

Bolváry, Géza von, 119,

244, 288-9.

Bomben auf Monte Carlo (1931), 201.

Borsody, Eduard von, 108, 232, 291.

Böttger, Fritz, 220.

Bratt, Harald, 215n.

Brauer, Peter Paul, 48.

Breuer, Siegfried, 79n.

Brix, Hermann, 221.

Brüning, Heinrich, 261, 263n.

Brunsch, Fritz, 144n, 291.

Bukovics, Toni von, 220.

Bund deutscher Mädel, ver

BdM.

Bund für deutsch Kirche, ver BdK.
Burg, Monica, 221.

Bürger Bertolt, ver

Kästner, Erich.

Bürger, Gottfried August, 159n.

C

Cabinet des Doctor Caligari,

Das (1920), 97.

Calvino, João, 57.

Canetti, Elias, 191, 239.

Capriccio (1938), 155n, 290.

Caprichos, ver Capriccio

(1938).

Carl Peters (1941), 52n, 201, 217, 227, 278, 291.

Casa de Rothschild, A, ver

House of Rothschild, The

(1934).

Caspar, Horst, 271-2, 276.

Churchill, Winston, 215,

218.

Cidade da ilusão, ver goldene Stadt, Die (1942).

Continental Kunstfilm, 213.

Cooper, Gary, 80n.

Corriere Padano, 79n

Crawford, Joan, 118.

Crepúsculo, ver Herrscher,

Der (1937).

D

Dachau, 181n, 262n.

Dagover, Lil, 115n.

Dahlke, Paul, 79n.

Damals (1943), 119n, 126n,

292.

Dannemann, Karl, 229.

Dean, Basil, 46.

Deleuze, Gilles, 77, 258,

286.

Deltgen, René, 79n.

Desespero de Veronica Voss,

$O$, ver Sehnsucht der

Veronika Voss, Die (1981).

Deulig-Woche, 143n.

Deutsche Wochenshau

$\mathrm{GmbH}, 143 \mathrm{n}$.

Deutsche Wochenshau, 15, 29, 140, 142-5, 225. 
DFO (Deutscher Frauen

Orden Rotes Haken Kreuz),

11, 111n.

Diário de uma garota

perdida, ver Tagebüch einer Verlorenen (1929).

Die Entlassung (1942), 52n, 278, 291.

Diehl, Karl Ludwig, 215n.

Diertele, William, 46.

Diesel (1942), 54n, 291.

Diessl, Gustav, 272.

Dietrich, Marlene, 119, 122, 126, 128, 131n.

Dönitz, Karl, 25, 262, 271.

Dr. Mabuse, o jogador, ver

Dr. Mabuse, der Spieler.

Dr. Mabuse, der Spieler

(1922), 99.

Dreyer, Carl Theodor, 243.

Dupont, Ewald André, $213 n$.

\section{E}

E o vento levou, ver Gone with the Wind (1939).

Eduardo VII, 216n.

Eichmann, Adolf, 181n.

Ein idealer Gatte (1935),

244, 289.

Ein Leben lang (1940), 280,

290.

Ein Mann auf Abwegen

(1940), 201, 291.

Eine Nacht in Mai (1938),

155n, 280, 290.

Elsholtz, Peter, 221.

Elvey, Maurice, 46.

Emo, Emerich Wojtek (E.

W.), 52n, 292.

Encouraçado Potemkin, O, (1925), 48.

Engel, Erich, 244, 290.

Engelmann, Andrews,

162.

Es war eine rauschende

Ballnacht (1939), 119, 134n,

282, 290.

Estree Studio, 213n.

Ewige Jude, Der (1941), 42, 169, 290.

Ewiger Rembrandt (1941), 52n, 291.

\section{$\mathbf{F}$}

F.P.1 antwortet nicht!, 245.
Fährmann Maria (1936),

244, 289.

Fassbinder, Rainer

Werner, 80n, 244n.

Feldzug in Polen (1940),

144n, 290.

Felinau, Pelz von, 215n.

Fernau, Rudolf, 79n.

Feuchtwanger, Lion, 46.

Feuertaufe, Die (1940),

144n, 290.

Feuerzangenbowle, Die

(1944), 283-5, 292.

Filho pródigo, $O$, ver

verlorene Sohn, Der (1935).

Film-Kurier, ver Illustrierter

Film-Kurier.

Fleming, Victor, 214, 274.

Forst, Willi, 79n, 126, 280,

9.

Fox tönende Wochenshau,

143n.

Frau am Steuer (1939),

110n, 290.

Frau meiner Träume, Die

(1944), 280, 292.

Frauen sind doch bessere

Diplomaten (1941), 280,

291.

Freud, Sigmund, 75, 93-5,

$117,138,171,173,180$,

182n, 187, 189, 203-4, 260

Friedemann Bach (1941),

278, 291.

Friedericus, der alte Fritz

(1936), 52n, 289.

Friedericusfilm, 52n, 276.

Friedrich Schiller, der

Triumph eines Genies

(1940), 52n, 272, 290.

Friedrich, Hieronymous

Karl, 159.

Fritsch, Willi, 199.

Froelich, Carl, 52n, 107n, 119, 161, 297, 282, 290.

Foucault, Michel, 73, 84,

86 n.

Fuchs von Glenarvon, Der (1940), 79n, 217, 290.

Funk, Sophie, 114.

Fürbringer, Ernst, 220, 233, 229, 234.

Futilidade, ou o naufrágio do

Titan, ver Futility, or the

Wreck of the Titan (1898).

Futility, or the Wreck of the
Titan (1898), 212.

G

Gabinete do Dr. Caligari, O, ver Cabinet des Doctor

Caligari, Das (1920).

Gable, Clark, 80n.

Garbo, Greta, 117-8, 128.

Gasparone (1937), 280, 289.

Gaumont, 212.

Gay, Peter, 185-6.

Gebühr, Otto, 52n.

Geheimakte WB I (1942),

53n, 226, 291.

Geniusfilm, 11, 52, 101, 170, 231, 276.

Genschow, Fritz, 222.

George, Heinrich, 19, 44,

47, 49, 79, 126, 199, 271-2.

Gibson, Dorothy, 213.

Gobineau, Arthur de,

188n.

Goebbels, Josef, 25n, 27,

30, 43, 47-8, 48n, 53, 80n,

$118,120 \mathrm{n}, 126 \mathrm{n}, 159,161 \mathrm{n}$,

$167,168 \mathrm{n}, 199,217-9$, 223-

5, 226n, 228, 242, 255, 258,

261, 265n, 269-71, 274-5,

277, 281n.

Goebbels, Magda, 114.

Goedecke, Heinz, 151.

Goethe, Johann Wolfgang,

57.

Gold (1934), 252, 289.

Goldene Stadt, Die (1942),

49n, 291, .

Gone With the Wind (1939),

214, 274.

Göring, Emmy, 114.

Göring, Hermann, 271.

Gottschalck, Joachim,

244n.

Goulding, Edmund, 233.

Gramsci, Antonio, 38n,

183.

Grand Hotel (1932), 233.

Grande Hotel, ver Grand

Hotel (1932).

Grande rei, $O$, ver große

König, Der (1940).

Große Freiheit Nr 7 (1944),

116n, 201, 282, 292.

Große König, Der (1942),

52n, 110, 272, 291.

Große Liebe, Die (1942), 9-

$10,19,39,105-57,232,273$, 
279, 282, 291-2.

Grosz, George, 239.

Gründgens, Gustaf, 79n.

Guattari, Felix, 258, 286.

$\mathbf{H}$

Habanera, La (1937), 79n, 119, 126n, 132n, 289.

Hallo, Janine! (1939), 280, 290.

Hans Westmar: einer von

Vieler (1933), 25n, 53n, 272, 276, 289.

Hansen, Max, 120n.

Hansen, Rolf, 19, 39, 105,

119n, 232, 291, 292.

Harlan, Veit, 19, 31n, 34,

39, 41, 42n, 42-3, 47-9, 52n,

66-7, 80n, 81, 101, 161,

$163 n, 227 n, 2670,272$, 290-

2.

Hartl, Karl, 53n, 246, 252,

280, 289-90, 292.

Harvey, Lilian, 126, 155n, 199.

Hauff, Wilhelm, 46, 48.

Häussler, Richard, 79n.

Heiberg, Kirsten, 21, 220,

229, 233, 234.

Heimat (1938), 119, 126n,

132n, 169, 290

Heimatfilm, 13, 169n.

Heimkehr (1941), 170n, 215,

281, 291.

Helbig, Heinz, 54n, 290.

Henlein, Peter, 52n.

Herrscher, Der (1937), 49n,

289.

Herz der Königin, Das

(1940), 53n, 217, 290.

Heydrich, Lina, 114.

Himmler, Heinrich, 120n, 271.

Himmler, Margarete, 114.

Hindenburg, Paul von,

263n.

Hippler, Fritz, 144n, 169,

290

Hitchcock, Alfred, 214.

Hitler, Adolf, 11, 52, 63,

$105,112,115 \mathrm{n}, 119 \mathrm{n}, 137$,

145n, 156, 169n, 182, 216,

218, 231, 244n, 250, 263-4,

270, 274-5, 278, 281, 289.

Hitlerjunge Quex (1933),

25n, 52n, 273n, 289.
Hitlerjugend, ver $\mathrm{HJ}$.

HJ (Hitlerjugend), 13, 111n,

188, 189n.

Hoppe, Marianne, 126.

Hörbiger, Attila, 280.

Hörbinger, Paul, 107.

Horkheimer, Max, 175,

176n, 177.

Horney, Brigitte, 19, 162,

205.

Höß, Rudolph, 180n.

Hotel Sacher (1938), 244,

290.

House of Rothschild, The

(1934), 46.

Hugenberg, Alfred, 160.

I

Igreja Confessional, ver

Bekennende Kirche.

Illustrierter Film-Kurier,

224, 228n.

Immensee (1943), 49n, 292.

Imperador da Califórnia, $\mathrm{O}$,

ver Kaiser von Kalifornien

(1936).

In Nacht und Eis (1912),

213, 228.

Irmen-Tschet, Konstantin, $19,290$.

J

Jacoby, Georg, 280, 156n, 289-92.

Jäger, Malte, 19, 44, 49, 64, 103

Jannings, Emil, 79n, 126.

Jew Süss (1934), 46.

Johst, Hanns, 48n.

Jud SüB (1940), 19, 39, 31n, 41-103, 166, 169, 278.

Jud SüB (romance), 46.

$J u d e u$ errante, $O$, ver

Wandering Jew, The (1933).

Judeu eterno, $O$, ver ewige

Jude, Der (1941).

Judeu Suss, O, ver Jew Süss

(1934).

Jugend (1938), 81n, 290.

Julika, ver Julika, Die

(1936).

Julika, Die (1936), 280, 290.

Jung, Carl Gustav, 182,

$188 \mathrm{n}$.

Junger, Ernst, 111.

Juventude Ardente, ver
Jugend (1938).

Juventude Hitlerista, ver HJ

\section{K}

Kaiser von Kalifornien, Der (1936), 227n, 278, 289.

Kampfzeitfilm, 13, 52n, 278.

Kästner, Erich, 159-61,

206.

Käutner, Helmut, 108n,

116n, 201, 282, 291, 292.

Kelsen, Hans, 61n, 240.

Kimm, Jean, 213n.

Kimmich, Max, 79n, 272,

290-1.

Klein, Melanie, 73.

Klemperer, Victor, 177,

249, 279n.

Klinger, Liselotte, 222.

Klingler, Werner, 21, 214,

228n, 292.

Klöpfer, Eugen, 19, 44, 49,

79.

Kolberg (1945), 34, 164n,

269-77, 292.

Komödianten (1941), 53n,

291.

Kora Teri (1940), 280, 291.

Körner, Theodor, 271.

Kracauer, Siegfried, 26, 31,

97.

Krau $\beta$, Werner, 19, 44, 49, 79, 88, 90, 126.

Krien, Werner, 19, 290.

Kulturfilm, 28n.

Kultutprotestantismus, 13, 63.

\section{L}

Lacan, Jacques, 37n, 38n, $75,117,124,154-5,182 n$, 186, 197.

Laclau, Ernesto, 38n.

Ladrão de Bagdá, $O$, ver

Thief of Bagdad, The (1941).

Lamprecht, Gehard, 53n,

291.

Langen, Carl Friedrich

Freiherr von, 52n.

Leander, Zarah, 19, 81n,

105-7, 110, 119-23, 126-

$8,40,135,138,155-6,199$,

282.

Lei de Cinema do Reich

(1934), 28n. 
Leinen aus Irland ("Linho

da Irlanda", 1939), 59n,

290.

Liebeneiner, Wolfgang,

52n, 161, 278, 290-1.

Lied der Wüste, Das (1939),

119, 126n, 290.

Life of Emile Zola, The

(1937), 46.

Liga para Igreja Alemã,

ver Bdk.

Lili Marleen, 151n.

Loos, Theodor, 220.

Loucuras de Monte Carlo, ver Bomben auf Monte

Carlo (1931).

Loyalties (1933), 46

Lueger, Karl, 52n.

Lutero, Martinho, 56-7, 59, 62.

M

Mädchen Johanna, Das

(1935), 53n, 289.

Maisch, Herbert, 52n, 53n, 272, 290-1.

Malaparte, Curzio, 181,

248.

Mann, der Sherlock Holmes

war, Der (1937), 201, 290.

Manz, Felix, 57.

Marcuse, Herbert, 86, 176-

7.

Marian, Ferdinand, 19, 44, 47, 75, 78-80, 116, 162.

Mann, Thomas, 187.

Marin, Paul, 108n, 119,

290.

Marx, Karl, 187.

Mascarada, ver Maskerade

(1934).

Maskerade (1934), 280, 292.

Mein Leben für Irland

(1941), 217, 272, 291.

Meisel, Kurt, 272.

Méliès, Georges, 160,

$164 n$.

Mendes, Lothar, 46.

Metropolis (1927), 251.

Metz, Christian, 171-2.

Metzger, Ludwig, 48.

Meyendorff, Irene von,

273.

Meyer, Johannes, 52n, 289.

Ministério do Reich para

Esclarecimento Popular e
Propaganda, ver RMVP.

Misu, Mime, 213.

Mocidade heroica, ver

Hitlerjunge Quex (1933).

Müller, Renate, 126, 244n,

281.

Müller, Traugott, 278, 291.

Münchhausen (1943), 9-10,

19, 35, 39, 159-210, 282,

292.

Münzer, Thomas, 57.

\section{$\mathbf{N}$}

Nagy, Käthe von, 126.

Nationasozialistische

Deutsche Arbeitopartei

(Partido Nacional

Socialista dos

Trabalhadores Alemães), ver NSDAP.

Negri, Pola, 126.

Neubar, Caroline, 53n.

Neurath, Marie Auguste

von, 114 .

Nielsen, Hans, 21, 221,

259.

Noldan, Svend, 144n, 291.

Norkus, Herbert, 52n.

Nosferatu, ver Nosferatu,

eine Symphonie des

Grauens.

Nosferatu, eine Symphonie

des Grauens (1922), 99.

NS-Frauenschaft, 13, 111n,

$115 n$.

NSDAP, 13, 49n, 61n, 63n,

177, 187, 189, 198, 240, 275.

O

Ohm Krüger (1941), 32n,

52n, 215, 217, 291.

OKW (Oberkommando der

Wehrmacht), 13, 143n.

Opfergang (1944), 49n, 292.

Oppenheimer, Joseph Süß,

45-6.

Ouro, ver Gold (1934).

$\mathbf{P}$

Pabst, Georg Wilhelm,

53n, 243, 278, 291-2.

Paracelsus (1943), 53n, 278,

292.

Partido Nacional

Socialista dos

Trabalhadores Alemães, ver NSDAP.

Paulo de Tarso, 56.

Pecado de amor, ver Heimat

(1938).

Pettersson E Bendel (1933),

54n.

PKs (Propaganda

Kompanien), 13, 143n.

Poe, Edgar Alan, 93n.

Pommer, Erich, 96.

Powell, Michael, 159.

Power (1934), ver Jew Süss.

Prädikat, 15, 28n, 106, 223.

Prag-Film, 27n.

Premiere (1937), 119, 210.

Première, ver Premiere

(1937).

Prinz, Joachim, 41.

Propp, Vladimir, 98n.

$\mathbf{R}$

Rabenalt, Arthur-Maria,

52n, 116n, 291.

Raposa azul, $A$, ver

Blaufuchs, Der (1939).

Raymond, Ernest, 213.

Rebecca (1940), 214.

Rebecca, a mulher

inesquecível, ver Rebecca

(1940).

Recomeça a vida, ver $\mathrm{Zu}$

neuen Ufern (1937).

Reich, Wilhelm, 179, 216.

Reichsfilmkammer (Câmara

de Filmes do Reich), 15,

27.

Reichsministerium für

Volksaufklärung und

Propaganda, ver RMVP.

Remarque, Eric Maria,

187.

Rhodes, Cecil, 209.

Ribbentrop, Annelies von,

114.

Ribbentrop, Joachim von,

216n.

Riefenstahl, Leni, 48, 151n.

Rist, Sepp, 222.

Rittau, Günther, 254, 291.

Ritter, Karl, 139-40, 155n,

216, 254, 290-2.

RMVP (Reichsministerium

für Volksaufklärung und

Propaganda; Ministério do

Reich para Esclarecimento

Popular e Propaganda), 
15, 27, 29, 40, 48, 126, 143n, 159, 163n, 214, 223, 264n, 270, 275.

Robert Koch, ver Robert Koch, der Bekämpfer des Todes (1939).

Robert Koch, der Bekämpfer des Todes (1939), 52n, 290.

Robert und Bertran (1939),

54n, 290.

Robertson, Morgan, 212.

Rökk, Marika 120, 126,

155n, 289.

Romanze in Moll (1944), 116n, 292.

Rommel, Erwin, 163, 265n. Rothschilds Aktien auf Waterloo, Die (1940), 169, 215, 291, 218.

Roudinesco, Elisabeth, 180n.

Rühmann, Heinz, 35, 126, 199, 201, 284.

\section{$\mathrm{S}$}

SA Mann Brand (1933), 276, 289.

Sachsenhhausen, 181n.

Sadoul, George, 48.

Santa Joanna D'Arc, ver Mädchen Johanna, Das (1935).

Saved from the Titanic (1912), 213.

Scharf, Werner, 162, 220.

Scheu, Just, 220.

Schlageter (1933), 48n.

Schlageter, Albert Leo, $48 \mathrm{n}$.

Schmitt, Carl, 60n, 61n, 240-1.

Schmitz, Sybille, 21, 126, 220, 224, 226, 243-5.

Schneider, Magda, 126.

Scholtz-Klink, Gertrud, $115 n$.

Schönböck, Karl, 21, 220, 233, 234.

Schönhals, Albrecht, 79n. Schönnerer, Georg von, $52 n$.

Schwarz, Hanns, 201.

Schwarz Jr., Hans, 107.

Sehnsucht der Veronika

Voss, Die (1981), 244.

Seitz, Franz, 276, 289.
Selznick, David O., 214.

Selpin, Herbert, 21, 39,

52n, 53n, 201, 214-5, 217,

224, 226, 228n, 244, 246,

278, 289-92

Shelley, Mary, 93n.

Sherlock Holmes, ver Mann, der Sherlock Holmes war,

Der (1937).

Shirer, Willian A., 112.

Sieg in Western (1941), 144, 291.

Sierk, Detlef, 119-20, 120n, 132n, 289-90.

Simsom, Marianne, 19,

197, 206.

Simpson, Wallis, 216n.

Slezak, Leo, 19, 162, 205.

So endete eine Liebe (1934),

280, 289.

Söderbaum, Kristina, 19,

$44,47,49,75,78,81-2,122$,

126, 273.

Sontag, Susan, 179-80.

Sovexport-Film, 225.

Speelmans, Hermann, 161.

Speer, Albert, 112, 239,

274.

Spiegel des Lebens (1940),

280, 291.

Spoerl, Heinrich, 283, 292.

Staal, Viktor, 19, 107, 138,

155.

Steinhoff, Hans, 30n, 32n, 52n, 53n, 101, 215, 244, 272n, 278, 289-91.

Stevenson, Robert Louis,

93n.

Stoker, Bram, 93n.

Stolz, Hilde von, 162.

Streicher, Julius, 77, 83.

Stukas (1941), 139, 254,

291.

Stürmer, Der, 77.

\section{$\mathrm{T}$}

Tagebüch einer Verlorenen (1929), 243.

Tanz auf dem Vulkan, Der (1938), 244, 290.

Terra Filmkunst, 19n, 40.

Thief of Bagdad, The (1941), 159.

Thiele, Charlotte, 21, 220, 233, 234.

Thiemann, Friedrich, 48n.
Titanic (1943), 9-10, 21, 39, 221-67, 273, 292.

Titanic Disaster, 212.

Tobis Filmkunst, 21, 27n, 214, 292.

Tobis Wochenshau, 143n. Todorov, Tzvetan, 174, 193-4, 196.

Tourjansky, Viktor, 119, 282, 290.

Trenck, der Pandur (1940), 201, 246, 291.

Trenker, Luis, 169n, 227n, 278, 289

Tschechowa, Olga, 115n. Tunnel, Der (1933), 252, 289.

U

U-Boote westwärts (1941), 254, 291.

Über alles in der Welt

(1941), 139, 291.

Überkonfessionalismus, 15,

62.

Ucicky, Gustav, 53n, 170n, 215, 280-1, 290-1.

UFA, 15, 27n, 106, 119,

129, 164, 270.

UFI (UFI-Film GmbH),

$27 \mathrm{n}$.

Ufa-Tonwoche, 143n.

Ulrich, Luise, 126.

Unsterbliche Herz, Das

(1939), 49n, 52n, 290.

Unter dem Brücken (1945),

116n, 292.

V

Valsa do adeus, $A$, ver Abscheidswalzer (1934). Vampiro, O, ver Vampyr (1932).

Vampyr (1932), 243.

Verlorene Sohn, Der (1935),

169n, 227n, 289.

Verräter (1936), 216, 289.

Verwehte Spuren (1938),

81n, 227n, 290.

Vida de Emile Zola, A, ver

Life of Emile Zola, The

(1937).

Vier Gesellen, Die (1938),

108n, 290.

Voeglin, Eric, 61n. 
W

Wagner, Richard, 28.

Wandering Jew, The (1933),

46.

Walter Lord, $214 \mathrm{n}$.

Wartan, Aruth, 221.

Waschneck, Erich, 169,

215, 291.

Wasser für Canitoga (1939),

278, 290.

Wegener, Paul, 271-2.

Weiser, Grete, 107.

Weissner, Hilde, 215n.

Welzel, Heinz, 242.
Wen die Götter Lieben

(1942), 53n, 292.

Werker, Alfred L., 46.

Werner, Ilse, 19, 126, 162

197.

Wernicke, Otto, 221.

Wessel, Horst, 52n.

Wessely, Paula, 280.

Wenzler, Franz, 30n, 52n,

289.

White Star Line, 213-4.

Wien, 1910, 27n.

Wien-Film, 27n.

Wiene, Robert, 96.
Wilde, Oscar, 93n.

Wochenschau, ver Deutsche

Wochenschau.

Wunschkonzert (1940), 108, 116n, 151n, 232, 291.

Wysbar, Franz, 244, 289.

$\mathbf{Z}$

Zerlett, Hans Heinz, 54n,

290.

Zerlett-Olfenius, Walter, 215, 219, 224, 226n, 228.

Zu neuen Ufern (1937), 119, 132n, 134n, 155n, 290.

Zuinglio, Ulric, 57 